Universidad deValladolid

PROGRAMA DE DOCTORADO

EN INGENIERÍA QUÍMICA Y AMBIENTAL

TESIS DOCTORAL:

\title{
DIRECT ULTRAFILTRATION WITH MEMBRANES APPLIED TO THE CARBON RECOVERY FROM MUNICIPAL WASTEWATER
}

Presentada por Thiago Antonio do Nascimento

para optar al grado de

Doctor por la Universidad de Valladolid

Dirigida por:

Dra. María del Mar Peña Miranda 



\section{AGRADECIMIENTOS}

En primer lugar, agradecer profundamente a mi tutora de tesis María del Mar Peña Miranda por el inmenso apoyo, paciencia, resiliencia y mucho ánimo a lo largo de los últimos ocho años desde que llegué a España para acabar la carrera. Gracias por mostrarme que por más dura que sea la investigación, nada es imposible y que todo puede ser encarado de una forma bonita.

Agradecer a los amigos de la Facultad de Ciencias, que pasados tantos años ya no son colegas de trabajo sino fueron y son parte de mi vida. A los técnicos Aracely, Dani, Beatriz, Mónica, Enrique. A los amigos que, así como yo, se aventuraron y se aventuran en el maravilloso mundo de la investigación, Roberto, Jaime, João, Marta, leva, Fanny, Yadira, David y tantos otros. A los profesores del Departamento de Ingeniería Química y Tecnología del Medio Ambiente que siempre he mirado con admiración, en especial a Fernando Polanco, Pedro Encina, Silvia Bolado, María Polanco, Fidel Chaín, Rafa Mato y Raúl Muñoz.

A mis queridos amigos que han estado conmigo, de cerca o desde el otro lado del Atlántico, a lo largo de estos últimos años y que son mi inagotable fuente de energía. Isabela, Renato, Victor, Manuela, Rebeca, Anderson, Ivanilson, Juliana, Poliana: igracias por los increíbles momentos de procrastinación!

A María Alice y Angeles P. Palha por sentaren las bases de esa larga jornada.

A mi querida madrina Odenilda de quien siempre aprendo lecciones para toda la vida y es el ejemplo de persona que quiero ser de mayor. Muito obrigado!

Por fin, a la persona que, antes mismo que yo supiera lo que era una universidad, siempre decía: “un día, mi hijo será un doctor”. Obrigado mainha!!

Gracias a Dios por conducir mi vida de manera grandiosa.

"En la vastitud del espacio y en la inmensidad del tiempo mi, alegría es compartir un planeta y una época con vosotros"

Carl Sagan (adaptado). 

A la persona que siempre supo que un día aquí yo llegaría.

A mi madre Maria Elizabete do Nascimento (in memorian). 



\section{TABLE OF CONTENTS}

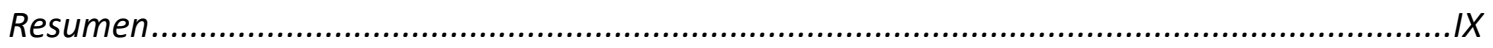

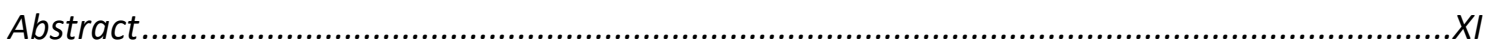

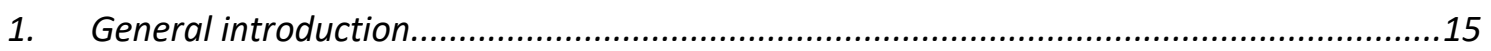

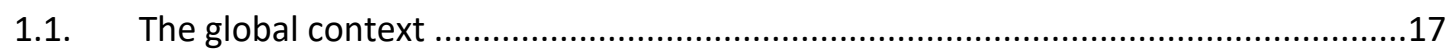

1.2. The energy consumption by current conventional wastewater treatment plants....18

1.3. The potential carbon recovery from municipal wastewater treatment plants .........21

1.4. The alternatives for carbon capture and role of direct membrane filtration .............22

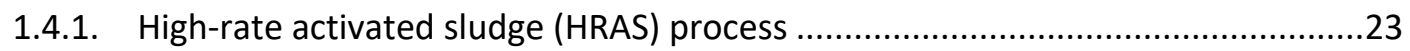

1.4.2. Chemically enhanced primary treatment (CEPT) process .....................................24

1.4.3. Membrane-based treatment process................................................................25

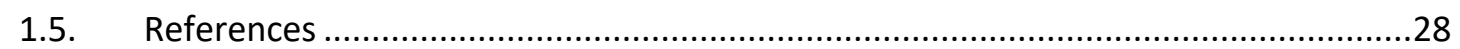

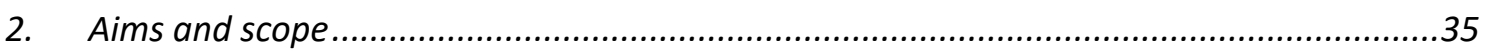

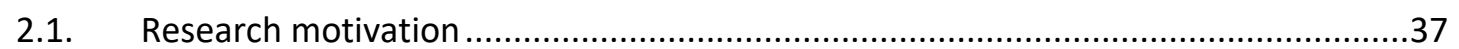

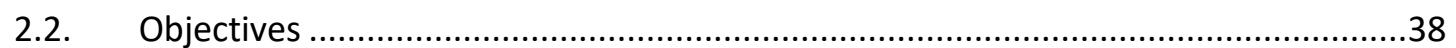

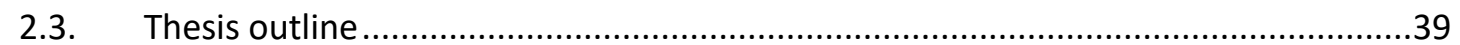

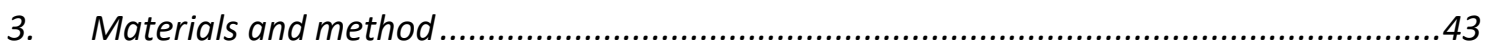

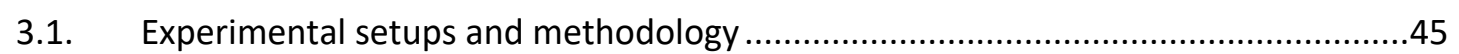

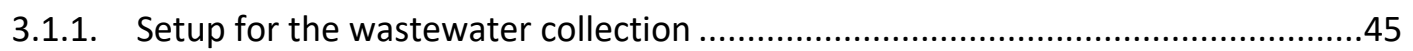

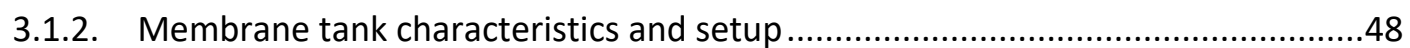

3.1.3. Membrane module characteristics and setup ..................................................52

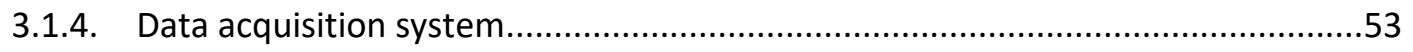

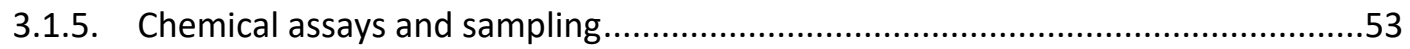

3.1.6. Biochemical methane potential assays (BMPs) ....................................................53

3.1.7. Out of place setup for the membrane cleanings .................................................54

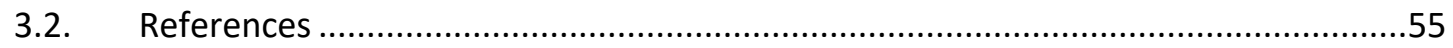

4. Membrane-based technologies for the up-concentration of municipal wastewater: $A$

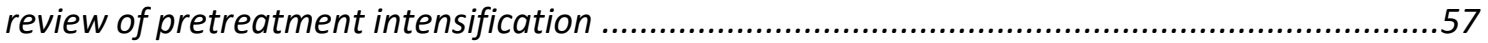

5. Improvement of municipal wastewater pretreatment by direct membrane filtration .....107

6. Continuous municipal wastewater up-concentration by direct membrane filtration, considering the effect of intermittent gas scouring and threshold flux determination 
7. Control strategies for the long-term operations of direct membrane filtration of municipal wastewater

8. Anaerobic submerged membrane bioreactor (AnSMBR) treating municipal wastewater at ambient temperature: operation and potential use for agricultural irrigation..... 203

9. Conclusions. 235

9.1. Specific conclusions .237

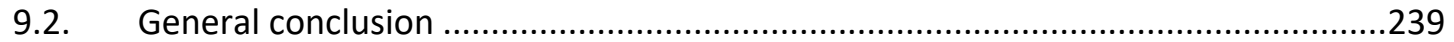

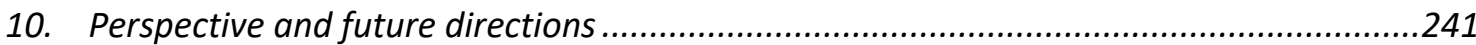

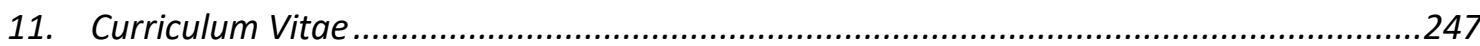




\section{restusnes]}

Las estaciones depuradoras de aguas residuales (EDARs) son consideradas de importancia relevante para la segura continuidad del ciclo del agua con impacto directo en el medio ambiente y en las actividades humanas. En este sentido, la demanda global de tecnologías cada vez más sostenibles debe incentivar el sector de tratamiento de aguas residuales urbanas a mejorar la recuperación de carbono y nutrientes combinado con una alta calidad del agua tratada. En este contexto, la filtración directa con membranas aplicada a la recuperación del contenido de materia orgánica de las aguas residuales municipales, junto a la cada vez mayor robustez y experiencia de las membranas de ultrafiltración surge como un proceso robusto, flexible y fiable. La materia orgánica contenida en las aguas residuales municipales puede ser convertida a biogás con potencial de cambiar el actual escenario de las EDARs de grandes consumidoras de energía a productoras de energía.

En la presente tesis, la viabilidad de la filtración directa con membranas ha sido estudiada realizando tanto experimentos a corto plazo como a largo plazo, considerando que se trata de un proceso relativamente novedoso en el que el ensuciamiento de la membrana presenta la mayor dificultad. Se ha operado en dos depuradoras distintas y a escala piloto. Y se han utilizado técnicas sencillas y de bajo coste como control del ensuciamiento de la membrana. Los resultados obtenidos muestran que se pueden obtener entre 10 y $45 \mathrm{~g} / \mathrm{L}$ en concentraciones de sólidos, y entre 11 y $54 \mathrm{~g} / \mathrm{L}$ en DQO que puede ser llevados directamente a digestión anaerobia, aprovechando de esta forma la mayor parte del contenido de la materia orgánica del agua residual municipal. Mientras que la presión transmembrana de filtración se mantiene por debajo de los 400 mbar a través del empleo de algunas 


\section{rRestusnen}

técnicas combinadas como son agitación con gas, contralavado y purga de los sólidos concentrados en el tanque de membrana.

Esa tesis contribuye en un pequeño grado al desarrollo del conocimiento aportando al campo de los procesos de tratamiento de aguas residuales municipales una tecnología que en un futuro puede ser sostenible. 


\section{Alostreget}

Wastewater treatment plants (WWTPs) are considered with relevant importance for the safe continuity of the water cycle, with a direct impact on the environment and human activities. In this sense, the increasing global demand for sustainable technologies should encourage the urban wastewater treatment sector to improve carbon and nutrient recovery combined with the high quality of treated water. In this context, direct filtration with membranes applied to the recovery of organic material from municipal wastewater, together with the ever-greater robustness and experience of ultrafiltration membranes, appears as a robust, flexible and reliable process. The organic material embedded in municipal wastewater could be converted into biogas with the potential to change the current scenario of WWTPs from huge energy consumers to energy producers.

In the present thesis, the feasibility of direct filtration with membranes has been studied by carrying out both short and long-term experiments, considering that it is a relatively new process in which the membrane fouling is the greatest operational difficulty. The operations have been developed in two different WWTPs. Low cost and common techniques have been used to control membrane fouling. The results showed that between 10 and $45 \mathrm{~g} / \mathrm{L}$ in total solids concentrations, and between 11 and $54 \mathrm{~g} / \mathrm{L}$ in chemical oxygen demand can be conveyed directly to anaerobic digestion, thereby up taking a major part of the organic material from municipal wastewater, whereas the transmembrane pressures of filtration are maintained under 400 mbar by applying combined techniques such as gas agitation, permeate backwash and purging of solids concentrated in the membrane tank. 


\section{Alostregot}

This thesis contributes in a small extent to the development of knowledge by providing to the field of municipal wastewater treatment processes a novel technology that in the future could be sustainable. 



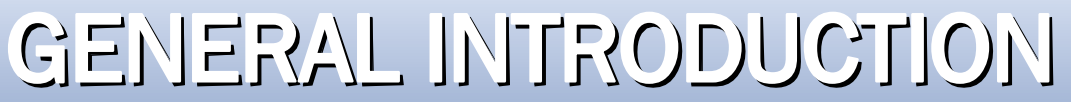

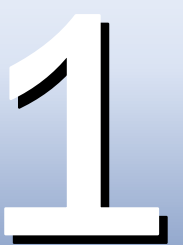

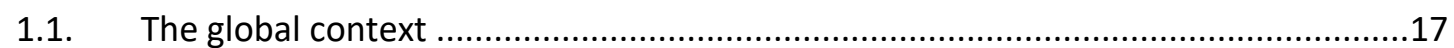

1.2. The energy consumption by current conventional wastewater treatment plants....18

1.3. The potential carbon recovery from municipal wastewater treatment plants .........21

1.4. The alternatives for carbon capture and role of direct membrane filtration ............22

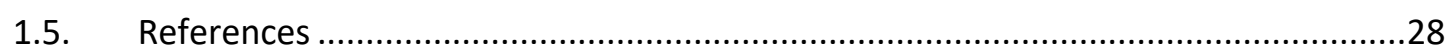





\subsection{The global context}

Urban wastewater treatment is of utmost importance for guaranteeing adequate levels of human being quality of life and dignity. The adequate addressing of wastewater leads the society to better health conditions, to protect the environment against pollution and to provide economic savings and profits. In 2015 , the United Nations established the 2030 Agenda for the Sustainable Development [1] in which 17 sustainable development goals (SDGs) are urged to be achieved by 2030. The current conditions of water sources and sanitation worldwide demand the member states to accomplish with the $6^{\text {th }}$ goal: ensure availability and sustainable management of water and sanitation for all. Far from being achieved by most of the countries, the sanitation conditions worldwide are of great concern for both rich, and especially poor and middle-income economies. It is estimated that the wastewaters produced by over 4.5 billion people around the world are not efficiently treated and cause hazardous consequences to the environment and human themselves [2]. Furthermore, the global population increase associated with the climate change have been put pressure over the conventional processes for the treatment of urban wastewaters. Municipal wastewater treatment plants (WWTPs) are expected to suffer adaptations in order to face the climate changes impacts, such as temperature variations, precipitation regime, heat waves, increasing snowfalls, variations of flowrate wastewater [3,4]; and the population growth and anthropogenic activities impacts, such as the poorest conditions of influent wastewater and flowrate increase [5]. These changes on the quantity and quality of inlet municipal wastewaters are reflected mainly as microbial and chemical changes on the current characteristics of wastewater and will demand higher energy consumption in order to provide an outlet wastewater with high purity degree. Besides, new contaminant agents will boost the current treatment plants to adapt their processes in order to remove unprecedented 
microbial contents, like the coronavirus SARS-CoV-2 that causes the Coronavirus disease 2019 (COVID-19) [6,7], and new chemical contents, like the contaminants of emergent concerns (CECs) [8] and pharmaceutical and personal care products (PPCPs) [9].

In light of this, smart solutions and refined technologies for municipal wastewater treatment are underway by researchers in many institutions worldwide and these advances, always as possible, should have as common targets the capacity of delivering a high-quality wastewater that fits with stringent legislations, the minimization of generated wastes, the minimal energy consumption, and the recovery of valuable products. In such a context, membrane-based processes are highlighted as being a promise for future as smart, adaptable and compact technologies for the municipal wastewater treatment. Among these technologies, the so-called direct membrane filtration (DMF) stands out as a simple and robust one for fulfilling technical and economic aspects and for accomplishing with sustainable criteria as a potential energy self-sufficient process.

\subsection{The energy consumption by current conventional wastewater treatment plants}

A wide range of processes for the municipal wastewater treatment have been developed with the basic aim of delivering treated water that accomplishes with local and global legislations. These projects, however, paid not enough attention to the energy consumption and to the rise of energy demanding over the years $[10,11]$. The energy required for the WWTPs may comprise average slices between $1 \%$ to $4 \%$ of the total electric energy output of a country [11-15] with specific power consumption ranging from 0.2 to $2.1 \mathrm{kWh} / \mathrm{m}^{3}$, in terms of treated wastewater [16-20]. On another hand, it is widely reported that between 24 and $60 \%$ of these energy consumptions are ascribed to the operating costs of a conventional WWTP, which is commonly 
composed of a preliminary stage (pumping of inlet wastewater, screening and grit removal), primary treatment (circular settling), secondary treatment (widely applied activated sludge (AS) with or without nutrients removal followed by a second circular settling for the separation of produced solids), tertiary treatment (UV disinfection, equipment for dosage of reagents, etc.) and sludge treatment (thickening, anaerobic digestion, sludge dewatering, etc.) [21-24]. The AS process is a high energy-intensive process because of the aeration provided in the oxidation basins [22]. The energy consumed in this stage is a function of many variables, especially the plant size, quantity of organics to be removed and type of bioreactor aeration [25]. Nonetheless, on average, the energy consumption is between $50 \%$ and $60 \%$ of the entire AS process. Fig. 1 [21] depicted the proportion of the energy consumption for each stage of a conventional AS treatment plant.

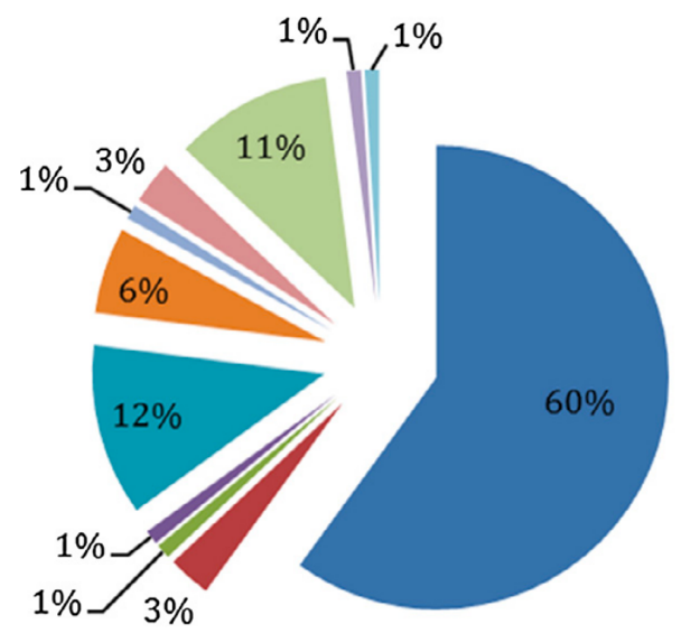

$$
\begin{aligned}
& \text { n Aeration } \\
& \text { n Clarifiers } \\
& \text { arit } \\
& \text { - Screens } \\
& \text { - Wastwater Pumping } \\
& \text { - Lighting and Bulidings } \\
& \text { a Chlorination } \\
& \text { a Belt Press } \\
& \text { Anaerobic Digestion } \\
& \text { a Thickening } \\
& \text { घ Return Sludge Pumping }
\end{aligned}
$$

Figure 1.1 - Proportion of energy consumption for different stages of a conventional activated sludge process [21].

The range of specific energy demanded by treatment stage is relatively wide. In any case, independently of the plant configuration and facilities adopted, energy usage is often lower for the preliminary and primary treatments and higher for the secondary and tertiary treatments. For the preliminary and primary treatments, the 
consumption is situated between $0.02-0.37 \mathrm{kWh} / \mathrm{m}^{3}$ with most electrical expenditure associated to the pumping requirements. For the secondary treatment, in turn, the amount of energy ranges between 0.14 and $1.89 \mathrm{kWh} / \mathrm{m}^{3}$, considering only the AS processes. The energy consumed by the tertiary treatment is ranged between 0.045 and $3.74 \mathrm{kWh} / \mathrm{m}^{3}$, but with the literature reporting $0.4 \mathrm{kWh} / \mathrm{m}^{3}$ as a predominant average value. Finally, the sludge line participates with a 0.015 to 0.027 $\mathrm{kWh} / \mathrm{m}^{3}$ with major consumption associated to the sludge dewatering due to the mechanical centrifugation $[21,22,24]$.

Especially when associated with stringent tertiary treatments, the WWTP with AS process are huge energy consumer industries and, directly and indirectly, these plants are responsible for important amounts of greenhouse gas emissions. The interrelationship between water and energy has become of major interest in the last decades and the hot topic "water-energy nexus" has emerged as a comprehensive approach to understand the environmental impact associated to the wastewater treatment $[13,19,26]$. The carbon footprint [27] contribution from conventional WWTPs, in terms of kilograms of carbon dioxide per cubic meter of treated water $\left(\mathrm{kgCO}_{2} / \mathrm{m}^{3}\right)$, is estimated between $0.03-3.04 \mathrm{kgCO}_{2} / \mathrm{m}^{3}$, considering only the energy consumption $[19,26,28-30]$, not to mention the biogenic emissions, that are responsible for the direct release of greenhouse gases into the environment through biological processes. The direct $\mathrm{CO}_{2}$ released to the atmosphere through the biological processes are reported with values between $1.5 \times 10^{-3}-4.9 \times 10^{-1}$ $\mathrm{kgCO}_{2} / \mathrm{m}^{3}$, meanwhile $\mathrm{CH}_{4}$ and $\mathrm{N}_{2} \mathrm{O}$ emissions (gases with 28 and 265 times, respectively, higher potential to the global warming than $\mathrm{CO}_{2}$ over a 100 -year horizon [31] ), appeared between $2.2 \times 10^{-5}$ and $1 \times 10^{-1} \mathrm{kgCH}_{4} / \mathrm{m}^{3}$, and $6 \times 10^{-6}$ and $4 \times 10^{-}$ $4 \mathrm{kgN}_{2} \mathrm{O} / \mathrm{m}^{3}$, respectively [29,32-35]. Even though the WWTPs are extremely important to the water cycle equilibrium in the environment, most of the plants 
strongly contribute to the climate change negatively and a shift toward better practices and novel and enhanced technologies is urgent.

\subsection{The potential carbon recovery from municipal wastewater treatment plants}

Even though the current wastewater facilities need improvement in terms of energy consumption, the energy content embedded in the municipal wastewater as organic carbon, commonly referred as chemical oxygen demand (COD), has a great potential to be harvested and used for energy production, thus further contributing to neutral or negative carbon footprint. Empirical studies estimated that the chemical energy in the municipal wastewater is between 14.7 and $28.7 \mathrm{~kJ} / \mathrm{gCOD}$, depending on the particular sampling and storage procedures [36,37]. Even considering the thermodynamic approach and the stoichiometry for the COD oxidation, this energy content is a standard $13.9 \mathrm{~kJ} / \mathrm{gCOD}[38,39]$. If this energy potential was captured for producing biogas through anaerobic digestors, a net energy production would cover partially or completely the current power demand or even become power supplies for external facilities, as widely reported [40-43]. Nevertheless, the diluted characteristic, (339 - $508 \mathrm{mg} / \mathrm{L}$ low-medium strength wastewaters [22]) and the usually low temperature (about $15^{\circ} \mathrm{C}$ [22]) of municipal wastewaters, especially in cold climate countries, hinders the efficiency of conventional anaerobic treatments for the feasible recovery and direct biological conversion into methane-rich biogas. Moreover, it is estimated that the particulate COD ( $\mathrm{CCOD}$ ) content of municipal wastewater accounts for $50-65 \%$ of total COD [44-46], which means that an important rate limitation for the hydrolysis step for both aerobic or anaerobic biological processes takes place [47-49]. In anaerobic digestion, when combined with low temperature and high particulate fractions of COD, the metabolic activity of mesophilic anaerobic methanogenic bacteria is negatively influenced, as reported by 
the literature [50]. Besides, under low temperature, usually the anaerobic treatments faces the necessity of working with low rate of substrate utilization, reduced specific microbial growth, and increase in methane solubilization [51]. Therefore, since the primary intention is to recover the maximum organic content from wastewater in order to produce biogas, the mesophilic anaerobic digestion is still the most viable technology with most energy self-sufficient WWTPs having this technology for heating and electricity generation [21]. Yet, until now, the challenge remained in the development of a feasible technology capable of separating and concentrating the particulate matter from the diluted and cold primary wastewaters in a small volume to reduce energy expenditure with heating and to allow for treating under moderate temperatures.

\subsection{The alternatives for carbon capture and role of direct membrane filtration}

The main idea behind the carbon capture is based on the separation of the wastewater treatment in 2 stages, known as A-B process, in which the organic matter recovery is maximized prior to the biological processes and then conveyed for anaerobic digestion, as represented in Fig. 1.2a. This system configuration allows the methane production to offset the WWTP's energy consumption, as represented in Fig. 1.2b.
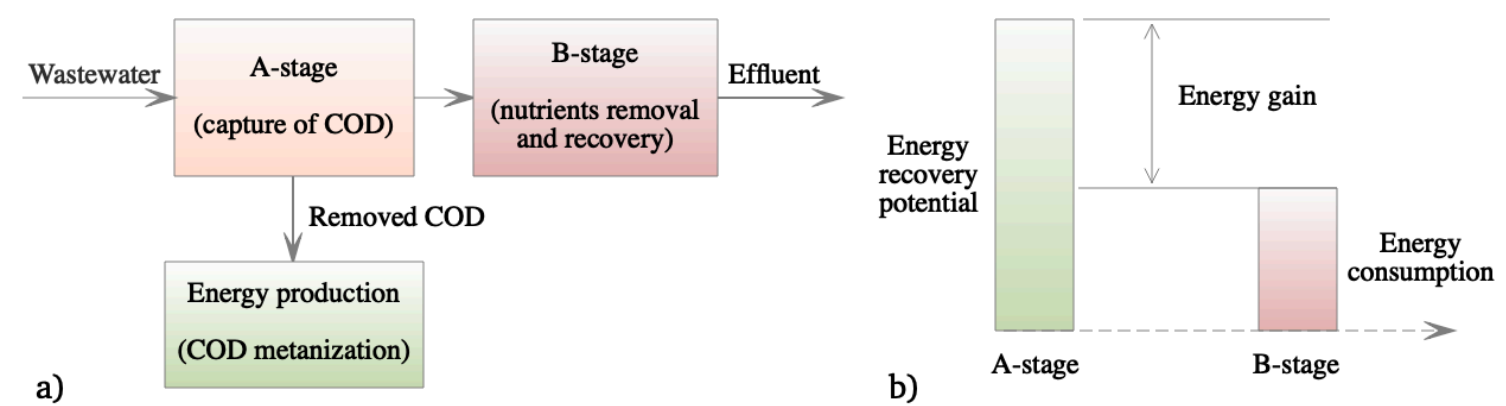

Figure 1.2 - General configuration for the A-B stage process (modified from the figures in [52]). 
Many technologies for the A-stage are being investigated for decades, but its widely application is still timid, mainly regarding to the operational costs, even though the carbon capture is highly increased in the A-stage, and nutrients recovery is made easier. Some technologies for COD capturing have received much attention in the last years with interesting results and publications, like high-rate activated sludge (HRAS) process, chemically enhanced primary (CEPT) process and membrane-based processes, like membrane bioreactor (MBR), dynamic membrane (DM), forward osmosis (FO) and direct membrane filtration (DMF) [52-54]. Fig. 1.3 presents a general diagram for the possible A-B stage treatments for the carbon capture and nutrients recovery.

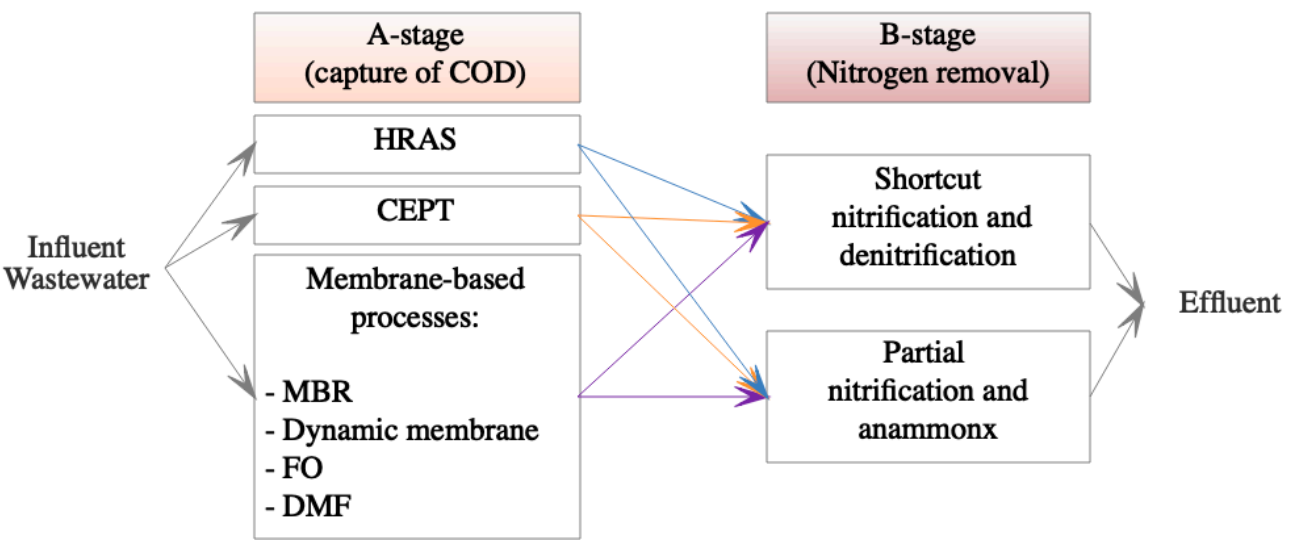

Figure 1.3 - Simplified representation of alternatives A-B treatment for carbon capture and nutrients removal

\subsubsection{High-rate activated sludge (HRAS) process}

The HRAS process relies in a modification of operating conditions of the conventional AS in order to exploit the carbon uptake and storage into the microbial cells, allied to the adsorption of particulate and colloidal compounds onto the subsequent formed bioflocs. These particles are then removed by a solid-liquid separation process and conveyed for anaerobic digestion. To avoid the carbon oxidation, the process operates with short hydraulic retention times (HRT), between 2 and 4 hours, short solid retention times (SRT), below 2 days, and high organic 
loading rates (OLR), of the order of 2 gBOD/g VSS/day [52,55]. Two configurations of HRAS stands out with good results and high rate of carbon removal: the adsorption/bio-oxidation process (A/B-process) and the contact stabilization (CS) process, both with removal efficiencies between 70 and $80 \%$ of total COD [53]. Despite the high carbon removal, oxygen supply remain a concern for the economics of the process, even though the oxygen consumption is reported to be up to $60 \%$ lower than the required for a conventional AS process [55] and the recoverable electrical energy may be significantly higher than the conventional AS process [54]. The nutrient removal is also a concern, since an adequate COD balance is needed for providing enough carbon for the nitrification/denitrification process in the B-stage, even though a partial nitrification and anammox system is also considered an option. A schematic representation of a general HRAS is presented in Fig. 1.4.

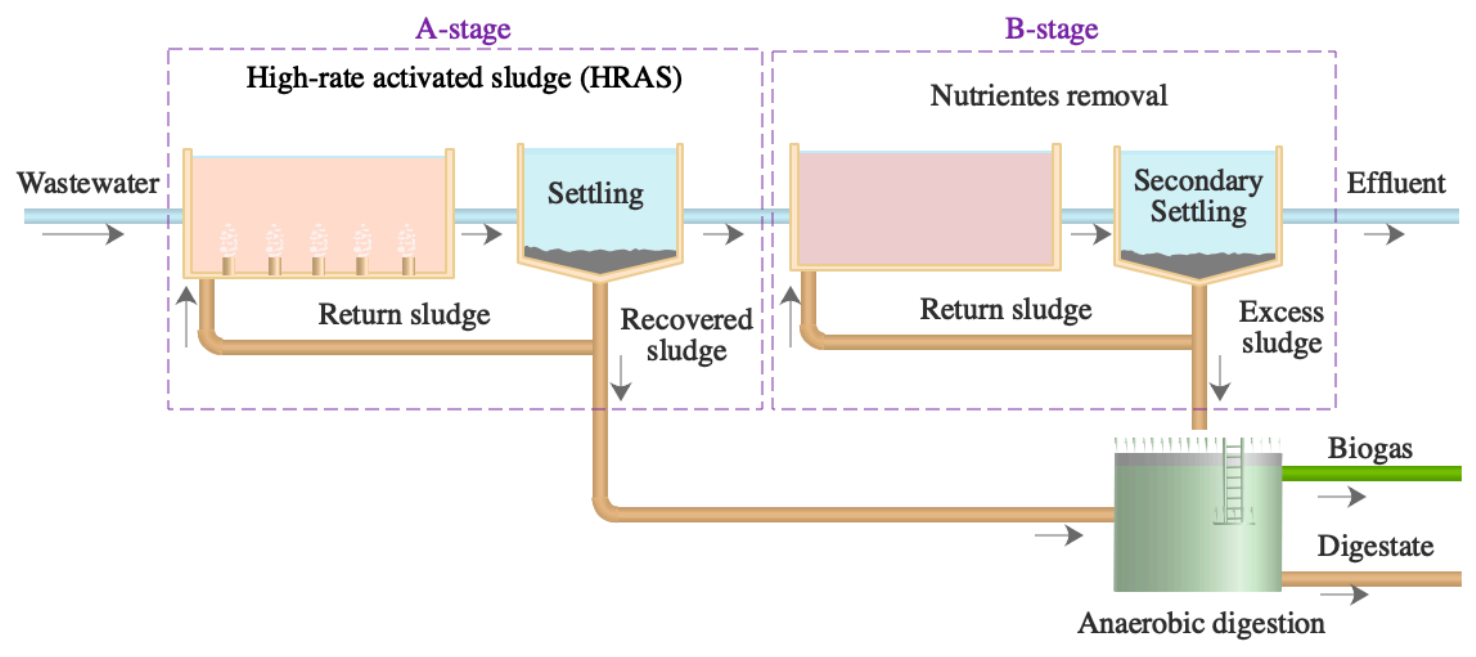

Figure 1.4 - Schematic representation of HRAS processes for carbon capture from municipal wastewater

\subsubsection{Chemically enhanced primary treatment (CEPT) process}

The CEPT process is based on the addition of chemicals in the influent wastewater in order to form larger flocs to be settled in a subsequent sedimentation. The efficiency of the treatment ranges from $40 \%$ to $80 \%$ in terms of removed COD especially for the particulate organic matter, since the coagulants were reported to 
have low effect over the soluble COD [53,54], which in contrast, play in favor of the nitrification/denitrification conventional process for nitrogen removal. The operating concerns of the CEPT process relies mainly on the types of chemicals and the energy requirements for mixing. The chosen additives for the flocculation process will determine the floc size, the amount of sludge produced, the settled sludge degradability and the costs associated to the chemicals purchasing, which is estimated in $0.1 € / \mathrm{m}^{3}$ [54]. Organic and inorganic chemicals can be applied for the particulate and colloidal matter flocculation, but the literature and most of the fullscale WWTPs with CEPT process is reported to make use of alum $\left(\mathrm{Al}_{2}\left(\mathrm{SO}_{4}\right)_{3}\right)$, ferric chloride $\left(\mathrm{FeCl}_{3}\right)$ and polyaluminum chloride (PACl), with this later being said as causes less sludge generation and no negative effect for the anaerobic digestion $[52,56]$. Fig. 1.5 shows a schematic representation of a basic CEPT process in a municipal WWTP.

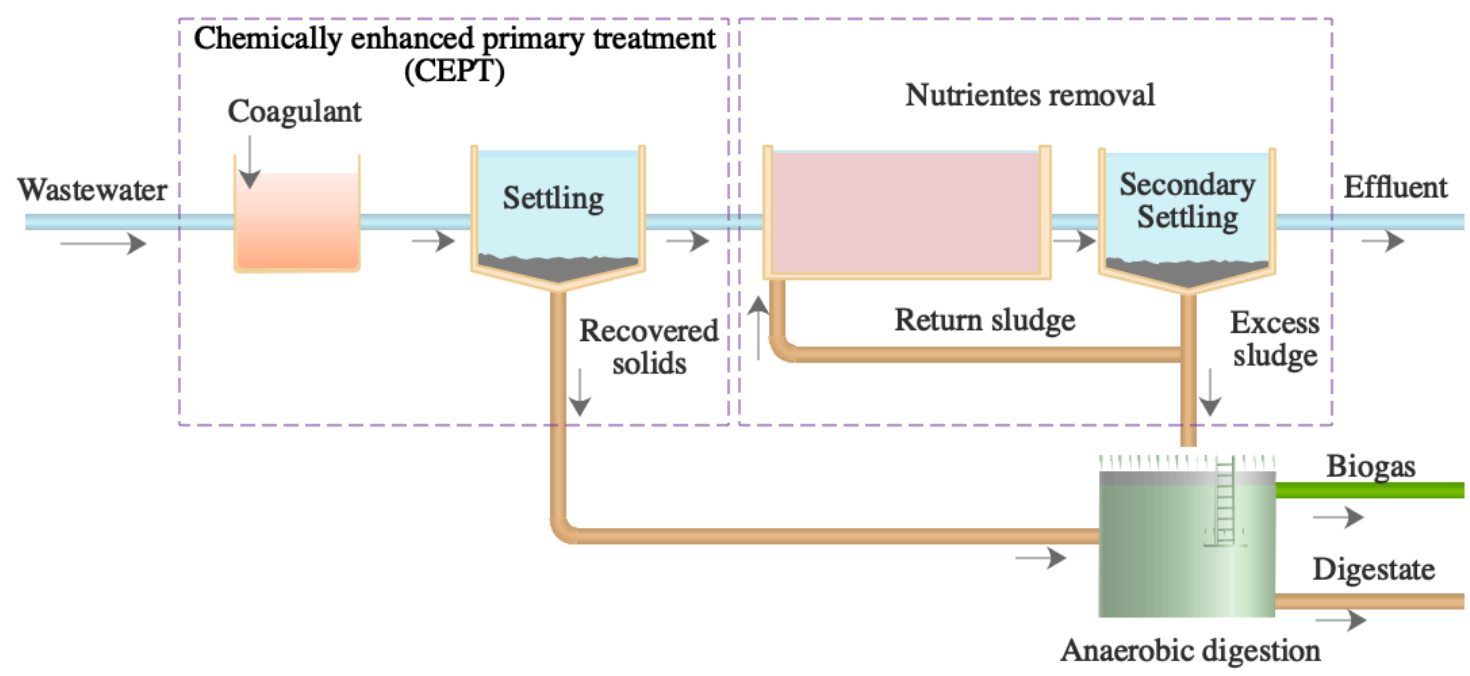

Figure 1.5 - Schematic representation of HRAS processes for carbon capture from municipal wastewater

\subsubsection{Membrane-based treatment process}

When it comes to removal capacity of particulate COD, and therefore higher potential of energy production, membrane-based processes appear as the most efficient and maybe reliable technology in terms of quality of produced water. By 
means of a physical barrier, a membrane, the particulate and most of colloidal matter is retained in one side, the retentate phase, and the liquid stream with soluble matter flows through the membrane to the other side, the permeate phase [57]. This uncomplicated yet useful process is applied for a very large variety of industries, such as food, medical, desalination, chemical, and especially water and wastewater treatments [58] where its potential for replacing the conventional AS process, as an A-stage, has been exponentially exploited in the last years [52,59-62]. A schematic representation of a membrane-based process for a wastewater treatment is shown in Fig. 1.6.

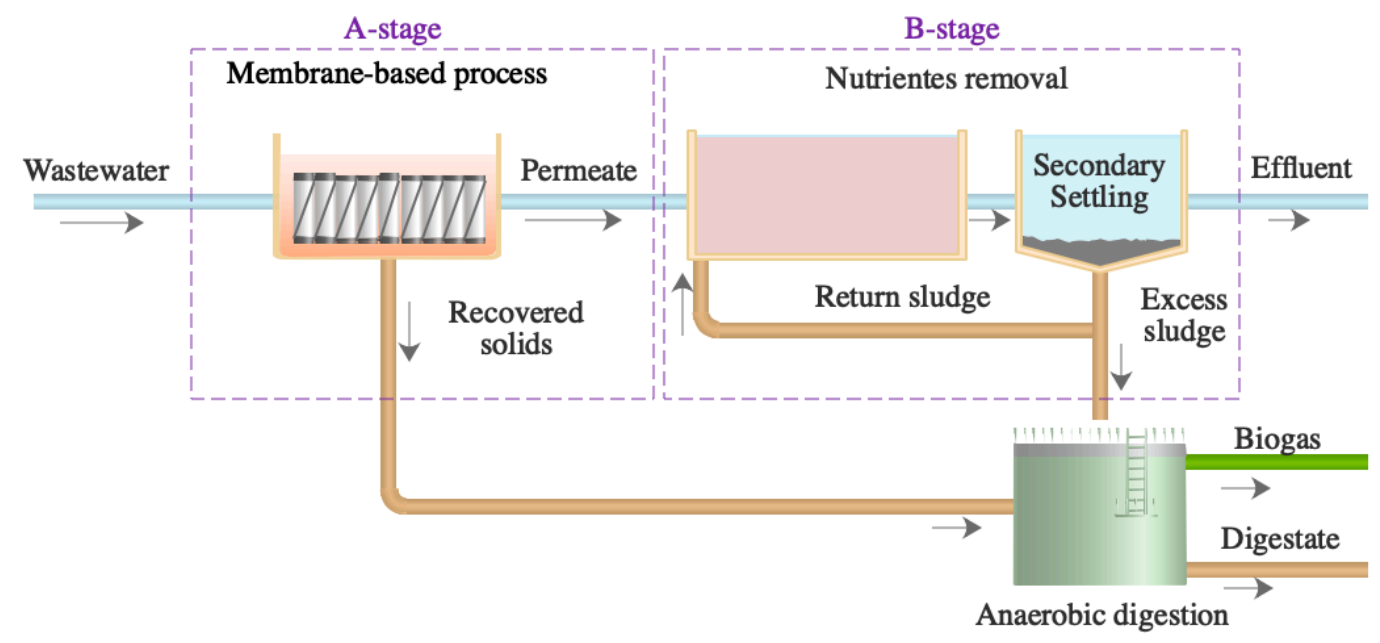

Figure 1.6 - Schematic representation of a membrane-based process for carbon capture from municipal wastewater

As a process for the wastewater treatment, the membrane bioreactor (MBR) [63] concept has been widely studied and applied on full-scale with important advances in membrane materials, system configurations, operating conditions and creative supplementary technologies and strategies to avoid the fouling formation, which still continues to be the major concern in the membrane-based processes [64]. The MBR advances were crucial for the understanding of the membrane filtration capacities, but in the aerobic membrane bioreactors (AeMBR) the aeration requirements for both biological oxidation and membrane agitation (as a strategy to 
avoid the fouling layer formation) is still a constraint. As shown in Fig. 1.7 [65], the energy consumption for the biological degradation + membrane scouring corresponds up to $60 \%$ of the energy requirements. The characteristics of the fouling layer is another concern, since the membrane modules are exposed to extracellular polymeric substances and soluble microbial products which difficult the antifouling techniques efficiency.

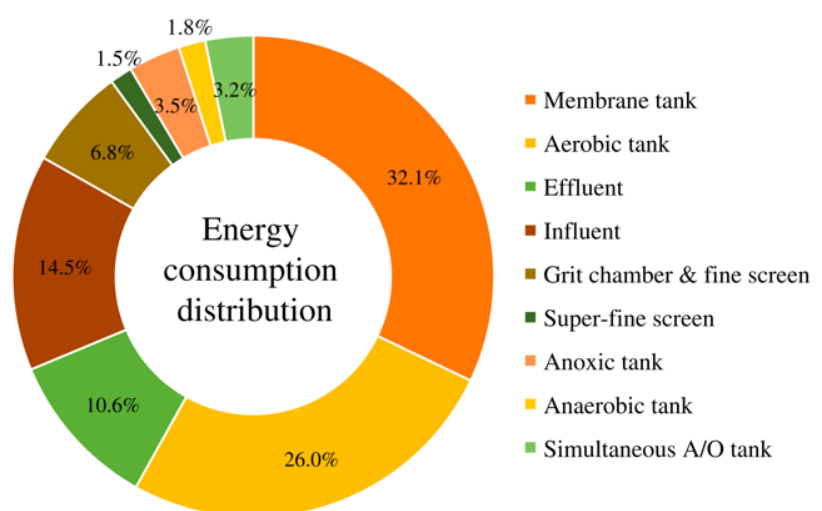

Figure 1.7 - Proportion of energy consumption in different stages of an aerobic MBR process [65].

The anaerobic membrane bioreactor (AnMBR) then emerged as an option against the aerobic necessities and gained attention due to the advantage of the coupled anaerobic digestion, thus prompting the energy production. Nevertheless, the high SRT induces the membrane fouling and the membrane lifespan, not to mention the hydrolysis limitation due to the temperature, and the leak of methane dissolved through the permeate, which could potentially contribute to greenhouse gas emissions [66-68].

The majority of the before mentioned concerns are due to the microbial activity combined to the membrane separation, both in the membrane tank/device. Therefore, a feasible option would decouple the carbon separation in a physical stage and the biological oxidation in a separated bioreactor, precisely an anaerobic digestor. In this case, the direct membrane filtration appears as a feasible option for overcoming this issue $[60,69,70]$. 
With this general framework, this work outlines the direct membrane filtration of municipal wastewater with emphasis on the operating conditions, techniques and procedures to minimize the fouling formation, efficiency of COD recovery, biodegradability of the recovered organic matter and energy balance. Chapter 4 introduces a detailed direct membrane filtration review with the main membranebased technologies considered up until now as options for being used as carbon capture processes in the municipal wastewater treatment plants.

\subsection{References}

[1] UN General Assembly, Transforming Our World: The 2030 Agenda for Sustainable Development, (2015). https://www.un.org/ga/search/view_doc.asp?symbol=A/RES/70/1\&Lang=E (accessed January 23, 2021).

[2] UNICEF, WHO, State of the World's Sanitation: An urgent call to transform sanitation for better health, environments, economies and societies, New York, 2020.

[3] M. Khalkhali, W. Mo, The energy implication of climate change on urban wastewater systems, J. Clean. Prod. 267 (2020) 121905. doi:10.1016/j.jclepro.2020.121905.

[4] F. Abdulla, S. Farahat, Impact of Climate Change on the Performance of Wastewater Treatment Plant: Case study Central Irbid WWTP (Jordan), Procedia Manuf. 44 (2020) 205-212. doi:10.1016/j.promfg.2020.02.223.

[5] G.Z. Teklehaimanot, I. Kamika, M.A.A. Coetzee, M.N.B. Momba, Population Growth and Its Impact on the Design Capacity and Performance of the Wastewater Treatment Plants in Sedibeng and Soshanguve, South Africa, Environ. Manage. 56 (2015) 984-997. doi:10.1007/s00267-015-0564-3.

[6] A. Bhatt, P. Arora, S.K. Prajapati, Occurrence, fates and potential treatment approaches for removal of viruses from wastewater: A review with emphasis on SARS-CoV-2, J. Environ. Chem. Eng. 8 (2020) 104429. doi:10.1016/j.jece.2020.104429.

[7] B. Saawarn, S. Hait, Occurrence, fate and removal of SARS-CoV-2 in wastewater: Current knowledge and future perspectives, J. Environ. Chem. Eng. 9 (2021) 104870. doi:10.1016/j.jece.2020.104870.

[8] A.I. Shah, M.U. Din Dar, R.A. Bhat, J.P. Singh, K. Singh, S.A. Bhat, Prospectives and challenges of wastewater treatment technologies to combat contaminants of emerging concerns, Ecol. Eng. 152 (2020) 105882. doi:10.1016/j.ecoleng.2020.105882.

[9] J. Wang, S. Wang, Removal of pharmaceuticals and personal care products (PPCPs) from wastewater: A review, J. Environ. Manage. 182 (2016) 620-640. doi:10.1016/j.jenvman.2016.07.049. 
[10] J. Rojas, T. Zhelev, Energy efficiency optimisation of wastewater treatment: Study of ATAD, Comput. Chem. Eng. 38 (2012) 52-63. doi:10.1016/j.compchemeng.2011.11.016.

[11] A. Majid, I. Cardenes, C. Zorn, T. Russell, K. Colquhoun, R. Bañares-Alcantara, J.W. Hall, An analysis of electricity consumption patterns in the water and wastewater sectors in South East England, UK, Water (Switzerland). 12 (2020) 1-17. doi:10.3390/w12010225.

[12] A.G. Capodaglio, G. Olsson, Energy issues in sustainable urban wastewater management: Use, demand reduction and recovery in the urban water cycle, Sustain. 12 (2020). doi:10.3390/su12010266.

[13] S. Nair, B. George, H.M. Malano, M. Arora, B. Nawarathna, Water-energy-greenhouse gas nexus of urban water systems: Review of concepts, state-of-art and methods, Resour. Conserv. Recycl. 89 (2014) 1-10. doi:10.1016/j.resconrec.2014.05.007.

[14] P.L. McCarty, J. Bae, J. Kim, Domestic wastewater treatment as a net energy producer-can this be achieved?, Environ. Sci. Technol. 45 (2011) 7100-7106. doi:10.1021/es2014264.

[15] International Energy Agency, Water Energy Nexus- Excerpt from the World Energy Outlook 2016, lea. 60. https://www.iea.org/publications/freepublications/publication/WorldEnergyOutlook2016Exc erptWaterEnergyNexus.pdf.

[16] D. Panepinto, S. Fiore, M. Zappone, G. Genon, L. Meucci, Evaluation of the energy efficiency of a large wastewater treatment plant in Italy, Appl. Energy. 161 (2016) 404-411. doi:10.1016/j.apenergy.2015.10.027.

[17] V.G. Gude, Energy and water autarky of wastewater treatment and power generation systems, Renew. Sustain. Energy Rev. 45 (2015) 52-68. doi:10.1016/j.rser.2015.01.055.

[18] Y. He, Y. Zhu, J. Chen, M. Huang, P. Wang, G. Wang, W. Zou, G. Zhou, Assessment of energy consumption of municipal wastewater treatment plants in China, J. Clean. Prod. 228 (2019) 399-404. doi:10.1016/j.jclepro.2019.04.320.

[19] Y. Gu, Y.N. Dong, H. Wang, A. Keller, J. Xu, T. Chiramba, F. Li, Quantification of the water, energy and carbon footprints of wastewater treatment plants in China considering a water-energy nexus perspective, Ecol. Indic. 60 (2016) 402-409. doi:10.1016/j.ecolind.2015.07.012.

[20] L. Luo, M. Dzakpasu, B. Yang, W. Zhang, Y. Yang, X.C. Wang, A novel index of total oxygen demand for the comprehensive evaluation of energy consumption for urban wastewater treatment, Appl. Energy. 236 (2019) 253-261. doi:10.1016/j.apenergy.2018.11.101.

[21] Y. Gu, Y. Li, X. Li, P. Luo, H. Wang, Z.P. Robinson, X. Wang, J. Wu, F. Li, The feasibility and challenges of energy self-sufficient wastewater treatment plants, Appl. Energy. 204 (2017) 1463-1475. doi:10.1016/j.apenergy.2017.02.069.

[22] W. Metcalf, C. Eddy, Wastewater engineering: treatment and resource recovery, 5th ed., McGraw-Hill Education, New York, 2014.

[23] P. Foladori, M. Vaccari, F. Vitali, Energy audit in small wastewater treatment plants: Methodology, energy consumption indicators, and lessons learned, Water Sci. Technol. 72 (2015) 1007-1015. doi:10.2166/wst.2015.306.

[24] S. Longo, B.M. d'Antoni, M. Bongards, A. Chaparro, A. Cronrath, F. Fatone, J.M. Lema, M. Mauricio-Iglesias, A. Soares, A. Hospido, Monitoring and diagnosis of energy consumption in 
wastewater treatment plants. A state of the art and proposals for improvement, Appl. Energy. 179 (2016) 1251-1268. doi:10.1016/j.apenergy.2016.07.043.

[25] F. Hernández-Sancho, M. Molinos-Senante, R. Sala-Garrido, Energy efficiency in Spanish wastewater treatment plants: A non-radial DEA approach, Sci. Total Environ. 409 (2011) 2693-2699. doi:10.1016/j.scitotenv.2011.04.018.

[26] M. Lee, A.A. Keller, P.C. Chiang, W. Den, H. Wang, C.H. Hou, J. Wu, X. Wang, J. Yan, Waterenergy nexus for urban water systems: A comparative review on energy intensity and environmental impacts in relation to global water risks, Appl. Energy. 205 (2017) 589-601. doi:10.1016/j.apenergy.2017.08.002.

[27] K.H. Chen, H.C. Wang, J.L. Han, W.Z. Liu, H.Y. Cheng, B. Liang, A.J. Wang, The application of footprints for assessing the sustainability of wastewater treatment plants: A review, J. Clean. Prod. 277 (2020) 124053. doi:10.1016/j.jclepro.2020.124053.

[28] H. Zhuang, J. Guan, S.Y. Leu, Y. Wang, H. Wang, Carbon footprint analysis of chemical enhanced primary treatment and sludge incineration for sewage treatment in Hong Kong, J. Clean. Prod. 272 (2020) 122630. doi:10.1016/j.jclepro.2020.122630.

[29] O.P. Koutsou, G. Gatidou, A.S. Stasinakis, Domestic wastewater management in Greece: Greenhouse gas emissions estimation at country scale, J. Clean. Prod. 188 (2018) 851-859. doi:10.1016/j.jclepro.2018.04.039.

[30] P. Singh, A. Kansal, C. Carliell-Marquet, Energy and carbon footprints of sewage treatment methods, J. Environ. Manage. 165 (2016) 22-30. doi:10.1016/j.jenvman.2015.09.017.

[31] IPCC, Climate change 2014: synthesis report, Geneva, Switzerland, 2014.

[32] X. Yan, L. Li, J. Liu, Characteristics of greenhouse gas emission in three full-scale wastewater treatment processes, J. Environ. Sci. (China). 26 (2014) 256-263. doi:10.1016/S10010742(13)60429-5.

[33] A.G. Schneider, A. Townsend-Small, D. Rosso, Impact of direct greenhouse gas emissions on the carbon footprint of water reclamation processes employing nitrification-denitrification, Sci. Total Environ. 505 (2015) 1166-1173. doi:10.1016/j.scitotenv.2014.10.060.

[34] M. Asadi, K. McPhedran, Estimation of greenhouse gas and odour emissions from a cold region municipal biological nutrient removal wastewater treatment plant, J. Environ. Manage. 281 (2021) 111864. doi:10.1016/j.jenvman.2020.111864.

[35] A. Ribera-Guardia, L. Bosch, L. Corominas, M. Pijuan, Nitrous oxide and methane emissions from a plug-flow full-scale bioreactor and assessment of its carbon footprint, J. Clean. Prod. 212 (2019) 162-172. doi:10.1016/j.jclepro.2018.11.286.

[36] E.S. Heidrich, T.P. Curtis, J. Dolfing, Determination of the internal chemical energy of wastewater, Environ. Sci. Technol. 45 (2011) 827-832. doi:10.1021/es103058w.

[37] I. Shizas, D.M. Bagley, Experimental Determination of Energy Content of Unknown Organics in Municipal Wastewater Streams, J. Energy Eng. 130 (2004) 45-53. doi:10.1061/(ASCE)07339402(2004)130:2(45).

[38] J.M. Garrido, M. Fdz-Polanco, F. Fdz-Polanco, Working with energy and mass balances: A conceptual framework to understand the limits of municipal wastewater treatment, Water Sci. Technol. 67 (2013) 2294-2301. doi:10.2166/wst.2013.124. 
[39] X. Hao, J. Li, M.C.M. van Loosdrecht, H. Jiang, R. Liu, Energy recovery from wastewater: Heat over organics, Water Res. 161 (2019) 74-77. doi:10.1016/j.watres.2019.05.106.

[40] O. Nowak, P. Enderle, P. Varbanov, Ways to optimize the energy balance of municipal wastewater systems: Lessons learned from Austrian applications, J. Clean. Prod. 88 (2015) 125-131. doi:10.1016/j.jclepro.2014.08.068.

[41] Y. Shen, J.L. Linville, M. Urgun-Demirtas, M.M. Mintz, S.W. Snyder, An overview of biogas production and utilization at full-scale wastewater treatment plants (WWTPS) in the United States: Challenges and opportunities towards energy-neutral WWTPs, Renew. Sustain. Energy Rev. 50 (2015) 346-362. doi:10.1016/j.rser.2015.04.129.

[42] W.W. Mo, Q. Zhang, Can municipal wastewater treatment systems be carbon neutral?, J. Environ. Manage. 112 (2012) 360-367. doi:10.1016/j.jenvman.2012.08.014.

[43] G. Silvestre, B. Fernández, a. Bonmatí, Significance of anaerobic digestion as a source of clean energy in wastewater treatment plants, Energy Convers. Manag. 101 (2015) 255-262. doi:10.1016/j.enconman.2015.05.033.

[44] J. Wagner, D.G. Weissbrodt, V. Manguin, R.H. Ribeiro da Costa, E. Morgenroth, N. Derlon, Effect of particulate organic substrate on aerobic granulation and operating conditions of sequencing batch reactors, Water Res. 85 (2015) 158-166. doi:10.1016/j.watres.2015.08.030.

[45] N. Derlon, J. Wagner, R.H.R. da Costa, E. Morgenroth, Formation of aerobic granules for the treatment of real and low-strength municipal wastewater using a sequencing batch reactor operated at constant volume, Water Res. $105 \quad$ (2016) 341-350. doi:10.1016/j.watres.2016.09.007.

[46] E. Dulekgurgen, S. Doğruel, Ö. Karahan, D. Orhon, Size distribution of wastewater COD fractions as an index for biodegradability, Water Res. 40 (2006) 273-282. doi:10.1016/j.watres.2005.10.032.

[47] A. Alvarado, S. West, G. Abbt-Braun, H. Horn, Hydrolysis of particulate organic matter from municipal wastewater under aerobic treatment, Chemosphere. 263 (2021) 128329. doi:10.1016/j.chemosphere.2020.128329.

[48] P. Zhou, M.N.A. Meshref, B.R. Dhar, Optimization of thermal hydrolysis process for enhancing anaerobic digestion in a wastewater treatment plant with existing primary sludge fermentation, Bioresour. Technol. 321 (2021) 124498. doi:10.1016/j.biortech.2020.124498.

[49] R. Dimock, E. Morgenroth, The influence of particle size on microbial hydrolysis of protein particles in activated sludge, Water Res. 40 (2006) 2064-2074. doi:10.1016/j.watres.2006.03.011.

[50] G. Lettinga, S. Rebac, G. Zeeman, Challenge of psychrophilic anaerobic wastewater treatment, Trends Biotechnol. 19 (2001) 363-370. doi:10.1016/S0167-7799(01)01701-2.

[51] R.M. McKeown, D. Hughes, G. Collins, T. Mahony, V. O'Flaherty, Low-temperature anaerobic digestion for wastewater treatment, Curr. Opin. Biotechnol. 23 (2012) 444-451. doi:10.1016/j.copbio.2011.11.025.

[52] H. Guven, R.K. Dereli, H. Ozgun, M.E. Ersahin, I. Ozturk, Towards sustainable and energy efficient municipal wastewater treatment by up-concentration of organics, Prog. Energy Combust. Sci. 70 (2019) 145-168. doi:10.1016/j.pecs.2018.10.002. 
[53] I. Sancho, S. Lopez-Palau, N. Arespacochaga, J.L. Cortina, New concepts on carbon redirection in wastewater treatment plants: A review, Sci. Total Environ. 647 (2019) 1373-1384. doi:10.1016/j.scitotenv.2018.08.070.

[54] J. Wan, J. Gu, Q. Zhao, Y. Liu, COD capture: A feasible option towards energy self-sufficient domestic wastewater treatment, Sci. Rep. 6 (2016) 1-9. doi:10.1038/srep25054.

[55] J. Jimenez, M. Miller, C. Bott, S. Murthy, H. De Clippeleir, B. Wett, High-rate activated sludge system for carbon management - Evaluation of crucial process mechanisms and design parameters, Water Res. 87 (2015) 476-482. doi:10.1016/j.watres.2015.07.032.

[56] A. Bezirgiannidis, P. Chatzopoulos, A. Tsakali, S. Ntougias, P. Melidis, Renewable energy recovery from sewage sludge derived from chemically enhanced precipitation, Renew. Energy. 162 (2020) 1811-1818. doi:10.1016/j.renene.2020.10.005.

[57] R.W. Baker, Membrane Technology and Applications, 2nd ed., Wiley, California, 2012.

[58] S. Arabi, M.L. Pellegrin, J. Aguinaldo, M.E. Sadler, R. McCandless, S. Sadreddini, J. Wong, M.S. Burbano, S. Koduri, K. Abella, J. Moskal, S. Alimoradi, Y. Azimi, A. Dow, L. Tootchi, K. Kinser, V. Kaushik, V. Saldanha, Membrane processes, Water Environ. Res. 92 (2020) 1447-1498. doi:10.1002/wer.1385.

[59] S. Alzahrani, A.W. Mohammad, Challenges and trends in membrane technology implementation for produced water treatment: A review, J. Water Process Eng. 4 (2014) 107 133. doi:10.1016/j.jwpe.2014.09.007.

[60] S. Hube, M. Eskafi, K.F. Hrafnkelsdóttir, B. Bjarnadóttir, M.Á. Bjarnadóttir, S. Axelsdóttir, B. Wu, Direct membrane filtration for wastewater treatment and resource recovery: A review, Sci. Total Environ. 710 (2020) 136375. doi:10.1016/j.scitotenv.2019.136375.

[61] B. Wu, Membrane-based technology in greywater reclamation: A review, Sci. Total Environ. 656 (2019) 184-200. doi:10.1016/j.scitotenv.2018.11.347.

[62] M.G. Buonomenna, J. Bae, Membrane processes and renewable energies, Renew. Sustain. Energy Rev. 43 (2015) 1343-1398. doi:10.1016/j.rser.2014.11.091.

[63] S. Judd, The MBR Book: Principles and Applications of Membrane Bioreactors in Water and Wastewater Treatment, Elsevier, 2006.

[64] W. Guo, H.-H. Ngo, J. Li, A mini-review on membrane fouling., Bioresour. Technol. 122 (2012) 27-34. doi:10.1016/j.biortech.2012.04.089.

[65] M. Zhang, E. Lee, E. Vonghia, Y. Hong, B. Liao, Introduction to aerobic membrane bioreactors: Current status and recent developments, Elsevier B.V., 2020. doi:10.1016/B978-0-12819809-4.00001-2.

[66] W. Sohn, W. Guo, H.H. Ngo, L. Deng, D. Cheng, X. Zhang, A review on membrane fouling control in anaerobic membrane bioreactors by adding performance enhancers, J. Water Process Eng. 40 (2021) 101867. doi:10.1016/j.jwpe.2020.101867.

[67] S. Vinardell, S. Astals, M. Peces, M.A. Cardete, I. Fernández, J. Mata-Alvarez, J. Dosta, Advances in anaerobic membrane bioreactor technology for municipal wastewater treatment: A 2020 updated review, Renew. Sustain. Energy Rev. 130 (2020). doi:10.1016/j.rser.2020.109936.

[68] J. Gouveia, F. Plaza, G. Garralon, F. Fdz-Polanco, M. Peña, Long-term operation of a pilot scale anaerobic membrane bioreactor (AnMBR) for the treatment of municipal wastewater under 
psychrophilic conditions, Bioresour. Technol. $185 \quad$ (2015) 225-233. doi:10.1016/j.biortech.2015.03.002.

[69] A. Hafuka, T. Takahashi, K. Kimura, Anaerobic digestibility of up-concentrated organic matter obtained from direct membrane filtration of municipal wastewater, Biochem. Eng. J. 161 (2020) 107692. doi:10.1016/j.bej.2020.107692.

[70] S.K. Lateef, B.Z. Soh, K. Kimura, Direct membrane filtration of municipal wastewater with chemically enhanced backwash for recovery of organic matter, Bioresour. Technol. 150 (2013) 149-155. doi:10.1016/j.biortech.2013.09.111. 



\section{AJISS AND SCOPE}

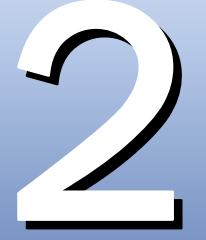

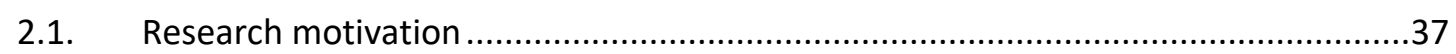

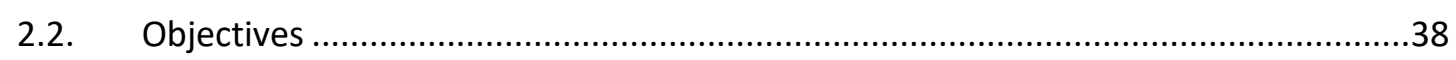

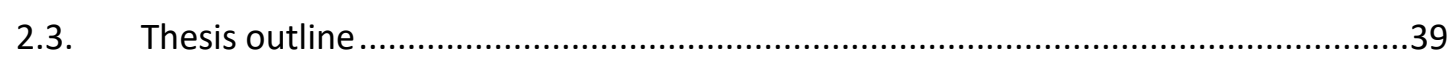





\subsection{Research motivation}

The municipal wastewater treatment is a fundamental subject towards the equilibrium between human development and sustainable growth. The global pressure against pollution, waste generation and energy consumption has also emerged as a concern for the conventional wastewater treatment plants. Although effective in delivering treated water that fits with local legislations, most of the conventional wastewater treatment processes are characterized for having a high energy consumption, generating high amount of excess sludge, releasing of greenhouse gases and they are not prepared for facing most stringent legislations.

Considering this, it is crucial for the future of the sustainable wastewater treatment plants the study and development of novel technologies capable of not only overcoming the contamination and the energy consumption issues but also providing a source of clean energy throughout the recovery of carbon content embedded in the municipal wastewater streams. The municipal wastewaters are recognized for containing a high amount of organic matter, and the membrane-based processes have been widely considered for occupying the role of carbon capturer processes, but some operational constraints still delay its widespread use.

In this context, the so-called Direct Membrane Filtration (DMF) rises as a simple, robust and resilient technology for capturing the organic matter from municipal wastewater streams with high potential of being efficient and finally shift the wastewater treatment plant paradigm towards a true resource recovery facility. Nevertheless, much research is still required to understand the process behavior at long-term operation with real municipal wastewater, and to overcome the inherently process constraints and limitations, such as membrane fouling, low to medium filtration fluxes, membrane cleaning necessities, and overall energy balance. 
This thesis addresses the most important limitations of working with DMF in continuous short-term and long-term operations with real municipal wastewaters at pilot-scale and indicates practical solutions for a full-scale operation. In this way, the efficiency of the process regarding the quality of the produced permeate, the concentration of the recovered matter, the potential methane production, the strategies against fouling formation, the membrane cleaning protocols, and the general feasibility of the process were studied with experimental research.

\subsection{Objectives}

This work focuses on the improvement of the direct membrane filtration technology when applied for the municipal wastewater up-concentration, therefore prompting the energy recovering by anaerobic digestion. In order to achieve this major goal, several experiments were performed with a pilot plant operating in continuous mode with different real municipal wastewaters. Specific objectives are following listed.

- Feasibility assessment of ultrafiltration membrane module for the separation and concentration process of particulate matter from municipal wastewater.

- Evaluation of up-concentrated organic matter in terms of solid and organic matter concentration

- Assessment of the organic matter biodegradability.

- Improvement of operating parameters for optimize the water production and reduce the energy consumption.

- Analysis of the effect of applying common protocols for the membrane cleaning and fouling control.

- Energy evaluation of the direct membrane filtration process considering the power consumption and the carbon recovery. 


\subsection{Thesis outline}

The objectives before determined were pursued with several experiments and literature review culminating in scientific publications that are the subject of the next chapters of this thesis. Therefore, the objectives have being addressed according to the following:

Chapter 4: T.A. Nascimento, F. Fdz-Polanco, M. Peña, Membrane-Based Technologies for the Up-Concentration of Municipal Wastewater: A Review of Pretreatment Intensification, Sep. Purif. Rev. 49 (2020) 1-19. doi:10.1080/15422119.2018.1481089.

This literature review is important for understanding the scientific place of the membrane-based processes and the promising future for the DMF of municipal wastewater. This article draws the major advantages and current limitations to be solved before the full-scale application of this technology, besides indicating the main practices for the continuous operation. Therefore, this work has been taken as a guide for the experimental designs.

Chapter 5: T.A. Nascimento, F.R. Mejía, F. Fdz-Polanco, M. Peña, Improvement of municipal wastewater pretreatment by direct membrane filtration, Environ. Technol. 38 (2017) 2562-2572. doi:10.1080/09593330.2016.1271017.

This article reported the preliminary experiments for the up concentration of domestic wastewater. The long-term performance of the DMF was evaluated with the monitoring of the transmembrane pressures, maximum concentration of recovered solids and the biodegradability, the impact over the quality of produced water and the general membrane module behavior.

Chapter 6: T.A. Nascimento, M.P. Miranda, Continuous municipal wastewater upconcentration by direct membrane filtration, considering the effect of intermittent gas 
scouring and threshold flux determination, J. Water Process Eng. 39 (2021). doi:10.1016/j.jwpe.2020.101733.

In this work, the limits of the filtration process were determined with the assessment of the main operating parameters combined. With the combination of different permeate fluxes, gas scouring velocities, and wastewater concentrations, some optimal operating conditions were defined for both short and long-term processes.

Chapter 7: T.A. Nascimento, M.P. Miranda, Control strategies for the long-term operation of direct membrane filtration of municipal wastewater, J. Environ. Chem. Eng. (2021). doi:10.1016/j.jece.2021.105335.

In this paper, the most common practices reported in the literature were combined in order to provide efficient and cheaper strategies that allow the DMF of operating at long-term without jeopardizing the quality of the recovered solid and with minimal energy consumption. Chemical addition, intermittent gas scouring, and periodical purge combined with permeate backwash were studied.

Chapter 8: M. Peña, T. do Nascimento, J. Gouveia, J. Escudero, A. Gómez, A. Letona, J. Arrieta, F. Fdz-Polanco, Anaerobic submerged membrane bioreactor (AnSMBR) treating municipal wastewater at ambient temperature: Operation and potential use for agricultural irrigation, Bioresour. Technol. 282 (2019) 285-293. doi:10.1016/j.biortech.2019.03.019.

- This author collaborates with this research with the installation, operation and maintenance of the AnSMBR pilot plant at the WWTP of Jumilla, in Jumilla (Spain), besides contributing with the article revision - 
This paper results from a long-term pilot-scale anaerobic submerged membrane bioreactor (AnMBR) operating at ambient temperature and outlines the use of the ultrafiltration membranes (precisely the same type for the DMF experiments) as an option for treating municipal wastewater. Whereas the DMF is focused the physical separation of carbon from wastewater for a posterior anaerobic mesophilic treatment, the AnSMBR combines both processes in a single bioreactor. However, by operating at low temperature, some important constraints like low methane production e poor quality of produced water still needs to be solved. Nevertheless, this technology is also a feasible option for moderate to high temperature countries. 

MVAJEERIALS AND MVIEJHOD

$3)$ 



\subsection{Experimental setups and methodology}

The main experiments were carried out on pilot-scale with real municipal wastewater after minor preliminary treatments such as coarse and fine screens and

grit chamber. Particular differences in some preliminary treatments appear as a consequence of the pilot plant location: at the Department of Chemical Engineering and Environmental Technologies in the Science Faculty (University of Valladolid), at the full-scale WWTP of Renedo de Esgueva, in Renedo de Esgueva city (Spain) or, at WWTP of Santovenia de Pisuerga, in Santovenia de Pisuerga city (Spain). The general setup and pilot plant configurations, including the membrane module, the membrane tank (MT) and the digital data acquisition system, are precisely the same along the performed experiments, except when stated otherwise. Detailed plant setup and methodology are described from the following section.

A submerged anaerobic membrane bioreactor operating at ambient temperature is also outlined with a different configuration and operating procedure. The membrane bioreactor and its overall setup differ from the other experimental configurations, nonetheless, the characteristics of the two membrane modules used and the data acquisition system are the same of the other experiments.

Following is a detailed description regarding the DMF experiments.

\subsubsection{Setup for the wastewater collection}

The experiments described in Chapter 5 were performed with the pilot plant located at the Department of Chemical Engineering and Environmental Technology. Fig. 3.1 shows a schematic representation of the wastewater collection and treatment in the pilot plant in this location. This figure is an adaptation of the Figure 1 in Chapter 5. For that reason, the equipment codes between parenthesis are the same, although minor differences in the setup details are represented. 


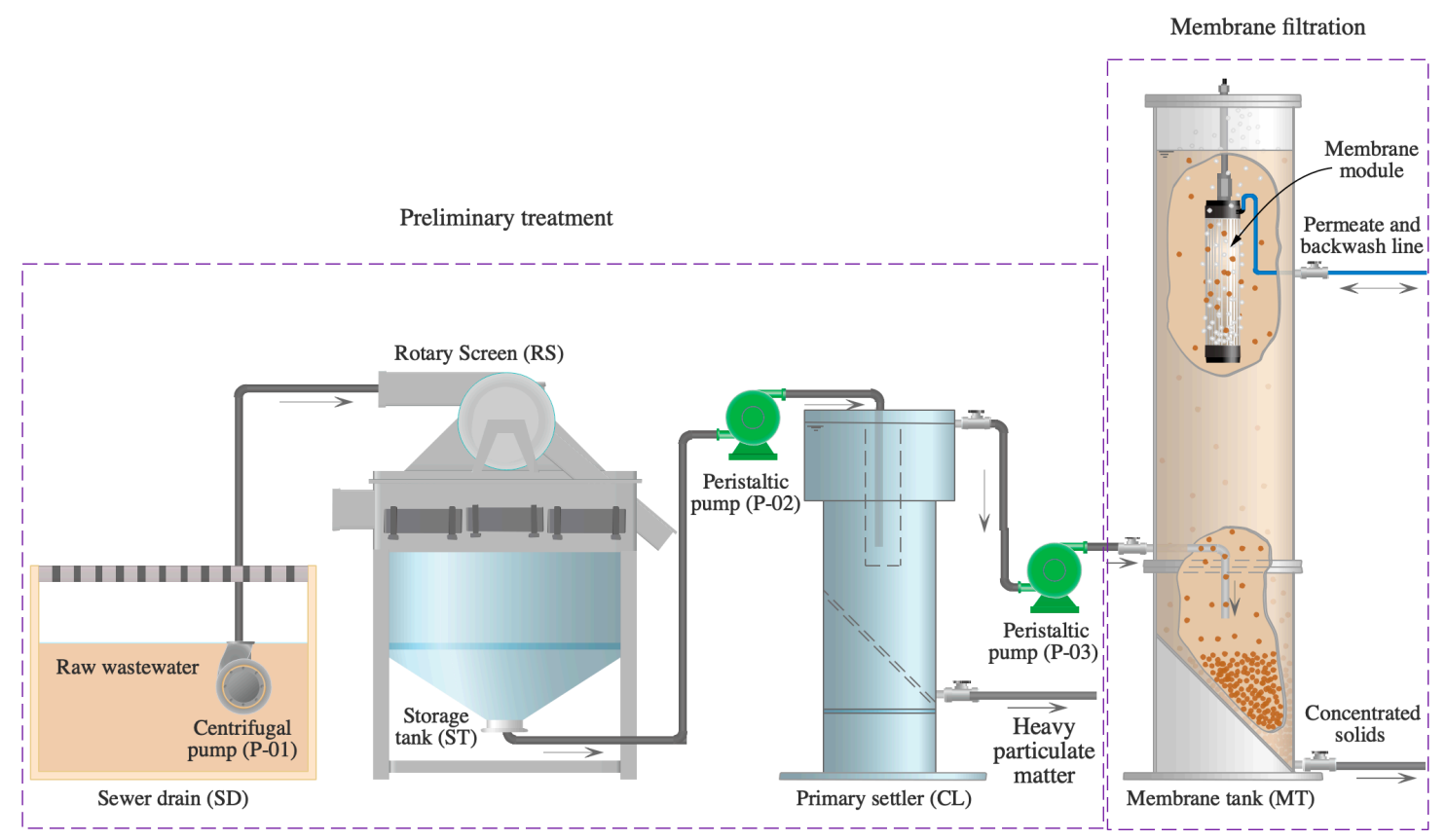

Figure 3.1 - Schematic representation of the pilot plant setup for the experiments with domestic wastewater described in Chapter 5 (Science Faculty).

The municipal wastewater was collected from the sanitary system of a residential area near to the department. After drained into a sewer drain (SD), a positive displacing centrifugal pump (P-01) delivered the raw wastewater into a storage tank (ST) after passing through a coupled stainless steel rotary screen (RS) (TORO ${ }^{\circledR}$ Equipment, TR - 4/25, 0.5 mm mesh, Valladolid, ES) (Fig. 3.2).
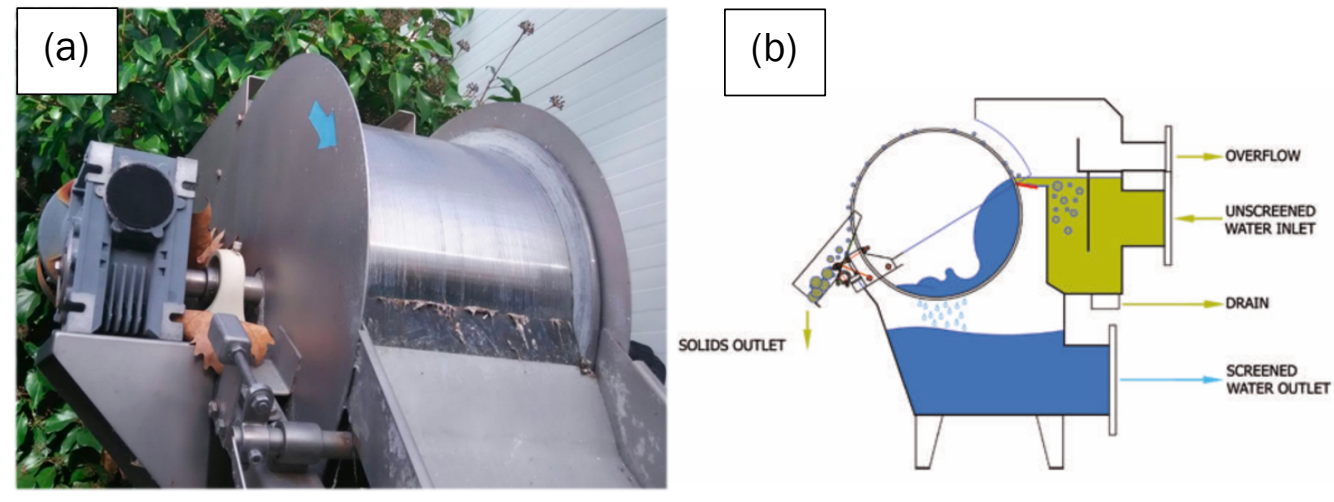

Figure 3.2 - Real picture (a) and schematic representation (b) of the rotary screen used in the preliminary treatment for the experiments described in Chapter 5 (Science Faculty). 
The storage wastewater was periodically replaced by fresh wastewater each $6 \mathrm{~h}$ in order to avoid biological oxidation and solids accumulation. Thereafter, a peristaltic pump (P-02) (Watson Marlon, 520S, Madrid, ES) continuously feeds a 58 $\mathrm{L}$ primary settler, or clarifier $(\mathrm{CL})$, ending the preliminary treatment. In Fig. 3.3 are provided details of the primary settler.
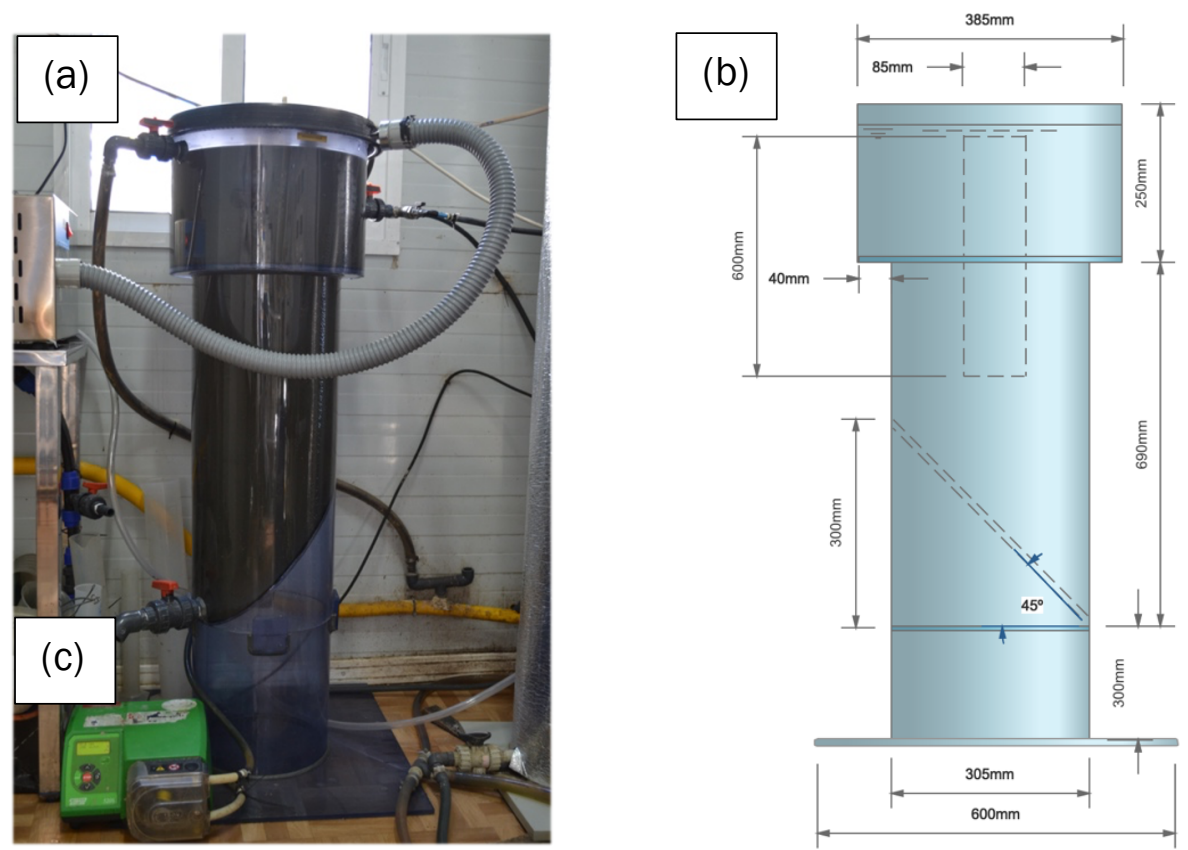

Figure 3.3 - Real picture (a) and dimensioning (b) of the primary settler, and peristaltic pump (P-02) (c) used in the preliminary treatment for the experiments described in Chapter 5 (Science Faculty).

The pilot experiments described in Chapter 6 were performed at the WWTP of Renedo de Esgueva, in Renedo de Esgueva city (3.800 inhabitants, approx.). The full scale WWTP has as preliminary treatment a ditch for the removal of large materials, fine screens and an aerated grit chamber. From the grit chamber, an installed submerged centrifugal pump continuously conveys the wastewater to a polyethylene storage tank from which a peristaltic pump is used for feeding the membrane tank, according to the scheme of Fig. 3.4. An overflow pipe ensures that the wastewater in to the storage tank has been continuously renewed by fresh wastewater. Since the wastewater is proceeding from a grit chamber, the pilot primary settler was not used. 


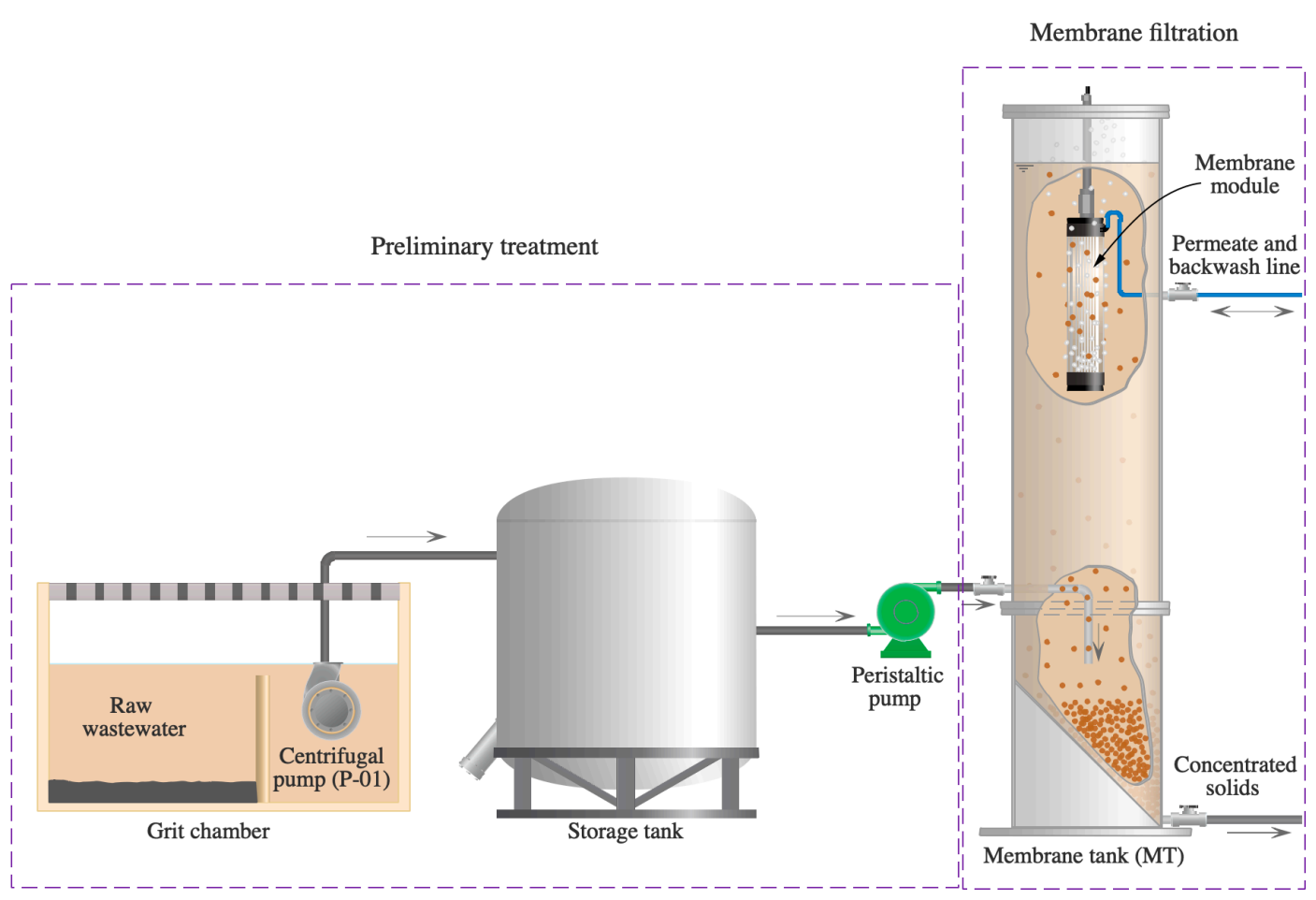

Figure 3.4 - Schematic representation of the pilot plant setup for the experiments with municipal wastewater described in Chapter 6 (Renedo de Esgueva WWTP).

The experiments described in Chapter 7 were performed at the WWTP of Santovenia de Pisuerga, in Santovenia de Pisuerga city (4.600 inhabitants). This WWTP has the specific characteristic of having a mixed wastewater, i.e., the wastewater presents both domestic and industrial compounds. The pilot plant setup, on another hand, is basically the same as the presented in Figure 3.4 with an intermediary ditch replacing the storage tank, from which the wastewater is collected and conveyed to the membrane tank.

\subsubsection{Membrane tank characteristics and setup}

The membrane tank (MT) and the accessory equipment were the same, along with all experiments. The MT is a polypropylene cylinder of $1.76 \mathrm{~m}$ in height and 0.34 $\mathrm{m}$ in diameter, with an effective volume of $126 \mathrm{~L}$. The membrane module is placed 
centralized in the upper section and it is hanged from the top connected to the tank cap.

In some experiments it is said the membrane module is surrounded by a protection, an "airlift". This airlift is a cylinder made of PVC with $0.15 \mathrm{~m}$ diameter and $0.69 \mathrm{~m}$ in height coupled to the membrane module, which is used to direct the gas scouring to the membrane fibers instead of expanding the gas scouring along the MT diameter. Therefore, with this device, it is possible to apply higher gas velocities, besides avoiding agitation of the settled solids. When not mentioned, the airlift is not used.

The MT section immediately on the membrane surrounds, defined as upper section, or filtration section, is the one with lower concentrations of particulate matter, since the heavier particles are settled into the lower section by gravity. The lower section, therefore, comprised the most concentrated content within the membrane tank. The feeding wastewater reaches the center of this section and is directed downwards through a "deflector tube", which is used to hinder the larger particles from rising out into the filtration section. Moreover, this section is built-in with a baffle plate in order to concentrate the solids into a specific direction, in which a valve is connected in order to perform the solids purge.

Fig. 3.5 shows the MT dimensioning (a), the external aspect of the MT (b), the connection detail of the membrane module with airlift (c) and without airlift (d), and the internal details of the lower section with the built-in deflector and baffle plate (e). 


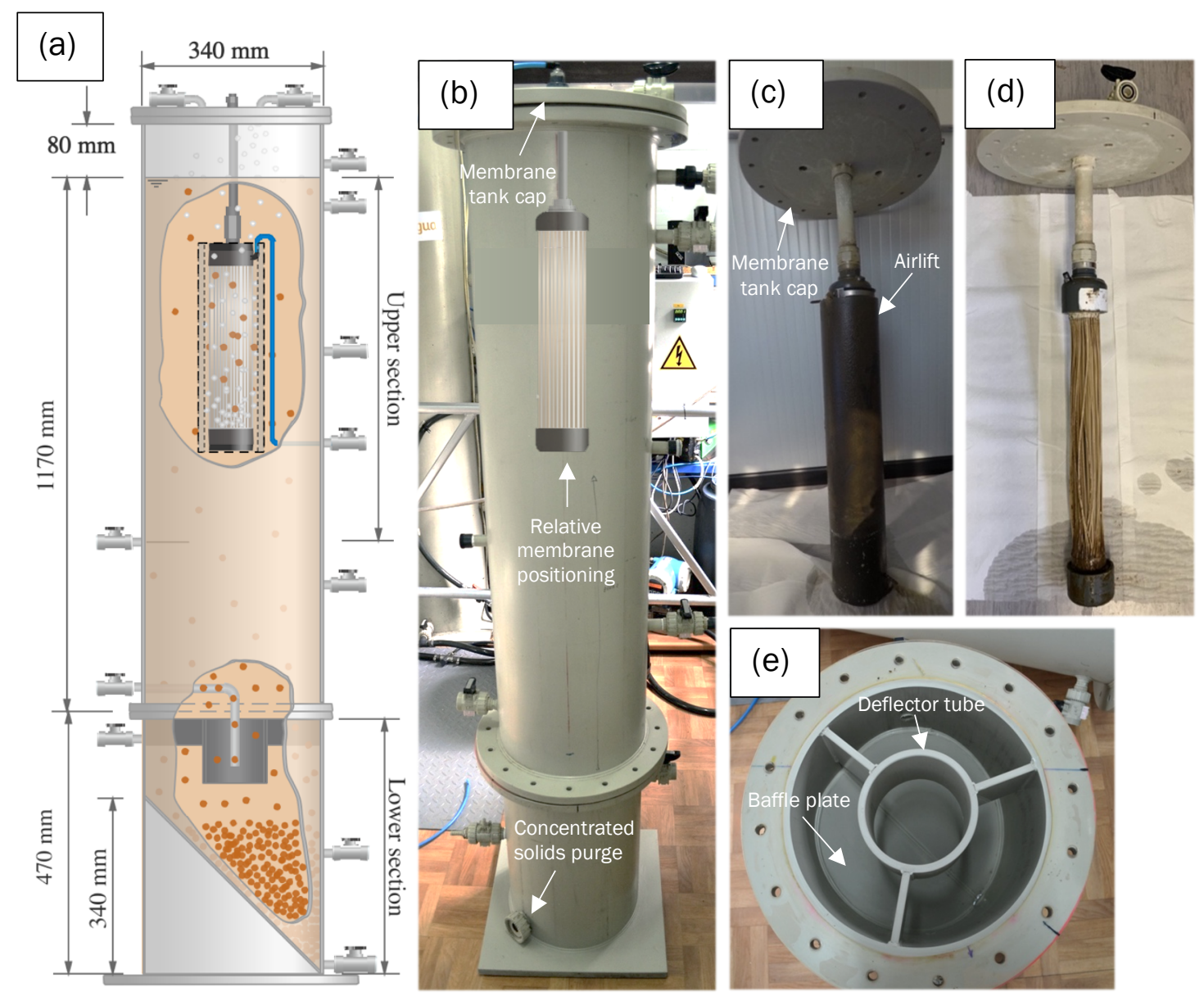

Figure 3.5 - Membrane tank dimensioning (a), external aspect of the membrane tank (a), membrane module with airlift (b), membrane module without airlift (c) and detail of the lower section of the membrane tank (d).

Several accessory equipment and valves are part of the general membrane tank setup. These instruments were used to measure temperature and pressures, to control the gas scouring velocity and frequency, and to set the feed and permeate flows and frequency. Fig. 3.6 shows the MT with the electrical boards and computer (a), and a schematic representation of the main instruments (b) connected to the MT and the sampling points (valves) used to sampling along the experiments (sp1, sp2, sp3 sp4 and sp5). 

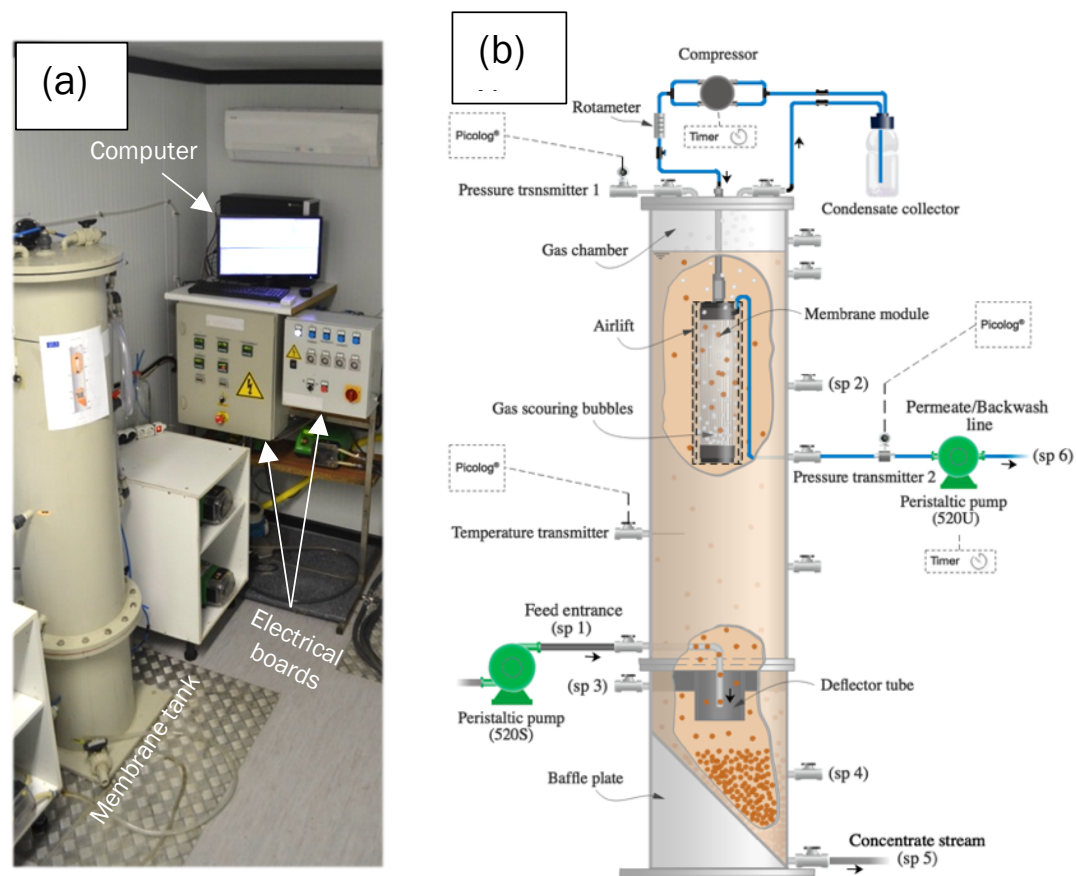

Figure 3.6 - Membrane tank, electrical board and computer (a) and scheme of main instruments setup (b).

In Table 3.1 are shown the main instruments, the description of its use and reference information.

Table 3.1 - Main pilot plant instrument specifications

\begin{tabular}{|c|c|c|}
\hline Instrument & Application & Reference \\
\hline Peristaltic pump (feed) & $\begin{array}{l}\text { Feeding wastewater into the } \\
\text { membrane tank }\end{array}$ & $\begin{array}{l}\text { Watson Marlon, 520S, } \\
\text { Madrid, ES }\end{array}$ \\
\hline $\begin{array}{l}\text { Peristaltic pump } \\
\text { (filtration/backwash) }\end{array}$ & Filtration and backwash fluxes & $\begin{array}{l}\text { Watson Marlon, 520U, } \\
\text { Madrid, ES }\end{array}$ \\
\hline Compressor & $\begin{array}{l}\text { Gas scouring over the membrane } \\
\text { module }\end{array}$ & SECOH, SV50, Barcelona, ES \\
\hline Pressure transmitter 1 & $\begin{array}{l}\text { Measures the pressure in the gas } \\
\text { chamber }\end{array}$ & $\begin{array}{l}\text { Endress + Hauser, PMC 131, - } \\
1 \text { to } 1 \text { bar, Valladolid, ES }\end{array}$ \\
\hline Pressure transmitter 2 & $\begin{array}{l}\text { Measures the filtration and } \\
\text { backwash pressures }\end{array}$ & $\begin{array}{l}\text { Endress + Hauser, PMC 131, - } \\
1 \text { to } 1 \text { bar, Valladolid, ES }\end{array}$ \\
\hline Temperature transmitter & Measure temperature inside MT & $\begin{array}{l}\text { Desin Instruments, PT-100, } 0 \\
-100^{\circ} \mathrm{C}, \text { Valladolid, ES }\end{array}$ \\
\hline $\begin{array}{l}\text { Picolog }{ }^{\circledR} \text { data acquisition } \\
\text { software }\end{array}$ & $\begin{array}{l}\text { System of data register card and } \\
\text { software used for pressure and } \\
\text { temperature data recording }\end{array}$ & $\begin{array}{l}\text { Picolog Technology Ltd } \\
\text { (2007-2010) }\end{array}$ \\
\hline Rotameter & Control flow of gas scouring & $\begin{array}{l}\text { Cole Parmer, } 0 \text { to } 50 \mathrm{~L} / \mathrm{min} \text {, } \\
\text { Valladolid, ES }\end{array}$ \\
\hline
\end{tabular}




\subsubsection{Membrane module characteristics and setup}

The ultrafiltration membrane module used throughout the experiments is made of polyvinylidene fluoride (PVDF) and it is a hollow-fiber type, outside-in configured. Table 3.2 resumes its main characteristics.

Table 3.2 - Characteristics of the membrane module used throughout the experiments

\begin{tabular}{lcc}
\hline \multicolumn{1}{c}{ Parameter } & Value & Unit \\
\hline Model & Zenon ZeeWeed ${ }^{\circledR}$ ZW-10 & \\
Nominal filtration area & 0.93 & $\mathrm{~m}^{2}$ \\
Module weight (dry) & 1.93 & $\mathrm{Kg}$ \\
Module weight (wet) & 2.1 & $\mathrm{Kg}$ \\
Nominal pore size & 0.04 & $\mathrm{\mu m}$ \\
Maximum transmembrane pressure & $62^{(1)}$ & $\mathrm{KPa}$ \\
Typical permeate production & $0.5-0.75^{(2)}$ & $\mathrm{L} / \mathrm{min}$ \\
Typical TMP of operation & $10-5 \mathrm{O}^{(1)}$ & $\mathrm{Kpa}$ \\
Maximum working temperature & 40 & ${ }^{\circ} \mathrm{C}$ \\
Operating pH range & $5-9$ & \\
Maximum cleaning temperature & 40 & ${ }^{\circ} \mathrm{C}$ \\
pH cleaning range & $2-10.5$ & \\
Maximum exposure to OCl- & 1000 & $\mathrm{ppm}$ \\
Maximum pressure backwash & 55 & $\mathrm{KPa}$ \\
\hline (1) At 40 $40^{\circ} \mathrm{C} \cdot(2)$ depending on the application
\end{tabular}

Fig. 3.7 shows the membrane module (a) and the fibers detail (b).

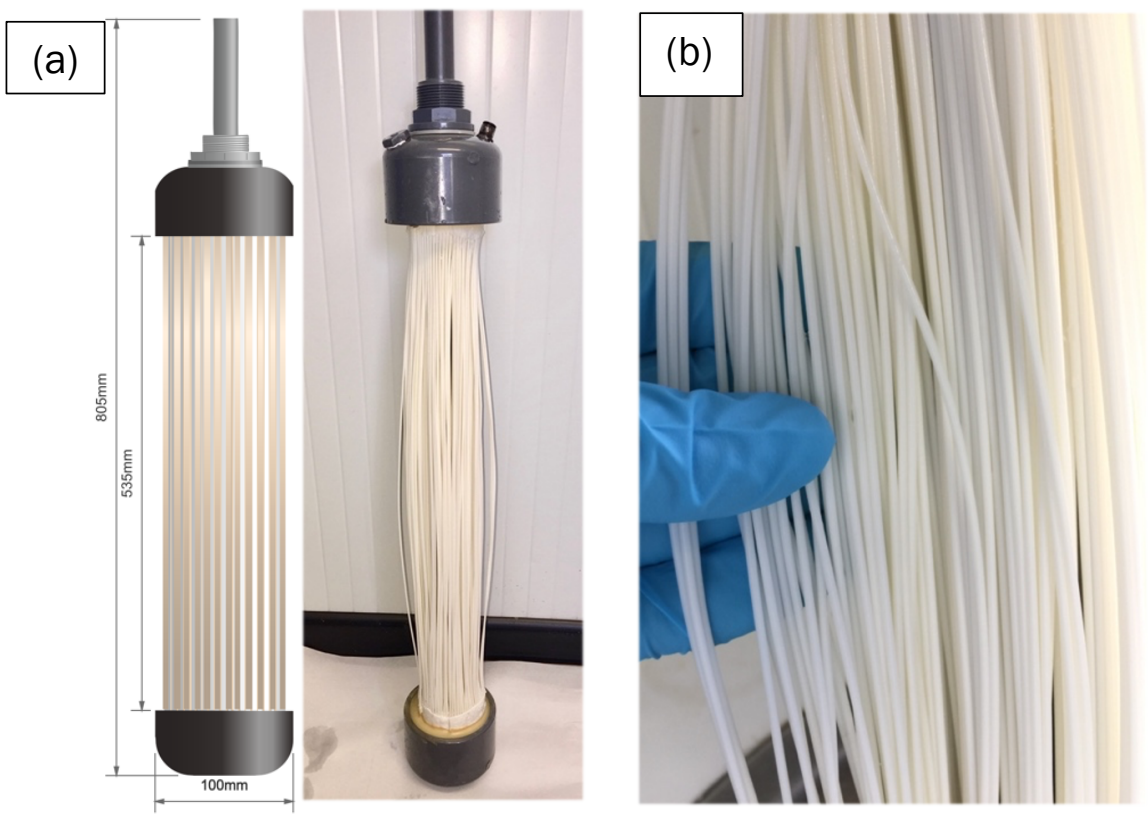

Figure 3.7 - Membrane module dimensioning (a) and fibers detail (b) 


\subsubsection{Data acquisition system}

The measure data was collected and stored by the Picolog ${ }^{\circledR}$ data acquisition card and processed by the Picolog ${ }^{\circledR}$ software. The program was configured to collect all measured data (temperature and pressures) each $3 \mathrm{~s}$. Therefore, it was possible to follow with precision the filtration behavior. Nevertheless, for simplifying, the graphics of filtration and backwash only present a ser of data with negligible loss of the real behavior.

\subsubsection{Chemical assays and sampling}

Total COD, soluble COD, total solids (TS), volatile solids (VS), total suspended solids (TSS) and volatile suspended solids (VSS) were determined according to the Standard Methods for the Examination of Water and Wastewater [1]. Samples for the long-term operation process were collected from the sampling points labelled sp1, sp2, sp3, sp4, sp5 and sp6 (see Fig. 3.6) in order to monitor the concentration processes.

\subsubsection{Biochemical methane potential assays (BMPs)}

BMP assays at mesophilic temperature $\left(35^{\circ} \mathrm{C}\right)$ were performed along the experiments in order to measure the biodegradability degree of recovered solids (substrate). The tests were always performed in triplicate + blank in serum bottles of $160 \mathrm{~mL}$. The anaerobic sludge used as inoculum always proceeds from an anaerobic digester either from a full-scale or a pilot-scale WWTP. In each experiment the inoculum was previously incubated in order to minimize its residual biodegradable organic matter content. The serum bottles were filled with $80 \mathrm{~mL}$ of inoculum plus substrate and the remaining $80 \mathrm{~mL}$ of headspace was reserved for accumulating the produced biogas. The same inoculum ratio $(\mathrm{S} / \mathrm{X})$ of $0.4 \mathrm{gVSS}_{\text {subs }} / \mathrm{gVSS}_{\text {inoc }}$ was applied 
for all BMPs assays. Serum bottles without substrate (a blank test) were also included. After sealed with rubber septa and aluminum crimp caps, the serum bottles were gassed with Helium and carried to the orbital shaker. The biogas production was estimated by measuring the biogas pressure, using a pressure meter (ifm electronics, PI 1696, -124 to 2500 mbar, Valladolid, ES), and the composition, using a gas chromatograph (Varian, CP-3800, Palo Alto, CA, USA) along the experiment. Samples of biogas were extracted with a syringe (Hamilton, 1710 SL SYR, 100 $\mu$ L, Valladolid, ES). With these data, and using the general gas equation, it is possible to measure the partial pressures of the gases and the methane production. The monitoring of the biogas composition is done daily until the stabilization of the biogas production, which is verified by the constant pressure and constant biogas composition over the last days of the anaerobic digestion.

\subsubsection{Out of place setup for the membrane cleanings}

The membrane module was used throughout the experiments, therefore the membrane cleaning was necessary for recovering the permeability and, sometimes, when the membrane cleaning was being subjected of study.

The physical cleaning comprises removing the membrane module from the membrane tank and jetting tap water on the membrane fibers with the auxiliary of a soft sponge. It consists of a simple procedure, but efficient for recover the reversible fouling. The chemical cleanings, on another hand, were performed with the membrane module immersed in the dissolution within a PVC cylindrical tube of $0.15 \mathrm{~m}$ of diameter and $1.8 \mathrm{~m}$ height. During the cleaning, the membrane module was connected to the filtration/backwash pump so the membrane fibers could be both externally and internally cleaned. Gas agitation was also provided to the dissolution to enhance the chemical diffusivity. Fig. 3.8 shows the membrane module immersed 
in the cylindrical tube (a) used for the cleanings and the membrane module aspect before cleanings (b), after physical cleaning (c) and after chemical cleanings (d).

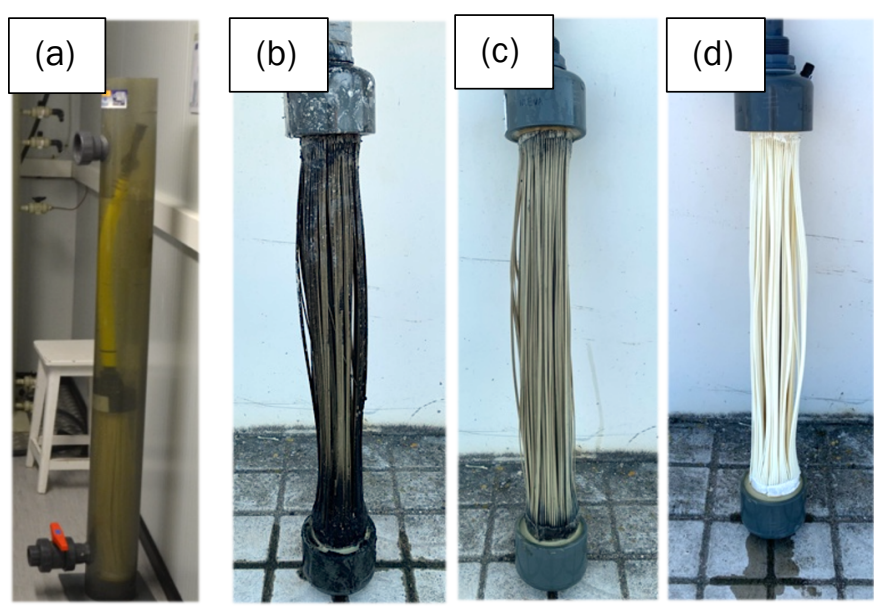

Figure 3.8 - Cylindrical tube for membrane cleanings (a), membrane module before cleanings (b), after physical cleaning (c), and after chemical cleaning (d)

\subsection{References}

[1] APHA, Standard Methods for the Examination of Water and Wastewater, 22nd ed., American Public Health Association, Washington D.C., 2012. 



\section{ذJens.grss

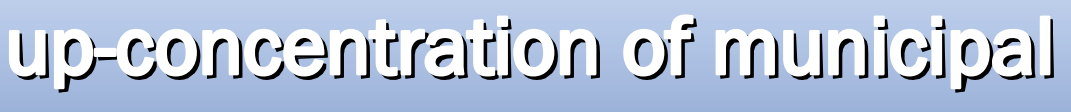 \\ westewarters a review of pretreatinent intensification}

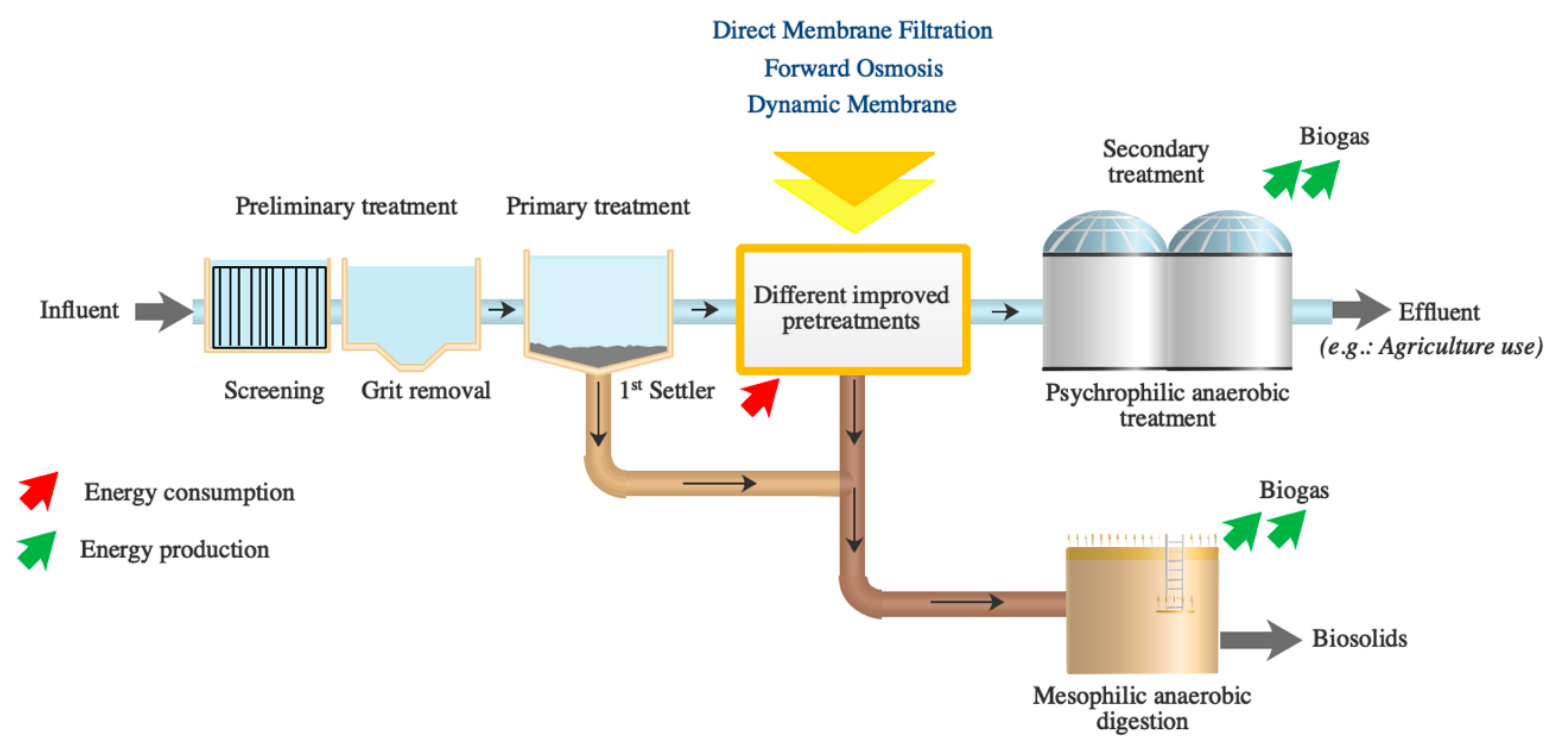





\title{
Membrane-based technologies for the up-concentration of municipal wastewater: a review of pretreatment intensification
}

\author{
Thiago A. Nascimentoa, Fernando Fdz-Polancoª, Mar Peñaa* \\ a Department of Chemical Engineering and Environmental Technology. University of Valladolid. Spain. \\ *Corresponding author. Tel.: +34 983423166. E-mail address: pena@iq.uva.es
}

\begin{abstract}
Municipal wastewater has a high content of recoverable energy, distributed within particulate and soluble organic matter. It is estimated that the anaerobic treatment of that content and the recovery of biogas energy could supply at least enough power to render a wastewater treatment plant electrically self-sufficient. Therefore, an intensification of wastewater pretreatment could separate and concentrate the organic matter in order to improve the anaerobic stabilization of both the solids and the water streams. In light of this, membrane-based processes have been considered as novel technologies in order to recover carbon from municipal wastewater. In this work, direct membrane filtration, forward osmosis and dynamic membrane have been reviewed as possible membrane-based technologies for the up-concentration of wastewater. A literature overview has been performed in order to elucidate the main operational parameters and to compare the advantages and downsides of every pretreatment reported up until now.
\end{abstract}

Keywords: Wastewater up-concentration, carbon recovery, direct membrane filtration, psychrophilic anaerobic treatment, wastewater intensive pretreatment 


\section{Introduction}

Sustainable water resource technologies have become an important issue in global development and environmentally friendly practices. Intensive wastewater treatments can overcome problems associated with high energy consumption, land requirements and the environmental impact caused by typical wastewater treatment plants (WWTPs). The activated sludge (AS) process is widely used worldwide, but the specific power consumption (SPC) corresponding to the air supply for the oxidation of the organic matter, around $0.3 \mathrm{kWh} / \mathrm{m}^{3}[1,2]$, represents at least half of the energy required by the entire WWTP. Moreover, the oxidation of the organic matter contributes to the release of carbon dioxide into the atmosphere, thus further compromising the carbon neutrality goal over the lifetime of the WWTP. Despite the large amount of electrical energy needed for the wastewater treatment, the sewage itself actually contains the source of the renewable energy and could provide its own self-sufficiency [3]. Since the combustion value for raw sewage is $3.86-4.08 \mathrm{kWh} / \mathrm{kg}$ of the chemical oxygen demand (COD) oxidized [2,4], an anaerobic treatment could take advantage of the organic matter through biogas production. Thus, the key to the self-sustainability of WWTPs seems to lie in the improved reclamation of energetic content from biodegradable fractions of wastewater, by means of anaerobic treatments and further biogas application in order to cogenerate heat and power. However, the small organic load of municipal wastewater, at $260-900 \mathrm{mg} / \mathrm{L}$ of the COD [5], reveals a low practical potential for the anaerobic treatment of the main stream of water at a low temperature, unless other technologies could be applied in order to separate and concentrate the recoverable COD fraction from the raw sewage.

Raw municipal wastewater has organic matter divided into four main fractions: nonbiodegradable soluble COD (SCOD), nonbiodegradable particulate COD, biodegradable SCOD and biodegradable particulate COD [5]. The total particulate 
content corresponds to approximately $65 \%$ of the total COD (tCOD) [6], with $22 \%$ ascribed to the biodegradable particulate fraction [7]. This latter fraction is slowly hydrolyzed in biological processes. Besides the partial oxidation, both particulate and soluble biodegradable fractions are partially used for the growth of aerobic microorganisms, and afterward, they are partially converted into methane by means of the anaerobic digestion of waste activated sludge (WAS) from the AS process.

The losses caused by oxidation in the aerobic reactors may represent about $45 \%$ of the total biodegradable COD [1] which, in contrast, might be used to produce biogas. In addition, the methane produced during the anaerobic digestion of WAS only satisfies $50 \%$ of the total energy required by the WWTP, since the COD is in low concentration and the cogeneration equipment is not usually highly efficient [8].

Thus, the separation and concentration of organic matter from the upstream section of the WWTP could represent an important strategy for energy recovery, since there would be no losses by aerobic oxidation. Furthermore, solid concentration has been reported as a main factor in the achievement of surplus energy production by anaerobic digestion, since high concentrations reduce the wasting of energy due to heating water [9-11] and depending on the system used to separate and concentrate organic matter from municipal wastewater, a clarified water stream could be produced which could then be anaerobically treated at a low temperature, thus further increasing biogas recovery. In direct membrane filtration (DMF), for example, the stream of particulate COD could be stabilized by mesophilic anaerobic digestion, while the sCOD, present in the main permeate stream, could be converted into biogas under anaerobic psychrophilic conditions [12-15]. Figure 1 contrasts the conventional municipal WWTP (a) and the proposed system (b) with an improved pretreatment that favors solid concentration and recovery. The conventional aerobic treatment is commonly followed by a negative net energy balance, while the new 
proposed treatment could allow an increase resulting in a positive net energy balance.

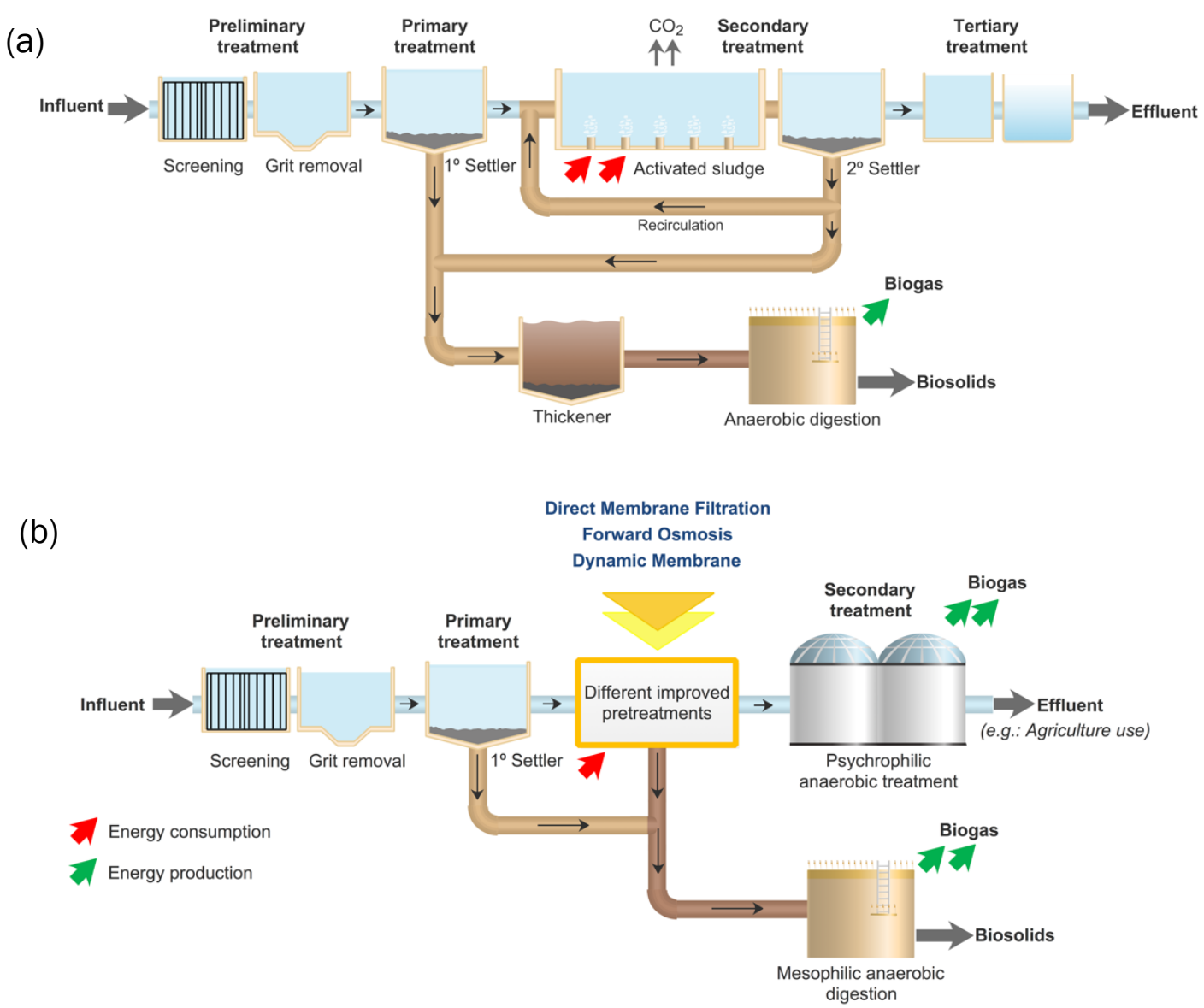

Figure 1 - (a) Conventional municipal wastewater treatment plant and (b) proposed wastewater treatment with different processes to improve solid up- concentration.

With regard to this, some technologies are currently being investigated, with the aim of harvesting the main content of particulate COD from municipal wastewater as close as possible to the feed of the WWTP. As depicted in Figure 1b, DMF, forward osmosis (FO) and dynamic membrane (DM) are all possible technologies for the upconcentration of wastewater, allowing anaerobic treatments of both solids and permeate streams and generating a surplus in biogas production when compared with AS. 
Membrane filtration is one of the most promising technologies for achieving sewage up-concentration. The modular design, sophisticated automation, pore size flexibility, huge resistance to work with a large variety of effluents and reliable permeate quality are the major tags for the acceptance of membrane technology as a newer approach to wastewater treatment $[16,17]$. Aerobic membrane bioreactors (MBRs) are well established and widespread [18]. However, membrane-based technologies for municipal wastewater up-concentration, like DMF, may represent concepts that favor less energy consumption, due to their capability to separate the complete content of particulate COD and to produce a permeate stream that is completely free of suspended solids. Since energy consumption is less associated with air supply or heating, the DMF could have a more positive net energy balance. Nevertheless, membrane fouling is a real concern in membrane-based processes, since taking action to mitigate the fouling requires additional spending. Notwithstanding, membrane fouling has been controlled by techniques such as chemically enhanced backwash (CEB) [19], coagulation [20], air backflushing [21] or the mechanical agitation and vibration of the membrane module [22].

Coagulation/flocculation is commonly used in solid- liquid separation processes. Usually, it is integrated with the membrane-based process in order to enhance the sedimentation of colloidal particles inside the membrane tank in a DMF process. The combined coagulation/adsorption and membrane filtration could even allow high COD concentrations with a low membrane resistance, as reported by Gong et al. [23], and could produce cleaner effluents with high permeate fluxes, as reported by Abdessemed and Nezzal [24]. Coagulation/flocculation is not only a feasible operation for improving the solid concentration obtained from wastewater, but it also has a low SPC of between 0.003 and $0.01 \mathrm{kWh} / \mathrm{m}^{3}$ [25]. 
Other bolder technologies for sewage up-concentration have been studied, and good results have been achieved with relatively low SPC. This is the case described by Ma et al. [26], who developed an upflow DM filtration process for the recovery of organic matter from low-strength municipal wastewater. On the other hand, Zhang et al. [27] used a FO process, with synthetic seawater as a draw solution (DS) in order to concentrate low-strength wastewater. Wang et al. [28] also reported an organic matter concentration achieved through FO that was high enough to present economic benefits through anaerobic digestion, according to these authors.

Although some researchers have found remarkable results regarding the upconcentration of the organic matter from municipal wastewater, there is still a lack of knowledge concerning the main operational characteristics that influence the processes, such as operating time, resulting COD concentrations, membrane fouling, cleaning requirements and addition of coagulant/adsorbent to the influent among others. In order to support the assessment of membrane-based technologies for the recovery of carbon from municipal wastewater, a literature review has taken place, focusing on the existing intensive pretreatments of wastewater that aim to separate and up-concentrate particulate COD. A comparison of advantages and disadvantages was also performed, taking into consideration DMF, FO and DM filtration, based on the bibliography studied.

\section{Direct membrane filtration}

Physical-chemical processes have been used for a long time as a potential alternative to a more sustainable WWTP. Since raw municipal wastewater contains a large fraction of suspended and colloidal particles, the application of appropriate technology could reduce the load of organic pollutants to posttreatments [29], resulting in easier and cheaper wastewater treatment. Pressure-driven membrane- 
based processes have gained notoriety in the last decades for meeting the required small footprint, high reliability and high quality of product generated at relative low cost [30]. In the field of wastewater treatment, the membranes are mainly applied in reverse osmosis (RO, pore diameter between 0.1 and $1 \mathrm{~nm})$, nanofiltration (1-10 $\mathrm{nm}$ ), ultrafiltration (UF, 10-100 nm) and microfiltration (MF, $100 \mathrm{~nm}-1 \mu \mathrm{m})$ which can be used in a large variety of schemes in order to achieve a specific water quality. The technique of DMF has been recognized as a promising technology in municipal wastewater treatment due to its potential suitability to the so-called ZeroWasteWater treatment concept, a process designed to separate and concentrate organic matter from municipal wastewater and, therefore, to minimize COD losses via aerobic oxidation and thus improve carbon recovery by anaerobic digestion at a later stage [31]. The DMF could operate in submerged or sidestream configurations, depending on whether the membrane module is placed inside or outside the tank that receives the wastewater. In this work, the literature consulted concerning the DMF process reported that most systems were operating with the submerged configuration and, only in a few cases, in sidestream configuration.

\subsection{Advantages of DMF for Municipal Wastewater Up-concentration}

\section{Physical process}

The DMF is a purely physical process, which supposes a greater operational facility than biological treatments. Constraints inherent in biological processes such as sensibility to flow variations, raw wastewater characteristics, toxic compounds, temperature conditions and solid retention time are not major concerns for the DMF technology. 


\section{Modularity}

Membrane modules can be easily changed, resized or replaced, and despite their high filtration surface, they occupy a small area, allowing for high production with relatively simple equipment. Hence, the DMF unit can be installed in many different WWTPs, either alone or combined with preinstalled primary treatments like sedimentation and coagulation/flocculation processes.

\section{Permeate quality}

Membranes of MF and UF are those most frequently used in DMF investigations regarding municipal wastewater up-concentration. The latter type of membrane produces a permeate completely free of suspended solids. Most of the colloidal particles are also removed, as well as a large variety of harmful pathogens. Then, the permeate can be treated by a further physical or biological treatment in order to recover SCOD and remaining inorganic content like nitrogen, phosphorus and potassium salts.

\section{High solid concentration}

The totality of suspended solids is separated and concentrated inside the membrane tank. As previously mentioned, the particulate matter from raw municipal wastewater corresponds to about $65 \%$ of the tCOD. This high loaded particulate stream could be conveyed to mesophilic anaerobic digestion, generating energy for plant operation. Another plant configuration could also increase the biogas production if the permeate stream was anaerobically treated under low temperature. In this case, both the solid and water streams would supply organic carbon for methane production. 


\subsection{Disadvantages of DMF for Municipal Wastewater Up-concentration}

\section{Membrane fouling}

This is the major obstacle to the DMF implementation on a large scale because it implies influx decline, periodic physical and chemical cleanings and the decreasing service life of the membrane. The fouling of membranes depends on the physical and chemical factors regarding the treated wastewater characteristics, membrane properties and the system operation mode, including the concentration of solids inside the membrane tank and the permeate flux.

\section{Low permeate fluxes}

The high content of suspended solids has an impact on the rate of the membrane fouling. Hence, essential antifouling techniques are needed in order to maintain and restore the membrane permeability and, consequently, a working permeate flux. However, sometimes these techniques are not cheap, and their implementation increases the expenditure of the operation process.

\section{Replacement cost}

In the last decades, the costs of both membranes and processes have decreased as a result of improvements in process design, operation and maintenance schedules and greater membrane lifetime than were previously estimated. Since the membrane replacement is related to the ratio of the membrane cost $(\$)$ to the net flux $(\mathrm{J})$ times the membrane life $(\mathrm{t})[\$ /(\mathrm{J} t)]$, the membrane purchase cost is still a key concern, although it has rapidly decreased from 400-500 $\$ / m^{2}$ to $15-25 \$ / m^{2}$ within the last three decades [32]. 


\subsection{Operating Conditions and Carbon Recovery in DMF}

Despite the downsides to the DMF process, efforts have been made to guarantee a stable operation, reliable treatment process and a positive economic balance by ensuring a proper recovery of COD from municipal wastewater. A comparative study of publications over the last years revealed some common operational characteristics, both in membrane configurations and in values of operational parameters. The main operating conditions for DMF reported in literature, related to the membrane type, wastewater pretreatments and applied antifouling techniques, are presented in Table 1.

The values of COD and solid concentrations in wastewater influent and permeate streams, as well as the maximum COD and solid concentrations reached inside the membrane tank at the end of the filtration process, are shown in Table 2.

Regarding the membrane module, the polyvinylidene fluoride (PVDF) type is the most common in hollow-fiber out-in configuration and also prevailed in submerged con- figuration [19-23,33,34]. Other materials were also tried, such as polyethersulfone [35], polyethylene [36,37] and polypropylene [38], all of them in submerged configuration. By contrast, Nieuwenhuijzen et al. [39] (PVDF membrane), Ravazzini et al. [40] (PVDF membrane), Bendick et al. [41] (alumina ceramic membrane), Abdessemed and Nezzal [24] (zirconia ceramic membrane) and Ramon et al. [42] (poly- amide membrane) operated the DMF in sidestream mode. Most of the membrane pore sizes used ranged between 0.03 and $0.4 \mu \mathrm{m}$, characterizing the processes as UF or MF. In order to decrease the propensity to fouling formation, it makes sense to use a screening and/or settler prior to mem- brane filtration. 
Table 1 - Characteristics of direct membrane filtration (DMF) process for municipal wastewater treatment

\begin{tabular}{|c|c|c|c|c|c|c|c|c|}
\hline $\begin{array}{c}\text { Material/ } \\
\text { configuration }\end{array}$ & $\begin{array}{l}\text { Pore } \\
\text { size }\end{array}$ & $\begin{array}{c}\text { Total } \\
\text { filtration area }\end{array}$ & $\begin{array}{c}\text { Tank } \\
\text { volume }\end{array}$ & $\begin{array}{c}\text { Wastewater } \\
\text { pre-treatment }\end{array}$ & Filtration flux & $\begin{array}{l}\text { Operating time } \\
\text { before membrane } \\
\text { chemical cleaning }\end{array}$ & $\begin{array}{l}\text { Antifouling techniques } \\
\text { (in-line) }\end{array}$ & Ref. \\
\hline $\begin{array}{l}\text { (a)PVDF/hollow-fibre, } \\
\text { out-in, submerged }\end{array}$ & $\begin{array}{l}0,04 \mu \mathrm{m} \\
\text { (ultra) }\end{array}$ & $0.93 \mathrm{~m}^{2}$ & $136 \mathrm{~L}$ & $\begin{array}{l}\text { Screening }(1 \mathrm{~mm}) \text {, } \\
\text { settler }\end{array}$ & $10 \mathrm{~L} /\left(\mathrm{m}^{2} . \mathrm{h}\right)$ & 54 days & $\begin{array}{l}\text { Continuous recirculated air scouring } \\
\text { and permeate backflush (during } 15 \mathrm{~s} \\
\text { every } 7.6 \mathrm{~min} \text { ) }\end{array}$ & [33] \\
\hline $\begin{array}{l}\text { PVDF/hollow-fibre, } \\
\text { out-in, submerged }\end{array}$ & $\begin{array}{l}0.1 \mu \mathrm{m} \\
\text { (micro) }\end{array}$ & $1 \mathrm{~m}^{2}$ & $28 \mathrm{~L}$ & $\begin{array}{l}\text { Screening, } \\
\text { equalization }\end{array}$ & $13.3 \mathrm{~L} /\left(\mathrm{m}^{2} . \mathrm{h}\right)$ & $295 \mathrm{~h}$ & $\begin{array}{c}\text { Continuous coagulation ((b)PAC } 30 \\
\mathrm{mg} / \mathrm{L}) \text { and intermittent aeration ( } 3 \\
\text { min every } 15 \mathrm{~min})\end{array}$ & [20] \\
\hline $\begin{array}{l}\text { Polyethersulfone/Flat- } \\
\text { sheet, out-in, } \\
\text { submerged }\end{array}$ & $\begin{array}{l}0.07 \mu \mathrm{m} \\
\text { (ultra) }\end{array}$ & $0.04 \mathrm{~m}^{2}$ & $3.75 \mathrm{~L}$ & Settler and septic tank & $20 \mathrm{~L} /\left(\mathrm{m}^{2} . h\right)$ & $72 \mathrm{~h}$ & $\begin{array}{c}\text { Continuous air scouring } \\
\text { and intermittent filtration } \\
\text { (8 min filt./2 min relaxation) }\end{array}$ & [35] \\
\hline $\begin{array}{l}\text { PVDF/hollow-fibre, } \\
\text { out-in, submerged }\end{array}$ & $\begin{array}{l}0.1 \mu \mathrm{m} \\
\text { (micro) }\end{array}$ & $24 \mathrm{~m}^{2}$ & $300 \mathrm{~L}$ & Raw wastewater & $5 \mathrm{~L} /\left(\mathrm{m}^{2} . \mathrm{h}\right)$ & $144 \mathrm{~h}$ & $\begin{array}{l}\text { Coagulant (PAC), adsorbent } \\
\text { (activated carbon) and intermittent } \\
\text { filt. (10 min filt./2 min relax.) }\end{array}$ & [23] \\
\hline $\begin{array}{l}\text { PVDF/hollow-fibre, } \\
\text { out-in, submerged }\end{array}$ & $\begin{array}{l}0.3 \mu \mathrm{m} \\
\text { (micro) }\end{array}$ & $0.33 \mathrm{~m}^{2}$ & $3.5 \mathrm{~L}$ & $\begin{array}{l}\text { Screening, } \\
\text { equalization }\end{array}$ & $20 \mathrm{~L} /\left(\mathrm{m}^{2} . \mathrm{h}\right)$ & $93 \mathrm{~h}$ & $\begin{array}{c}\text { Coagulant (PAC- } 30 \mathrm{mg} / \mathrm{L} \text { ) and Air- } \\
\text { backflush (at } 50 \mathrm{kPa})\end{array}$ & {$[21]$} \\
\hline $\begin{array}{l}\text { PVDF/hollow-fibre, } \\
\text { out-in, submerged }\end{array}$ & $\begin{array}{l}0.1 \mu \mathrm{m} \\
\text { (micro) }\end{array}$ & $\begin{array}{l}0.1 \mathrm{~m}^{2} / \\
0.03 \mathrm{~m}^{2}\end{array}$ & $0.75 \mathrm{~L}$ & Settler & $\begin{array}{l}20.8 \mathrm{~L} /\left(\mathrm{m}^{2} . h\right) / \\
16.7 \mathrm{~L} /\left(\mathrm{m}^{2} . h\right)\end{array}$ & $\begin{array}{l}200 \mathrm{~h} \text { (until conc. } \\
\text { factors } 21 \text { and } 50 \text { ) }\end{array}$ & $\begin{array}{c}\text { Aeration (4 L/min) and } \\
\text { (c)CEB (during } 30 \text { s every 12h) }\end{array}$ & [19] \\
\hline $\begin{array}{l}\text { PVDF/hollow-fibre, } \\
\text { out-in, submerged }\end{array}$ & $\begin{array}{l}0,03 \mu \mathrm{m} \\
\text { (ultra) }\end{array}$ & $0,093 m^{2}$ & $6 \mathrm{~L}$ & $\begin{array}{l}\text { Settler/ Coag. (PAC)- } \\
\text { Floc-Sed. }\end{array}$ & 2.5-39 L/(m².h) & Few hours & $\begin{array}{l}\text { Permeate backflush (20-85s, at } 23 \\
\qquad /\left(m^{2} . h\right)\end{array}$ & {$[34]$} \\
\hline $\begin{array}{l}\text { Chlorinated } \\
\text { Polyethylene/Flat } \\
\text { sheets, submerged }\end{array}$ & $\begin{array}{l}0.4 \mu \mathrm{m} \\
\text { (micro) }\end{array}$ & $0.016 \mathrm{~m}^{2}$ & $1.5 \mathrm{~L}$ & NI (Raw wastewater) & $12.8 \mathrm{~L} /\left(\mathrm{m}^{2} . \mathrm{h}\right)$ & $20 \mathrm{~h}$ & $\begin{array}{c}\text { Continuous Air scouring / Continuous } \\
\text { Vibration }(45 \mathrm{~Hz})\end{array}$ & [36] \\
\hline $\begin{array}{l}\text { Commercial/ } \\
\text { sandwich flat-sheet, } \\
\text { submerged }\end{array}$ & $\begin{array}{l}0.4 \mu \mathrm{m} \\
\text { (micro) }\end{array}$ & $4.5 \mathrm{~m}^{2}$ & $120 \mathrm{~L}$ & NI (Raw wastewater) & $6.9 \mathrm{~L} /\left(\mathrm{m}^{2} . \mathrm{h}\right)$ & $120 \min$ & $\begin{array}{l}\text { Intermittent filt. ( } 9 \text { min filt. } / 2 \text { min } \\
\text { relax.) and intermittent aeration ( } 2 \\
\text { min after } 9 \text { min filt.) }\end{array}$ & [43] \\
\hline
\end{tabular}


Table 1 (continued)

\begin{tabular}{|c|c|c|c|c|c|c|c|c|}
\hline $\begin{array}{c}\text { Material/ } \\
\text { configuration }\end{array}$ & $\begin{array}{l}\text { Pore } \\
\text { size }\end{array}$ & $\begin{array}{l}\text { Total } \\
\text { filtration area }\end{array}$ & $\begin{array}{c}\text { Tank } \\
\text { volume }\end{array}$ & $\begin{array}{l}\text { Wastewater } \\
\text { pre-treatment }\end{array}$ & Filtration flux & $\begin{array}{l}\text { Operating time } \\
\text { before membrane } \\
\text { chemical cleaning }\end{array}$ & Antifouling techniques (in-line) & Ref. \\
\hline $\begin{array}{l}\text { Polyethylene/hollow } \\
\text { fibre, out-in, } \\
\text { submerged }\end{array}$ & $\begin{array}{l}0.1 \mu \mathrm{m} \\
\text { (micro) }\end{array}$ & $20 \mathrm{~m}^{2}$ & - & Screening & $20 \mathrm{~L} /\left(\mathrm{m}^{2} . \mathrm{h}\right)$ & 120 days & $\begin{array}{l}\text { Continuous mechanical agitation, } \\
\text { intermittent filt. (10 min filt./ } 2 \text { min } \\
\text { relax.) and periodic purges }\end{array}$ & {$[37]$} \\
\hline $\begin{array}{l}\text { PVDF/hollow-fiber, in- } \\
\text { out, submerged }\end{array}$ & $0.1 \mu \mathrm{m}$ & - & $2.7 \mathrm{~L}$ & Settler & $\begin{array}{l}6.5 \mathrm{~L} /\left(\mathrm{m}^{2} . h\right) / \\
4.2 \mathrm{~L} /\left(\mathrm{m}^{2} . h\right)\end{array}$ & $30 d$ & $\begin{array}{l}\text { Mechanical agitation (300rp,), } \\
\text { Vibration in the module and } \\
\text { CEB with citric acid }\end{array}$ & {$[22]$} \\
\hline $\begin{array}{l}\text { PVDF- } \\
\text { polypropylene/flat- } \\
\text { sheet, out-in, } \\
\text { submerged }\end{array}$ & $\begin{array}{l}0,2 \mu \mathrm{m} \\
\text { (micro) }\end{array}$ & $1.025 \mathrm{~m}^{2}$ & $210 \mathrm{~L}$ & $\begin{array}{l}\text { Coag./Flocc./Microsieve } \\
(100 \mu \mathrm{m})\end{array}$ & $6.1 \mathrm{~L} /\left(\mathrm{m}^{2} . \mathrm{h}\right)$ & $159 \mathrm{~h}$ & $\begin{array}{l}\text { Continuous air scouring } \\
\text { and intermittent relaxation } \\
\text { (10 min filt./2 min relax.) }\end{array}$ & {$[38]$} \\
\hline $\begin{array}{l}\text { PVDF/tubular, in-out } \\
\text { sidestream }\end{array}$ & $\begin{array}{l}30 \mathrm{~nm} \\
\text { (nano) }\end{array}$ & $0.34 \mathrm{~m}^{2}$ & - & Raw wastewater & $70-110 \mathrm{~L} /\left(\mathrm{m}^{2} . \mathrm{h}\right)$ & Few hours & $\begin{array}{l}\text { Cross-flow velocities (1-2.5 m/s), } \\
\text { tap water backflush (during } 1 \mathrm{~min} \\
\text { every } 10 \mathrm{~min} \text { filt.) }\end{array}$ & {$[39]$} \\
\hline $\begin{array}{l}\text { PVDF/tubular, in-out, } \\
\text { sidestream }\end{array}$ & $\begin{array}{l}0.03 \mu \mathrm{m} \\
\text { (ultra) }\end{array}$ & $0.073 \mathrm{~m}^{2}$ & - & $\begin{array}{l}\text { Screening } \\
(0.56 \mathrm{~mm}) \\
\text { equalization }\end{array}$ & $160 \mathrm{~L} /\left(\mathrm{m}^{2} . \mathrm{h}\right)$ & $100 \min$ & $\begin{array}{l}\text { Cross-flow velocity }(2 \mathrm{~m} / \mathrm{s}) \text {, } \\
\text { demineralised water backflush } \\
\text { (during } 1 \text { min every } 10 \text { min filt.) }\end{array}$ & {$[40]$} \\
\hline $\begin{array}{l}\text { Ceramic/tubular, in- } \\
\text { out, sidestream }\end{array}$ & $\begin{array}{l}0.2 \mu \mathrm{m} \\
\text { (micro) }\end{array}$ & $0.36 \mathrm{~m}^{2}$ & - & Settler & $105 \mathrm{~L} /\left(\mathrm{m}^{2} . \mathrm{h}\right)$ & $72 \mathrm{~h}$ & $\begin{array}{l}\text { Cross-flow velocity }(1.8 \mathrm{~m} / \mathrm{s}) \text {, air } \\
\text { backflush (every } 60 \mathrm{~s})\end{array}$ & {$[41]$} \\
\hline $\begin{array}{l}\text { Polyamide/tubular, in- } \\
\text { out, sidestream }\end{array}$ & $\begin{array}{l}0.2 \mathrm{kDa} \\
\text { (nano) }\end{array}$ & 0.014 & $30 \mathrm{~L}$ & Raw greywater & $35 \mathrm{~L} /\left(\mathrm{m}^{2} . \mathrm{h}\right)$ & $150 \mathrm{~min}$ & $\begin{array}{l}\text { Cross-flow velocity } \\
\text { (value not indicated) }\end{array}$ & {$[42]$} \\
\hline $\begin{array}{l}\text { Ceramic/tubular, in- } \\
\text { out, sidestream }\end{array}$ & $\begin{array}{l}15 \mathrm{kDa} \\
\text { (ultra) }\end{array}$ & - & - & NI (Primary effluent) & $59.8 \mathrm{~L} /\left(\mathrm{m}^{2} . \mathrm{h}\right)$ & $180 \mathrm{~min}$ & $\begin{array}{l}\text { Coag. }\left(\mathrm{FeCl}_{3}-80 \mathrm{mg} / \mathrm{L}\right) / \\
\text { Adsorp. (act. carbon }-40 \mathrm{mg} / \mathrm{L}) \\
\text { Cross-flow velocity }(3 \mathrm{~m} / \mathrm{s})\end{array}$ & {$[24]$} \\
\hline
\end{tabular}

Note: the data reflect the better conditions in up-concentration and/or long-term experiments reported by the authors.

(a) Polyvinylidene Fluoride, (b) Polyaluminium chloride, (c) Chemically enhanced backwash 
Table 2 - Performance of municipal wastewater treatment by direct membrane filtration (DMF)

\begin{tabular}{|c|c|c|c|c|c|}
\hline \multicolumn{2}{|c|}{ Raw Wastewater } & \multirow{2}{*}{$\begin{array}{c}\text { Permeate } \\
\text { tCOD (mg/L) }\end{array}$} & \multicolumn{2}{|c|}{ Concentration achieved } & \multirow[t]{2}{*}{ Ref. } \\
\hline $\mathrm{tCOD} / \mathrm{sCOD}(\mathrm{mg} / \mathrm{L})$ & TSS (mg/L) & & tCOD (g/L) & TSS (g/L) & \\
\hline $876.9 / 532.5$ & 136.7 & 473.6 & 5.4 & $45.0^{(a)}$ & [33] \\
\hline $345.3 / 114.2$ & 240.3 & 39.7-35.5 & 16.0 & - & [20] \\
\hline $188 /-$ & - & $35-32$ & 1.022 & - & [35] \\
\hline $472 /-$ & 400 & $\simeq 75.5$ & $7.5-(\mathrm{b}) 0.112$ & - & [23] \\
\hline 339 / - & 200 & 84 & 15.0 & - & [21] \\
\hline $240 /-$ & $\simeq 129$ & $78-87$ & 5.0 & 27.130 & [19] \\
\hline$\simeq 368-488 /-$ & - & $18-72$ & - & - & [34] \\
\hline $497 / 44$ & - & 84 & 11.386 & - & [36] \\
\hline 413 / - & 207 & 64 & - & - & [43] \\
\hline $150 /-$ & 108 & 11 & - & 0.520 & [37] \\
\hline 265/ - & 165 & - & $\simeq 8$ & - & [22] \\
\hline 683.3/ - & - & 41 & - & - & [38] \\
\hline $680 /-$ & 130 & 210 & - & - & [39] \\
\hline 135/ - & 46 & 78 & - & - & [40] \\
\hline 216 / - & 141 & 76 & - & - & [41] \\
\hline 226 /- & 29.8 & 15 & - & - & [42] \\
\hline 165 / - & - & 7 & - & - & [24] \\
\hline
\end{tabular}

The data reflect the better conditions in up-concentration and/or long-term experiments reported by the authors.

(a) Corresponds to total solids.

(b) Corresponds to the concentration of settled tCOD inside the membrane tank 
Special attention has been paid to the permeate flux, or membrane flux rate $\left[\mathrm{L} /\left(\mathrm{m}^{2} . h\right)\right]$ which is a key variable of the DMF system as long as it establishes the amount of treated water per membrane surface. Moreover, the permeate flux in DMF is related to the transmembrane pressure (TMP), a driven force to wastewater filtration, and to the membrane fouling. Therefore, the permeate flux is an important parameter that affects the process economics. A wide range of permeate fluxes has been reported in many types of operation, depending mainly on the feeding water characteristics and the techniques applied to minimize fouling. The consulted bibliography reported values of permeate fluxes between 4 and $39 \mathrm{~L} /\left(\mathrm{m}^{2} . h\right)$ for membranes in submerged configuration and between 35 and $160 \mathrm{~L} /\left(\mathrm{m}^{2} . h\right)$ for sidestream configuration, as depicted in Table 1.

These values, however, are not comparable, even for those working on the same membrane configuration, due to the distinct operating conditions applied, such as the different methods used to control membrane fouling and the different solid concentrations. In some cases, the DMF process has been performed with continuous or intermittent aeration, with low to medium losses of organic matter, between $19 \%$ and $46 \%$ of COD content, due to biological oxidation or membrane capturing $[20,35,36]$. All these authors agree that it is still necessary to study a better arrangement for aeration or another antifouling strategy. The publications consulted reported different antifouling methods like coagulation/flocculation, continuous recirculated gas scouring, continuous or intermittent air scouring supply, vibrated membrane, mechanical agitation and backflush with permeate, chemicals, tap water or air. A schematic diagram of the DMF process with these strategies (1-6, in red boxes) is shown in Figure 2. These techniques are not necessarily applied together; indeed, the literature studied rarely reported three of these strategies at once when working on the same experiment. 


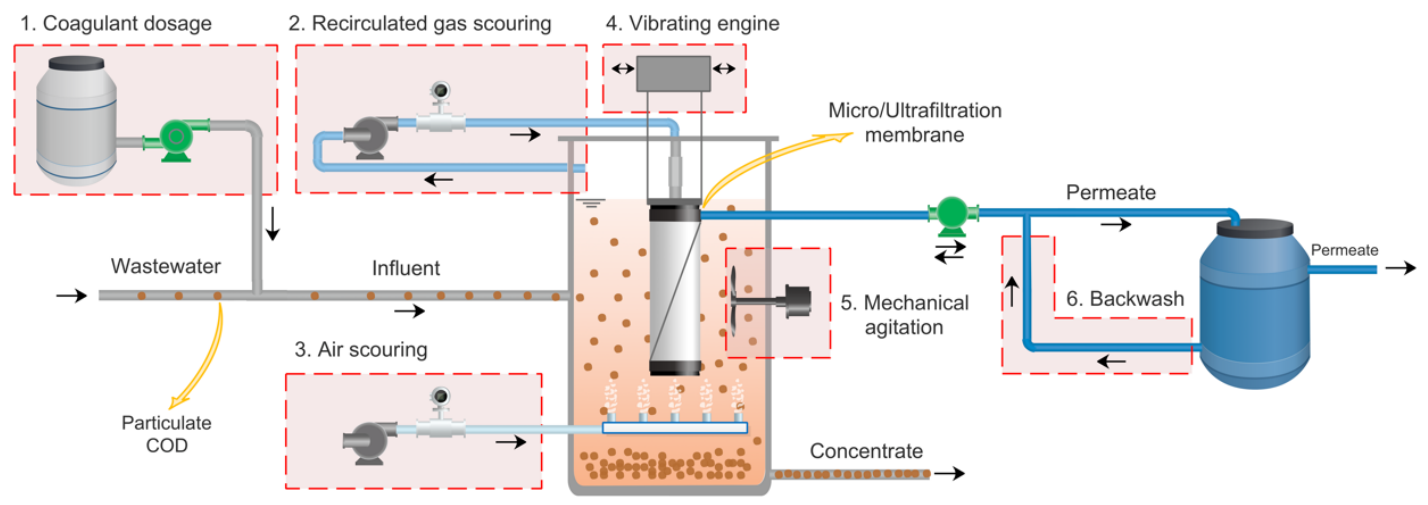

Figure 2 - Direct membrane filtration with different antifouling methods

In order to minimize the biodegradation of organics, Nascimento et al. [33], who worked with a $0.04 \mu \mathrm{m}$ pore size membrane, tried to control membrane fouling by applying continuous gas recirculation (about $55 \mathrm{~m}^{3}$ gas $/ \mathrm{m}^{3}$ permeate, initially using atmospheric air) without supplying additional external air to the system. Therefore, the COD oxidation could be minimized, the permeate fluxes could be increased from 2 up to $10 \mathrm{~L} /\left(\mathrm{m}^{2} . \mathrm{h}\right)$ and the TMP did not increase by more than $70 \mathrm{kPa}$. The total time length of the operation before the chemical cleaning of the membrane lasted 54 days, resulting in the production of a permeate that was completely free of suspended solids, and in a high concentration of organic matter in the retentate phase of approximately $45 \mathrm{~g} / \mathrm{L}$ of total solids. Jin et al. [20] found that the combination of coagulation [polyaluminum chloride, $30 \mathrm{mg} / \mathrm{L}$ ] and intermittent aeration, with a specific gas demand per permeate volume equal to 9.02 $\mathrm{m}^{3}$ gas $/ \mathrm{m}^{3}$ permeate, results in a slower decline and higher value of permeability, ranging from $45 \mathrm{~L} /\left(\mathrm{m}^{2}\right.$.h.bar), in the case with only continuous aeration, to $100 \mathrm{~L} /\left(\mathrm{m}^{2}\right.$.h.bar), with coagulation and intermittent aeration. 
The coagulant produces large, loose particles of solids, and the air scouring decreases the thickness of the surface layer on the MF membrane. These authors chose to operate continuously, with a permeate flux of around $13.3 \mathrm{~L} /\left(\mathrm{m}^{2} . h\right)$, until reaching a maximum TMP of $70 \mathrm{kPa}$ [20]. After 295 hours of operation, they reached a COD concentration of $16 \mathrm{~g} / \mathrm{L}$ with about $70 \%$ of organic matter recovered, thus producing a permeate free of suspended solids and with a low level of SCOD $(\approx 40$ mg/L). Jin et al. [21] had previously investigated a combination involving coagulation, MF and air backflushing. A COD concentration of $15.0 \mathrm{~g} / \mathrm{L}$ was achieved when the system operated with $20 \mathrm{~L} /\left(\mathrm{m}^{2} . \mathrm{h}\right)$, a maximum TMP of $40 \mathrm{kPa}$ and lab-scale continuous operation for a period of 93 hours. Hey et al. [38] assessed preliminary operations before carrying out the DMF of municipal wastewater. As regards the most suitable preliminary treatment, these authors selected a combination of coagulant (aluminum chloride, $15 \mathrm{mg} / \mathrm{L}$ ), anionic flocculants (3 mg/L) and microsieve filtration $(100 \mu \mathrm{m})$ in muni-cipal wastewater before the DMF. The DMF, in turn, was performed by using five flat-sheet membranes $(0.2 \mu \mathrm{m})$ which underwent continuous air scouring [0.69 Nm $\left.3 /\left(\mathrm{m}^{2} . \mathrm{h}\right)\right]$, with intermittent relaxation, under $3 \mathrm{kPa}$ of TMP over a period of 159 hours. Operating under these conditions, these authors reported the fulfillment of the permeate qualities required by European and Swedish directives, besides achieving a moderate value of permeate flux, $6.1 \mathrm{~L} /\left(\mathrm{m}^{2} . h\right)$. The COD concentration in the permeate stream was $41 \mathrm{mg} / \mathrm{L}$. With this treatment, these authors indicated that more carbon was made available for biogas production.

In a similar approach, Delgado Diaz et al. [34] evaluated the effect of previous coagulation/sedimentation in the direct membrane UF of raw municipal wastewater using a membrane with a pore size of $0.03 \mu \mathrm{m}$. The results indicated that besides achieving a high removal of tCOD (80-95\%), the fouling resistance could be reduced by applying an optimal coagulant dose, $0.14-0.16 \mathrm{mM}$ of aluminum chloride, with a 
permeate flux of $23 \mathrm{~L} /\left(\mathrm{m}^{2} . \mathrm{h}\right)$ and a backwashing time of 85 seconds every time a pre-stablished TMP of $36 \mathrm{kPa}$ was reached in the continuous filtration experiment. This strategy allowed each cycle to last between 8.5 and 15 minutes before the backwashing period.

In order to suppress any organic matter degradation through aerobic oxidation, Kimura et al. [22] were able to efficiently control membrane fouling by combining mechanical agitation (300 rpm), vertical vibration of membrane module (20 mm and $3 \mathrm{~Hz}$ of amplitude and frequency, respectively) and a CEB with citric acid $(0.12-1 \% \mathrm{w} / \mathrm{v})$. These authors achieved a 50-fold wastewater up-concentration of about $8 \mathrm{~g} / \mathrm{L}$ after 30 days of operation, approximately, using two PVDF MF membranes at 6.5 and $4.2 \mathrm{~L} /\left(\mathrm{m}^{2} . \mathrm{h}\right)$ of permeate fluxes in two sequentially connected tanks. During the long-term experiment, the TMP was maintained almost all the time at below $10 \mathrm{kPa}$ in both tanks.

The organic concentrations recovered inside the DMF tank are dependent on permeate fluxes, concentrations of COD in the feed stream, total operation time, working volumes of the membrane tank and the frequency at which the purge is performed. Some authors like Gong et al. [23], Lateef et al. [19] and Mezohegyi et al. [36] have reached high organic matter concentrations of $7.5 \mathrm{~g} / \mathrm{L}$ ( $84 \%$ of recovery), $5.0 \mathrm{~g} / \mathrm{L}(75 \%$ of recovery) and $11.4 \mathrm{~g} / \mathrm{L}$ (96.4\% of recovery) of tCOD, respectively, in the mixed liquor. The corresponding systems treated the raw wastewater feed at between 240 and $500 \mathrm{mg} / \mathrm{L}$ of tCOD. These experiments lasted 144, 200 and 20 hours, respectively, and they were performed in tanks with capacities of $300,0.75$ and $1.5 \mathrm{~L}$, respectively.

The strategies and mechanisms adopted in each experiment were different from each other. While Gong et al. concentrated the solids in a single membrane tank with a constant permeate flux of $5 \mathrm{~L} /\left(\mathrm{m}^{2} . h\right)$, Lateef et al. adopted a double 
concentration stage using two identical tanks in series with different volumetric concentration factors and permeate fluxes of 21 and $20.8 \mathrm{~L} /\left(\mathrm{m}^{2} . \mathrm{h}\right)$ and 50 and 16.7 $L /\left(m^{2} . h\right)$, respectively. On the other hand, Mezohegyi et al. also tried two tanks in series, but establishing volumetric concentration factors of 5 and 25, and keeping the same permeate flux of $21.3 \mathrm{~L} /\left(\mathrm{m}^{2} . \mathrm{h}\right)$ for both sequencing tanks. Gong et al., Lateef et al. and Mezohegyi et al. have also applied different techniques in order to control fouling: coagulation/adsorption, CEB and aerated or vibrated membranes, respectively. Having worked with aerated and vibrated membranes, Mezohegyi et al. concluded that vibrated membranes present advantages when considering filtration performance and energy usage, whereas the up-concentration efficiencies for both techniques were identical. The processes permitted the final organic matter upconcentration to reach ratios of 16-, 21- and 23-fold higher than the initial tCOD concentrations, respectively, without compromising the quality of the permeate, which were free of suspended solids in all studied cases, and presented a tCOD content varying between 75 and $84 \mathrm{mg} / \mathrm{L}$.

Despite being a widely used technique for fouling minimization, aeration has proved to be an inconvenient source of losses in the DMF processes, not always enough to make the systems unfeasible, but still somewhat against the idea of energy saving and carbon recovery. Tuyet et al. [35] reached a concentration of $1022 \mathrm{mg} / \mathrm{L}$ of tCOD, 5.4-fold the feed concentration, using direct membrane UF and continuous air scouring as the fouling control. These authors reported losses of up to $46 \%$ of COD and advised the use of another antifouling technique, such as blowing $\mathrm{CO}_{2}$ separated from the digester biogas instead of atmospheric air.

Other authors tried antifouling methods like intermittent aeration, mechanical agitation and crossflow velocity, as indicated in Table 1 [24,37,39-43], and the systems reached between $42 \%$ and $96 \%$ of COD removal. No losses of COD were 
indicated by the authors. Nieuwenhuijzen et al. [39], Ravazzini et al. [40], Bendick et al. [41] and Abdessemed and Nezzal [24], for instance, adopted the DMF in crossflow configuration as a method for wastewater treatment together with intermittent tap water backflush, intermittent demineralized water backflush, air backflush and coagulation/adsorption, respectively. These four authors studied permeate fluxes between 60 and $160 \mathrm{~L} /\left(\mathrm{m}^{2} . \mathrm{h}\right)$, with cross- flow velocities that varied between 1 and $3 \mathrm{~m} / \mathrm{s}$. The authors are in agreement that crossflow velocity, membrane pressure, and the type and concentration of the solid feed are the main variables that affect the permeate flux over time in this type of membrane configuration. Meanwhile, auxiliary anti- fouling methods could significantly improve the DMF performance.

The wide variety of procedures for controlling membrane fouling in order to obtain high solid concentration or a long-term process is, to a certain extent, a limitation when trying to establish a common protocol, or at least the basic parameters of operation to be carried out in the DMF systems. In general, the authors reported a remarkable improvement in membrane permeability together with the achievement of better solid concentration by applying coagulation and/or continuous or intermittent aeration. While the addition of coagulants facilitates the formation of solid aggregates, the intermittent aeration could provide sufficient shear force to detach the cake layer from the surface of the membrane fibers. Carbon oxidation could be avoided if the intermittent aeration is not intense and short enough to disallow the aerobic biological activity. Furthermore, periodic backwash steps with a permeate stream would improve the membrane permeability by providing a decrease in internal fouling. The membrane tank design is another approach to be taken into account. A filtration section of membrane tank separated from a sedimentation section could decrease the concentration of suspended particles on membrane surroundings and, hence, increase the concentration of solids in the sedimentation 
section. Therefore, periodic purges of concentrated solids could be performed in order to maintain a stable concentration inside the membrane tank. Those strategies can enable a feasible process performance in terms of membrane control, optimum organic matter recovery and energy savings.

This brief assessment of the last researches on the DMF process to separate and concentrate COD from municipal wastewater has shown that there is still much room to work on the variables that affect the reliability of the technology. Some aspects have yet to be studied, such as fouling formation and techniques to mitigate membrane fouling, minimization of carbon losses and increase in the permeate flux, since the operating costs depend on it. The further use of the permeate stream is another factor that deserves emphasis. Another biological process would be necessary, depending on the quality of water produced by the DMF. This is the case of medium to high-strength wastewater, whose high SCOD content requires a further biological process in order to be stabilized. On the other hand, the permeate stream produced from low-strength municipal wastewater could be released into water bodies or even used in agriculture irrigation.

Another approach is concerned with membrane cleaning protocols. Membrane cleaning is necessary to restore the initial membrane permeability and also to prevent any damage to the fibers. Since the membrane types and configurations in the DMF process are the same as those applied to the MBR processes, the physical and chemical cleaning methods are basically the same ones. Meanwhile, more intensive procedures might also be performed in order to overcome the severe fouling induced by raw wastewater in DMF. Table 1 indicated the main cleaning methods used for the recovery of the membrane module used in the DMF experiments previously mentioned. Most of the methods include physical cleaning with a soft sponge and/or tap water jet and chemical cleaning with $\mathrm{NaClO}$. Some 
authors reported a great recovery of membrane permeability, but the strategies adopted should be better studied in terms of maintenance costs.

\subsection{Simplified Energy Study on DMF and DMF + AS Processes}

A simplified energy balance has been outlined by comparing the AS process and the DMF followed by the AS process. This study aimed to determine whether the additional energy used for the intensification of the primary treatment, by means of the DMF process in a supposed DMF + AS process, is offset by the lower energy consumed for aeration in the following AS stage, as a result of diminished organic matter content. Additionally, an increase in biogas production is expected as a result of higher available organic content due to the lower loss of organic matter through the AS process.

For both of the systems studied, high-strength municipal wastewater was considered [5], and the main conditions used for dimensioning and estimating the energy balance for AS and DMF + AS are shown in Table 3. For both AS systems, nitrification was considered, and the kinetic para- meters were applied according to Metcalf and Eddy [5]. For the DMF stage, in the DMF + AS process, continuous air scouring was applied to the membrane agitation as an antifouling technique. For the energy balance, the items considered for energy consumption were aeration in the AS and air scouring in the DMF. Energy production was taken from the biogas generated, with an efficiency rate of 35\% for electricity production. No head losses through the air pipes and diffusers were considered. 
Table 3 - Parameters adopted for energy balance of the activated sludge (AS) and direct membrane filtration (DMF) processes

\begin{tabular}{cc}
\hline Activated sludge (AS) & \\
\hline Temperature, ${ }^{\circ} \mathrm{C}$ & 12 \\
Dissolved oxygen in aeration basin, $\mathrm{mg} / \mathrm{L}$ & 2.0 \\
(a)[MLSS], $\mathrm{mg} / \mathrm{L} \mathrm{SST}$ & 3000 \\
(b)SRT, d & 5 \\
(c)Y, g VSS/g bCOD & 0.4 \\
\hline Direct membrane filtration (DMF) & \\
\hline Filtration flux, L/(m².h) & 12 \\
(d)SGDp, $\mathrm{m}^{3}$ air/m $\mathrm{m}^{3}$ permeate & 15 \\
\hline
\end{tabular}

(a) Mixed-liquor suspended solids, (b) SRT: solids retention time, (c) Y: biomass yield, (d) SGDp: specific gas demand per permeate volume.

It was taken into consideration that all quantities of feeding volatile solid sludge (VSS) were completely retained within the membrane tank and conveyed to the anaerobic digestion stage. For the estimation of biogas production, the values of specific methane yield taken into account for primary sludge, retained sludge in DMF and sludge from AS were 340, 323 and $280 \mathrm{~L}\left(\mathrm{CH}_{4}\right) / \mathrm{kgVSS}$, respectively, based on previous empiric studies [33]. Results, presented in Table 4, show that, since membranes retain all amounts of particulate matter in the DMF stage, the AS process has experimented a reduction of $33.3 \%$ in energy expenditure for aeration and a reduction of $57.4 \%$ of the aerobic basin volume compared with the AS process alone. Additionally, the VSS content is completely retained in the DMF stage; thus, the loss of COD through aerobic oxidation is reduced in the AS stage, and the biogas production from solid streams in the DMF + AS process is $78.3 \%$ higher than in an AS system alone. Overall energy expenditure in the DMF + AS process is higher than in the AS process alone, but the increase in biogas production is sufficiently high enough to achieve a more favorable net energy balance. Furthermore, the minor land space required to build the biological reactor is another important advantage. 
Table 4 - Energy comparison between activated sludge (AS) and direct membrane filtration + AS $(\mathrm{DMF}+\mathrm{AS})$ processes

\begin{tabular}{lccc}
\hline & AS & DMF+AS & Enhancement \\
\cline { 2 - 4 } Energy consumption in AS stage $\left(\mathrm{kWh} / \mathrm{m}^{3}\right)$ & 0.18 & 0.12 & $33.3 \%$ \\
Energy consumption in DMF stage $\left(\mathrm{kWh} / \mathrm{m}^{3}\right)$ & - & 0.15 & - \\
Energy production from biogas $\left(\mathrm{kWh} / \mathrm{m}^{3}\right)$ & 0.23 & 0.41 & $78.3 \%$ \\
Volume of AS basin $\left(\mathrm{m}^{3}\right)$ & 17705 & 7551 & $57.4 \%$ \\
\hline
\end{tabular}

When it comes to maximizing the carbon content recovery from wastewater, a new process could be considered in which the AS stage would be replaced by a standalone DMF followed by a mesophilic anaerobic treatment of concentrated solids and a psychrophilic anaerobic treatment of the permeate stream. This system might represent a change of paradigm for municipal wastewater treatment, as the WWTP would be energetically self-sufficient.

\section{Forward osmosis}

FO has been extensively explored in recent years, reaching a high level of applications and improvements. Several applications, like the concentration of dilute industrial wastewater, source water purification, food processing [44], concentration of landfill leachate [45], treatment of complex streams as drilling wastewater [46], direct reuse of potable water [47], aerobic sludge dewatering [48], concentration of anaerobic digester concentrate [49], seawater desalination [50], dehydration and rejection of pharmaceutical compounds [51], power generation by pressure retarded osmosis [52], FO MBR [53] and raw wastewater up-concentration [27,28,54-57], are present in the literature. These processes attest for the high quality of the product generated, low energy expenditure and even energy production, in the case of pressure retarded osmosis [58]. The FO concept was proposed in 1976, but only in 
recent years have the possibilities of its use begun to be studied and, even though large-scale applications are still in development, the researchers have been struggling to place FO as an important technology, contributing to solve the issue of water demand [59]. In the field of wastewater treatment, FO can play an important role, since the FO process can operate with minimal external energy input and can be perfectly integrated with anaerobic technologies for carbon recovery [54]. Ansari et al. [60] have reviewed the integration of FO with other processes in order to enhance the quality of wastewater treatment and carbon recovery. These authors pointed to three commonly used configurations, the aerobic osmotic MBR, anaerobic osmotic MBR and direct FO filtration, all of them operating in submerged mode.

The up-concentration of wastewater using FO has gained notoriety due to its ability to produce the same permeate quality as RO [28] while consuming less power and having a lower proclivity to membrane fouling [46]. Strengths and downsides must be taken into consideration, especially in order to compare the efficiency of this method with other similar technologies. Therefore, the main characteristics of FO for municipal wastewater up-concentration are described as follows. The main operating conditions found in the literature related to membrane characteristics, DS, wastewater pretreatment and permeate flux are shown in Table 5. The COD and solid concentration in the influent and in the mixed liquor after the FO experiments are presented in Table 6. 
Table 5 - Characteristics of forward osmosis (FO) process for municipal wastewater treatment

\begin{tabular}{|c|c|c|c|c|c|c|c|c|c|c|c|}
\hline Matrix & $\begin{array}{l}\text { Membrane } \\
\text { Area }\end{array}$ & Draw solution & $\begin{array}{l}\text { Osmotic } \\
\text { Pressure } \\
\quad \text { (bar) }\end{array}$ & Active layer & $\begin{array}{l}\text { Wastewater pre- } \\
\text { treatment }\end{array}$ & $\begin{array}{c}\text { COD } \\
\text { concentration } \\
\text { factor }\end{array}$ & $\begin{array}{l}\text { Flow rate } \\
\text { (L/min) }\end{array}$ & $\begin{array}{l}\text { Filtration } \\
\quad \text { flux } \\
\mathrm{L} /\left(\mathrm{m}^{2} \cdot \mathrm{h}\right)\end{array}$ & $\begin{array}{l}\text { Crossflow } \\
\text { velocity } \\
(\mathrm{cm} / \mathrm{s})\end{array}$ & $\begin{array}{c}\text { Operating } \\
\text { time before } \\
\text { chemical } \\
\text { cleaning } \\
\end{array}$ & Ref. \\
\hline $\begin{array}{c}\text { CTA } \\
(0.3-1.0 \mathrm{~nm})\end{array}$ & $56 \mathrm{~cm}^{2}$ & $\begin{array}{c}\mathrm{NaCl} \\
(0.2-4.0 \mathrm{M})\end{array}$ & - & Feed solution & Aeration grit chamber & $5.2-6.3$ & $0.5-3.0$ & $5-25$ & - & $25 \mathrm{~h}$ & {$[57]$} \\
\hline $\begin{array}{c}\text { CTA } \\
(0.37 \mathrm{~nm})\end{array}$ & $125 \mathrm{~cm}^{2}$ & $\begin{array}{c}\mathrm{NaCl}(1.27 \mathrm{M}), \\
\text { Sodium acetate } \\
(1.49 \mathrm{M}), \text { EDTA- } \\
2 \mathrm{NA}(0.61 \mathrm{M})\end{array}$ & 60 & Feed solution & Primary settler & 8 & 1.0 & - & 16.7 & $90 \mathrm{~h}$ & {$[61]$} \\
\hline $\begin{array}{c}2 \text { types TFC } \\
\text { layer (AIM } \\
\text { and } \mathrm{HTI})\end{array}$ & $140 \mathrm{~cm}^{2}$ & $\mathrm{NaCl}(2 \mathrm{M})$ & - & Feed solution & $\begin{array}{l}\text { Screening, sand } \\
\text { and grit removal }\end{array}$ & - & 0.260 & $\simeq 6$ & 4.17 & $4 \mathrm{~h}$ & {$[55]$} \\
\hline TFC and CTA & $15 \mathrm{~cm}^{2}$ & $\mathrm{NaCl}(0.6 \mathrm{M})$ & - & Feed solution & $\begin{array}{l}\text { Primary settler and } \\
\text { pre-filtered } 0.2 \mu \mathrm{m}\end{array}$ & - & 120 & $\simeq 6.5$ & - & $50 \mathrm{~h}$ & {$[56]$} \\
\hline CTA & $64.6 \mathrm{~cm}^{2}$ & $\mathrm{NaCl}(0.6 \mathrm{M})$ & 29.2 & $\begin{array}{l}\text { Feed and draw } \\
\text { solution }\end{array}$ & Primarily treated & - & - & 5.4 & 0.14 & $22 \mathrm{~h}$ & {$[27]$} \\
\hline $\begin{array}{c}\text { Spiral } \\
\text { wound/CTA }\end{array}$ & $0.3 \mathrm{~m}^{2}$ & $\mathrm{NaCl}(0,5 \mathrm{M})$ & 23.6 & Feed solution & Primarily treated & 5 & - & 6 & 20 & $17 \mathrm{~d}$ & {$[28]$} \\
\hline
\end{tabular}

The data reflect the better conditions in up-concentration and/or long-term experiments reported by the authors. 
Table 6 - Performance of municipal wastewater treatment by forward osmosis (FO)

\begin{tabular}{|c|c|c|c|c|c|}
\hline \multicolumn{3}{|c|}{ Influent } & \multicolumn{2}{|c|}{ (a)Bulk solution } & \multirow[b]{2}{*}{ Ref. } \\
\hline $\begin{array}{c}\text { tCOD } \\
(\mathrm{mg} / \mathrm{L})\end{array}$ & $\begin{array}{c}\text { TS } \\
(\mathrm{mg} / \mathrm{L})\end{array}$ & $\begin{array}{c}\text { TSS } \\
(\mathrm{mg} / \mathrm{L})\end{array}$ & tCOD/sCOD (mg/L) & $\begin{array}{c}\text { TS } \\
(\mathrm{mg} / \mathrm{L})\end{array}$ & \\
\hline 522 & - & - & 2714.4-3288.6 & - & {$[57]$} \\
\hline $\begin{array}{c}\text { Low/moderate } \\
137 / 356\end{array}$ & - & - & $\begin{array}{c}\text { Low/moderate } \\
982 / 2893\end{array}$ & - & [61] \\
\hline $\begin{array}{c}\text { Raw/(a)MSF/(b)MFP } \\
560 / 410 / 73\end{array}$ & - & $440 / 250 / 0$ & $\begin{array}{c}\text { Rejection (\%) } \\
\text { 100-99/100- } \\
99 / 98-96 \text { of BOD }\end{array}$ & - & {$[55]$} \\
\hline $\begin{array}{c}\text { Settled/filtered } \\
275 / 132\end{array}$ & $603 / 458$ & $68.8 / 0$ & $8089 / 322$ & $7300 / 4110$ & {$[56]$} \\
\hline 533.6 & - & $400-800$ & 1642.3 & - & {$[27]$} \\
\hline 121 & - & - & 2335 & - & {$[28]$} \\
\hline
\end{tabular}

The data reflect the better conditions in up-concentration and/or long-term experiments reported by the authors.

(a) Microsieve filtrate.

(b) Microfiltration permeate.

tCOD: total chemical oxygen demand; TS: total solids concentration; TSS: total suspended solid concentration. 


\subsection{Advantages of FO for Municipal Wastewater Up-Concentration}

\section{Fouling reversibility}

Since FO is not a pressure-driven process, but an osmotically driven process, the cake layer is less severe than in the other membrane-based process. A recent study has concluded that the membrane fouling in FO for municipal wastewater caused a higher flux decline than the osmotic MBR, due to a thicker cake layer, but the cleaning procedure resulted in a more effective recovery of permeability for FO [62].

\section{Easy cleaning procedure}

It is a consequence of the less compact organic fouling layer provided by the natural osmotic pressure. Most of the time, physical cleaning procedures are sufficient to achieve acceptable membrane permeability or even to recover the initial conditions. Otherwise, a low severe chemical cleaning is needed $[63,64]$.

\section{Low energy requirements}

Since the osmotic pressure difference between the semi- permeable membrane layers is the driving force, the energy expenditure to force the water flux is inexistent or negligible, and if the recovery of the DS is not necessary, FO will be more energy efficient than a RO applied to wastewater treatment [65].

\section{Nutrient removal}

The FO membranes not only produce a high-quality water stream but also facilitate and potentiate the nutrient recovery. Nitrogen, and especially phosphorus, has been harvested from several types of wastewater through direct and hybrid FO processes [28,66-68]. The literature reported high efficiency of phosphorus 
recovery, about 99\%, meanwhile nitrogen corresponds to $80-99 \%$, but it depends fundamentally on whether the system operates alone or coupled with another process [60]. FO membranes are also capable of separating trace organic compounds, which are a matter of concern due to their increasing release into water bodies and the negative effects they can cause on the environment [69-71].

\subsection{Disadvantages of FO for Municipal Wastewater Up- Concentration}

\section{Energy expenditure in hybrid systems}

The DS often needs to be recovered by a posttreatment after the FO concentration of raw wastewater. The FO-RO system allows the recovery of the concentrated DS and the permeate water stream, but the electrical consumption increases considerably, resulting in a process with more energy expenditure than a standalone FO [72].

\section{Concentration polarization (CP)}

$\mathrm{CP}$ is classified as external CP (ECP) and internal CP (ICP). The ECP is a phenomenon by which the effective osmotic pressure is reduced either as a result of a high feed solution (FS) concentration in the interface between the bulk of FS and the membrane layer (concentrative ECP) or as a result of low DS concentration in the interface between the bulk of the DS and the membrane layer (dilutive ECP). When the FS is against the support layer, in an asymmetric membrane, water and salts penetrate the pores of the support layer, causing an increase in concentration inside the support layer (concentrative ICP). When the support layer is facing the DS (most used configuration for wastewater up-concentration), the permeate stream causes a decrease of concentration inside the pores of the support layer (dilutive ICP) $[73,74]$. The CP is an unavoidable phenomenon that supposes a reduction of the effective 
osmotic pressure, thus reducing the water production. However, increasing the crossflow velocity, providing turbulence of feed and DSs and choosing the most adequate DS can help to reduce the CP.

\section{Reverse salt flux}

Another downside of FO is the reverse salt flux from the DS to the FS that contributes to the increase in the ICP and to the decrease in the water flux. The solutes from the DS are able to diffuse through the membrane and interact with some sensitive foulant in the FS in an unfavorable manner, thus causing severe FO fouling [75]. Solutes accumulated in the FS can also jeopardize a further biological treatment due to biological inhibition. The risk of such reverse-diffusion-induced-fouling shall be evaluated when selecting the DS for a specific FO application.

\section{Low water flux}

Besides the inherently low water flow, the $\mathrm{CP}$ and the membrane fouling contribute to the decrease in clean water production by FO. The process feasibility depends on the volume of water treated and the energy consumption. Therefore, some actions can be taken in order to increase the water flux: increase the

membrane filtrating area and use of enhanced support layer to mitigate mass transfer limitations, minimizing the draw solution diffusion through the support layer and allowing a minimal internal concentration polarization $[72,76]$. These techniques must be taken into account in order to provide cheaper and more efficient wastewater treatment, as the FO technique is intended to be. 


\section{Accumulation of contaminants in the DS}

The FO membrane does not remove all contaminants from the feed wastewater. Actually, small compounds are able to pass through the membrane and accumulate in the DS. These compounds compromise the quality of the permeate water and induce the fouling formation in the following stages of the DS recovery. This drawback leads to the installation of additional treatments like adsorption with activated carbon, oxidation with ultraviolet and ion exchange [60].

\section{Operating Conditions and Carbon Recovery in FO}

The up-concentration of municipal wastewater by FO is still at an early stage as regards research and assessment of operation behavior, concerning the type of membrane to be used, time of operation, operating conditions and membrane cleaning. The literature reports only a few studies on FO for municipal wastewater upconcentration. All of them were on a small scale and working with a total membrane surface area of between 0.3 and $140 \mathrm{~cm}^{2}$ (Table 5). In the first years of FO development, the cellulose acetate membranes, initially used for the RO process, were tried out as an option for FO treatments. However, the transport limitations were considered a barrier to the further spreading of that membrane material, and later, the development of the cellulose triacetate membrane (CTA) by Hydration Technology Innovations $^{\circledR}$ was well accepted for the FO process, including the municipal wastewater treatment [65]. CTA membranes appeared to be those most frequently used $[27,28,56,61]$, but some authors worked with different types of thin-filmcomposite (TFC) membranes during performance comparison research [55,77]. The membrane orientation is another consensus between the researchers. Since the active layer facing the draw solution (AL-DS) presents more potential for fouling and 
$\mathrm{CP}$, the option in which the active layer is placed facing the feed solution (AL-FS) is the more widely used configuration [65].

The DS is another important parameter and considerably affects the FO performance. According to Shaffer et al. [72], despite all the groups of DS that have been studied in recent years like polyelectrolytes, hydrophilic magnetic nanoparticles, hydrogels and switchable polarity solvents, the most effective choice seems to be the simple inorganic solutes, like sodium chloride $(\mathrm{NaCl})$, due to their capacity to gather high osmotic pressures, low viscosities and high diffusivities which mitigate ICP, besides being inexpensive sub- stances. Ge et al. [78] have also mentioned that an ideal DS should have a smaller molecular weight and low viscosity. As indicated in Table $5, \mathrm{NaCl}$ has been used as the DS by all the authors studied. The crossflow velocities applied ranged from 0.14 to $20 \mathrm{~cm} / \mathrm{s}$, and most of the permeate fluxes were similar among the cases studied, at 5.4-6.5 L/( $\left.\mathrm{m}^{2} . \mathrm{h}\right)$. A schematic representation of the FO process is shown in Figure 3. The figure shows a process with hypothetical DS recovery represented by the red box 1 "reverse osmosis"; meanwhile, DS storage is indicated by the tank in the red box 2 "draw solution storage". In place of a storage tank, the process could operate with continuous fresh seawater feeding as DS. However, in this work, all the cases studied were setup using a storage tank containing concentrated $\mathrm{NaCl}$ DS.

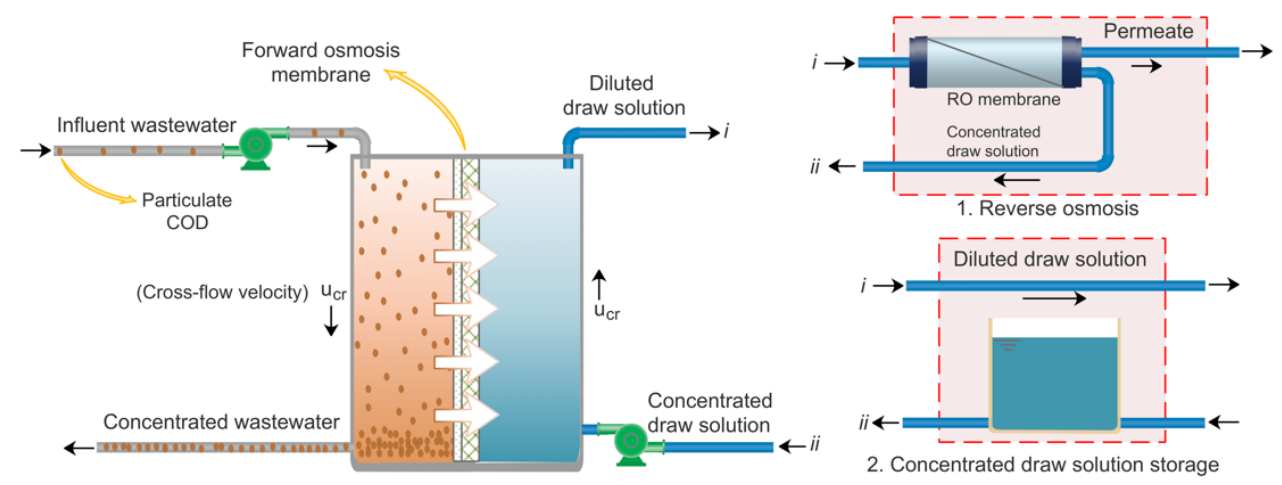

Figure 3 - (1) Forward osmosis with draw solution recovery and (2) without draw solution recovery. 
Ansari et al. [61] have demonstrated the feasibility of using FO to concentrate low- and medium-strength municipal wastewater into an adequate organic load for anaerobic digestion. These authors achieved an eightfold tCOD concentration, reaching final values of 0.982 and $2.9 \mathrm{~g} / \mathrm{L}$ of tCOD from the concentration of lowand medium-strength pre-settled wastewaters, respectively, using a CTA membrane (0.37 nm), at $6 \mathrm{MPa}$ (60 bars) of osmotic pressure and using $\mathrm{NaCl}$ as a DS. The authors also called attention to the salinity buildup in the FS, which is a hindrance to the posterior anaerobic biodegradation of organic matter. For this reason, instead of $\mathrm{NaCl}$, ionic organic draw solutes have been tested and, as a result, sodium acetate and ethylenediaminetetraacetic acid disodium (EDTA-2Na) showed high final tCOD concentration without significantly increasing the conductivity of the FS. According to these authors, the lower reverse fluxes of sodium acetate and EDTA-2Na are ascribed to the larger size and, therefore, lower diffusivity of these ions compared to the $\mathrm{NaCl}$. In addition, the membrane fouling was easily removed by membrane flushing, proving the effectiveness of the physical cleaning strategy.

Hey et al. [55] studied the effect of different preliminary treatments of municipal wastewater in FO process behavior. The aim of these authors was to enhance the wastewater treatment instead of concentrating the particulate COD. A pilot plant composed of three mechanical pretreatments steps, screening/sand trap, microsieving (after screening) and MF (after screening + microsieving), were used to reduce the suspended solid content and improve the direct FO treatment afterwards. A $2 \mathrm{M} \mathrm{NaCl}$ DS was used to generate the driving force through the membranes tested. The initial water flux was set to around $6 \mathrm{~L} /\left(\mathrm{m}^{2} . \mathrm{h}\right)$ with a cross-flow velocity of 4.17 $\mathrm{cm} / \mathrm{s}$ and operation time of $4.5 \mathrm{~h}$, approximately. These authors compared two types of flat- sheet TFC membranes: the Aquaporin InsideTM Membrane (AIM) and the HTI membrane. The AIM membrane showed a slightly better performance in terms of 
presenting a relatively lower decline of the permeate flux (25\% for AIM membrane compared to $43 \%$ for $\mathrm{HTI}$ membrane), as a consequence of low fouling propensity, and similar high solute removal for all scenarios studied, from raw to MF preliminary treated wastewater. About $100 \%$ of the organic matter and more than $97 \%$ of the phosphorus content were rejected.

Ortega-Bravo et al. [56] compared the behavior of a TFC and two different CTA membranes for municipal wastewater up-concentration. The sewage concentration was per- formed with a TFC membrane and $0.6 \mathrm{M} \mathrm{NaCl}$, with initial water fluxes of 5.5 and $6.5 \mathrm{~L} /\left(\mathrm{m}^{2} . \mathrm{h}\right)$, approximately, for the up-concentration of pre-settled sewage and pre-settled-filtered $(0.2 \mu \mathrm{m})$ sewage, respectively. After 50 hours of operation, about $8.1 \mathrm{~g} / \mathrm{L}$ and $322 \mathrm{mg} / \mathrm{L}$ of tCOD was reached for pre-settled and pre-settled-filtered sewage, respectively. Preliminary tests carried out also indicated that the TFC membrane presented low membrane fouling and higher water flux by using the presettled sewage as FS and different concentrations of $\mathrm{NaCl}$ as the DS. The results are in accordance with the conclusions reported by Shaffer et al. [72] and Corzo et al. [77].

Zhang et al. [27] tested the propensity of fouling formation in the CTA membrane using the membrane module on AL-FS and AL-DS configurations. The experiment was performed with an average water flux of $5.4 \mathrm{~L} /\left(\mathrm{m}^{2} . h\right)$, a DS of $0.6 \mathrm{M}$ $\mathrm{NaCl}, 0.14 \mathrm{~cm} / \mathrm{s}$ of crossflow velocity in each side of the membrane, 29.2 bars of osmotic pressure and at a room temperature of $22^{\circ} \mathrm{C}$. After 22 hours of operation, the authors reached a tCOD up-concentration from $533.6 \mathrm{mg} / \mathrm{L}$ to $1.6 \mathrm{~g} / \mathrm{L}$. Comparing the two active layer positions, the AL-FS was less sensitive to fouling formation. According to the authors, this could be attributed to the smoother characteristic of the functional layer, while the support layer had a rougher surface. A CTA membrane $\left(0.3 \mathrm{~m}^{2}\right)$ was also used on a pilot-scale by Wang et al. [28]. The 
experiment was conducted using $0.5 \mathrm{M} \mathrm{NaCl}$ as a DS, with a water flux of $6 \mathrm{~L} /\left(\mathrm{m}^{2} . \mathrm{h}\right)$ and $20 \mathrm{~cm} / \mathrm{s}$ of cross-flow velocity (more details in Table 5). The operation was maintained for 51 days, applying chemical cleaning whenever the water flux was decreased to half of its initial value. An up- concentration from 121 to $2335 \mathrm{mg} / \mathrm{L}$ of tCOD was achieved at the end of the experiment, and about $99.7 \%$ of the phosphorus content was recovered by the process.

\section{Dynamic membrane}

Unlike other membrane processes, the DM takes advantage of a biological layer formed on a support material to filter and separate suspended solids from the wastewater. Support materials such as meshes, ceramic, woven and nonwoven fabrics have been applied to wastewater treatment over the last years [79]. These materials are cheap, compared with MF and UF membranes, and as long as the membrane fouling is controlled, the process could be operated with a low frequency of cleaning. In any case, physical cleaning is usually sufficient to remove excess biofilm and restore the membrane permeability. A schematic representation of DM for the up-concentration of municipal wastewater reported in literature with an optional coagulant dosage (red box 1) is shown in Figure 4.

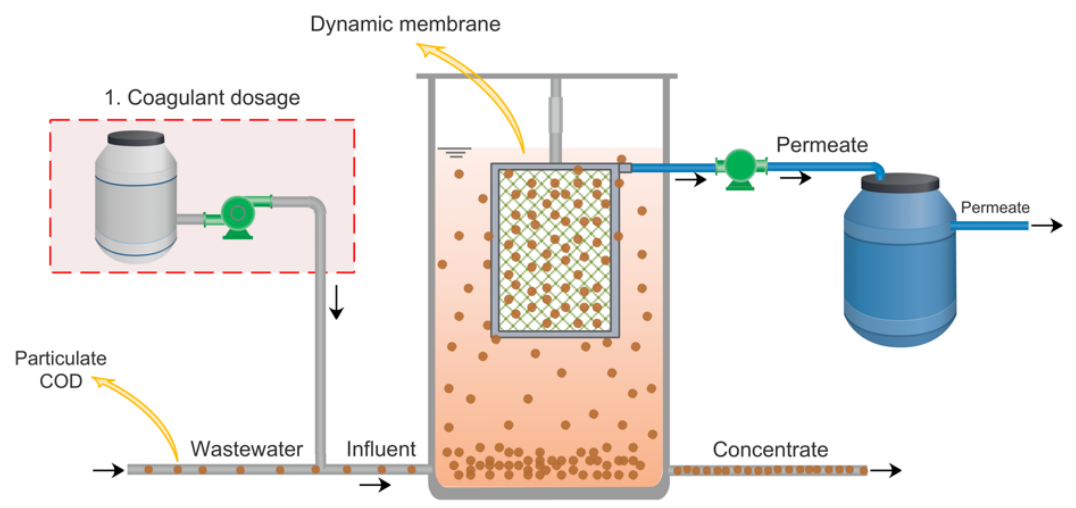

Figure 4 - Dynamic membrane with coagulant dosage as a method to enhance solid concentration 
In recent years, the amount of research on DM for wastewater treatment has considerably increased, especially for aerobic and anaerobic processes, in order to substitute or improve MBR systems $[80,81]$. However, as far as the authors know, the use of DM as a tool for direct wastewater up-concentration for a forward carbon recovery from both water and solid streams has only been reported by Gong et al. [82] and Ma et al. [26] (see Tables 7 and 8). Gong et al. worked with a flat-sheet double-layer cloth-media membrane module measuring $50 \mu \mathrm{m}$ (inner layer) and $1 \mu \mathrm{m}$ (outer layer). According to the authors, a rapid DM formation was observed and, as a result, the permeate fluxes decreased from 10 to less than $2 \mathrm{~L} /\left(\mathrm{m}^{2} . h\right)$, with an average flux of $2.4 \mathrm{~L} /\left(\mathrm{m}^{2} . \mathrm{h}\right)$ based on the integration of fluxes. The operation lasted 70 hours, conducting physical cleaning every 8 hours of operation as a strategy to control fouling. At the end of the experiment, the authors reached $70.1 \%$ of tCOD recovery, with a mixed liquor up-concentration from $700 \mathrm{mg} / \mathrm{L}$ to $4.5 \mathrm{~g} / \mathrm{L}$ of tCOD. Ma et al. also reached a similar recovery value of $\mathrm{tCOD}$, about $81.6 \%$, but with a very high concentration of tCOD, from $257 \mathrm{mg} / \mathrm{L}$ to $32.5 \mathrm{~g} / \mathrm{L}$ and $60 \mathrm{~L} /\left(\mathrm{m}^{2} . \mathrm{h}\right)$ of membrane flux, over a total time of 300 days of operation and with a SPC of $0.24 \mathrm{kWh} / \mathrm{m}^{3}$. These results were made possible by integrating four flat-sheet DMs (61 $\mu \mathrm{m}$ pore size) inside an upflow tank together with a previous coagulation (polyferric sulfate) of the raw wastewater feed. Moreover, the authors performed a physical cleaning operation out of place whenever $35 \mathrm{kPa}$ of TMP was reached. 
Table 7 - Characteristics of dynamic membrane (DM) process for municipal wastewater treatment

\begin{tabular}{|c|c|c|c|c|c|c|c|c|c|c|}
\hline $\begin{array}{c}\text { Material/ } \\
\text { configuration }\end{array}$ & $\begin{array}{l}\text { Pore size mesh } \\
\qquad(\mu \mathrm{m})\end{array}$ & $\begin{array}{l}\text { Total filtration } \\
\text { area }\left(\mathrm{m}^{2}\right)\end{array}$ & $\begin{array}{c}\text { Tank volume } \\
\text { (L) }\end{array}$ & $\begin{array}{l}\text { Wastewater } \\
\text { Pre-treatment }\end{array}$ & $\begin{array}{l}\text { Filtration Flux } \\
\qquad /\left(m^{2} . h\right)\end{array}$ & $\begin{array}{l}\text { HRT } \\
\text { (h) }\end{array}$ & $\begin{array}{l}\text { TMP } \\
(\mathrm{kPa})\end{array}$ & $\begin{array}{c}\text { Operating } \\
\text { time before } \\
\text { physical } \\
\text { cleaning } \\
\end{array}$ & $\begin{array}{l}\text { Matrix } \\
\text { cleaning }\end{array}$ & Ref. \\
\hline $\begin{array}{l}\text { Dacron-Propene/ } \\
\text { Flat-sheet, double } \\
\text { layer }\end{array}$ & $\begin{array}{c}50 \text { (inner layer) } \\
1 \text { (outer layer) }\end{array}$ & 0.023 & 10 & Raw wastewater & 2.4 & - & 80 & $8 \mathrm{~h}$ & $\begin{array}{c}\text { Physical } \\
\text { cleaning } \\
\text { (out of place) }\end{array}$ & {$[82]$} \\
\hline $\begin{array}{l}\text { Dacron mesh/ } \\
\text { flat-sheet }\end{array}$ & $61 \mu \mathrm{m}$ & 0.32 & 42 & $\begin{array}{c}\text { Coagulation } \\
\text { (polyferric sulfate, } \\
50 \mathrm{mg} / \mathrm{L} \text { ) }\end{array}$ & 60 & 2.2 & 35 & $35 d$ & $\begin{array}{c}\text { Physical } \\
\text { cleaning with } \\
\text { tap water (out } \\
\text { of place) }\end{array}$ & {$[26]$} \\
\hline
\end{tabular}

The data reflect the better conditions in up-concentration and/or long-term experiments reported by the authors.

Table 8 - Performance of municipal wastewater treatment by dynamic membrane (DM)

\begin{tabular}{|c|c|c|c|c|c|c|c|}
\hline \multicolumn{2}{|c|}{ Influent } & \multicolumn{2}{|c|}{ Mixed Liquor } & \multicolumn{2}{|c|}{ Lower section } & \multirow{2}{*}{$\begin{array}{c}\text { Effluent } \\
\text { tCOD/sCOD } \\
(\mathrm{mg} / \mathrm{L})\end{array}$} & \multirow[b]{2}{*}{ Ref. } \\
\hline $\begin{array}{c}\mathrm{tCOD} / \mathrm{sCOD} \\
(\mathrm{mg} / \mathrm{L})\end{array}$ & TSS (mg/L) & $\begin{array}{c}\mathrm{tCOD} / \mathrm{sCOD} \\
(\mathrm{mg} / \mathrm{L})\end{array}$ & $\begin{array}{c}\text { TSS } \\
(\mathrm{mg} / \mathrm{L})\end{array}$ & $\begin{array}{c}\text { tCOD/sCOD } \\
(\mathrm{g} / \mathrm{L})\end{array}$ & $\begin{array}{l}\text { TSS } \\
(\mathrm{g} / \mathrm{L})\end{array}$ & & \\
\hline 615 / - & 400 & 4500 & 4000 & - & - & 139 & [82] \\
\hline $256.9 / 81.9$ & - & $135.5 / 36.7$ & 101.1 & $32.5 / 0.301$ & 27.1 & 76.2 & [26] \\
\hline
\end{tabular}

The data reflect the better conditions in up-concentration and/or long-term experiments reported by the authors. 
Although remarkable results have been achieved in these two papers on DM, the up-concentration of raw wastewater using this technology is still at an infant stage. DM is a feasible and potential technology, but further efforts may be made to ensure a higher organic content recovery in order to reach the same advantages as the other membrane-based processes. Moreover, since the DM layer is formed from the organic substances present in the filtered wastewater, such as suspended solids and extracellular polymeric substances, the biomass accumulated is high and, depending on the environmental conditions, the COD content could be degraded, as in the case of the self-forming DM bioreactor [83] and, as a consequence, a significant carbon loss could take place.

\section{Future considerations and recommendations}

Even though the interest in membrane-based processes for wastewater upconcentration has increased in recent years, the small scale and the short operating time of the experiments performed have led to one-off or inconclusive results. These results are still insufficient for overcoming classic problems like low water fluxes and membrane fouling, and further enhancements are still required in order to apply these technologies on a large scale. Therefore, further assessment of the membranebased process should consider long-term and larger-scale experiments in order to provide a better understanding of membrane behavior and reliable values for COD and energy balances.

Regarding the antifouling techniques in DMF, coagulation/flocculation needs further enhancement in order to reach a solid recovery value that is high enough to outperform the cost of coagulant/flocculant purchase and to ensure that this type of product does not cause a negative effect on the long-term operation of the membrane. 
Furthermore, air or gas scouring should not be over- looked. An intermittent, moderate aeration could prevent the formation of fouling on the membrane surface without inducing biological oxidation. Other techniques like mechanical agitation, vibration and an adequate backflush, with permeate, chemical or air flux, could be integrated into the process, while considering energy costs. Moreover, experiments on DMF should establish adequate filtration cycle times, taking into account the importance of backwash to the reversible and irreversible fouling resistance reduction. Another noteworthy point is the solid concentration inside the membrane tank. A high solid concentration has a direct influence on membrane resistance and, therefore, on permeate fluxes. Hence, experiments should consider peri- odic purges of concentrated solids. An improved membrane tank configuration is another important parameter which could enhance solid sedimentation and, at the same time, allow less membrane fouling. In the same way, the feeding point should be considered in order to diminish the concentration of suspended solids on the surrounding membrane module. Most of these techniques should be carried out together, allowing a better control of membrane fouling and, consequently, increasing the membrane permeability and reaching a better result of solid up-concentration.

Regarding FO, there are only few papers on literature related to the upconcentration of municipal wastewater by FO, and they have indicated that $\mathrm{CP}$ phenomenon is still a concern. Besides the need to carry out more experiments, the membrane materials and structures should be better studied in order to reduce CP problems. TFC membranes have been pointed out as an alternative to CTA membranes due to lower membrane fouling and higher water fluxes; however, further studies need to be performed, taking into consideration problems with reverse solute fluxes, economic benefits and membrane replacement needs. The crossflow velocity remains an important parameter to be explored with regard to controlling membrane 
fouling and ECP and is an important variable for maintaining the osmotic pressure between the feed and DSs. FO could be placed as a cheaper alternative to conventional wastewater treatment, but its feasibility is heavily dependent on whether the DS is regen- erated or not. If the FO plant is placed in coastal areas, the seawater could be continuously collected and renewed as a DS, but if not, the DS recovery must be carried out, most of the times by $\mathrm{RO}$, which is likely to convert the FO into an unfeasible process, from an economic point of view.

A recent energy comparison between $\mathrm{FO}(2 \mathrm{M} \mathrm{NaCl} \mathrm{DS})$ without the regeneration of DS and DMF with previous coagulation/flocculation and microsieving filtration was carried out by Hey et al. [84]. As an overall result, both technologies showed similar values of energy consumption and production by means of methane generated through anaerobic digestion of concentrated solids. However, it is important to continue with energy balances in order to ensure more results and the economic feasibility of these technologies. The selection of DS is another important parameter to take into account. The influence of using monovalent or divalent cations could be important in the reverse salt flux and in the consequent interactions with the FS while contributing or not to the fouling of the membrane. The organic DS could help to reduce the salt reverse flux, although these solutions are usually more expensive than the inorganic solutions. The use of hypersaline wastewater, as the effluent from table olive processing or brine from seawater desalination, for example, should be better studied as DSs for municipal wastewater up-concentration, taking example from recently published works which apply these DSs for AS concentration and enrichment of nutrients from treated municipal wastewater $[85,86]$.

The DM is still in an initial experimental stage for municipal wastewater upconcentration, but the cheaper material for the DM layer formation, easy cleaning procedure and relatively high membrane fluxes are attractive advantages over DMF 
and FO and deserve attention. Some aspects, like the mechanisms of DM formation, have to be better understood in order to establish the optimum operating conditions relating to parameters such as permeate fluxes and also to develop strategies to avoid and reduce losses through COD oxidation. The quality of the DM layer is another factor that directly affects the permeate quality and the process itself. On other hand, the process of mem- brane cleaning should be better studied, considering both the possible procedures and frequency. Great results for solid up-concentration from municipal wastewater have been found in literature, and future research on this area must be encouraged.

\section{Conclusions}

Membrane-based technologies have been widely considered in order to replace conventional systems for treating municipal wastewater. The ability to efficiently separate and concentrate the particulate content from municipal wastewater leads to a complete conversion of available organic matter into biogas throughout anaerobic treatments. DMF and, to a lesser degree, FO and DMs, has been recently studied, and the results have encouraged further studies into improving variables that affect the operation and economics of these technologies, such as water flux, membrane fouling and membrane cleaning. These technologies will most likely be required in the future as standalone or combined treatments for sustainable WWTPs, and efforts should be made toward their better comprehension, development and feasibility of the processes. A simplified energy balance has shown that a combined DMF and AS process is economically feasible and outweighs a standalone AS process in terms of biogas production and land area requirement. Future works should concentrate on a complete economical overview of all the technologies discussed, 
taking into consideration both operating costs and energy recovery through biogas production.

\section{Acknowledgments}

The authors gratefully acknowledge the support provided by the Environmental Technology group (UIC - 071) of the Universidad de Valladolid. Thiago Antonio would like to thank the Conselho Nacional de Desenvolvimento Científico e Tecnológico (CNPq, National Council for the Scientific and Technological Development - Brazil) for his PhD scholarship.

\section{Funding}

This work was supported by the Conselho Nacional de Desenvolvimento Científico e Tecnológico [234006/2014-5].

\section{References}

[1] P.L. McCarty, J. Bae, J. Kim, Domestic wastewater treatment as a net energy producer-can this be achieved?, Environ. Sci. Technol. 45 (2011) 7100-7106. doi:10.1021/es2014264.

[2] J.M. Garrido, M. Fdz-Polanco, F. Fdz-Polanco, Working with energy and mass balances: A conceptual framework to understand the limits of municipal wastewater treatment, Water Sci. Technol. 67 (2013) 2294-2301. doi:10.2166/wst.2013.124.

[3] V.G. Gude, Energy and water autarky of wastewater treatment and power generation systems, Renew. Sustain. Energy Rev. 45 (2015) 52-68. doi:10.1016/j.rser.2015.01.055.

[4] I. Shizas, D.M. Bagley, Experimental Determination of Energy Content of Unknown Organics in Municipal Wastewater Streams, J. Energy Eng. 130 (2004) 45-53. doi:10.1061/(ASCE)07339402(2004)130:2(45).

[5] E. Metcalf, H. Eddy, Wastewater engineering: treatment and reuse, 4th ed., McGraw-Hill, New York, 2003.

[6] E. Dulekgurgen, S. Doğruel, Ö. Karahan, D. Orhon, Size distribution of wastewater COD fractions as an index for biodegradability, Water Res. 40 (2006) 273-282. doi:10.1016/j.watres.2005.10.032.

[7] J. Wu, G. Yan, G. Zhou, T. Xu, Wastewater COD biodegradability fractionated by simple physicalchemical analysis, Chem. Eng. J. 258 (2014) 450-459. doi:10.1016/j.cej.2014.07.106.

[8] X. Hao, R. Liu, X. Huang, Evaluation of the potential for operating carbon neutral WWTPs in 
China, Water Res. 87 (2015) 424-431. doi:10.1016/j.watres.2015.05.050.

[9] F. Fdz-Polanco, R. Velazquez, S.I. Perez-Elvira, C. Casas, D. del Barrio, F.J. Cantero, M. FdzPolanco, P. Rodriguez, L. Panizo, J. Serrat, P. Rouge, Continuous thermal hydrolysis and energy integration in sludge anaerobic digestion plants, Water Sci. Technol. 57 (2008) 1221-1226. doi:10.2166/wst.2008.072.

[10] R. Cano, S.I. Pérez-Elvira, F. Fdz-Polanco, Energy feasibility study of sludge pretreatments: A review, Appl. Energy. 149 (2015) 176-185. doi:10.1016/j.apenergy.2015.03.132.

[11] P. Jenicek, J. Kutil, O. Benes, V. Todt, J. Zabranska, M. Dohanyos, Energy self-sufficient sewage wastewater treatment plants: Is optimized anaerobic sludge digestion the key?, Water Sci. Technol. 68 (2013) 1739-1743. doi:10.2166/wst.2013.423.

[12] J.A. Álvarez, E. Armstrong, M. Gomez, M. Soto, Anaerobic treatment of low-strength municipal wastewater by a two-stage pilot plant under psychrophilic conditions, Bioresour. Technol. 99 (2008) 7051-7062. doi:10.1016/j.biortech.2008.01.013.

[13] S. Chong, T.K. Sen, A. Kayaalp, H.M. Ang, The performance enhancements of upflow anaerobic sludge blanket (UASB) reactors for domestic sludge treatment - A State-of-the-art review, Water Res. 46 (2012) 3434-3470. doi:10.1016/j.watres.2012.03.066.

[14] B. Lew, I. Lustig, M. Beliavski, S. Tarre, M. Green, An integrated UASB-sludge digester system for raw domestic wastewater treatment in temperate climates, Bioresour. Technol. 102 (2011) 4921-4924. doi:10.1016/j.biortech.2011.01.030.

[15] M. Takahashi, T. Yamaguchi, Y. Kuramoto, A. Nagano, S. Shimozaki, H. Sumino, N. Araki, S. Yamazaki, S. Kawakami, H. Harada, Performance of a pilot-scale sewage treatment: An up-flow anaerobic sludge blanket (UASB) and a down-flow hanging sponge (DHS) reactors combined system by sulfur-redox reaction process under low-temperature conditions, Bioresour. Technol. 102 (2011) 753-757. doi:10.1016/j.biortech.2010.08.081.

[16] J. Hoinkis, S.A. Deowan, V. Panten, A. Figoli, R.R. Huang, E. Drioli, Membrane Bioreactor (MBR) Technology - a Promising Approach for Industrial Water Reuse, Procedia Eng. 33 (2012) 234241. doi:10.1016/j.proeng.2012.01.1199.

[17] N.S.A. Mutamim, Z.Z. Noor, M.A.A. Hassan, G. Olsson, Application of membrane bioreactor technology in treating high strength industrial wastewater: a performance review, Desalination. 305 (2012) 1-11. doi:10.1016/j.desal.2012.07.033.

[18] A. Santos, W. Ma, S.J. Judd, Membrane bioreactors: Two decades of research and implementation, Desalination. 273 (2011) 148-154. doi:10.1016/j.desal.2010.07.063.

[19] S.K. Lateef, B.Z. Soh, K. Kimura, Direct membrane filtration of municipal wastewater with chemically enhanced backwash for recovery of organic matter, Bioresour. Technol. 150 (2013) 149-155. doi:10.1016/j.biortech.2013.09.111.

[20] Z. Jin, H. Gong, H. Temmink, H. Nie, J. Wu, J. Zuo, K. Wang, Efficient sewage pre-concentration with combined coagulation microfiltration for organic matter recovery, Chem. Eng. J. 292 (2016) 130-138. doi:10.1016/j.cej.2016.02.024.

[21] Z. Jin, H. Gong, K. Wang, Application of hybrid coagulation microfiltration with air backflushing to direct sewage concentration for organic matter recovery, J. Hazard. Mater. 283 (2015) 824831. doi:10.1016/j.jhazmat.2014.10.038. 
[22] K. Kimura, D. Honoki, T. Sato, Effective physical cleaning and adequate membrane flux for direct membrane filtration (DMF) of municipal wastewater: Up-concentration of organic matter for efficient energy recovery, Sep. Purif. Technol. 181 (2017) 37-43. doi:10.1016/j.seppur.2017.03.005.

[23] H. Gong, Z. Jin, X. Wang, K. Wang, Membrane fouling controlled by coagulation/adsorption during direct sewage membrane filtration (DSMF) for organic matter concentration, J. Environ. Sci. (China). 32 (2015) 1-7. doi:10.1016/j.jes.2015.01.002.

[24] D. Abdessemed, G. Nezzal, Treatment of primary effluent by coagulation-adsorptionultrafiltration for reuse, Desalination. 152 (2002) 367-373.

[25] V. Diamantis, P. Melidis, A. Aivasidis, Efficiency and Sustainability of Urban Wastewater Treatment with Maximum Separation of the Solid and Liquid Fraction, in: S.N. Agathos (Ed.), Compr. Biotechnol., 2nd ed., Elsevier B.V., Amsterdam, 2011: pp. 507-515. doi:10.1016/B978-0-08-088504-9.00388-3.

[26] J. Ma, Z. Wang, Y. Xu, Q. Wang, Z. Wu, A. Grasmick, Organic matter recovery from municipal wastewater by using dynamic membrane separation process, Chem. Eng. J. 219 (2013) 190199.

[27] X. Zhang, Z. Ning, D.K. Wang, J.C. Diniz da Costa, Processing municipal wastewaters by forward osmosis using CTA membrane, J. Memb. Sci. 468 (2014) 269-275. doi:10.1016/j.memsci.2014.06.016.

[28] Z. Wang, J. Zheng, J. Tang, X. Wang, Z. Wu, A pilot-scale forward osmosis membrane system for concentrating low-strength municipal wastewater: performance and implications, Sci. Rep. 6 (2016) 21653. doi:10.1038/srep21653.

[29] A. Mels, Physical-chemical pretreatment as an option for increased sustainability of municipal wastewater treatment plants, 2001.

[30] M.G. Buonomenna, J. Bae, Membrane processes and renewable energies, Renew. Sustain. Energy Rev. 43 (2015) 1343-1398. doi:10.1016/j.rser.2014.11.091.

[31] W. Verstraete, S.E. Vlaeminck, ZeroWasteWater: short-cycling of wastewater resources for sustainable cities of the future, Int. J. Sustain. Dev. World Ecol. 18 (2011) 253-264. doi:10.1080/13504509.2011.570804.

[32] S.J. Judd, Membrane technology costs and me, Water Res. 122 (2017) 1-9. doi:10.1016/j.watres.2017.05.027.

[33] T.A. Nascimento, F.R. Mejía, F. Fdz-Polanco, M. Peña, Improvement of municipal wastewater pretreatment by direct membrane filtration, Environ. Technol. 38 (2017) 2562-2572. doi:10.1080/09593330.2016.1271017.

[34] S. Delgado Diaz, L. Vera Peña, E. González Cabrera, M. Martínez Soto, L.M. Vera Cabezas, L.R. Bravo Sánchez, Effect of previous coagulation in direct ultrafiltration of primary settled municipal wastewater, Desalination. 304 (2012) 41-48. doi:10.1016/j.desal.2012.08.005.

[35] N.T. Tuyet, N.P. Dan, N.C. Vu, N.L.H. Trung, B.X. Thanh, H. De Wever, M. Goemans, L. Diels, Laboratory-scale membrane up-concentration and co-anaerobic digestion for energy recovery from sewage and kitchen waste, Water Sci. Technol. 73 (2016) 597-606. doi:10.2166/wst.2015.535. 
[36] G. Mezohegyi, M.R. Bilad, I.F.J. Vankelecom, Direct sewage up-concentration by submerged aerated and vibrated membranes, Bioresour. Technol. 118 (2012) 1-7. doi:10.1016/j.biortech.2012.05.022.

[37] K.-H. Ahn, K.-G. Song, I.-T. Yeom, K.-Y. Park, Performance comparison of direct membrane separation and membrane bioreactor for domestic wastewater treatment and water reuse, Water Sci. Technol. Water Supply. 1 (2001) 315-323.

[38] T. Hey, J. Väänänen, N. Heinen, J. la Cour Jansen, K. Jönsson, Potential of combining mechanical and physicochemical municipal wastewater pre-treatment with direct membrane filtration, Environ. Technol. 38 (2016) 108-115. doi:10.1080/09593330.2016.1186746.

[39] A.F. van Nieuwenhuijzen, H. Evenblij, J.H.J.M. van der Graaf, Direct wastewater membrane filtration for advanced particle removal from raw wastewater, in: H.H. Hahn, E. Hoffmann, H. Ødegaard (Eds.), Chem. Water Wastewater Treat. VI, Springer-Verlag, Berlin, 2000: pp. 235244. doi:10.1007/978-3-642-59791-6.

[40] A.M. Ravazzini, A.F. van Nieuwenhuijzen, J.H.M.J. van der Graaf, Direct ultrafiltration of municipal wastewater: Comparison between filtration of raw sewage and primary clarifier effluent, Desalination. 178 (2005) 51-62. doi:10.1016/j.desal.2004.11.028.

[41] J.A. Bendick, C.J. Miller, B.J. Kindle, H.F. Shan, R.D. Vidic, R.D. Neufeld, Pilot scale demonstration of cross-flow ceramic membrane microfiltration for treatment of combined and sanitary sewer overflows, J. Environ. Eng. 131 (2005) 1532-1539. doi:10.1061/(ASCE)07339372(2005)131:11(1532).

[42] G. Ramon, M. Green, R. Semiat, C. Dosoretz, Low strength graywater characterization and treatment by direct membrane filtration, Desalination. 170 (2004) 241-250. doi:10.1016/j.desal.2004.02.100.

[43] V.I. Diamantis, I. Antoniou, P. Melidis, A. Aivasidis, Direct Membrane Filtration of Sewage Using Aerated Flat- Sheet Membranes, Proc. 11th Int. Conf. Environ. Sci. Technol. (2009) 3-5.

[44] T.Y. Cath, A.E. Childress, M. Elimelech, Forward osmosis: Principles, applications, and recent developments, J. Memb. Sci. 281 (2006) 70-87. doi:10.1016/j.memsci.2006.05.048.

[45] J. Li, A. Niu, C.J. Lu, J.H. Zhang, M. Junaid, P.R. Strauss, P. Xiao, X. Wang, Y.W. Ren, D.S. Pei, A novel forward osmosis system in landfill leachate treatment for removing polycyclic aromatic hydrocarbons and for direct fertigation, Chemosphere. 168 (2017) 112-121. doi:10.1016/j.chemosphere.2016.10.048.

[46] B.D. Coday, P. Xu, E.G. Beaudry, J. Herron, K. Lampi, N.T. Hancock, T.Y. Cath, The sweet spot of forward osmosis: Treatment of produced water, drilling wastewater, and other complex and difficult liquid streams, Desalination. 333 (2014) 23-35. doi:10.1016/j.desal.2013.11.014.

[47] N.T. Hancock, P. Xu, M.J. Roby, J.D. Gomez, T.Y. Cath, Towards direct potable reuse with forward osmosis: Technical assessment of long-term process performance at the pilot scale, J. Memb. Sci. 445 (2013) 34-46. doi:10.1016/j.memsci.2013.04.056.

[48] N.C. Nguyen, S.S. Chen, H.Y. Yang, N.T. Hau, Application of forward osmosis on dewatering of high nutrient sludge, Bioresour. Technol. $132 \quad$ (2013) 224-229. doi:10.1016/j.biortech.2013.01.028.

[49] R.W. Holloway, A.E. Childress, K.E. Dennett, T.Y. Cath, Forward osmosis for concentration of 
anaerobic digester centrate, Water Res. $41 \quad$ (2007) 4005-4014. doi:10.1016/j.watres.2007.05.054.

[50] N. Akther, A. Sodiq, A. Giwa, S. Daer, H.A. Arafat, S.W. Hasan, Recent advancements in forward osmosis desalination : A review, Chem. Eng. J. 281 (2015) 502-522.

[51] X. Jin, J. Shan, C. Wang, J. Wei, C.Y. Tang, Rejection of pharmaceuticals by forward osmosis membranes, J. Hazard. Mater. 227-228 (2012) 55-61. doi:10.1016/j.jhazmat.2012.04.077.

[52] D.I. Kim, J. Kim, H.K. Shon, S. Hong, Pressure retarded osmosis (PRO) for integrating seawater desalination and wastewater reclamation: Energy consumption and fouling, J. Memb. Sci. 483 (2015) 34-41. doi:10.1016/j.memsci.2015.02.025.

[53] A. Achilli, E.A. Marchand, The forward osmosis membrane bioreactor: A low fouling alternative to MBR processes, Desalination. 239 (2009) 10-21. doi:10.1016/j.desal.2008.0.

[54] K. Lutchmiah, E.R. Cornelissen, D.J.H. Harmsen, J.W. Post, K. Lampi, H. Ramaekers, L.C. Rietveld, K. Roest, Water recovery from sewage using forward osmosis, Water Sci. Technol. 64 (2011) 1443-1449. doi:10.2166/wst.2011.773.

[55] T. Hey, A. Zarebska, N. Bajraktari, J. Vogel, C. Hélix-Nielsen, J. la Cour Jansen, K. Jönsson, Influences of mechanical pretreatment on the non-biological treatment of municipal wastewater by forward osmosis, Environ. Technol. 38 (2016) 2295-2304. doi:10.1080/09593330.2016.1256440.

[56] J.C. Ortega-Bravo, G. Ruiz-Filippi, A. Donoso-Bravo, I.E. Reyes-Caniupán, D. Jeison, Forward osmosis: Evaluation thin-film-composite membrane for municipal sewage concentration, Chem. Eng. J. 306 (2016) 531-537. doi:10.1016/j.cej.2016.07.085.

[57] Y. Gao, Z. Fang, P. Liang, X. Huang, Direct concentration of municipal sewage by forward osmosis and membrane fouling behavior, Bioresour. Technol. 247 (2018) 730-735. doi:10.1016/j.biortech.2017.09.145.

[58] T.-S. Chung, S. Zhang, K.Y. Wang, J. Su, M.M. Ling, Forward osmosis processes: Yesterday, today and tomorrow, Desalination. 287 (2012) 78-81. doi:10.1016/j.desal.2010.12.019.

[59] B. Van Der Bruggen, P. Luis, Forward osmosis: understanding the hype, Rev. Chem. Eng. 31 (2014) 1-12. doi:10.1515/revce-2014-0033.

[60] A.J. Ansari, F.I. Hai, W.E. Price, J.E. Drewes, L.D. Nghiem, Forward osmosis as a platform for resource recovery from municipal wastewater - A critical assessment of the literature, J. Memb. Sci. 529 (2017) 195-206. doi:10.1016/j.memsci.2017.01.054.

[61] A.J. Ansari, F.I. Hai, W. Guo, H.H. Ngo, W.E. Price, L.D. Nghiem, Factors governing the preconcentration of wastewater using forward osmosis for subsequent resource recovery, Sci. Total Environ. 566-567 (2016) 559-566. doi:10.1016/j.scitotenv.2016.05.139.

[62] Y. Sun, J. Tian, Z. Zhao, W. Shi, D. Liu, F. Cui, Membrane fouling of forward osmosis (FO) membrane for municipal wastewater treatment: A comparison between direct FO and OMBR, Water Res. 104 (2016) 330-339. doi:10.1016/j.watres.2016.08.039.

[63] B. Mi, M. Elimelech, Organic fouling of forward osmosis membranes: Fouling reversibility and cleaning without chemical reagents, J. Memb. Sci. 348 (2010) 337-345. doi:10.1016/j.memsci.2009.11.021. 
[64] Z. Wang, J. Tang, C. Zhu, Y. Dong, Q. Wang, Z. Wu, Chemical cleaning protocols for thin film composite (TFC) polyamide forward osmosis membranes used for municipal wastewater treatment, J. Memb. Sci. 475 (2015) 184-192. doi:10.1016/j.memsci.2014.10.032.

[65] K. Lutchmiah, A.R.D. Verliefde, K. Roest, L.C. Rietveld, E.R. Cornelissen, Forward osmosis for application in wastewater treatment: A review, Water Res. 58 (2014) 179-197. doi:10.1016/j.watres.2014.03.045.

[66] R. Valladares Linares, Z. Li, M. Abu-Ghdaib, C.H. Wei, G. Amy, J.S. Vrouwenvelder, Water harvesting from municipal wastewater via osmotic gradient: An evaluation of process performance, J. Memb. Sci. 447 (2013) 50-56. doi:10.1016/j.memsci.2013.07.018.

[67] G. Qiu, Y.P. Ting, Direct phosphorus recovery from municipal wastewater via osmotic membrane bioreactor (OMBR) for wastewater treatment, Bioresour. Technol. 170 (2014) 221-229. doi:10.1016/j.biortech.2014.07.103.

[68] Y. Gu, L. Chen, J.W. Ng, C. Lee, V.W.C. Chang, C.Y. Tang, Development of anaerobic osmotic membrane bioreactor for low-strength wastewater treatment at mesophilic condition, J. Memb. Sci. 490 (2015) 197-208. doi:10.1016/j.memsci.2015.04.032.

[69] B.D. Coday, B.G.M. Yaffe, P. Xu, T.Y. Cath, Rejection of Trace Organic Compounds by Forward Osmosis Membranes: A Literature Review, Environ. Sci. Technol. 48 (2014) 3612-3624. doi:10.1021/es4038676.

[70] N.T. Hancock, P. Xu, D.M. Heil, C. Bellona, T.Y. Cath, Comprehensive bench- and pilot-scale investigation of trace organic compounds rejection by forward osmosis, Environ. Sci. Technol. 45 (2011) 8483-8490. doi:10.1021/es201654k.

[71] R. Valladares Linares, V. Yangali-Quintanilla, Z. Li, G. Amy, Rejection of micropollutants by clean and fouled forward osmosis membrane, Water Res. 45 (2011) 6737-6744. doi:10.1016/j.watres.2011.10.037.

[72] D.L. Shaffer, J.R. Werber, H. Jaramillo, S. Lin, M. Elimelech, Forward osmosis: Where are we now?, Desalination. 356 (2015) 271-284. doi:10.1016/j.desal.2014.10.031.

[73] C. Klaysom, T.Y. Cath, T. Depuydt, I.F.J. Vankelecom, Forward and pressure retarded osmosis: potential solutions for global challenges in energy and water supply, Chem. Soc. Rev. 42 (2013) 6959. doi:10.1039/c3cs60051c.

[74] J.R. McCutcheon, M. Elimelech, Influence of concentrative and dilutive internal concentration polarization on flux behavior in forward osmosis, J. Memb. Sci. 284 (2006) 237-247. doi:10.1016/j.memsci.2006.07.049.

[75] S. Zou, Y. Gu, D. Xiao, C.Y. Tang, The role of physical and chemical parameters on forward osmosis membrane fouling during algae separation, J. Memb. Sci. 366 (2011) 356-362. doi:10.1016/j.memsci.2010.10.030.

[76] S. Zhao, L. Zou, C.Y. Tang, D. Mulcahy, Recent developments in forward osmosis: Opportunities and challenges, J. Memb. Sci. 396 (2012) 1-21. doi:10.1016/j.memsci.2011.12.023.

[77] B. Corzo, T. de la Torre, C. Sans, E. Ferrero, J.J. Malfeito, Evaluation of draw solutions and commercially available forward osmosis membrane modules for wastewater reclamation at pilot scale, Chem. Eng. J. 326 (2017) 1-8. doi:10.1016/j.cej.2017.05.108.

[78] Q. Ge, M. Ling, T.S. Chung, Draw solutions for forward osmosis processes: Developments, 
challenges, and prospects for the future, J. Memb. Sci. 442 (2013) 225-237. doi:10.1016/j.memsci.2013.03.046.

[79] M. Evren, H. Ozgun, R. Kaan, I. Ozturk, K. Roest, J.B. Van Lier, A review on dynamic membrane filtration: Materials, applications and future perspectives, Bioresour. Technol. 122 (2012) 196-206.

[80] M. Saleem, L. Alibardi, M.C. Lavagnolo, R. Cossu, A. Spagni, Effect of filtration flux on the development and operation of a dynamic membrane for anaerobic wastewater treatment, J. Environ. Manage. 180 (2016) 459-465. doi:10.1016/j.jenvman.2016.05.054.

[81] M.E. Ersahin, H. Ozgun, Y. Tao, J.B. van Lier, Applicability of dynamic membrane technology in anaerobic membrane bioreactors, Water Res. $48 \quad$ (2014) 420-429. doi:10.1016/j.watres.2013.09.054.

[82] H. Gong, X. Wang, M. Zheng, Z. Jin, K. Wang, Direct sewage filtration for concentration of organic matters by dynamic membrane, Water Sci. Technol. 70 (2014) 1434-1440. doi:10.2166/wst.2014.379.

[83] B. Fan, X. Huang, Characteristics of a self-forming dynamic membrane coupled with a bioreactor for municipal wastewater treatment, Environ. Sci. Technol. 36 (2002) 5245-5251. doi:10.1021/es025789n.

[84] T. Hey, N. Bajraktari, Å. Davidsson, J. Vogel, H.T. Madsen, C. Hélix-Nielsen, J. la C. Jansen, K. Jönsson, Evaluation of direct membrane filtration and direct forward osmosis as concepts for compact and energy-positive municipal wastewater treatment, Environ. Technol. 39 (2017) 264-276. doi:10.1080/09593330.2017.1298677.

[85] M.R. S. Sousa, J. Lora-Garcia, M.-F. López-Pérez, Experimental study and modeling of forward osmosis process for activated sludge concentration by using residual brine from a stuffed olive factory as draw solution, J. Water Process Eng. 21 (2018) 143-153. doi:10.1016/j.jwpe.2017.12.008.

[86] W. Xue, K. Yamamoto, T. Tobino, Membrane fouling and long-term performance of seawaterdriven forward osmosis for enrichment of nutrients in treated municipal wastewater, J. Memb. Sci. 499 (2016) 555-562. doi:10.1016/j.memsci.2015.11.009. 



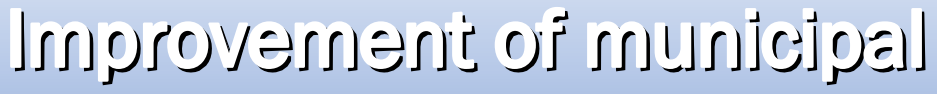

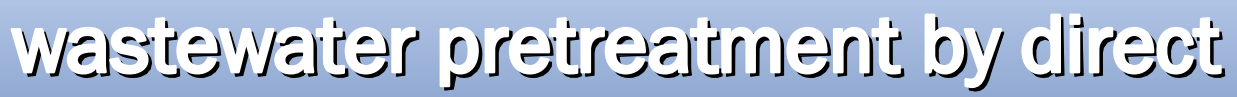 nennbrane nildratjon}
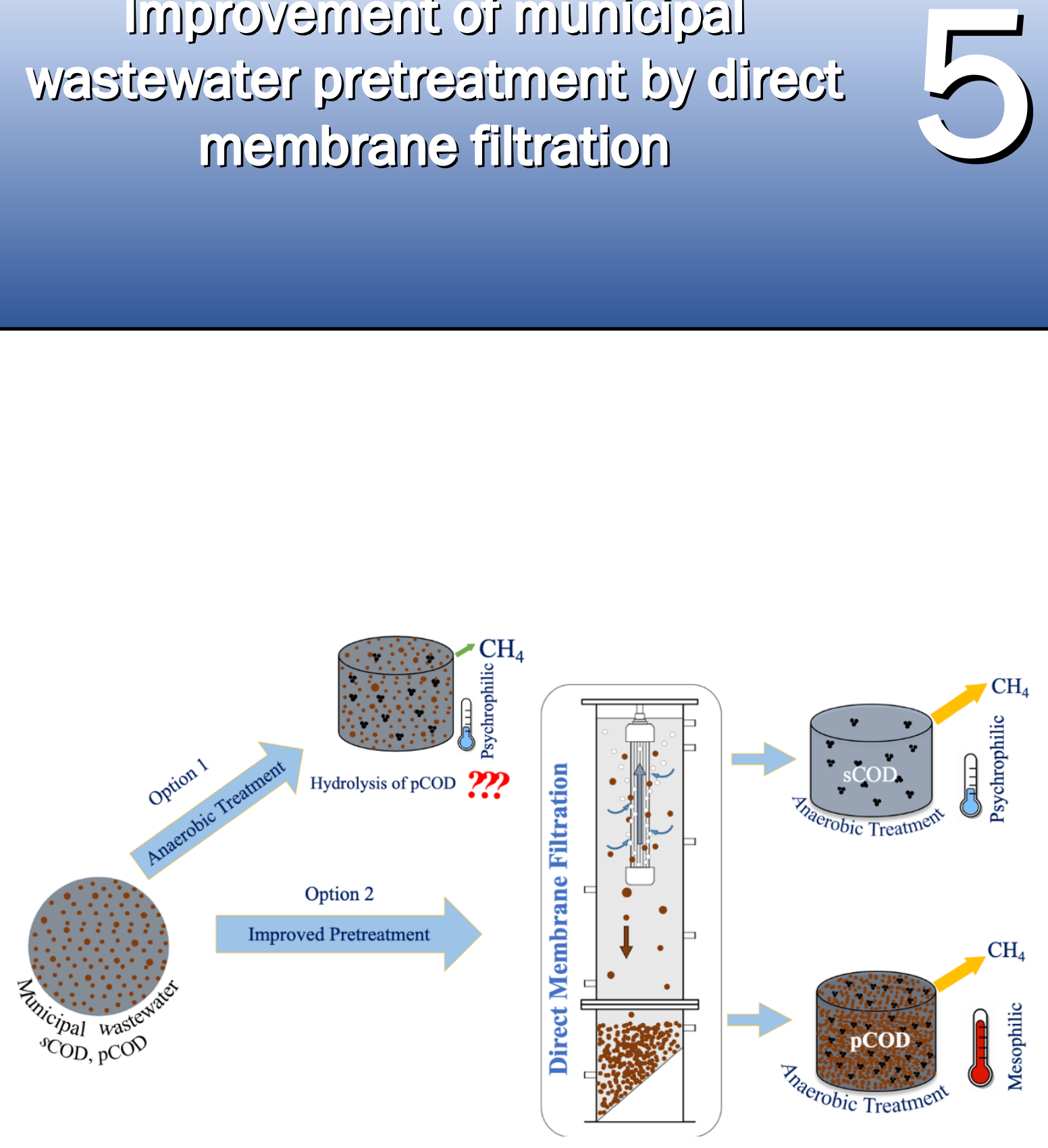



\title{
Improvement of municipal wastewater pretreatment by direct membrane filtration
}

\author{
Thiago A. Nascimentoa, Fanny R. Mejíaa, Fernando Fdz-Polancoa, Mar Peña Mirandaa* \\ a Department of Chemical Engineering and Environmental Technology. University of Valladolid. Spain. \\ *Corresponding author. Tel.: +34 983423166. E-mail address: pena@iq.uva.es
}

\section{Abstract}

The high content of particulate matter in municipal wastewater hinders the conventional anaerobic treatments at psychrophilic temperatures. The hydrolysis of the particulate chemical oxygen demand ( $p C O D$ ) could be the limiting step under these conditions. Therefore, new pretreatments or improved conventional pretreatments are needed in order to separate pCOD. In this work, direct membrane filtration of municipal wastewater, using an ultrafiltration membrane, was investigated. This intensive pretreatment, which aims to separate soluble chemical oxygen demand (SCOD) and to concentrate $\mathrm{pCOD}$, together with anaerobic treatments of both streams at psychrophilic and mesophilic conditions respectively, could be an alternative to the conventional activated sludge process. The obtained results show a removal yield of $24.9 \%$ of the total solids (TS) and $45 \%$ of total chemical oxygen demand (tCOD), obtaining a permeate free of suspended solids. This physical removal implies the accumulation of solids inside the membrane tank, reaching the values of 45.4 and $4.4 \mathrm{~g} / \mathrm{L}$ of TS in the sedimentation and filtration sections, respectively. The membrane operated with filtration, backwashing cycles and continuous gas sparging, with a permeate flux predominantly around $10 \mathrm{~L} /\left(\mathrm{m}^{2} \mathrm{~h}\right)$. The results show the viability of the technology to concentrate pCOD and so to improve energy recovery from municipal wastewater.

Keywords: Direct membrane filtration, wastewater solids concentration, anaerobic digestion, gas sparging, membrane cleaning. 


\section{Introduction}

New technologies of wastewater treatment are increasingly important. Various physical, chemical and biochemical methods of wastewater treatment are already well established or under investigation [1]. Nevertheless, the need for processes which ensure the adequacy of restrictive water quality criteria at a low cost and minimal environmental impact encourages the development of technologies that add efficiency, robustness and flexibility. In this line of thought, municipal wastewater membrane filtration and anaerobic treatments take a prominent position, and they are able to replace conventional technologies that are not energy efficient.

Municipal wastewaters are characterized by having low strength, and high content of particulate organic matter. In most cases, the treatment is accomplished by conventional activated sludge (CAS) processes. In these cases, the treatment not only does not take advantage of the energy content from the wastewater, since approximately $45 \%$ of the total biodegradable chemical oxygen demand is oxidized to carbon dioxide and water [2], but it also requires a high power consumption for the aeration basins, and implies elevated handling and disposal costs for the excess sludge [3]. The specific power consumption of the air supply ranges from 0.3 to 1.89 $\mathrm{kWh} / \mathrm{m}^{3}[2,4]$ and it represents at least $50 \%$ of the wastewater treatment plant (WWTP) demand. Clearly, this process needs serious attention, emphasizing on the positive energy balance and on sludge reduction [5].

On the other hand, the high content of particulate matter in the municipal wastewater, around $65 \%$ of total chemical oxygen demand (tCOD) $[6,7]$, complicates the conventional anaerobic treatments at psychrophilic temperatures. The hydrolysis of the particulate chemical oxygen demand ( $p C O D$ ) could be the limiting step in the anaerobic treatments at psychrophilic conditions $[8,9]$. Hence, it is necessary to study pretreatments that significantly improve the separation of the particulate and the 
soluble organic matter from municipal wastewater, enabling the anaerobic treatment of both fractions individually. Generally, the existing pretreatments have a low particulate material removal efficiency, or they require a very high energy consumption. Therefore, the complete separation of $\mathrm{pCOD}$, from soluble chemical oxygen demand (SCOD), through direct membrane filtration (DMF) in combination with the anaerobic treatment of each of the fraction at different temperatures could be a feasible alternative technology to recover most of the organic content from the municipal wastewater in methane-rich biogas. The DMF would produce two streams: a stream containing high concentration of $\mathrm{pCOD}$ and a major stream completely free of it that would contain only readily biodegradable SCOD. The SCOD fraction would be treated at psychrophilic conditions in an Upflow Anaerobic Sludge Blanket (UASB) reactor, whereas the concentrated particulate fraction would be digested under mesophilic conditions. The UASB reactors can be used efficiently with low and medium organic loads at low ambient temperatures, alone or coupled with other systems, as reported by several authors [10-14].

Membrane filtration has become a widespread used technology accepted for separation operations in recent decades. Pore size flexibility, membrane module shape and a variety of effluents which can be worked with allowed the membrane technology to be elected as both a domestic and an industrial wastewater treatment method [15-17].

The main drawback of DMF is the membrane fouling; nevertheless, the extensive documented research with membrane bioreactors [18] points to some main strategies such as applying appropriate pretreatments to the feed water, or employing appropriate physical or chemical cleaning protocols to overcome this drawback. 
The membrane lifetime and, hence, the process sustainability can be increased by some practices such as good screening of larger solids before the membranes to protect them from physical damage [19]. New materials and membrane configuration can also contribute to overcome this problem.

There are very few studies on the DMF process; however, their preliminary results are promising [20-24]. In contrast to the expectation that membrane fouling cannot be controlled in DMF of domestic waste- water, Lateef et al. [20]reported that a continuous and stable filtration process is possible with relatively high membrane fluxes by applying chemically enhanced backwash. Further, Jin et al. [21] reached a slower decrease in the permeability of the microfiltration membrane, and a high concentration of tCOD with a combination of coagulation and intermittent aeration. Nevertheless, in spite of the efforts to achieve a long-term DMF process, in most of the cases the authors have reported short periods of operation or the DMF process has been carried out together with other physicochemical processes [22-25]as an attempt to facilitate the membrane operation. Therefore, more studies should be conducted in order to determine the applicability of this promising technology.

The aim of this work is to study the feasibility of DMF of the effluent from the primary clarifier $(\mathrm{CL})$ of municipal wastewater, operating in continuous mode and controlling the membrane fouling by filtration and backwashing cycles as well as continuous gas sparging in order to obtain a high concentration of particulate matter.

\section{Materials and Methods}

\subsection{Municipal wastewater}

Raw municipal wastewater was continuously obtained from a collector of the sanitary system from the city of Valladolid (Spain). The wastewater proceeded from a residential area and it presents domestic wastewater characteristics (i.e. without 
industrial compounds). Table 1 shows the main characteristics of wastewater fed to the pilot plant.

Table 1 - Wastewater feed (S.p.2) and permeate (S.p.5) characteristics.

\begin{tabular}{cccccc}
\hline & \multicolumn{2}{c}{ First run } & & \multicolumn{2}{c}{ Second run } \\
\cline { 2 - 3 } \cline { 5 - 6 } \cline { 5 - 6 } & Feed & Permeate & & Feed & Permeate \\
\hline $\operatorname{tCOD}(\mathrm{mg} / \mathrm{L})$ & $715.7 \pm 142.9$ & $393.5 \pm 57.3$ & & $1038.1 \pm 231.1$ & $553.6 \pm 133.7$ \\
$\operatorname{SCOD}(\mathrm{mg} / \mathrm{L})$ & $402.6 \pm 107.5$ & $393.5 \pm 57.3$ & & $662.3 \pm 117.9$ & $553.6 \pm 133.7$ \\
$\operatorname{TS}(\mathrm{mg} / \mathrm{L})$ & $831.1 \pm 81.9$ & $661.3 \pm 60.8$ & & $806.3 \pm 136.1$ & $582.3 \pm 85.2$ \\
$\operatorname{VS}(\mathrm{mg} / \mathrm{L})$ & $422.3 \pm 75.5$ & $275.0 \pm 44.4$ & & $429.3 \pm 65.1$ & $253.8 \pm 50.0$ \\
$\operatorname{TSS}(\mathrm{mg} / \mathrm{L})$ & $120.8 \pm 34.8$ & 0 & & $152.6 \pm 31.7$ & 0 \\
$\operatorname{VSS}(\mathrm{mg} / \mathrm{L})$ & $107.5 \pm 32.8$ & 0 & & $135.5 \pm 29.2$ & 0 \\
\hline
\end{tabular}

\subsection{Pilot plant configuration}

A schematic representation of the pilot plant used in this study is shown in Figure 1. The municipal wastewater was driven by a submerged centrifugal pump (P01) from the sewage system near the laboratory, passed through a rotary screen (RS) (1 $\mathrm{mm}$ mesh) and then fed to the $\mathrm{CL}$. The effluent from the $\mathrm{CL}$ was pumped (P-03) into the membrane tank (MT), with a total volume of $136 \mathrm{~L}$ (height $180 \mathrm{~cm}$ and diameter $31 \mathrm{~cm})$. The membrane module was placed on the upper part, hanging from the top of the tank. A hollow-fiber ultrafiltration membrane was used (ZW-10 Zenon, GE) with a mean pore size of $0.04 \mu \mathrm{m}$ and a filtration area of $0.93 \mathrm{~m}^{2}$. The membrane module had a total length of $68.5 \mathrm{~cm}$, and inside the tank it was surrounded by a polyvinyl chloride cylinder of $14 \mathrm{~cm}$ internal diameter. The MT was not full of wastewater; there was a small headspace in its upper part connected to a water seal. In order to control membrane fouling, continuous gas sparging (coarse bubble) from the headspace to the bottom of the membrane fibers was used (compressor $\mathrm{C}$ ), working with different superficial gas velocities or specific gas demand per permeate volume (SGDp defined as $\mathrm{m}^{3}$ gas $/ \mathrm{m}^{3}$ permeate). In addition to the continuous gas sparging, a permeate backwashing was applied to avoid membrane fouling and to 
maintain a steady transmembrane pressure (TMP). A Watson Marlow peristaltic pump (model 520U) (P-04) was used for filtration and backwashing. The filtration cycle was composed of filtration ( 7.5 minutes), relaxation ( 5 seconds pump pause), backwash (15 or 30 seconds) and further relaxation ( 5 seconds pump pause). The bottom of the MT was equipped with a baffle plate to separate solid sedimentation coming from the influent wastewater and the retained solids from the filtration section. The data obtained by the temperature transmitter (TT) and pressure transmitters (PTs) were stored online using PicoLog Data Acquisition Technology ${ }^{\circledR}$ software. The pilot plant had different sampling points at the bottom of the CL (S.p.1), at the feed entrance to the MT (S.p.2), at the filtration section (S.p.3), at the sedimentation section inside the MT (S.p.4) and at the permeate from the membrane (S.p.5).

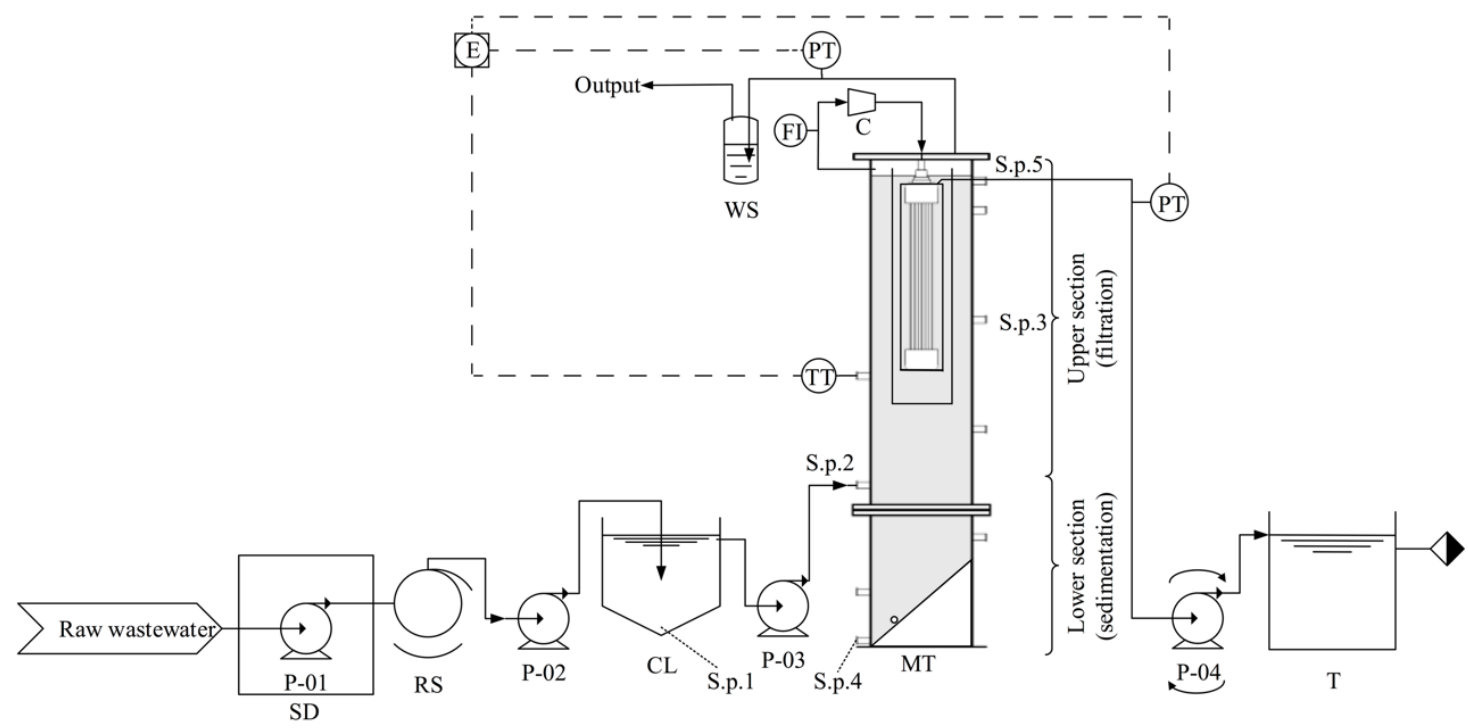

Figure 1 - Schematic representation of the pilot plant (P-01: centrifugal pump; SD: sewer drain; RS: rotary screen; P-02: peristaltic pump; CL: clarifier; P-03: peristaltic pump; MT: membrane tank; P-04: peristaltic pump; t: storage tank; c: compressor; WS: water seal; e: com- puter; Fl: gas recirculation flow indicator; PT: pressure transmitter; TT: temperature transmitter). 


\subsection{Chemical assays and sampling}

Samples were taken to monitor the process by means of routine analysis from the sampling points (S.p.) 2, 3, 4 and 5, according to Figure 1 . The analysis of tCOD, sCOD, total solids (TS), VS, total suspended solids (TSS) and volatile suspended solids (VSS) was performed in order to evaluate the behavior of solid matter accumulation inside the MT and the filtration performance. The procedures to collect and to analyze the samples followed the Standard Methods for the Examination of Water and Wastewater [26]. During the first running period, the samples for the determination of tCOD and SCOD were taken once every two days, while the samples to determine TS and VS were taken once every seven days and the samples to determine TSS and VSS were taken once every five days. During the second run, these samples were taken every five days to analyze all parameters. The samples collected from S.p.1 were only used for anaerobic biodegradability assays.

\subsection{Biochemical methane potential assay}

Biochemical methane potential (BMP) assays at mesophilic $\left(35.1 \pm 0.3^{\circ} \mathrm{C}\right)$ conditions were performed according to the method described by Angelidaki et al. [27] in order to assess the biodegradability of the accumulated solids from the CL (S.p.1), from the upper section of the MT (S.p.3) and from the lower section of the MT (S.p.4). The tests were performed in triplicate; the anaerobic inoculum employed was obtained from a pilot sludge digester and pre-incubated for two days $\left(35.1 \pm 0.3^{\circ} \mathrm{C}\right.$ ) to minimize its residual biodegradable organic matter content. Further, a blank test without substrate was included. Serum bottles of $160 \mathrm{~mL}$ volume were used in the BMP tests, with a reaction volume of $80 \mathrm{~mL}$ in order to allow enough headspace for biogas accumulation. The substrate/inoculum ratio selected was $0.4 \mathrm{gVS}_{\text {subs }} / \mathrm{gVS}_{\text {inoc* }}$. The $\mathrm{pH}$ of the substrate/inoculum mixture was measured in order to ensure optimum 
biological activity. The bottles were sealed, using rubber septa and aluminum crimp caps, and then flushed with helium gas. All the above experiments were subjected to continuous agitation in an orbital shaker. Biogas production was estimated by measuring the pressure in the headspace of the bottles and the biogas composition. The specific methane yield (SMY) was calculated by dividing the net methane production associated with the substrate by the quantity of volatile solids (VS) from the substrate at the beginning of the test, that is, $\mathrm{mLCH}_{4} /\left(\mathrm{gVS}_{\mathrm{fed}}\right)$. A BMP test was also carried out with the permeate under psychrophilic conditions $\left(16^{\circ} \mathrm{C}\right)$, and using inoculum adapted to the low temperature.

Biogas composition was analyzed using a gas chromatograph (Varian CP-3800, Palo Alto, CA, USA) coupled with a thermal conductivity detector and equipped with a CP-Molsieve 5A $(15 \mathrm{~m} \times 0.53 \mathrm{~mm} \times 15 \mu \mathrm{m})$ and a CP-Pora BOND Q $(25 \mathrm{~m} \times 0.53$ $\mathrm{mm} \times 15 \mu \mathrm{m})$ column.

\subsection{Pilot plant operation mode}

The experimentation was divided into two periods: 0-54 days and 55-104 days. During the former period, the continuous filtration process was started at a low permeate flux of $2.4 \mathrm{~L} /\left(\mathrm{m}^{2} \mathrm{~h}\right)$ and it was gradually increased in order to assess the behavior of the TMP, and the accumulation of solids within the MT. During the latter period, the filtration was started with a permeate flux of $10.1 \mathrm{~L} /\left(\mathrm{m}^{2} \mathrm{~h}\right)$, and with a superficial gas velocity higher than that in the former period. Further, the SGDp was also increased in order to provide for continuous mem- brane filtration. The pilot plant was continuously fed until the TMP reached values of around 700 mbar or until the permeate flux decreased significantly. After both experiments, the membrane was chemically cleaned. During each period, no solid purges were made from the MT 
except for the samples collected at the sampling points S.p.3 and 4. Table 2 summarizes the direct filtration operating conditions.

Table 2 - Pilot plant operating conditions

\begin{tabular}{ccccc}
\hline $\begin{array}{c}\text { Period } \\
(\text { Days })\end{array}$ & $\begin{array}{c}\text { Filtration Flux } \\
\left(\mathrm{L} /\left(\mathrm{m}^{2} \mathrm{~h}\right)\right)\end{array}$ & $\begin{array}{c}\text { Total time of } \\
\text { filtration cycle } \\
(\mathrm{min})\end{array}$ & $\begin{array}{c}\text { Superficial } \\
\text { Gas Velocity } \\
(\mathrm{m} / \mathrm{h})\end{array}$ & $\begin{array}{c}\text { SGDpa }^{2} \\
\left(\mathrm{~m}^{3} \text { gas } / \mathrm{m}^{3}\right. \\
\text { permeate })\end{array}$ \\
\hline $1-14$ & 2.4 & 7.92 & 8 & 55.2 \\
$14-29$ & 4.7 & 7.92 & 16 & 56.3 \\
$29-41$ & 7.1 & 7.92 & 23 & 53.6 \\
$41-54$ & 9.4 & 7.92 & 39 & 68.7 \\
$54-80$ & 10.1 & 7.92 & 55 & 90.1 \\
$80-95$ & 13.4 & 8.17 & 55 & 67.9 \\
$95-104$ & 10.1 & 8.17 & 70 & 114.7 \\
\hline
\end{tabular}

a Specific gas demand per permeate volume.

\subsection{Membrane cleaning}

The membrane was cleaned outside the MT, first, physically and, second, by different chemical methods. The physical cleanings were performed with a jet of tap water, which ensures the full removal of the visible encrusted solids around the membrane fibers. After each physical cleaning, the membrane module was submitted to different chemical reagents and conditions depending on each case. After the first run, the membrane module was cleaned with sodium hypochlorite $500 \mathrm{ppm}$ at $18^{\circ} \mathrm{C}$ during a period of 4 hours (renewing the solution every two hours). After the second run, the chemical cleaning consisted of washing the membrane module with sodium hypochlorite at $1000 \mathrm{ppm}$ and $35^{\circ} \mathrm{C}$ during a period of three hours (renewing the solution each hour). Then it was cleaned with ethylenediamine tetraacetic acid (EDTA) $0.8 \%(\mathrm{w} / \mathrm{w})\left(2\right.$ hours at $\left.40^{\circ} \mathrm{C}\right)$ and finally it was cleaned with citric acid $1.0 \%(\mathrm{w} / \mathrm{w})(1$ hour at $40^{\circ} \mathrm{C}$ ). After each physical and chemical cleaning, the membrane was characterization with tap water at $16^{\circ} \mathrm{C} \pm 1$. 


\section{Results and discussion}

\subsection{Removal efficiency of COD and solids}

The characteristics of the pre-clarified municipal wastewater, fed to the MT, (Sp.2) and the permeate (Sp.5) for the first and second runs are indicated in Table 1. During the first run, the average values of tCOD for the MT influent and permeate were $715.7 \pm 142.9$ and $393.5 \pm 57.3 \mathrm{mg} \mathrm{O} / \mathrm{L}$, respectively. However, for the second run these values correspond to $1038.1 \pm 231.1$ and $553.6 \pm 133.7 \mathrm{mgO}_{2} / \mathrm{L}$, respectively. The data imply average removal rates of $45 \%$ and $47 \%$ of tCOD, which is retained inside the MT for the first and second runs, respectively. These results are very similar to those obtained by Lateef et al. [20] who studied the organic matter recovery from municipal wastewater in DMF. They approximately reached $45 \%$ of COD recovery inside the $\mathrm{MT}$, by disregarding the particulate matter deposited on the inside walls of both tanks.

In terms of TS and VS, the average removal rates were $20 \%$ and $35 \%$, respectively, for the first run, and $28 \%$ and $41 \%$, respectively, for the second run. The VS in the permeate represents approximately $42 \%$ and $44 \%$ of the TS content (Table 1). As it was expected, these results indicate the need for further treatment in order to recover most of the soluble organic content from the permeate in methane-rich biogas. Since the TSS and VSS were completely removed in the filtration process, it would be possible to carry out the anaerobic treatment of the permeate stream under psychrophilic conditions, by considering that the hydrolysis of the pCOD would not be the limiting step. 


\subsection{Accumulation of solids inside the MT}

The tCOD/solids removed from the permeate stream by DMF were accumulated inside the MT. Figure 2 shows the accumulation of TS/VS and TSS/VSS inside the MT during 104 days of DMF operation.

In the first run, the tCOD and TS reached in the filtration section were $5.4 \mathrm{gO}_{2} / \mathrm{L}$ and $2.4 \mathrm{~g} / \mathrm{L}$, respectively, whereas in the second run the maximum values reached in the filtration section corresponded to $10.2 \mathrm{gO}_{2} / \mathrm{L}$ and $4.4 \mathrm{~g} / \mathrm{L}$ for the tCOD and TS, respectively. Higher values for the second run were expected since the total amount of municipal wastewater filtered in this run was higher than the filtered wastewater in the first run; therefore, more matter was accumulated inside the MT during the 49 days of the second run, even though the first run lasted 54 days. The concentration of the achieved COD in the filtration section has a similar order of magnitude to the values reported by other authors such as Lateef et al. [20], Gong et al. [28] and Jin et al. [29] who obtained COD concentrations of around 5.0, 7.5 and $15.0 \mathrm{gO}_{2} / \mathrm{L}$, respectively, working with complete mixed liquor. 
(a)
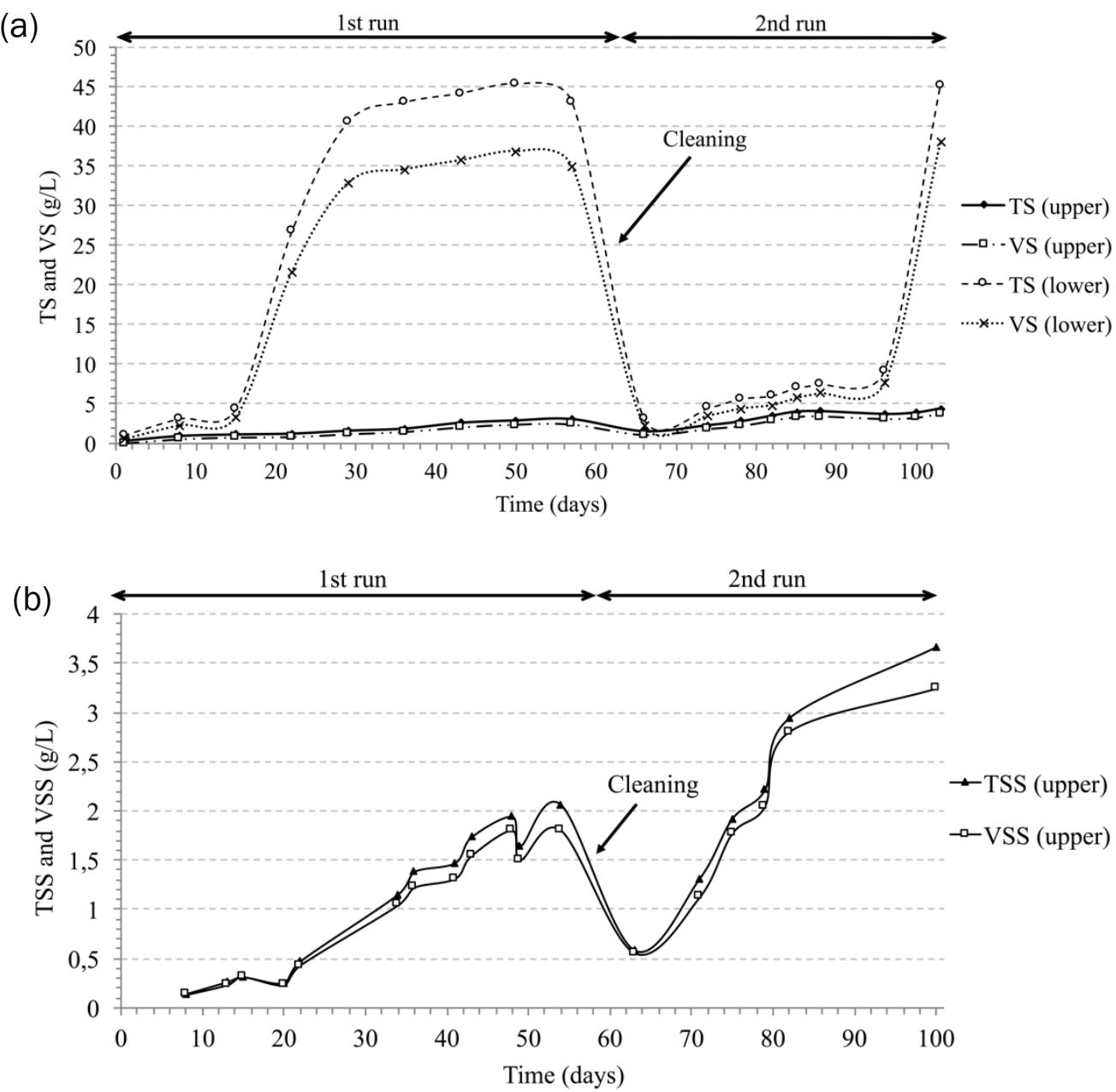

Figure 2 - (a) TSS and VSS concentration in the upper section of the MT. (b) TS and VS concentration in the upper and lower sections of the MT.

In addition, in this work, the TSS and VSS concentration profiles in the filtration section present different final values and accumulation rates in both experiments (Figure 2(a)). In the first period, the final TSS concentration was $2.1 \mathrm{~g} / \mathrm{L}$ operating with a superficial gas velocity around $39 \mathrm{~m} / \mathrm{h}$. Under these conditions, the average accumulation rate of TSS was $0.05 \mathrm{~g} /(\mathrm{Ld})$. However, in the second period, the final TSS concentration was $3.7 \mathrm{~g} / \mathrm{L}$ with a superficial gas velocity of around $70 \mathrm{~m} / \mathrm{h}$. As a consequence, we obtained a higher average accumulation rate of TSS that reaches a value of $0.12 \mathrm{~g} /(\mathrm{Ld})$. Accordingly, the higher gas velocity increased the suspended solid accumulation in the filtration section and, therefore, decreased the accumulation rate of solids in the sedimentation section. 
On the other hand, in the sedimentation section, the accomplished TS were significantly higher than those obtained in the upper section. The TS concentration reached a value around of $45 \mathrm{~g} / \mathrm{L}$ for both periods of operation (Figure 2(b)); nevertheless, there is a clear difference in the behavior patterns. While the concentration of TS took around 15 days to start increasing in the first run, in the second run this accumulation increased significantly after 42 days of operation. This can be explained by the higher SGDp applied during the second run, which affected the sedimentation conditions of the accumulated particles, thus facilitating the increase in suspended particles in the filtration section. During the first run, the low turbulence due to the gas velocities was not high enough to hinder the settling of particles. The operating conditions, namely, the superficial gas velocity in the filtration section, have directly affected the behavior of solids accumulation in the MT. The lower section was not subjected to the high agitation caused by the gas sparging and, therefore, the solids were effectively concentrated.

The MT design is a fundamental issue for the DMF of wastewater. The existence of two zones, under different turbulence conditions, allowed the fouling control of the membrane by means of gas sparging, without compromising either the membrane performance or the sedimentation of the accumulated solids.

\subsection{Membrane behavior}

Figure 3 shows the behavior of the membrane throughout the direct filtration process. 


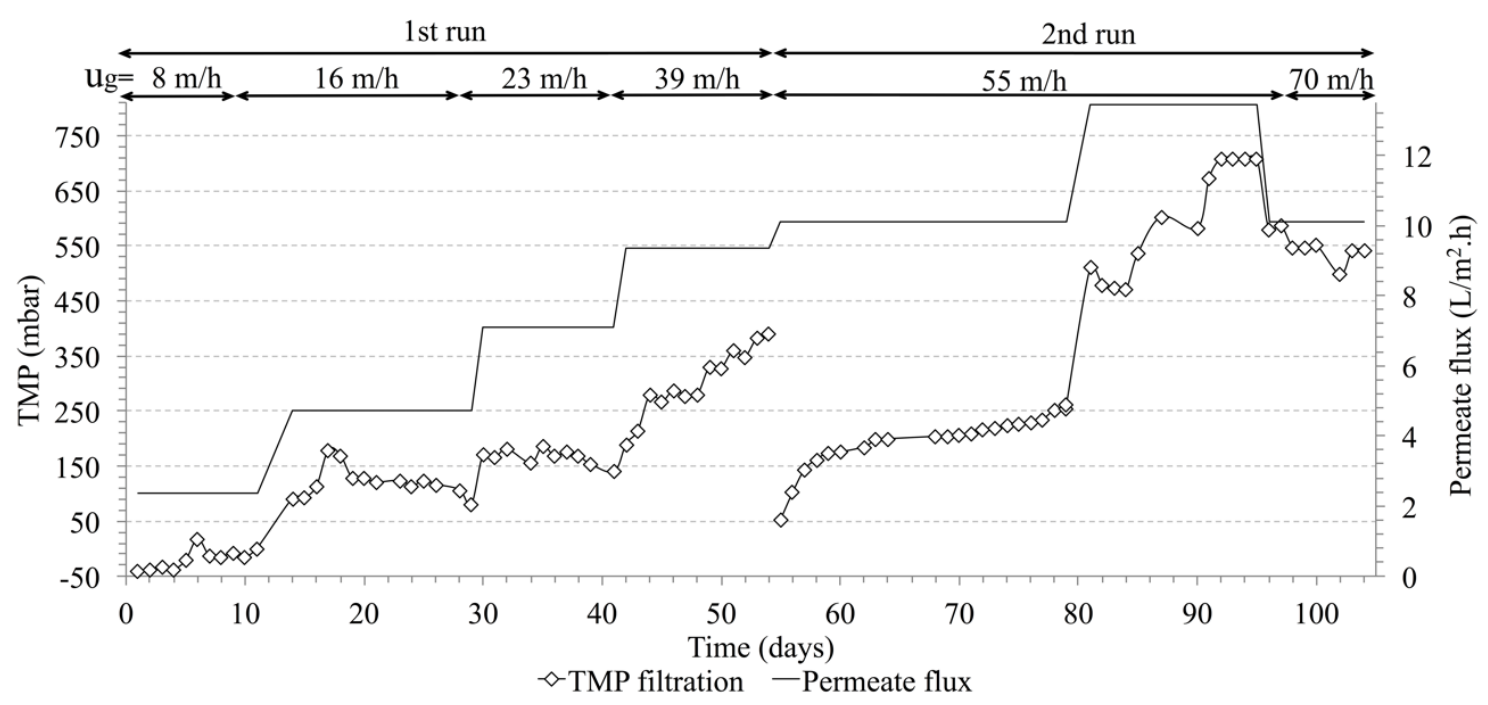

Figure 3 - Behavior of TMP, permeate fluxes and superficial gas velocity during the DMF operation.

During the first experiment, the permeate flux was gradually increased approximately every two weeks. In order to control the membrane fouling, the superficial gas velocity and, therefore, the SGDp were increased simultaneously with the permeate flux. As shown in Figure 3, a sudden increase in the TMP occurred as a consequence of the permeate flux increase. Nevertheless, the fouling rate, defined as the daily increase in the TMP after the sudden increase, was different depending on the operating conditions such as specific gas demand, solids concentration and membrane fouling. For example, for permeate fluxes of 4.7 and $7.1 \mathrm{~L} /\left(\mathrm{m}^{2} \mathrm{~h}\right)$, which operate at SGDp $=56.3 \mathrm{~m}^{3} / \mathrm{m}^{3}$ and SGDp $=53.6 \mathrm{~m}^{3} / \mathrm{m}^{3}$, respectively, the fouling rate during the experimentation time of each flux was almost negligible, with a value around $0.2 \mathrm{mbar} / \mathrm{d}$. However, by the end of the first run, when the filtration flux was increased up to $9.4 \mathrm{~L} /\left(\mathrm{m}^{2} \mathrm{~h}\right)$, and coinciding with the higher concentration of solids in the filtration section, the fouling rate increased markedly, to values of around 12.9 $\mathrm{mbar} / \mathrm{d}$ in spite of the fact that the SGDp was increased to $69 \mathrm{~m}^{3} / \mathrm{m}^{3}$. In the second run, after the membrane cleaning and when we were operating at a superficial gas velocity of $55 \mathrm{~m} / \mathrm{h}\left(\mathrm{SGDp} 90.1 \mathrm{~m}^{3} / \mathrm{m}^{3}\right)$ and a filtration flux of $10 \mathrm{~L} /\left(\mathrm{m}^{2} \mathrm{~h}\right)$ around a 
period of approximately 16 days, the fouling rate reached the value of $4.1 \mathrm{mbar} / \mathrm{d}$. On the other hand, when we maintained the superficial gas velocity constant at 55 $\mathrm{m} / \mathrm{h}$ and increased the permeate flux up to $13 \mathrm{~L} /\left(\mathrm{m}^{2} \mathrm{~h}\right)$, which caused a decrease in the SGDp to $67.8 \mathrm{~m}^{3} / \mathrm{m}^{3}$, a fouling rate around $20.6 \mathrm{mbar} / \mathrm{d}$ originated and the TMP increased up to 700 mbar. Further, in order to maintain the direct filtration for a longer period of time, we increased the backwash time from 15 to 30 seconds, we decreased the filtration flux to $10 \mathrm{~L} /\left(\mathrm{m}^{2} \mathrm{~h}\right)$ and we increased the superficial gas velocity to $70 \mathrm{~m} / \mathrm{h}$, which implied a SGDp of $114.7 \mathrm{~m}^{3} / \mathrm{m}^{3}$. This strategy allowed the continuous filtration for nine days more. During this time, the fouling rate was maintained almost negligible as a consequence of the permeate flux decrease. Nevertheless, this strategy implied a significant increase in the gas sparging for a low increase in the operation time and at a high TMP. Judd and Judd [30] showed values of SGDp approximately between 8 and $30 \mathrm{~m}^{3} / \mathrm{m}^{3}$ for membrane bioreactor (MBR) pilot plants operating with fluxes between 10 and $37 \mathrm{~L} /\left(\mathrm{m}^{2} \mathrm{~h}\right)$, when they were using a hollow-fiber GE Zenon module on submerged configurations. The higher SGDp needed in this work could be due to the different specific resistance of the solids from the raw municipal wastewater com- pared to the specific resistance of the activated sludge from the MBR. In this regard, other strategies should be studied in order to reduce the SGDp, because it represents a notable energy consumption in the energy balance of the DMF technology.

The operation at a permeate flux lower than $9 \mathrm{~L} /\left(\mathrm{m}^{2} \mathrm{~h}\right)$ and a SGDp of around $56 \mathrm{~m}^{3} / \mathrm{m}^{3}$ has enabled the DMF of wastewater under a moderate fouling rate for a period of 40 days and low TMP values. Nevertheless, other studies have reported only a few hours of the DMF operation due to the increase in the resistance [20,21,28,29]. Gong et al. [28] detailed an increase in the membrane resistance of around $1.5 \times 10^{13} \mathrm{~m}^{-1}$ after $120 \mathrm{~h}$ of operation. However, they were working with 
coagulation/adsorption and a permeate flux of $5 \mathrm{~L} /\left(\mathrm{m}^{2} \mathrm{~h}\right)$. In our study, the total filtration resistance (Table 3 ) increased up to $14.6 \times 10^{12} \mathrm{~m}^{-1}$ at the end of the first experiment after 54 days of operation. During the second run, the filtration resistance increased up to $19.6 \times 10^{12} \mathrm{~m}^{-1}$, which corresponds to the higher permeate flux applied $\left(13.4 \mathrm{~L} /\left(\mathrm{m}^{2} \mathrm{~h}\right)\right)$ and the lower SGDp $\left(67.9 \mathrm{~m}^{3} / \mathrm{m}^{3}\right)$ of the experiment. On the other hand, Ma et al. [31] were able to operate on a long-term basis by combining mechanisms of fouling control, which enabled 300 days of operation by employing a hybrid system composed of coagulation/flocculation and dynamic membrane separation at a flux of $60 \mathrm{~L} /\left(\mathrm{m}^{2} \mathrm{~h}\right)$.

From the results obtained in this work, it was observed that both start-up strategies of the filtration process (gradual increase of the permeate flux or starting with a higher permeate flux) were valid. The start-up with a permeate flux of $10 \mathrm{~L} /\left(\mathrm{m}^{2}\right.$ h) and SGDp of $90.1 \mathrm{~m}^{3} / \mathrm{m}^{3}$ did not hinder the system operation. Furthermore, it was possible to work under stable conditions which reached a fouling rate around 4.1 mbar/d during a period of 25 days of operation.

Table 3 - Fouling rate and filtration resistance during experiments

\begin{tabular}{cccc}
\hline $\begin{array}{c}\text { Permeate flux } \\
\left(\mathrm{L} /\left(\mathrm{m}^{2} . \mathrm{h}\right)\right)\end{array}$ & $\begin{array}{c}\text { Fouling rate } \\
\mathrm{dTMP} / \mathrm{dt}(\mathrm{mbar} / \mathrm{d})\end{array}$ & $\begin{array}{c}\text { Filtration resistance } \\
\left(10^{12} \mathrm{~m}^{-1}\right)\end{array}$ & $\begin{array}{c}\text { Superficial gas } \\
\text { velocity }(\mathrm{m} / \mathrm{h})\end{array}$ \\
\hline $1^{\text {st } \text { run }}$ & 3.9 & 1.6 & 8 \\
2.4 & $\cong 0$ & 9.4 & 16 \\
4.7 & 0.2 & 8.7 & 23 \\
7.1 & 12.9 & 14.6 & 39 \\
9.4 & & & 55 \\
$2^{\text {nd } r u n}$ & 4.1 & 8.8 & 55 \\
10.1 & 20.6 & 19.6 & 70 \\
13.4 & $\cong 0$ & 18.3 & \\
10.1 & & & \\
\hline
\end{tabular}




\subsection{Biodegradability of the accumulated solids and permeate stream}

At the end of the first experiment, a BMP test was carried out under mesophilic conditions using the accumulated solids. Figure 4 shows the SMY of the solids from the MT and from the CL. The mean values of SMY obtained were $360.8 \pm 6.5$ $\mathrm{mLCH}_{4} /\left(\mathrm{gVS}_{\text {fed }}\right)$ for the $\mathrm{CL}, 294.9 \pm 12.2 \mathrm{mLCH}_{4} /(\mathrm{gVS}$ fed $)$ for the filtration section and $323.0 \pm 8.0 \mathrm{mLCH}_{4} /\left(\mathrm{gVS}_{\mathrm{fed}}\right)$ for the sedimentation section, after 20, 23 and 15 days of mesophilic digestion, respectively. The results are similar to the SMY related by several authors who studied the biodegradability of primary and secondary sludge from different WWTPs [32-34]. For example, Astals et al. [32] showed a SMY in the range of $324.5-379.9 \mathrm{mLCH}_{4} /\left(\mathrm{gVS}_{\mathrm{fed}}\right)$ for BMP assays of different mixtures of primary sludge and waste-activated sludge from six different WWTPs. Eskicioglu et al. [33] also reported a production of $308.4 \mathrm{mLCH}_{4} /(\mathrm{gVS}$ fed $)$ for waste-activated sludge without pretreatments. Nevertheless, the previous studies found a higher SMY than Park et al. [34]; namely, they reported values of SMY of 227.1 and 192.2 $\mathrm{mLCH}_{4} /\left(\mathrm{gVS}_{\mathrm{fed}}\right)$ for primary sludge and waste-activated sludge, respectively.

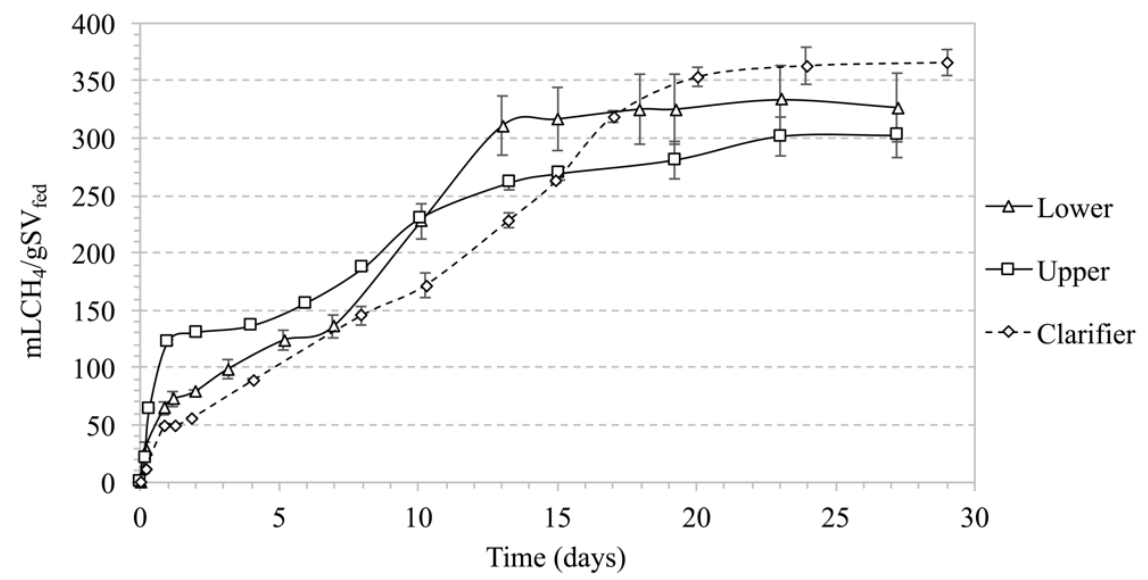

Figure 4 - Mesophilic BMP tests of the accumulated matter taken from different sections of the pilot plant. 
In this work, the behavior of the production curves of the accumulated methane was different for each of the sections, in spite of the similarity of the methane production yields obtained for the accumulated solids, as shown in Figure 4.

The accumulated material in the CL and at the filtration section, samples S.p.1 and S.p.3, revealed profiles composed of materials with different rates of biodegradation. Both aforementioned samples presented two fractions: a rapidly biodegradable one, and another fraction with a lower rate of biodegradation. However, the proportion of those fractions was completely different. In the CL, the rapidly biodegradable accumulated material fraction was $14 \%$ at a rate of biodegradation of $56 \mathrm{mLCH}_{4} /(\mathrm{gVS}$ fed $\mathrm{d})$, while in the filtration section, the rapidly biodegradable fraction was $42 \%$ at a significantly higher rate of biodegradation of $120 \mathrm{mLCH}_{4} /\left(\mathrm{gVS}_{\text {fed }} \mathrm{d}\right)$. Nevertheless, the fraction of the accumulated solid with low biodegradability showed a biodegradation rate between 14 and $16 \mathrm{mLCH}_{4} /\left(\mathrm{gVS}_{\text {fed }} \mathrm{d}\right)$ for both samples. On the other hand, the accumulated material in the sedimentation section of the MT (S.p.4) showed a methane production profile different from the previous samples. It showed a low fraction (around 14\%) which was rapidly biodegradable at a rate of $68 \mathrm{mLCH}_{4} /\left(\mathrm{gVS}_{\text {fed }} \mathrm{d}\right)$, and two other fractions with a biodegradation rate of $13 \mathrm{mLCH}_{4} /\left(g V S_{\text {fed }} \mathrm{d}\right)$ and $28 \mathrm{mLCH}_{4} /\left(g V S_{\text {fed }} \mathrm{d}\right)$, respectively. The differences observed between the three aforementioned samples may be due to the different particle sizes and composition of the accumulated material in each section. The higher biodegradation rate $\left(120 \mathrm{mLCH}_{4} /\left(\mathrm{gVS}_{\text {fed }} \mathrm{d}\right)\right)$ was obtained for the accumulated solids in the filtration section. This behavior may be due to the lower mean size of the accumulated solids in this section. 
The BMP test of the permeate was carried out at psychrophilic conditions $\left(16^{\circ} \mathrm{C}\right)$, obtaining a SMY of $284.3 \pm 1.8 \mathrm{mLCH}_{4} /\left(\mathrm{gVS}_{\mathrm{fed}}\right)$. The biodegradation curve only showed a rapidly biodegradable fraction, with a degradation rate of 56 $\mathrm{mLCH}_{4} /\left(\mathrm{gVS}_{\mathrm{fed}} \mathrm{d}\right)$. This different behavior of the methane accumulation curve was because the organic matter content in the permeate stream was composed of only soluble matter.

\subsection{Membrane cleaning and permeability}

In this study, the membrane was chemically cleaned after the first and second experiments. Different cleaning methods were used both times. Figure 5 shows the membrane characterization with tap water at $16^{\circ} \mathrm{C} \pm 1$, before the physical cleaning and after each type of cleaning that was conducted after the second experiment. Table 4 shows the membrane resistance after the membrane cleaning was performed after each of the experiments.

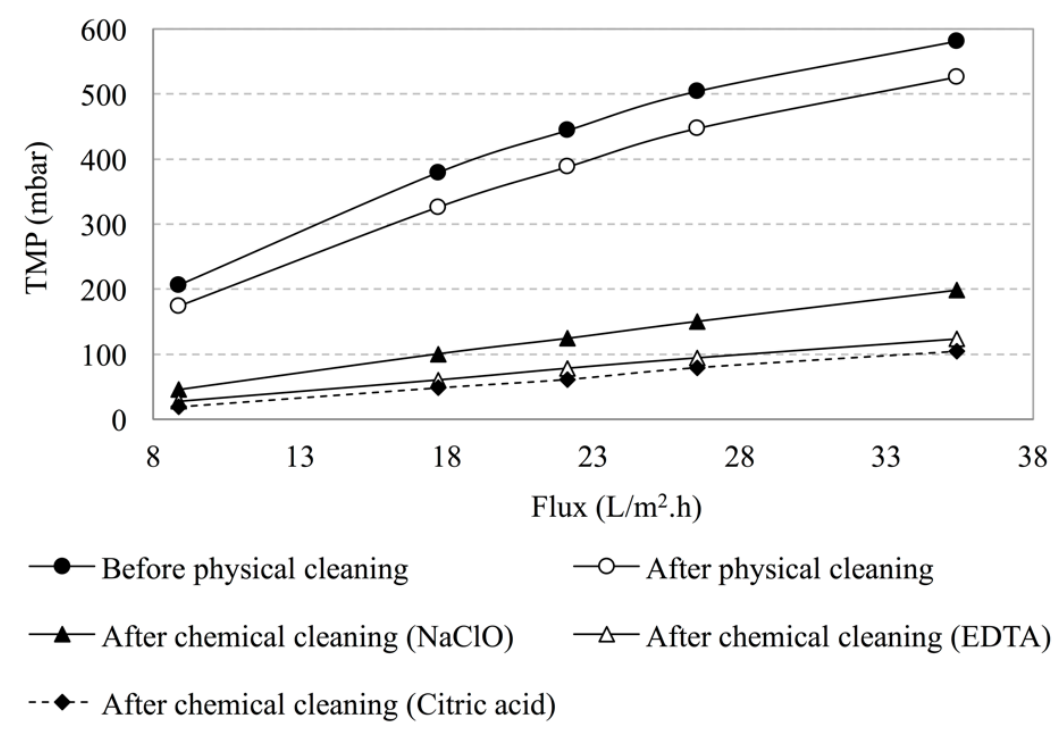

Figure 5 -Membrane characterization under different cleaning protocols after the second run. 
Table 4 - Membrane resistance after each cleaning method $\left(10^{12} \mathrm{~m}^{-1}\right)$

\begin{tabular}{cccccc}
\hline & No cleaning & Physical cleaning & \multicolumn{3}{c}{ Chemical cleaning } \\
Before DMF & & & NaClO & EDTA & Citric acid \\
\cline { 2 - 5 } & & - & 1.46 & - & - \\
After first run of DMF & 6.83 & 4.35 & 3.11 & - & - \\
After second run of DMF & 7.42 & 6.24 & 2.00 & 1.24 & 1.02 \\
\hline
\end{tabular}

As shown in Figure 5, the membrane permeability increased with the intensity of the cleaning procedure. When we were performing physical and chemical cleaning with different reagents, the membrane permeability increased from $0.05\left(\mathrm{~L} /\left(\mathrm{m}^{2}\right.\right.$ $\mathrm{h}) /(\mathrm{mbar})$ before physical cleaning, to $0.18\left(\mathrm{~L} /\left(\mathrm{m}^{2} \mathrm{~h}\right) /(\mathrm{mbar})\right.$ after the cleaning with $\mathrm{NaClO}$. Finally, after the cleaning with EDTA and citric acid, the membrane permeability increased to a value of $0.35\left(\mathrm{~L} /\left(\mathrm{m}^{2} \mathrm{~h}\right) /(\mathrm{mbar})\right.$. This latter permeability represents an enhancement of more than seven times with respect to the membrane permeability before being subjected to any cleaning procedure.

In terms of resistance, as shown in Table 4, the physical cleaning was ineffective. Membrane resistance decreased from $7.42 \times 10^{12} \mathrm{~m}^{-1}$ to $6.24 \times 10^{12}$ $\mathrm{m}^{-1}$, which represents only $15.9 \%$ of recovery. This result shows that most part of the membrane fouling was not removed by the physical method. On the other hand, the cleaning process with $\mathrm{NaClO}(1000 \mathrm{ppm})$ during 3 hours at $35^{\circ} \mathrm{C}$ produced a notable decrease in the membrane resistance. This decrease was from $6.24 \times 10^{12}$ to $2.0 \times$ $10^{12} \mathrm{~m}^{-1}$, which represents $68 \%$ of recovery, and shows that most of the membrane fouling was due to organic matter. This improvement was similar to the one reported by Gong et al. [28]. They worked with a polyvinylidene fluoride hollow-fiber membrane in a DMF process, reaching $75 \%$ of fouling removal after applying chemical cleaning with a solution of $\mathrm{NaClO}(350 \mathrm{ppm})$ for $36 \mathrm{~h}$.

In this work, the cleaning with EDTA and citric acid led to the recovery of the membrane by decreasing the membrane resistance to $1.02 \times 10^{12} \mathrm{~m}^{-1}$. This 
improvement represents $86 \%$ of total fouling removal with respect to the condition before physical cleaning and indicates the presence of inorganic fouling in the membrane. There was no significant decrease in the membrane resistance between the cleanings with EDTA and citric acid. This demonstrates that EDTA removes most part of the inorganic fouling as has already been shown by Porcelli et al. [35] due to the chelation capacity of the EDTA and citric acid. Ozgun et al. [36], who applied a polyethersulfone membrane to an anaerobic membrane bioreactor, reached $75 \%$ of fouling removal by sequentially soaking the mem- brane module in 200 ppm NaClO0.4\% Divos solution for $30 \mathrm{~min}$, and then in a $1 \%(\mathrm{w} / \mathrm{v})$ citric acid solution for one hour. In this study, despite working in a DMF system with pre-settled municipal wastewater, the membrane initial conditions were efficiently recovered by using a great chemical cleaning method. However, after all the chemical cleaning, the membrane per- meability was $0.35\left(\mathrm{~L} /\left(\mathrm{m}^{2} \mathrm{~h}\right) /(\mathrm{mbar})\right.$, which is a low value compared to $1.02\left(\mathrm{~L} /\left(\mathrm{m}^{2} \mathrm{~h}\right) /(\mathrm{mbar})\right.$ in the new membrane. The initial membrane permeability in this study was $0.23\left(\mathrm{~L} /\left(\mathrm{m}^{2} \mathrm{~h}\right) /(\mathrm{mbar})\right.$. This value was reached after subjecting the membrane to chemical cleaning ( $\mathrm{NaClO}, 500 \mathrm{ppm}$ ), because it had previously been working in an anaerobic MBR. When we compare this initial permeability to the one reached after approximately 100 days of direct filtration, and after cleaning, we observe a slight increase in the permeability from 0.23 to $0.35\left(\mathrm{~L} /\left(\mathrm{m}^{2} \mathrm{~h}\right) /(\mathrm{mbar})\right.$. This increase may be due to the more intense cleaning carried out after the DMF compared to the cleaning conducted with only $\mathrm{NaClO}$ before the DMF. The visual inspection of the membrane surface after the DMF showed that the fibers were not mechanically damaged. 


\subsection{Energy balance}

In order to determine a reliable cost analysis of the DMF process of municipal wastewater combined with the anaerobic treatment of each stream, under different temperature conditions, more studies should be carried operating throughout different filtration conditions at longer term. Nevertheless, to determine the feasibility of the DMF as an alternative to activated sludge process, a preliminary energy balance estimation was performed. The following assumptions: a permeate flux of 10 $\mathrm{L} /\left(\mathrm{m}^{2} \mathrm{~h}\right)$, a SGDp of $90 \mathrm{~m}^{3} / \mathrm{m}^{3}$ and a $35 \%$ electric conversion, were considered for the evaluation. In this balance, the energy consumption is ascribed to the gas compressor, and the energy production is due to the generated methane. The considered methane pro- duction comes from the anaerobic treatment of the accumulated solid streams and from the permeate stream. The former comes from the mesophilic anaerobic digestion of the accumulated VS $\left(0.323 \mathrm{~L} \mathrm{CH}_{4} / \mathrm{gVS}_{\text {fed }}\right)$, considering a retention rate of VS in the MT of $41 \%$, and the latter comes from the psychrophilic anaerobic treatment of the permeate stream $\left(0.284 \mathrm{~L} \mathrm{CH}_{4} / \mathrm{gVS}_{\text {fed }}\right)$. In this preliminary study, neither the energy consumption of the feed and filtration pumps, nor the costs of reagents for membrane cleaning have been considered. Under these conditions, the energy balance showed that the power produced from the generated methane is higher $\left(0.50 \mathrm{kWh} / \mathrm{m}^{3}\right.$ permeate $)$ than the energy consumption by the gas compressor $\left(0.34 \mathrm{kWh} / \mathrm{m}^{3}\right.$ permeate). The few energy balances estimation from the literature, carried out for different WWTPs diagrams, also showed the potential of this technology. Lateef et al. [20] concluded that if the membrane fouling is not so severe, the net energy balance in the wastewater treatment system with DMF may be positive. Mezohegyi et al. [23] concluded that the theoretical calculations for a full-scale operation showed that semi-continuous sewage up-concentration by membrane filtration can efficiently be run at realistic 
wastewater/filtration parameters, ensuring a retentate with a COD level that meets the economic benefits of the sequential anaerobic treatment.

\section{Conclusions}

DMF was proven to be a feasible technology to separate $\mathrm{PCOD}$ from municipal wastewater, enabling a true improvement in carbon content recovery, because the solid and the permeate streams can be anaerobically treated under different temperature conditions. Results show that it is possible to maintain the filtration process continuously for about 40 days before any membrane cleaning, with a moderate permeate flux of around $10 \mathrm{~L} /\left(\mathrm{m}^{2} \mathrm{~h}\right)$ and SGDp up to $90 \mathrm{~m}^{3} / \mathrm{m}^{3}$. The configuration of the MT was also an important issue to allow solids sedimentation without compromising the membrane performance. The concentration of TS that reached the sedimentation section was $45 \mathrm{~g} / \mathrm{L}$, while the filtration section did not reach more than $4.4 \mathrm{~g} / \mathrm{L}$ of TS. A preliminary energy balance shows that the energy consumption due to the gas compression is lower than the energy production from the generated methane. Nevertheless, more studies should be carried out in order to optimize variables affecting the filtration process and, therefore, the net recovered energy from the municipal wastewater.

\section{Acknowledgements}

The ultrafiltration membrane module (ZW-10 Zenon) was sup- plied by General Electric. The Environmental Technology group of Universidad de Valladolid is a 'Grupo de Excelencia' selected by the Regional Government of Castilla y León (UIC 071). 


\section{Funding}

Thiago Antonio would like to thank the Conselho Nacional de Desenvolvimento Científico e Tecnológico (CNPq, National Council for the Scientific and Technological

Development, Brazil), for his PhD scholarship.

\section{References}

[1] C. Prasse, D. Stalter, U. Schulte-OehImann, J. OehImann, T.A. Ternes, Spoilt for choice: A critical review on the chemical and biological assessment of current wastewater treatment technologies, Water Res. 87 (2015) 237-270. doi:10.1016/j.watres.2015.09.023.

[2] P.L. McCarty, J. Bae, J. Kim, Domestic wastewater treatment as a net energy producer-can this be achieved?, Environ. Sci. Technol. 45 (2011) 7100-7106. doi:10.1021/es2014264.

[3] I. Vera, K. Sáez, G. Vidal, Performance of 14 full-scale sewage treatment plants: Comparison between four aerobic technologies regarding effluent quality, sludge production and energy $\begin{array}{lllll}\text { consumption, } & \text { Environ. } & \text { Technol. } & 34 & \text { (2013) }\end{array}$ doi:10.1080/09593330.2013.765921.

[4] K. Mizuta, M. Shimada, Benchmarking energy consumption in municipal wastewater treatment plants in Japan, Water Sci. Technol. 62 (2010) 2256-2262. doi:10.2166/wst.2010.510.

[5] W.Q. Guo, S.S. Yang, W.S. Xiang, X.J. Wang, N.Q. Ren, Minimization of excess sludge production by in-situ activated sludge treatment processes - A comprehensive review, Biotechnol. Adv. 31 (2013) 1386-1396. doi:10.1016/j.biotechadv.2013.06.003.

[6] E. Dulekgurgen, S. Doğruel, Ö. Karahan, D. Orhon, Size distribution of wastewater COD fractions as an index for biodegradability, Water Res. 40 (2006) 273-282. doi:10.1016/j.watres.2005.10.032.

[7] J. Wu, G. Yan, G. Zhou, T. Xu, Wastewater COD biodegradability fractionated by simple physicalchemical analysis, Chem. Eng. J. 258 (2014) 450-459. doi:10.1016/j.cej.2014.07.106.

[8] R.M. Mckeown, D. Hughes, G. Collins, T. Mahony, V. O'Flaherty, Low-temperature anaerobic digestion for wastewater treatment, Curr. Opin. Biotechnol. 23 (2012) 444-451. doi:10.1016/j.copbio.2011.11.025.

[9] G. Lettinga, S. Rebac, G. Zeeman, Challenge of psychrophilic anaerobic wastewater treatment, Trends Biotechnol. 19 (2001) 363-370. doi:10.1016/S0167-7799(01)01701-2.

[10] J.A. Álvarez, E. Armstrong, M. Gomez, M. Soto, Anaerobic treatment of low-strength municipal wastewater by a two-stage pilot plant under psychrophilic conditions, Bioresour. Technol. 99 (2008) 7051-7062. doi:10.1016/j.biortech.2008.01.013.

[11] S. Chong, T.K. Sen, A. Kayaalp, H.M. Ang, The performance enhancements of upflow anaerobic sludge blanket (UASB) reactors for domestic sludge treatment - A State-of-the-art review, Water Res. 46 (2012) 3434-3470. doi:10.1016/j.watres.2012.03.066.

[12] B. Lew, I. Lustig, M. Beliavski, S. Tarre, M. Green, An integrated UASB-sludge digester system for raw domestic wastewater treatment in temperate climates, Bioresour. Technol. 102 (2011) 
4921-4924. doi:10.1016/j.biortech.2011.01.030.

[13] M. Takahashi, T. Yamaguchi, Y. Kuramoto, A. Nagano, S. Shimozaki, H. Sumino, N. Araki, S. Yamazaki, S. Kawakami, H. Harada, Performance of a pilot-scale sewage treatment: An up-flow anaerobic sludge blanket (UASB) and a down-flow hanging sponge (DHS) reactors combined system by sulfur-redox reaction process under low-temperature conditions, Bioresour. Technol. 102 (2011) 753-757. doi:10.1016/j.biortech.2010.08.081.

[14] K.S. Singh, T. Viraraghavan, Municipal Wastewater Treatment by UASB Process: Start-up at $20^{\circ} \mathrm{C}$ and Operation at Low Temperatures, Environ. Technol. 25 (2004) 621-634. doi:10.1080/09593330.2004.9619352.

[15] J. Hoinkis, S.A. Deowan, V. Panten, A. Figoli, R.R. Huang, E. Drioli, Membrane Bioreactor (MBR) Technology - a Promising Approach for Industrial Water Reuse, Procedia Eng. 33 (2012) 234241. doi:10.1016/j.proeng.2012.01.1199.

[16] N.S.A. Mutamim, Z.Z. Noor, M.A.A. Hassan, G. Olsson, Application of membrane bioreactor technology in treating high strength industrial wastewater: a performance review, Desalination. 305 (2012) 1-11. doi:10.1016/j.desal.2012.07.033.

[17] P. Niren, P. Jigisha, Textile wastewater treatment using a UF hollow-fibre submerged membrane bioreactor (SMBR)., Environ. Technol. $32 \quad$ (2011) 1247-57. doi:10.1080/09593330.2010.534821.

[18] S.J. Judd, The status of industrial and municipal effluent treatment with membrane bioreactor technology, Chem. Eng. J. (2015). doi:10.1016/j.cej.2015.08.141.

[19] F.R. Spellman, Handbook of water and wastewater treatment plant operations, 3rd ed., CRC Press, Boca Raton, 2013.

[20] S.K. Lateef, B.Z. Soh, K. Kimura, Direct membrane filtration of municipal wastewater with chemically enhanced backwash for recovery of organic matter, Bioresour. Technol. 150 (2013) 149-155. doi:10.1016/j.biortech.2013.09.111.

[21] Z. Jin, H. Gong, H. Temmink, H. Nie, J. Wu, J. Zuo, K. Wang, Efficient sewage pre-concentration with combined coagulation microfiltration for organic matter recovery, Chem. Eng. J. 292 (2016) 130-138. doi:10.1016/j.cej.2016.02.024.

[22] S. Delgado Diaz, L. Vera Peña, E. González Cabrera, M. Martínez Soto, L.M. Vera Cabezas, L.R. Bravo Sánchez, Effect of previous coagulation in direct ultrafiltration of primary settled municipal wastewater, Desalination. 304 (2012) 41-48. doi:10.1016/j.desal.2012.08.005.

[23] G. Mezohegyi, M.R. Bilad, I.F.J. Vankelecom, Direct sewage up-concentration by submerged aerated and vibrated membranes, Bioresour. Technol. 118 (2012) 1-7. doi:10.1016/j.biortech.2012.05.022.

[24] A.M. Ravazzini, A.F. van Nieuwenhuijzen, J.H.M.J. van der Graaf, Direct ultrafiltration of municipal wastewater: Comparison between filtration of raw sewage and primary clarifier effluent, Desalination. 178 (2005) 51-62. doi:10.1016/j.desal.2004.11.028.

[25] T. Hey, J. Väänänen, N. Heinen, J. la Cour Jansen, K. Jönsson, Potential of combining mechanical and physicochemical municipal wastewater pre-treatment with direct membrane filtration, Environ. Technol. 38 (2016) 108-115. doi:10.1080/09593330.2016.1186746.

[26] APHA, Standard Methods for the Examination of Water and Wastewater, 2005. 
doi:10.2105/AJPH.51.6.940-a.

[27] I. Angelidaki, M. Alves, D. Bolzonella, L. Borzacconi, J.L. Campos, A.J. Guwy, S. Kalyuzhnyi, P. Jenicek, J.B. Van Lier, Defining the biomethane potential (BMP) of solid organic wastes and energy crops: A proposed protocol for batch assays, Water Sci. Technol. 59 (2009) 927-934. doi:10.2166/wst.2009.040.

[28] H. Gong, Z. Jin, X. Wang, K. Wang, Membrane fouling controlled by coagulation/adsorption during direct sewage membrane filtration (DSMF) for organic matter concentration, J. Environ. Sci. (China). 32 (2015) 1-7. doi:10.1016/j.jes.2015.01.002.

[29] Z. Jin, H. Gong, K. Wang, Application of hybrid coagulation microfiltration with air backflushing to direct sewage concentration for organic matter recovery, J. Hazard. Mater. 283 (2015) 824831. doi:10.1016/j.jhazmat.2014.10.038.

[30] S. Judd, C. Judd, The MBR Book: Principles and Applications of Membrane Bioreactors for Water and Wastewater Treatment, 2nd ed., Butterworth-Heinemann, Oxford, UK, 2011. doi:10.1016/B978-0-08-096682-3.10007-1.

[31] J. Ma, Z. Wang, Y. Xu, Q. Wang, Z. Wu, A. Grasmick, Organic matter recovery from municipal wastewater by using dynamic membrane separation process, Chem. Eng. J. 219 (2013) 190199.

[32] S. Astals, M. Esteban-Gutiérrez, T. Fernández-Arévalo, E. Aymerich, J.L. García-Heras, J. MataAlvarez, Anaerobic digestion of seven different sewage sludges: A biodegradability and modelling study, Water Res. 47 (2013) 6033-6043. doi:10.1016/j.watres.2013.07.019.

[33] C. Eskicioglu, A. Prorot, J. Marin, R.L. Droste, K.J. Kennedy, Synergetic pretreatment of sewage sludge by microwave irradiation in presence of $\mathrm{H} 2 \mathrm{O} 2$ for enhanced anaerobic digestion, Water Res. 42 (2008) 4674-4682. doi:10.1016/j.watres.2008.08.010.

[34] K.Y. Park, H.M. Jang, M.-R. Park, K. Lee, D. Kim, Y.M. Kim, Combination of different substrates to improve anaerobic digestion of sewage sludge in a wastewater treatment plant, Int. Biodeterior. Biodegradation. 109 (2016) 73-77. doi:10.1016/j.ibiod.2016.01.006.

[35] N. Porcelli, S. Judd, Chemical cleaning of potable water membranes: A review, Sep. Purif. Technol. 71 (2010) 137-143. doi:10.1016/j.seppur.2009.12.007.

[36] H. Ozgun, Y. Tao, M.E. Ersahin, Z. Zhou, J.B. Gimenez, H. Spanjers, J.B. van Lier, Impact of Temperature on Feed-flow Characteristics and Filtration Performance of an Upflow Anaerobic Sludge Blanket Coupled Ultrafiltration Membrane Treating Municipal Wastewater, Water Res. 83 (2015) 71-83. doi:10.1016/j.watres.2015.06.035. 
CHAPTER 5 | Improvement of municipal wastewater pretreatment by DMF 



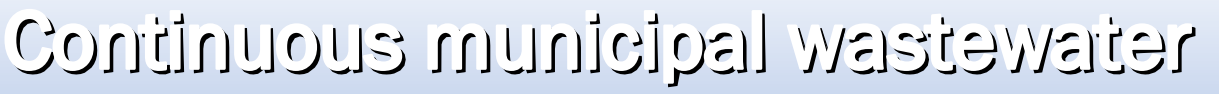 Lp-cosscendsoujos by oljaect snensoranse fildraidon, consideringe the effect of internititent gas scouring and threshold flux determination}

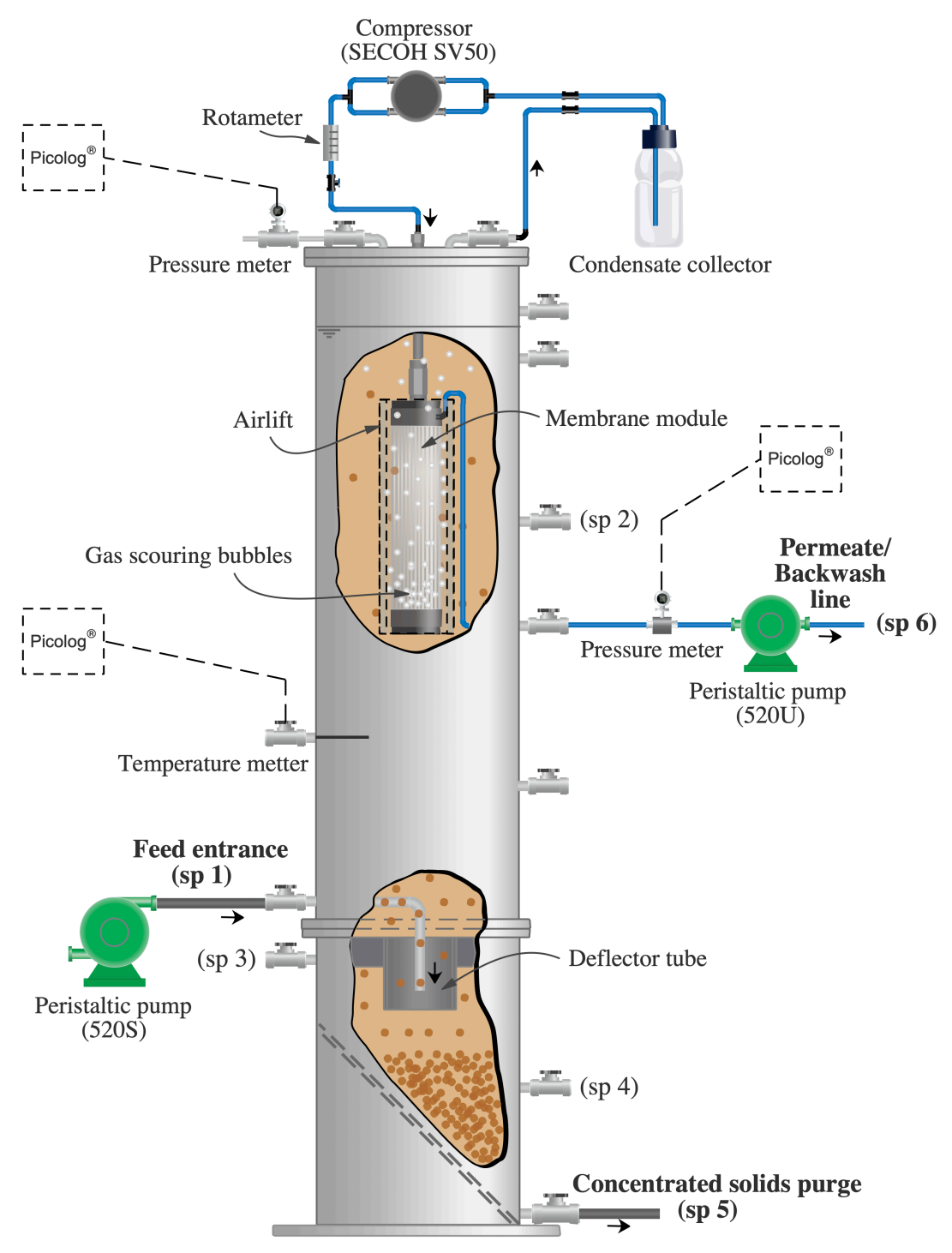





\title{
Continuous municipal wastewater up-concentration by direct membrane filtration, considering the effect of intermittent gas scouring and threshold flux determination
}

\author{
Thiago A. Nascimentoa*, Mar Peña Mirandaa \\ a Department of Chemical Engineering and Environmental Technology, University of Valladolid \\ a Institute of Sustainable Processes, University of Valladolid, Dr. Mergelina s/n, 47011 Valladolid, \\ Spain \\ *Corresponding author. Tel.: +34 983423166. E-mail address: thiagoantonio.br@gmail.com
}

\section{Abstract}

Municipal wastewater is recognized as having a high amount of biodegradable matter which is not easily hydrolyzed through anaerobic treatments in cold climate countries. Under proper operating conditions, the direct membrane filtration (DMF) appears to be a feasible technology, capable of efficiently separating and concentrating the primary wastewater for subsequent anaerobic digestion under mesophilic conditions. The long-term operation of a municipal wastewater concentration process was proved feasible with intermittent gas scouring (40 s of operation followed by a pause of 3.5 min) and permeate backwash. Operating at $12.7 \mathrm{~L} / \mathrm{m}^{2} . \mathrm{h}$ feed with medium strength wastewaters, a permeate stream below the discharge limit was obtained, and the resulting concentrate streams presented levels of between 19,000 and $54,000 \mathrm{mg} / \mathrm{L}$ of COD. An estimated energy balance pointed to the self-sufficiency of the process by allowing for an energy production of $0.19 \mathrm{kWh} / \mathrm{m}^{3}$ through the anaerobic digestion, while the power consumption for the gas scouring and pumping resulted in 0.15 $\mathrm{kWh} / \mathrm{m}^{3}$. Experiments demonstrated that the threshold flux for a wastewater filtration is highly influenced by the gas scouring velocity. The operation performed with 32.9 gTSS/L of primary concentrated wastewater indicated that the threshold fluxes increase by more than $300 \%$ through increasing the gas scouring velocities from 0 to $30.6 \mathrm{~m} / \mathrm{h}$.

Keywords: primary wastewater concentration, organic matter recovery, anaerobic digestion, ultrafiltration membrane. 


\section{Introduction}

A wide range of sustainable processes for municipal wastewater (MW) treatment have been studied and encouraged in order to improve or replace conventional systems in several wastewater treatment plants worldwide, either to save energy, to recover nutrients, or to reduce environmental impacts [1,2]. Typical plants for MW treatment are based on the activated sludge (AS) process, which, despite its effectiveness, presents downsides including a high amount of energy expenditure, of around $0.2-2 \mathrm{kWh} / \mathrm{m}^{3}[3,4]$, high excess sludge production [5] and the wasting of valuable organic content embedded in MW streams [6] which carries the potential to make the wastewater treatment plants self-sufficient $[7,8]$. All these authors have mentioned that there are several opportunities for energy savings in the current MW treatment plants, from improvement in management practices to a better recovery of organic solids.

The anaerobic processes comprise the most prominent strategy capable of taking full advantage of the organic content from MW, and their application either as standalone or combined processes should be further strengthened for MW treatment in both developed and developing countries [9], because of their low environmental impact, such as the reduction in greenhouse gas (GHG) emissions, and the potential positive net energy production by means of biogas cogeneration. However, the direct application of anaerobic processes to treat municipal wastewater faces some major drawbacks such as a high fraction of particulate COD, moderate biodegradability, and low strength with varying concentrations and, usually, low temperatures.

In this sense, anaerobic membrane bioreactors (AnMBR) have been shown as potential technologies capable of uniting both energy savings and minimal environmental impact. Nevertheless, important challenges remain, jeopardizing the

efficiency of their application. These challenges are mostly related to low 
temperature, low rate of particulate matter biodegradation, membrane fouling, and the energy required for recirculation and crossflow velocity $[10,11]$.

At this point, it is clear that a technology capable of separating and concentrating the particulate fraction from municipal wastewater would enhance the treatment by enabling the appropriate recovery of carbon content through the direct conveyance to anaerobic digestion under mesophilic/thermophilic conditions. This has been the approach taken by many researchers, and some recent reviews have already been prepared in order to bring this theme into a broader discussion [1214]. Different technologies are being studied in order to pre-concentrate the MW, such as high-rate activated sludge system for carbon recovery $[15,16]$, chemical enhanced primary treatment (CEPT) [17], dynamic membrane [18,19], direct osmosis [20,21] and direct membrane filtration (DMF) [22-26]. Direct membrane filtration has been the subject of growing interest as a prominent process for the MW up-concentration by solving the problems associated with low temperature and power consumption. Therefore, the objective of the DMF is to obtain a compact and loaded stream with high carbon content to be conveyed for biogas conversion and a major permeate stream with soluble COD and nutrients. Another process, based on the coagulation adsorption enhanced membrane (CAEM) method, which redesigns the $\mathrm{C}$ and $\mathrm{N}$ mass flows for energy-neutral wastewater treatment, has also been studied [27].

The advantages of the DMF system are related to its extreme compactness, small footprint, and reduced energy consumption. Moreover, the high concentrations of solids reached during the direct membrane filtration, which can be digested to produce energy, is a relevant feature when compared to the conventional activated sludge systems without the concentration process. Thus, it can be expected that the direct membrane processes facilitate the achievement of better carbon neutrality 
values by simultaneous addressing both wastewater treatment and, in some cases, nutrient recovery through the addition of chemical reagents [28]. However, it is necessary to study the DMF process since there are few studies that have been conducted under continuous operation, and most of these were carried out on a short term, laboratory scale. These limitations make it difficult to determine the operating parameters and the feasibility of the process $[29,30]$. Therefore, the assessment of DMF operations for organic recovery from MW on larger, long term scales are still necessary. Moreover, assessment is required to determine the success of the DMF implementation depending on the strategies used to maintain the membrane module in operation by combining reasonable permeate fluxes and safe transmembrane pressures (TMP) without compromising the membrane itself and, at the same time, being able to fulfill their main goals.

From the theoretical point of view, the critical flux value is an important piece of information which is necessary in order to perform a safe and feasible DMF process. Critical flux can be defined as the flux below which no fouling affects the filtration process in a short period of time or, in other words, the flux from which the cake layer formation starts to be noticeable or variable with time dTMP/dt $\neq 0$ in its strong definition as stated by Field et al. [31] However, at long-term operation both for real and synthetic wastewaters [32], the membrane fouling is perceived as a result of the accumulation of reversible and irreversible fouling even under subcritical conditions, which is an inherent characteristic of dead-end processes. From a practical point of view, and in order to provide useful guidance, the concept of threshold flux $\left(\mathrm{J}_{\mathrm{t}}\right)$ is hereby implemented for the DMF operation as a flux at or below which a low and near constant rate of fouling occurs, but above which the rate of fouling markedly increases [33]. An immediate consequence of the threshold flux is the more subjective, yet useful, concept of sustainable flux which is defined as the 
net flux that can be maintained under the conditions particular to antifouling strategies, considering an optimum balance of the operating costs [34]. Therefore, considering a feasible long-term operation of DMF system and putting into perspective the pragmatic threshold and sustainable fluxes, membrane fouling is a great concern and therefore antifouling strategies have been the subject of discussion over the last years [25,35]. Different methods have been tested in order to avoid fouling during the MW concentration, and their actions vary from producing large, loose particles of solids, using coagulation/flocculation processes, providing a shear force that detaches the cake layer from the membrane surface, using air/gas scouring [36,37] and also the application of permeate backwash and chemically enhanced backwash as strategies to minimize irreversible fouling [24]. The aforementioned strategies are the most common that have been found in literature up until now, and studies have reported good results when applying different arrangements of these antifouling methods.

Within this framework, the aim of this work is to evaluate the feasibility of MW up-concentration in a continuous process by ultrafiltration membranes (DMF process), while strategies like permeate backwash, intermittent gas scouring, and periodical purging of the concentrate stream are being applied for fouling control. In order to simulate the DMF under more severe conditions, the threshold fluxes are studied with highly concentrated MW. The energy balance of membrane consumption and biogas generation is calculated.

\section{Materials and Methods}

\subsection{Membrane module setup}

The membrane module used in the experiments is a hollow fiber type (ZW-10 Zenon, GE) with a mean pore size of $0.04 \mu \mathrm{m}$ and filtration area of $0.93 \mathrm{~m}^{2}$. At the 
bottom of the module there is a diffuser of coarse bubbles that provides the gas scouring to the membrane fibers. The gas scouring flux was controlled by a rotameter.

\subsection{Threshold flux setup}

The $\mathrm{J}_{\mathrm{t}}$ determination for the DMF of MW was performed in short-term experiments following a flux-step method, in which the filtration flux was increased until the variation of TMP suffered a noticeable slope change. The filtration flow was initially set at $2 \mathrm{~L} / \mathrm{h}$ and then subsequently increased by steps of $2 \mathrm{~L} / \mathrm{h}$. Before each filtration, the membrane was backwashed with clean water for $30 \mathrm{~s}$ with the same flux of filtration, and then the membrane started to filtrate for a fixed period of $5 \mathrm{~min}$.

The wastewater used in these experiments was collected from the downstream section of the grit chamber stage of the WWTP from the small town of Renedo de Esgueva (Spain). The plant process is based on an activated sludge system.

Previously to the experiment, several stages of decantation and filtration were used to up concentrate two volumes of raw wastewater, $1.2 \mathrm{~m}^{3}$ and $2.4 \mathrm{~m}^{3}$, resulting in two volumes of $16 \mathrm{~L}$ with $18.6 \mathrm{~g}$ TSS/L and $32.9 \mathrm{~g}$ TSS/L, respectively. These samples of concentrated raw wastewater were then used with the consideration that they could be achieved during the MW up-concentration process by operating as a long-term continuous process. The $\mathrm{J}_{\mathrm{t}}$ was determined for the two concentrations of wastewater, as well as different superficial gas velocities $\left(V_{G}\right)$ for each concentration (0; 10.2; 20.4 and $30.6 \mathrm{~m} / \mathrm{h})$. The experiments were conducted in a PVC cylindrical tube of $0.15 \mathrm{~m}$ in diameter, and $1.8 \mathrm{~m}$ high. In order to maintain a constant solid concentration in the bulk of the wastewater inside the tube, the filtrations were performed in a closed circuit so as to return the permeate effluent to the PVC cylinder. The superficial gas velocity was calculated, taking into account the transversal area 
of the PVC cylinder. The permeate line was equipped with a pressure transmitter (Endress + Hauser, PMC 131, -1 to 1 bar, Valladolid, ES) and, during the experiments, the MW samples remained constant at $20^{\circ} \mathrm{C}$.

\subsubsection{Membrane cleaning}

Before each experiment, with the different solid concentrations (18.6 g TSS/L and $32.9 \mathrm{~g} \mathrm{TSS} / \mathrm{L}$ ), the membrane module was chemically cleaned, and its permeability was then determined. Each chemical cleaning consisted of 4 stages including 1 physical cleaning (tap water jet and soft sponge) and 3 chemical cleanings (soaking for $2 \mathrm{~h}$ in 1000 ppm NaClO while undergoing agitation with air blowing; repeat procedure; followed by soaking for $2 \mathrm{~h}$ in $1.0 \%(\mathrm{w} / \mathrm{v})$ citric acid under agitation).

Moreover, during the experiment with the same solid concentration, but changing the superficial gas velocities, the membrane module was only physically cleaned out of place with a jet of tap water and a soft sponge, and following this its permeability was also determined.

\subsubsection{Membrane permeability}

The permeability of the membrane after the short-term flux step method was determined. A PVC cylindrical tube with clean water at $20^{\circ} \mathrm{C}$ was used for the characterization. The procedure used for the permeability determination consisted of measuring the TMP response in accordance with the applied filtration fluxes. 


\subsection{Long-term continuous municipal wastewater concentration process by direct membrane filtration}

The municipal wastewater concentration process was carried out in a continuously operating pilot plant. The characteristics of the wastewater feed are presented in Table 1.

Table 1 - Wastewater feed and permeate characteristics.

\begin{tabular}{ccc}
\hline & Feed & Permeate \\
\hline$t \operatorname{COD}(\mathrm{mg} / \mathrm{L})$ & $415( \pm 186)$ & $64( \pm 43)$ \\
$\operatorname{sCOD}(\mathrm{mg} / \mathrm{L})$ & $76( \pm 43)$ & $64( \pm 19)$ \\
$T S(\mathrm{mg} / \mathrm{L})$ & $1885( \pm 440)$ & $1518( \pm 129)$ \\
$V S(\mathrm{mg} / \mathrm{L})$ & $694( \pm 334)$ & $395( \pm 53)$ \\
$T S S(\mathrm{mg} / \mathrm{L})$ & $244( \pm 107)$ & $0( \pm 0)$ \\
$V S S(\mathrm{mg} / \mathrm{L})$ & $208( \pm 80)$ & $0( \pm 0)$
\end{tabular}

The discharge limit for the treated urban wastewater is $125 \mathrm{mg} / \mathrm{L} \mathrm{COD.} \mathrm{Data} \mathrm{in} \mathrm{brackets} \mathrm{are} \mathrm{the}$ standard deviations.

The pilot plant was composed of a vertical polypropylene tank, $1.76 \mathrm{~m}$ in height and $0.34 \mathrm{~m}$ in diameter, with a useful volume of $126 \mathrm{~L}$. As indicated in Fig. 1, the hollow fiber membrane module (ZW-10 Zenon, GE) is placed within the upper section of this tank. In the continuous experiments, the membrane was surrounded by an airlift (a cylindrical protector made of PVC, $0.15 \mathrm{~m}$ in diameter and $0.69 \mathrm{~m}$ in height). The airlift length completely covers the extension of the membrane module. The membrane tank has several sampling points (sp), which were used for sampling in this experiment: the feed entrance to the membrane tank (sp 1), the filtration section ( $s p 2$ ), the control of the concentrate section ( $s p 3, s p 4$, and $s p 5$ ) and, the permeate line (sp 6).

Peristaltic pumps were used for the feed (Watson Marlon 520S) and filtration/backwash line (Watson Marlon 520U). The feed wastewater (sp 1) is 
conducted through a centrical tube to the bottom of the membrane tank. This centrical tube works as a deflector by hindering the larger particles from rising out of the feed wastewater and into the filtration section. The feed wastewater (sp 1) reaches the center and is directed downwards. The sedimentation/concentration section comprises a total volume of $32.9 \mathrm{~L}$ between the feed entrance (sp 1) and the bottom of the membrane tank (sp 5). The concentrated solids are periodically purged from the lower section (sp 5).

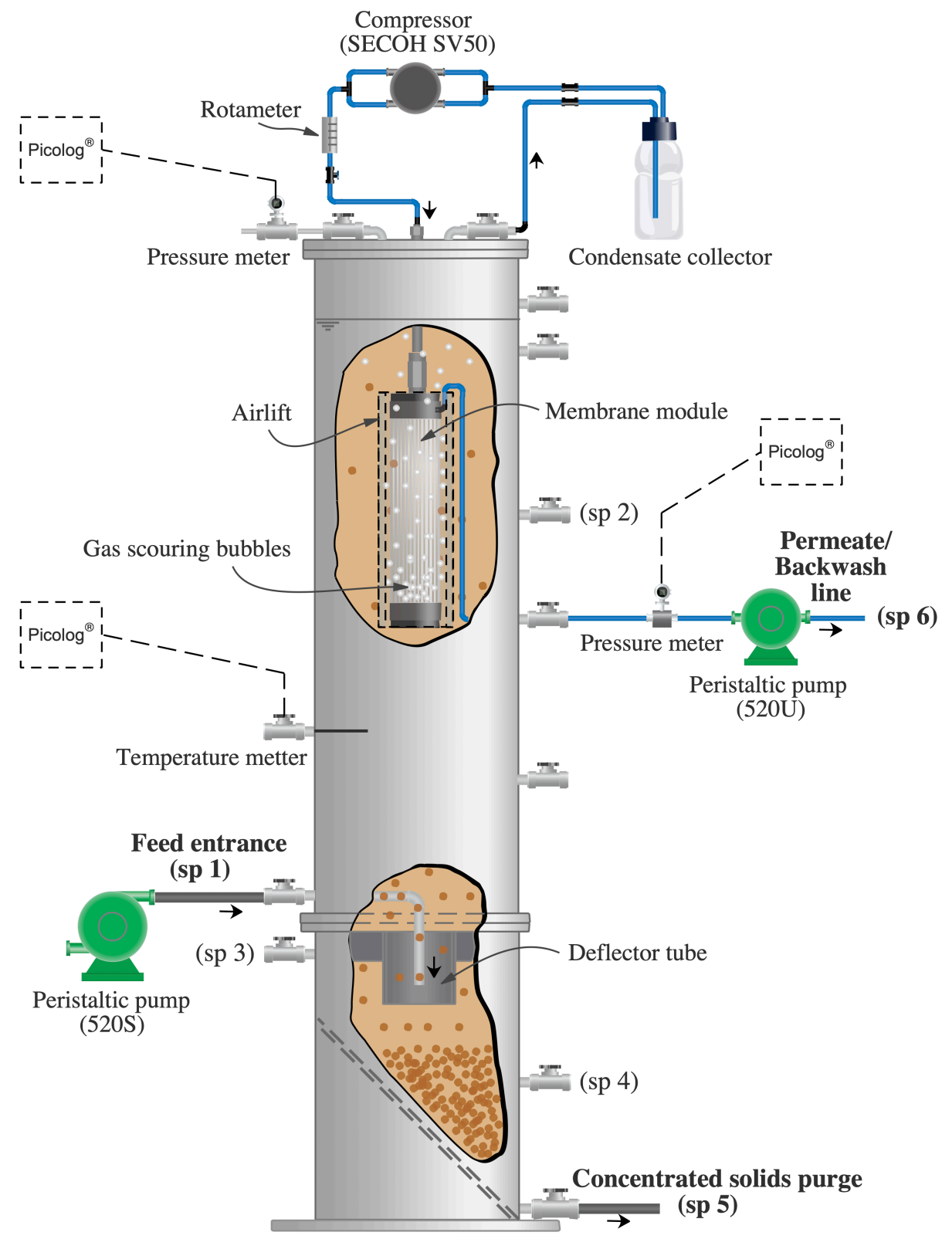

Figure 1 - Schematic representation of the membrane tank used in the long-term DM. The cylinder and the internal elements are practically to scale 
In order to keep the membrane in continuous operation, permeate backwash and intermittent gas scouring were used as antifouling methods. The filtration cycle was composed of four periods: 0.5 min backwash, $5 \mathrm{~s}$ pause, 7 min filtration and $5 \mathrm{~s}$ pause again. Therefore, the filtration time corresponded to $91.3 \%$ of the total filtration cycle. The membrane module was subjected to scouring provided by closed circuit recirculation in the headspace of the membrane tank using a compressor (SECOH, SV50, Barcelona, ES).

The gas velocity was calculated by taking into account the established gas flow through the transversal area of the airlift. The velocity was controlled using a rotameter and the compressor regime was set to operate intermittently using a timer control, for $40 \mathrm{~s}$ of operation time followed by a $3.5 \mathrm{~min}$ pause. The plant was equipped with pressure transmitters (Endress + Hauser, PMC 131, -1 to 1 bar, Valladolid, ES) in the permeate/backwash line and in the headspace of the membrane tank. The Picolog Technology Ltd. data acquisition system was used to monitor and store the data regarding temperature and filtration pressures.

\subsection{Chemical assays and sampling}

Total COD, soluble COD, total solids (TS), volatile solids (VS), total suspended solids (TSS) and volatile suspended solids (VSS) were determined according to the Standard Methods for the Examination of Water and Wastewater [38]. Samples for the long-term operation process were collected periodically (every 2 days approx.) from the sampling points labelled sp1, sp5 and sp6 in order to monitor the concentration process. 


\subsection{Biochemical methane potential assay}

Biochemical methane potential assays $(\mathrm{BMP})$ at mesophilic $\left(35.1 \pm 0.3^{\circ} \mathrm{C}\right)$ conditions were carried out in order to assess the biodegradability of the concentrated solids from the primary wastewater purged in the lower section of the membrane tank (sp 5). The tests were performed in triplicate, the anaerobic inoculum used was obtained from a pilot sludge digester and pre-incubated for two days (35.1 $\pm 0.3^{\circ} \mathrm{C}$ ) to minimize its residual biodegradable organic matter content. A blank test without substrate was included. Serum bottles with a volume of $160 \mathrm{~mL}$ were used in the BMP tests, with a reaction volume of $80 \mathrm{~mL}$. The inoculum ratio $(\mathrm{S} / \mathrm{X})$ was 0.4 gVSS $_{\text {subs/gVSS }}$ inoc. The bottles were sealed, using rubber septa and aluminum crimp caps, and then gassed with Helium, and subjected to continuous agitation in an orbital shaker. Biogas production was estimated by measuring the pressure in the headspace of the bottles and the biogas composition. Biogas composition was analyzed using a gas chromatograph (Varian, CP-3800, Palo Alto, CA, USA) coupled with a thermal conductivity detector and equipped with a CP-Molsieve 5A (15 m x $0.53 \mathrm{~mm} \times 15 \mu \mathrm{m})$ and CP-Pora BOND Q (25 m x $0.53 \mathrm{~mm} \times 15 \mu \mathrm{m})$ columns.

The specific methane yield (SMY), $\mathrm{mL} \mathrm{CH}_{4} / \mathrm{gVS}_{\mathrm{fed}}$ was calculated by dividing the net methane production associated with the substrate by the quantity of volatile solids from the substrate at the beginning of the test.

\section{Results and Discussion}

\subsection{Threshold flux determination using primary wastewater sludge}

\subsubsection{The effect of gas scouring and solid concentrations}

The graphics shown in Fig. 2 are the results of the $J_{t}$ determination. For each $\mathrm{J}_{\mathrm{t}}$ determination, the fluxes are increased until the TMP reached a maximum value of 400 mbar. This value was chosen as a safe working pressure in order not to damage 
the membrane module and, even when the $\mathrm{J}_{\mathrm{t}}$ was reached with TMP under $400 \mathrm{mbar}$, except in one case (Fig. 2f), the filtration fluxes were still raised up to 400 mbar in order to appreciate the increasing slopes.

The adopted arbitrary limit for the $\mathrm{J}_{\mathrm{t}}$ determination was based on the observed slope values for the graphics TMP (mbar) vs Time (min) (dTMP/dt), in accordance with the procedure followed by other authors [39-41]. The criterion established here is that the threshold flux is the flux at which dTMP/dt is immediately inferior to the unit, as presented in Fig. 2. According to this assumption, the $\mathrm{J}_{t}$ can never promote an increase of $1 \mathrm{mbar} / \mathrm{min}$. This consideration, for the current experiment, allows the threshold flux variation to be determined without incurring qualitative error, besides establishing a fouling rate which can be appreciated through observation.

The gas scouring velocity and the solid concentrations in wastewater have a remarkable effect on the membrane surface and hence in the obtained threshold fluxes. When comparing the $\mathrm{J}_{\mathrm{t}}$ for the two solid concentrations assayed, a notable increase is observed in the resulting $J_{t}$ as the superficial gas velocities increase. These increases in $\mathrm{J}_{\mathrm{t}}$, due to the increases of gas velocities, caused enhancements of $500 \%$ and $300 \%$, respectively, to the lower and higher concentrations. Besides, increasing the wastewater concentration severely affects the threshold fluxes for the same applied gas scouring. It is interesting to take note of the fact that for industrial purposes the balance between the sustainable permeate flux and the superficial gas velocities applied might be more valuable than the objective of reaching the maximum permeate flux, even though it means an extra operating cost. The operation with 18.6 gTSS/L wastewater seems to be achievable in a continuous process with low to medium filtration fluxes and TMP, and moderate gas scouring, as exemplified by the conditions of Figs. $2 \mathrm{~b}$ and $2 \mathrm{c}$. As reported by Gong et al. [42], the long-term ultrafiltration of municipal wastewater under high concentrations of TSS (above 20.0 
$\mathrm{g} / \mathrm{L}$ ) is feasible, employing enhanced-preconcentration and air-backflushing over a two-month operation period.
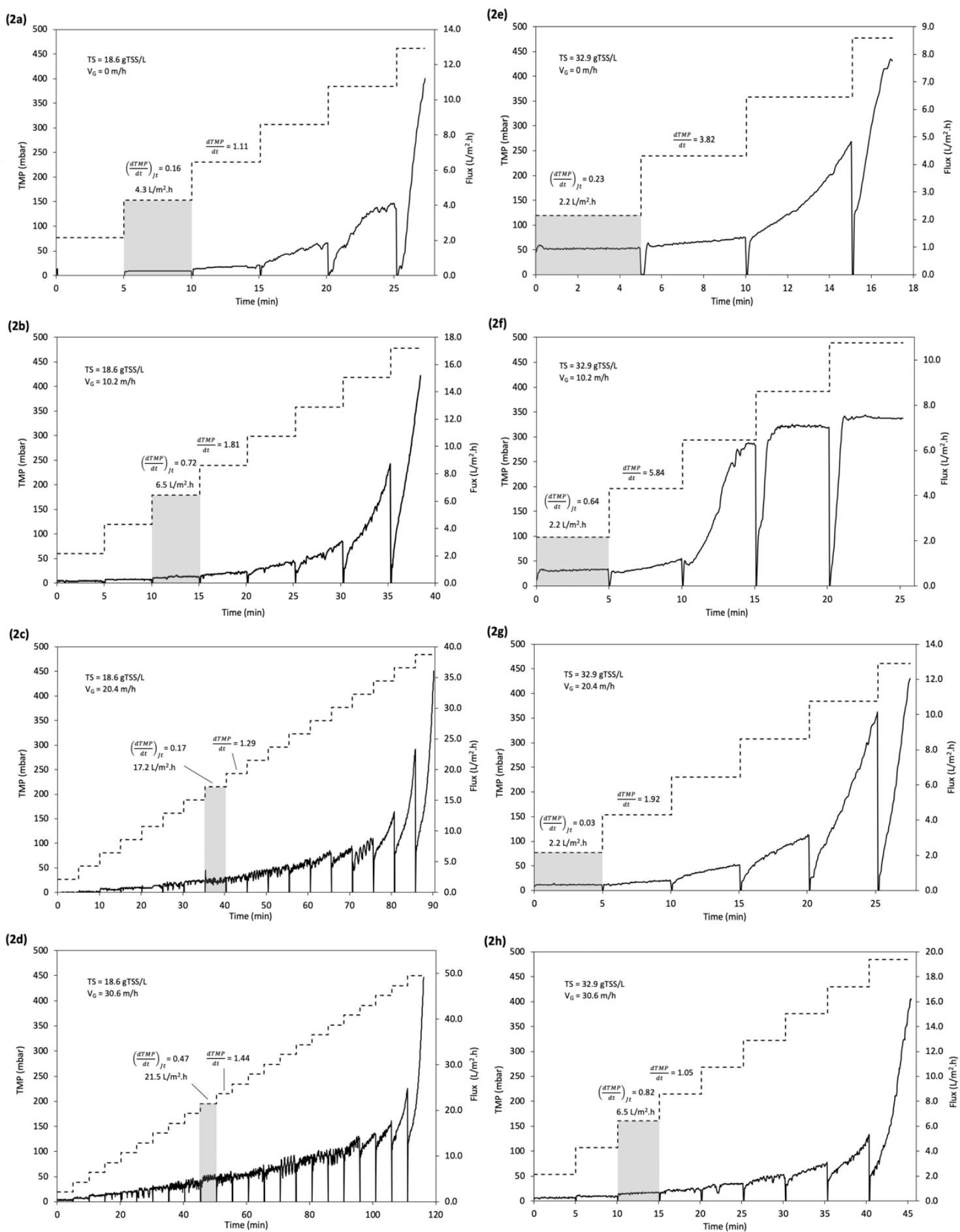

Figure 2 - Threshold flux behavior, operating with two up-concentrated primary wastewaters, 18.6 gTSS/L and 32.9 gTSS/L and with different gas scouring velocities, $V_{G}(0 ; 10.2 ; 20.4$ and $30.6 \mathrm{~m} / \mathrm{h})$ for each solid concentration. The dotted line represents the filtration fluxes $\left(L / m^{2} . h\right)$. 
The higher $\mathrm{J}_{\mathrm{t}}$ obtained for the first train of experiments is due to the ease of cleaning the membrane surface at this stage, since the solid concentration is lower and, therefore, the fouling layer is more fragile and more susceptible to being detached by the gas scouring. For the second train of experiments, with a solid concentration of 32.9 gTSS/L, the threshold fluxes determined were maintained at 2.2 $\mathrm{LMH}$ for the first three superficial gas velocities applied. The $\mathrm{J}_{t}$ only increased to 6.5 $\mathrm{LMH}$ when the superficial gas velocity was increased to $30.6 \mathrm{~m} / \mathrm{h}$, indicating that depending on the concentration of solids in raw wastewater, the $\mathrm{J}_{\mathrm{t}}$ may not have varied until a sufficient gas scouring velocity was applied to disturb the fouling layer on the membrane surface. From the data collected in all experiments, the critical flux in its strict concept was never attained. Even with the lower flux of $2.2 \mathrm{LMH}$, the $\mathrm{dTMP} / \mathrm{dt}$ values measured were positive, indicating some degree of fouling. This is precisely the conclusion of Le Clech et al. [32] who were operating a submerged membrane bioreactor with real and synthetic wastewaters. These authors indicate that there is a flux (a so-called weak form of critical flux) from which the fouling starts to be significant and, although difficult to determine with precision, it is useful for comparing fouling tendencies. These authors reported that these critical fluxes might be around $10 \mathrm{LMH}$ when working with $3 \mathrm{~g} / \mathrm{L}$ of MLSS concentration for the both the synthetic and real wastewaters investigated.

Furthermore, as found in this research, the membrane filtration without gas scouring usually leads to a rapid and accentuated dropping of the critical/threshold fluxes. Bottino et al. [43], working with a fixed $3 \mathrm{~L} / \mathrm{min}$ of air scouring, reported a decrease of 2.5 times in the critical flux by increasing the mixed liquor suspended solids (MLSS) from 3 to $14 \mathrm{~g} / \mathrm{L}$ after performing a submerged filtration with a polyethylene membrane in an MBR process. The authors also verified the same 
tendency by using a PVDF membrane; by changing the MLSS from 3 to $8 \mathrm{~g} / \mathrm{L}$, a decrease in the critical flux from 14.7 to $12.1 \mathrm{LMH}$ was obtained.

From the economical point of view, higher solid concentrations mean lower filtration fluxes and high demand for a higher superficial gas velocity, which leads the system to expend extra energy [44]. However, the concept of operating at subcritical or at/below the threshold flux seems to solve many of the concerns regarding submerged membranes for direct wastewater filtration. Investigations have been indicating that this approach brings the industrial processes into long term sustainable operation and that the benefits are diverse, comprising environmental protection, technical simplicity, and being economically attractive [34].

\subsubsection{Membrane permeability during the threshold flux determination}

The membrane module had been previously used in other experiments not mentioned in this work, so before using it for the $J_{t}$ determination it was soaked in clean water, and following chemical cleaning it presented an initial permeability of $0.72 \mathrm{mbar} / \mathrm{LMH}$. Throughout both experiments for the $\mathrm{J}_{\mathrm{t}}$ determination (the first one with 18.6 gTSS/L and the second one with 32.9 gTSS/L) the increase in the membrane fouling was also perceived by the decrease in its permeability, caused by the physical cleanings. In the first experiment, the permeability decreased from 0.72 $\mathrm{mbar} / \mathrm{LMH}$, to $0.47 \mathrm{mbar} / \mathrm{LMH}$, while after the $4^{\text {th }}$ physical cleaning, and for the second experiment, these permeabilities corresponded to $0.75 \mathrm{mbar} / \mathrm{LMH}$ and 0.44 mbar/LMH, respectively. This indicates that, despite the physical cleanings and the backwash at the beginning of the $J_{t}$ determinations, the fouling was being accumulated on the membrane pores, indicating that physical cleaning alone is not enough to ensure the recovery of membrane permeability. Moreover, the decreasing permeabilities have probably influenced the threshold flux results. If the membrane 
was completely restored with physical cleanings, the threshold fluxes after the first experiment would probably be higher than the current threshold fluxes measured. Since the physical protocols were not sufficient for restoring the initial membrane permeability, the fouling was classified as irreversible [45]. However, the chemical cleaning with $\mathrm{NaClO}$ and citric acid dissolution before the second train was able to efficiently restore the permeability to the value at the beginning of the experiments, proving this to be an important procedure in promoting the membrane filterability, at least in the short-term. The use of these reagents, however, require caution, and long term assessment is desirable in order to better understand the behavior in the long term [46]. The NaClO does not cause severe damages to the structure of the PVDF membranes, but its long-term application may cause changes to the membrane surface and to its hydrophilicity characteristics, as verified by Wang et al. [47]. On the other hand, the mildness of the citric acid associated with its rinsability for inorganic foulants [48], actually stimulates its application either alone or coupled with oxidizing reagents [30].

\subsection{Long-term continuous municipal wastewater concentration process by direct membrane filtration}

\subsubsection{Wastewater concentration process}

A continuous experiment for urban wastewater up-concentration was carried out with intermittent gas scouring. The operating conditions for the continuous experiment are presented in Table 2. 
Table 2 - Operating conditions for the continuous process of wastewater concentration

\begin{tabular}{cc}
\hline Feed flow $(L / h)$ & 10 \\
Permeate flux $\left(L / m^{2} . h\right)$ & 12.7 \\
Volume of concentrate $(\mathrm{L})$ & $4^{*}$ \\
Gas scouring velocity $(\mathrm{m} / \mathrm{h})$ & $19-97$ \\
\hline days on average &
\end{tabular}

*Every 4 days on average

The operation proved to be efficient for the concentration process, ensuring the production of a stable permeate completely free of suspended particles. Moreover, the total COD in the effluent has been reduced by $85 \%$ allowing only the soluble matter to remain in the permeate stream. Jin et al. [49] also showed an average COD removal of $94 \%$ with a physicochemical-based enhanced membrane coagulation reactor (E-MCR) during a continuous operation process. Zhao et al. [28] found similar COD reduction, around 90\%. In both cases, however, previous coagulation processes were performed.

The process has been shown as feasible, reaching high concentrations of organic matter, fitting with the desirable concentrations for a subsequent anaerobic digestion. The concentrated solids were periodically purged with an average volume estimated as $4 \mathrm{~L}$ each 4 days. This stream presented concentrations in the range of 19,000-54,000 mg/L COD, with an average 30,720 \pm 8,058 mg/L, therefore being characterized as a high loaded. The concentration of this stream of solids is variable, depending on the flow and the frequency of the purges performed. The obtained concentrations of TS were between 17.68 and $32.29 \mathrm{~g} / \mathrm{L}$, with an average $24.02 \pm$ $4.13 \mathrm{~g} / \mathrm{L}$, and VS were between 12.42 and $23.02 \mathrm{~g} / \mathrm{L}$, with an average $16.65 \pm 2.79$ $\mathrm{g} / \mathrm{L}$. The resulted TS content are of the same order as those used in the experiments for the threshold flux. Nevertheless, due to the membrane tank design and the frequency of purges performed, these values are only reached in the lower section and not in the filtration zone, in keeping with the objective. 
The membrane tank height allows the filtration design to be separated in two zones, the upper section, where the membrane is located, and the lower section or concentration section, where the particulate matter is thus concentrated. Because of this design, the TSS concentration remained at around $0.47 \mathrm{~g} / \mathrm{L}$ in the filtration section (sp 2), which implies a remarkable stratification with respect to the concentration section. The effect of the gas scouring and the air lift have also contributed to this behavior, and hence to a lower rate of membrane fouling. Samples from the sampling points sp 3 and sp 4 (see Fig. 1) were periodically collected in order to measure the TS concentrations and then, to control the height of the concentrate volume. Along the experiment, the TS concentrations have varied between 4 and 32 gTS/L for the sp 4, and between 2 and 7 gTS/L for the sp 3, which indicates that the majority of solids are sedimented at the lower section of the membrane tank (32.9 L between sp1 and sp 5) with higher concentration values in the first $16 \mathrm{~L}$ comprised between the sp 4 and the sp 5 .

High concentrate streams have also been achieved by other authors. Jin et al. [23], working with cycles consisting of 12-min permeation followed by 3-min relaxation at doses of $30 \mathrm{mg} / \mathrm{L}$ polyaluminum chloride (PAC) over a 295-h continuous concentration period, reached a COD concentration around $16,000 \mathrm{mg} / \mathrm{L}$. Nevertheless, the COD concentration reached in the present work is even higher, being achieved every four days when the purge is carried out, and without the addition of coagulants. Gong et al. [42], also adding coagulants together with controlled filtration (10 min permeation and 2 min membrane relaxation) and air backflushing ( 25 s on during the relaxation period) in continuous operation, were able to reach a COD concentration of around $23,000 \mathrm{mg} / \mathrm{L}$ when the amounts of entering and discharging organics were balanced. Jin et al. [49], on the other hand, also with an enhanced membrane coagulation reactor (E-MCR) in a long-term process with air- 
backflushing (200 kPa of pressure during $30 \mathrm{~s}$ each 5 min30s) and $1 \mathrm{~d}$ of concentrate retention time, reported a COD concentration of $9,700 \mathrm{mg} / \mathrm{L}$ with $94 \%$ of recovery.

\subsubsection{COD/TS balance}

In order to avoid oxidation, and to check for the possible loss of organic matter, the experiment was carried out closed off from the atmosphere. Initially, the composition of the gas chamber was essentially air, nevertheless, as time went on, the oxygen was consumed, and the predominant gas became nitrogen. The gas within the membrane tank was analyzed throughout the experiment, resulting in an average final composition of $95 \%$ of $\mathrm{N}_{2}, 4 \%$ of $\mathrm{O}_{2}, 2 \%$ of $\mathrm{CO}_{2}, 0.7 \%$ of $\mathrm{CH}_{4}$ and $0.1 \%$ of $\mathrm{H}_{2} \mathrm{~S}$ which indicates a negligible conversion rate of COD through anaerobic digestion. Otherwise, the carbon dioxide and methane proportion were expected to be higher.

The mass balance was carried out over the entire period of operation by the integration of the individual data collected during the experiment. Regarding the total COD content, $16 \%$ of the soluble COD was drained out of the membrane tank in the permeate stream, and the purged streams contained about $54 \%$ of the total COD in the feed. Thus, the theoretical losses of matter corresponded to $30 \%$ of the total feed COD. These differences in the mass balance are probably due to the loading variation in the wastewater feed throughout the day, that actually influenced the precision of the mass balance. Besides, after the experiment, the membrane tank was opened and a cake layer attached to the membrane module was verified, but not recovered. The recovery of organic matter could help to better close the COD mass balance since, as can be seen from the gas composition, there has been practically no anaerobic degradation of the concentrated organic matter.

This process permitted the recovery of a dense stream of concentrated wastewater, and a permeate free of any particles, with a minor loss of matter. These 
losses, however, have been frequently reported by other researchers. Jin et al. [23], using both coagulation and intermittent aeration, with a normalized air flow rate of $0.12 \mathrm{~m}^{3} / \mathrm{h}$ with intermittent air blowing for 3 min every $15 \mathrm{~min}$, reported an influent organic matter recovery of nearly $70 \%$, with a mineralized COD representing about $19 \%$ of the total COD mass. In the present work, the loss of COD was higher, at around $30 \%$ of the inlet COD, not including, however, the cake layer at the end of the experiment. Kimura et al. [48] working with two sequentially connected filtration tanks in which hollow-fiber MF membrane modules were immersed, set with a total HRT of about $3.1 \mathrm{~h}$ and without aeration, have indicated from a COD mass balance that about $75 \%$ of the organic matter in the raw municipal wastewater was recovered. Organic matter losses may depend on the amount of air supplied to maintain the membrane operation. The increases in airflow rate increase the oxidation of organic matter and consequently decrease the methane recovery. Also, Gong et al. [42], working with different powdered active carbon concentrations, showed around 72.1 and $75.7 \%$ of organic recovery in a concentrated form, 14.2 and $12.8 \%$ of discharged organics in the effluent, and 13.7 and $11.5 \%$ comprised by losses.

Biomethane potential assays performed using the concentrated solids have pointed to an average specific methane production of $250 \mathrm{mLCH}_{4} / \mathrm{gVSS}_{\text {fed, }}$ which is a reasonable result for that kind of primary wastewater [50]. A simplified energy balance has been outlined in order to estimate the benefits of the gas scouring at intermittent regime and the benefits of a carbon harvest by the DMF from the primary municipal wastewater. Intermittent gas scouring, essentially nitrogen gas $\left(\mathrm{N}_{2}\right)$ at 97 $\mathrm{m} / \mathrm{h}$ (40 s each $3.5 \mathrm{~min}$ ) operating in a closed circuit at $20^{\circ} \mathrm{C}$, was considered for the compressor requirements. The membrane tank headspace was considered as having $30 \mathrm{mbar}(0.03 \mathrm{~atm})$ of positive pressure, a column of $1.0 \mathrm{~m}$ (0.1 atm) of wastewater was considered for the gas scouring and an overall $1.5 \mathrm{~m}$ of head loss was used for 
the estimation. And, for the permeate pumping, it was assumed that the system was controlled with 400 mbar of filtration pressure by pushing a filtration flux of 12.7 LMH of permeate in a cyclic filtration process regime consisting of 7 min filtration, $5 \mathrm{~s}$ pause, $30 \mathrm{~s}$ backwash, and $5 \mathrm{~s}$ pause. For the methane generation, it is assumed that at least $95 \%$ of the VSS from a wastewater contained an average $210 \mathrm{mgVSS} / \mathrm{L}$ would be retained within the membrane tank as concentrated stream, and this stream would be conveyed to the anaerobic digestion process at $250 \mathrm{mLCH}_{4} / \mathrm{gVSS}_{\mathrm{fed}}$ as specific methane production.

Results showed energy consumption rates (per cubic meter of permeate) of $0.14 \mathrm{kWh} / \mathrm{m}^{3}$ for the gas scouring and $0.01 \mathrm{kWh} / \mathrm{m}^{3}$ for the permeate pumping and, $0.19 \mathrm{kWh} / \mathrm{m}^{3}$ for the power production (considering $889 \mathrm{~kJ} / \mathrm{molCH}_{4}$ heat power and electrical efficiency of 35\%). Therefore, a surplus of $0.04 \mathrm{kWh} / \mathrm{m}^{3}$ of the energy produced is reached in the DMF process and could cover minor requirements for the operation. The intermittent regime for the gas scouring means an important practice for the energy savings. The assumed cycle for the compressor means that it is operating during $16 \%$ of a continuous time regime, otherwise the energy consumption would raise to $0.89 \mathrm{kWh} / \mathrm{m}^{3}$ in continuous mode. Besides, there are much room to improve the overall process and some considerations would significantly play in favor of the system. For instance, by reducing the air scouring velocity $(80 \mathrm{~m} / \mathrm{h})$, reducing head losses $(1 \mathrm{~m})$ and considering a higher specific methane production (300 $\mathrm{mLCH}_{4} / \mathrm{gVSS}_{\text {fed }}$ ) a positive $0.13 \mathrm{kWh} / \mathrm{m}^{3}$ is theoretically achievable.

It is worth noting that depending on the wastewater strength, the permeate stream would carry an important fraction of dissolved organic matter and the anaerobic treatment, at a low temperature (an Upflow Anaerobic Sludge Blanket reactor, for example) could be an interesting approach for extra energy production. 
Kimura et al. [48] proposes a low-energy consuming process such as a packed biological filter for treatment of the permeate. Recent studies have reported the feasibility of positive net electrical energy production through membrane-based systems. By coupling the pre-concentration of municipal wastewater through direct membrane filtration with further anaerobic processes for the conversion of organic matter into biogas, Gong et al. [42] reported a positive balance of between 0.050 and $0.029 \mathrm{kWh} / \mathrm{m}^{3}$, whereas jin et al. [49] indicated a net energy production of at least $0.0315 \mathrm{kWh} / \mathrm{m}^{3}$. Both authors also drew attention to the need to optimize processes which would certainly lead to more sustainable results in the systems.

\subsubsection{TMP behavior}

The continuous experiments have been operated with a constant feed flow rate of $10 \mathrm{~L} / \mathrm{h}$ and with intermittent gas scouring ( $40 \mathrm{~s}$ on and 3.5 minutes off) with coarse bubbles from the bottom of the membrane module. Throughout the process, it was necessary to increase the superficial gas velocity as the TMP increased, in order to control membrane fouling. Thus, the influence of gas scouring on the wastewater concentration was assessed. The TMP behavior for the filtration is presented in Fig. 3 by the blue square dots.

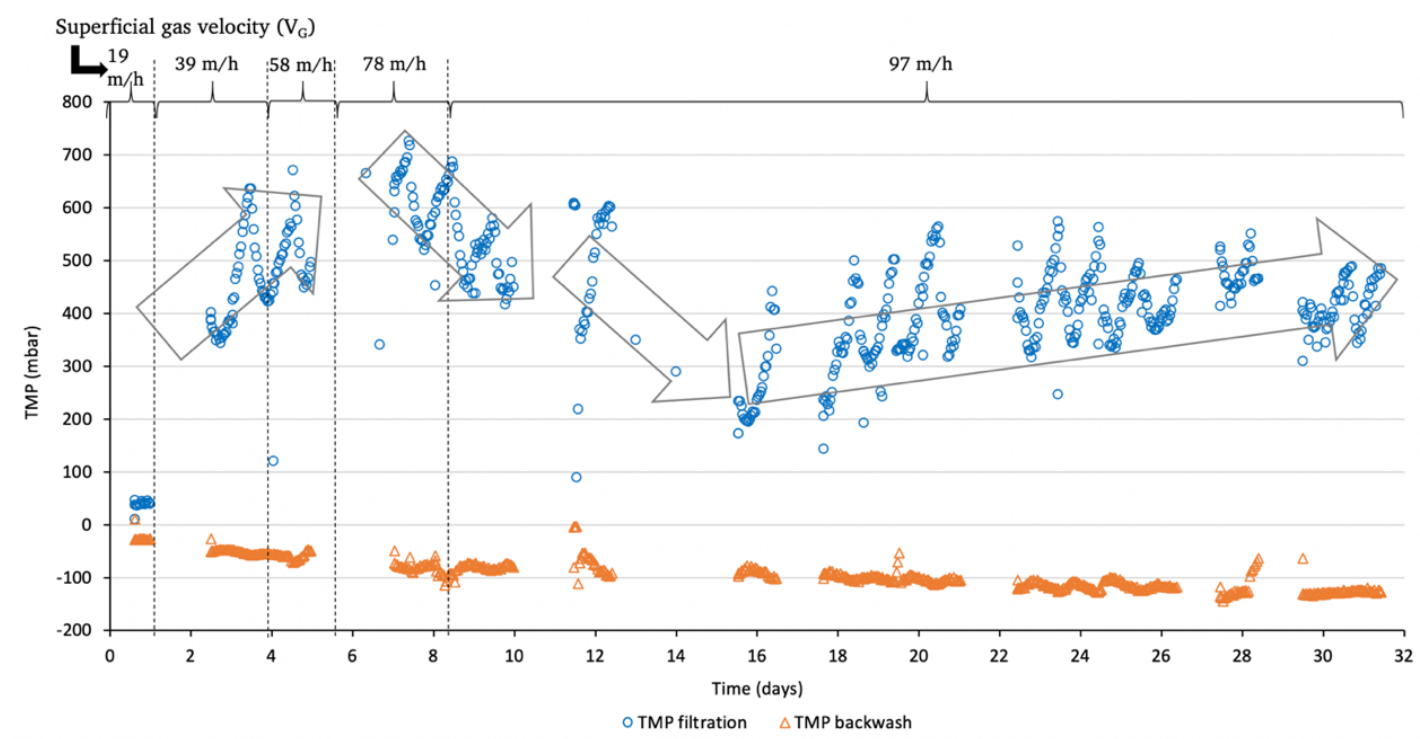

Figure 3 - TMP evolution during the continuous concentration process 
The TMPs have gradually decreased to values near to $400 \mathrm{mbar}$ when a superficial gas velocity of $78 \mathrm{~m} / \mathrm{h}$ was applied. Later, however, a new gas velocity increase to $97 \mathrm{~m} / \mathrm{h}$ was needed in order to keep the membrane operating for longer in a range between 300 and 500 mbar of TMP. Since the feed and filtration flows were kept constant during the experiment, membrane fouling and the possible formation of cake on the membrane surface were responsible for the TMP increase. However, this fouling seems to be reversible, since the increase in gas scouring up to $97 \mathrm{~m} / \mathrm{h}$ allows the membrane to operate for a longer period. Periodic purging from the lower section of the tank has also contributed to the maintenance of the membrane operability. These purges prevent high solid concentrations in the filtration section which, otherwise, would prompt the fouling formation. The strategy of increasing the superficial gas scouring has enabled the concentration process in the long-term. Other authors have addressed long-term experiments by applying different antifouling methods. This is the case of Horstmeyer et al. [51], who showed the importance of active carbon as a strategy to reduce membrane fouling, while Gong et al. [42] demonstrated that the addition of powdered active carbon is an interesting approach for the reduction of membrane fouling due to the stronger flock formation.

The TMP of the backwash, indicated by the graph with orange triangular dots, decreased only slightly throughout the experiment. This may suggest that the pore block effect occurred to a small extent, and the resistance was mainly due to the reversible fouling. The range of the TMPs was similar to those reported by other authors working with direct sewage filtration. For example, Gong et al. [42], reported increasing TMPs up to a maximum of 700 mbar, which was the stable TMP over many days of continuous operation, while the filtration fluxes decreased from about 10 $\mathrm{L} / \mathrm{m}^{2} . \mathrm{h}$ to nearly $5 \mathrm{~L} / \mathrm{m}^{2} . \mathrm{h}$. 


\subsubsection{Effect of the gas scouring and the permeate backwash combined}

Another noteworthy point is the combined effect of the gas scouring and permeate backwash. Fig. 3 was constructed by taking the average TMP of 500 mbar measured pressure points (recorded each $3 \mathrm{~s}$ by the Picolog ${ }^{\circledR}$ program) in order to make it easier to appreciate of the filtration tendencies. When it comes to individual measures of pressure, the filtration pressures follow a different behavior pattern. Fig. 4 illustrates an excerpt from a graph plotted by the Picolog program with individual measures of pressures in two hours of operation.

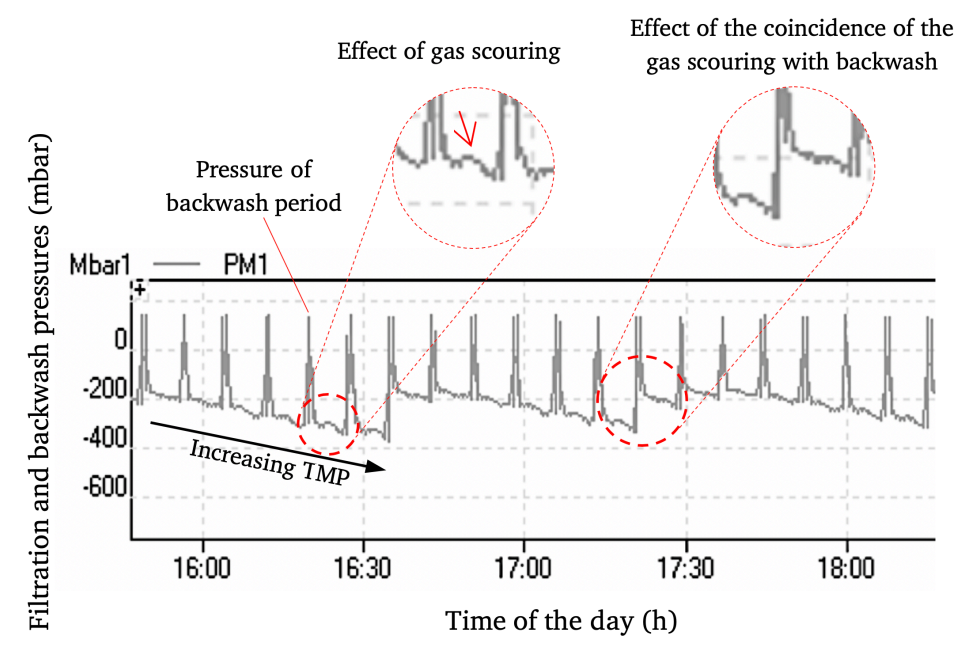

Figure 4 - Filtration pattern graph with the effect of backwash and gas scouring

According to the graph, during the 7 minutes of the filtration stage, the pressures were continuously dropping (increasing TMP) even with the periodical permeate backwash and gas scouring effect. The backwash and gas scouring timer controls only coincide every 45 minutes, approximately. When operating separately, these two antifouling strategies act by delaying the formation of the cake layer over the membrane, not impeding, however, the subsequently increase in TMP. However, as they currently coincide every $45 \mathrm{~min}$, the filtration pressures rapidly decrease, probably as a response to the loose effect over the cake layer due to the backwash, and the dragging of solids caused by the gas scouring, which leaves the filtration section free of most of the particles. Likewise, the gas scouring may also contribute 
to make the cake layer over the membrane surface thinner, and, consequently, decrease the filtration resistance. Once the backwash and gas scouring coincide, the filtration pressures start dropping again until the next time they coincide. As a result, this strategy enables a more stable process for the wastewater up-concentration, while guaranteeing a better controlled pressure increase. This behavior should be studied further in order for a precise conclusion to be drawn regarding the effects of these combined strategies.

\section{Conclusions}

The DMF is a robust technology for concentrating the particulate matter from municipal wastewater, favoring the harvest of the organic matter content by subsequent anaerobic treatment. Experiments determined that this operation is feasible for the concentration of organic matters up to $18 \mathrm{~g}$ TSS/L, for moderate gas scouring velocities and permeate fluxes with sustainable threshold fluxes. Also, the membrane fouling control by gas scouring over the membrane fibers can increase the threshold flux by $300 \%$ in a $33 \mathrm{~g}$ TSS/L wastewater filtration, with gas scouring velocities increasing from 0 to $30 \mathrm{~m} / \mathrm{h}$. A long-term experiment with intermittent gas scouring and permeate backwash resulted in a viable process, reaching high solid concentration streams of between 19,000 and $54,000 \mathrm{mg} / \mathrm{L}$ of COD, potentiating the energy self-sufficiency of the process through methane production.

\section{Acknowledgments}

This work was supported by the Regional Government of Castilla y León and the EUFEDER (CLU 2017-09 and UIC 071). The authors also would like to thank the CNPq National Council for the Scientific and Technological Development - Brazil, for the PhD scholarship of Thiago A. Nascimento [234006/2014-5]. 


\section{References}

[1] D.J. Batstone, T. Hülsen, C.M. Mehta, J. Keller, Platforms for energy and nutrient recovery from domestic wastewater: A review, Chemosphere. $140 \quad$ (2015) 2-11. doi:10.1016/j.chemosphere.2014.10.021.

[2] Y. Ye, H.H. Ngo, W. Guo, S.W. Chang, D.D. Nguyen, X. Zhang, J. Zhang, S. Liang, Nutrient recovery from wastewater: From technology to economy, Bioresour. Technol. Reports. (2020) 100425. doi:10.1016/j.biteb.2020.100425.

[3] Y. He, Y. Zhu, J. Chen, M. Huang, P. Wang, G. Wang, W. Zou, G. Zhou, Assessment of energy consumption of municipal wastewater treatment plants in China, J. Clean. Prod. 228 (2019) 399-404. doi:10.1016/j.jclepro.2019.04.320.

[4] D. Panepinto, S. Fiore, M. Zappone, G. Genon, L. Meucci, Evaluation of the energy efficiency of a large wastewater treatment plant in Italy, Appl. Energy. 161 (2016) 404-411. doi:10.1016/j.apenergy.2015.10.027.

[5] W.Q. Guo, S.S. Yang, W.S. Xiang, X.J. Wang, N.Q. Ren, Minimization of excess sludge production by in-situ activated sludge treatment processes - A comprehensive review, Biotechnol. Adv. 31 (2013) 1386-1396. doi:10.1016/j.biotechadv.2013.06.003.

[6] J. Frijns, J. Hofman, M. Nederlof, The potential of (waste)water as energy carrier, Energy Convers. Manag. 65 (2013) 357-363. doi:10.1016/j.enconman.2012.08.023.

[7] J.M. Garrido, M. Fdz-Polanco, F. Fdz-Polanco, Working with energy and mass balances: A conceptual framework to understand the limits of municipal wastewater treatment, Water Sci. Technol. 67 (2013) 2294-2301. doi:10.2166/wst.2013.124.

[8] G. Sarpong, V.G. Gude, B.S. Magbanua, Energy autarky of small scale wastewater treatment plants by enhanced carbon capture and codigestion - A quantitative analysis, Energy Convers. Manag. 199 (2019) 111999. doi:10.1016/j.enconman.2019.111999.

[9] B.C. Huang, W.W. Li, X. Wang, Y. Lu, H.Q. Yu, Customizing anaerobic digestion-coupled processes for energy-positive and sustainable treatment of municipal wastewater, Renew. Sustain. Energy Rev. 110 (2019) 132-142. doi:10.1016/j.rser.2019.04.064.

[10] X. Song, W. Luo, F.I. Hai, W.E. Price, W. Guo, H.H. Ngo, L.D. Nghiem, Resource recovery from wastewater by anaerobic membrane bioreactors: Opportunities and challenges, Bioresour. Technol. 270 (2018) 669-677. doi:10.1016/J.BIORTECH.2018.09.001.

[11] C. Shin, J. Bae, Current status of the pilot-scale anaerobic membrane bioreactor treatments of domestic wastewaters: A critical review, Bioresour. Technol. 247 (2018) 1038-1046. doi:10.1016/J.BIORTECH.2017.09.002.

[12] T.A. Nascimento, F. Fdz-polanco, M. Peña, T.A. Nascimento, F. Fdz-polanco, M. Peña, Membrane-Based Technologies for the Up- Concentration of Municipal Wastewater : A Review of Pretreatment Intensification, Sep. Purif. Rev. 00 (2018) 1-19. doi:10.1080/15422119.2018.1481089.

[13] H. Guven, R.K. Dereli, H. Ozgun, M.E. Ersahin, I. Ozturk, Towards sustainable and energy efficient municipal wastewater treatment by up-concentration of organics, Prog. Energy Combust. Sci. 70 (2019) 145-168. doi:10.1016/j.pecs.2018.10.002.

[14] S. Hube, M. Eskafi, K.F. Hrafnkelsdóttir, B. Bjarnadóttir, M.Á. Bjarnadóttir, S. Axelsdóttir, B. Wu, 
Direct membrane filtration for wastewater treatment and resource recovery: A review, Sci. Total Environ. 710 (2020) 136375. doi:10.1016/j.scitotenv.2019.136375.

[15] J. Jimenez, M. Miller, C. Bott, S. Murthy, H. De Clippeleir, B. Wett, High-rate activated sludge system for carbon management - Evaluation of crucial process mechanisms and design parameters, Water Res. 87 (2015) 476-482. doi:10.1016/j.watres.2015.07.032.

[16] A. Rahman, H. De Clippeleir, W. Thomas, J.A. Jimenez, B. Wett, A. Al-Omari, S. Murthy, R. Riffat, C. Bott, A-stage and high-rate contact-stabilization performance comparison for carbon and nutrient redirection from high-strength municipal wastewater, Chem. Eng. J. 357 (2019) 737 749. doi:10.1016/j.cej.2018.09.206.

[17] H. Zhuang, J. Guan, S.Y. Leu, Y. Wang, H. Wang, Carbon footprint analysis of chemical enhanced primary treatment and sludge incineration for sewage treatment in Hong Kong, J. Clean. Prod. 272 (2020) 122630. doi:10.1016/j.jclepro.2020.122630.

[18] H. Gong, X. Wang, M. Zheng, Z. Jin, K. Wang, Direct sewage filtration for concentration of organic matters by dynamic membrane, Water Sci. Technol. 70 (2014) 1434-1440. doi:10.2166/wst.2014.379.

[19] J. Xiong, S. Yu, Y. Hu, Y. Yang, X.C. Wang, Applying a dynamic membrane filtration (DMF)process for domestic wastewater preconcentration: Organics recovery and bioenergy production potential analysis, Sci. Total Environ. $680 \quad$ (2019) 35-43. doi:10.1016/j.scitotenv.2019.05.080.

[20] A.J. Ansari, F.I. Hai, W. Guo, H.H. Ngo, W.E. Price, L.D. Nghiem, Factors governing the preconcentration of wastewater using forward osmosis for subsequent resource recovery, Sci. Total Environ. 566-567 (2016) 559-566. doi:10.1016/j.scitotenv.2016.05.139.

[21] X. Bao, Q. Wu, J. Tian, W. Shi, W. Wang, Z. Zhang, R. Zhang, B. Zhang, Y. Guo, S. Shu, F. Cui, Fouling mechanism of forward osmosis membrane in domestic wastewater concentration: Role of substrate structures, Chem. Eng. J. $370 \quad$ (2019) 262-273. doi:10.1016/j.cej.2019.03.174.

[22] G. Mezohegyi, M.R. Bilad, I.F.J. Vankelecom, Direct sewage up-concentration by submerged aerated and vibrated membranes, Bioresour. Technol. 118 (2012) 1-7. doi:10.1016/j.biortech.2012.05.022.

[23] Z. Jin, H. Gong, H. Temmink, H. Nie, J. Wu, J. Zuo, K. Wang, Efficient sewage pre-concentration with combined coagulation microfiltration for organic matter recovery, Chem. Eng. J. 292 (2016) 130-138. doi:10.1016/j.cej.2016.02.024.

[24] S.K. Lateef, B.Z. Soh, K. Kimura, Direct membrane filtration of municipal wastewater with chemically enhanced backwash for recovery of organic matter, Bioresour. Technol. 150 (2013) 149-155. doi:10.1016/j.biortech.2013.09.111.

[25] T.A. Nascimento, F.R. Mejía, F. Fdz-Polanco, M. Peña, Improvement of municipal wastewater pretreatment by direct membrane filtration, Environ. Technol. 38 (2017) 2562-2572. doi:10.1080/09593330.2016.1271017.

[26] B. Wu, Membrane-based technology in greywater reclamation: A review, Sci. Total Environ. 656 (2019) 184-200. doi:10.1016/j.scitotenv.2018.11.347.

[27] H. Gong, Z. Jin, H. Xu, Q. Wang, J. Zuo, J. Wu, K. Wang, Redesigning C and N mass flows for 
energy-neutral wastewater treatment by coagulation adsorption enhanced membrane (CAEM)based pre-concentration process, Chem. Eng. J. 342 (2018) 304-309. doi:10.1016/j.cej.2018.02.086.

[28] Y. xia Zhao, P. Li, R. hong Li, X. yan Li, Direct filtration for the treatment of the coagulated domestic sewage using flat-sheet ceramic membranes, Chemosphere. 223 (2019) 383-390. doi:10.1016/j.chemosphere.2019.02.055.

[29] T. Hey, N. Bajraktari, Å. Davidsson, J. Vogel, H.T. Madsen, C. Hélix-Nielsen, J. la C. Jansen, K. Jönsson, Evaluation of direct membrane filtration and direct forward osmosis as concepts for compact and energy-positive municipal wastewater treatment, Environ. Technol. 39 (2017) 264-276. doi:10.1080/09593330.2017.1298677.

[30] Y. xia Zhao, P. Li, R. hong Li, X. yan Li, Characterization and mitigation of the fouling of flatsheet ceramic membranes for direct filtration of the coagulated domestic wastewater, J. Hazard. Mater. 385 (2020). doi:10.1016/j.jhazmat.2019.121557.

[31] R.W. Field, D. Wu, J.A. Howell, B.B. Gupta, Critical flux concept for microfiltration fouling, J. Memb. Sci. 100 (1995) 259-272. doi:10.1016/0376-7388(94)00265-Z.

[32] P. Le Clech, B. Jefferson, I.S. Chang, S.J. Judd, Critical flux determination by the flux-step method in a submerged membrane bioreactor, J. Memb. Sci. 227 (2003) 81-93. doi:10.1016/j.memsci.2003.07.021.

[33] R.W. Field, G.K. Pearce, Critical, sustainable and threshold fluxes for membrane filtration with water industry applications, Adv. Colloid Interface Sci. 164 (2011) 38-44. doi:10.1016/j.cis.2010.12.008.

[34] P. Bacchin, P. Aimar, R.W. Field, Critical and sustainable fluxes: Theory, experiments and applications, J. Memb. Sci. 281 (2006) 42-69. doi:10.1016/j.memsci.2006.04.014.

[35] M. Bagheri, S.A. Mirbagheri, Critical review of fouling mitigation strategies in membrane bioreactors treating water and wastewater, Bioresour. Technol. 258 (2018) 318-334. doi:10.1016/j.biortech.2018.03.026.

[36] T. Fujioka, L.D. Nghiem, Fouling control of a ceramic microfiltration membrane for direct sewer mining by backwashing with ozonated water, Sep. Purif. Technol. 142 (2015) 268-273. doi:10.1016/j.seppur.2014.12.049.

[37] H. Gong, Z. Jin, Q. Wang, J. Zuo, J. Wu, K. Wang, Effects of adsorbent cake layer on membrane fouling during hybrid coagulation/adsorption microfiltration for sewage organic recovery, Chem. Eng. J. 317 (2017) 751-757. doi:10.1016/j.cej.2017.02.122.

[38] APHA, Standard Methods for the Examination of Water and Wastewater, 22nd ed., American Public Health Association, Washington D.C., 2012.

[39] C. Rouquié, L. Dahdouh, J. Ricci, C. Wisniewski, M. Delalonde, Immersed membranes configuration for the microfiltration of fruit-based suspensions, Sep. Purif. Technol. 216 (2019) 25-33. doi:10.1016/j.seppur.2019.01.062.

[40] M. Chai, Y. Ye, V. Chen, Separation and concentration of milk proteins with a submerged membrane vibrational system, J. Memb. Sci. $524 \quad$ (2017) 305-314. doi:10.1016/j.memsci.2016.11.043.

[41] A. Kola, Y. Ye, A. Ho, P. Le-Clech, V. Chen, Application of low frequency transverse vibration on 
fouling limitation in submerged hollow fibre membranes, J. Memb. Sci. 409-410 (2012) 5465. doi:10.1016/j.memsci.2012.03.017.

[42] H. Gong, Z. Jin, H. Xu, Q. Yuan, J. Zuo, J. Wu, K. Wang, Enhanced membrane-based preconcentration improves wastewater organic matter recovery: Pilot-scale performance and membrane fouling, J. Clean. Prod. 206 (2019) 307-314. doi:10.1016/j.jclepro.2018.09.209.

[43] A. Bottino, G. Capannelli, A. Comite, R. Mangano, Critical flux in submerged membrane bioreactors for municipal wastewater treatment, Desalination. 245 (2009) 748-753. doi:10.1016/j.desal.2009.02.047.

[44] B. Verrecht, S. Judd, G. Guglielmi, C. Brepols, J.W. Mulder, An aeration energy model for an immersed membrane bioreactor, Water Res. 42 (2008) 4761-4770. doi:10.1016/j.watres.2008.09.013.

[45] Z. Wang, J. Ma, C.Y. Tang, K. Kimura, Q. Wang, X. Han, Membrane cleaning in membrane bioreactors: A review, J. Memb. Sci. 468 (2014) 276-307. doi:10.1016/j.memsci.2014.05.060.

[46] C. Regula, E. Carretier, Y. Wyart, G. Gésan-Guiziou, A. Vincent, D. Boudot, P. Moulin, Chemical cleaning/disinfection and ageing of organic UF membranes: A review, Water Res. 56 (2014) 325-365. doi:10.1016/j.watres.2014.02.050.

[47] P. Wang, Z. Wang, Z. Wu, Q. Zhou, D. Yang, Effect of hypochlorite cleaning on the physiochemical characteristics of polyvinylidene fluoride membranes, Chem. Eng. J. 162 (2010) 1050-1056. doi:10.1016/j.cej.2010.07.019.

[48] K. Kimura, D. Honoki, T. Sato, Effective physical cleaning and adequate membrane flux for direct membrane filtration (DMF) of municipal wastewater: Up-concentration of organic matter for efficient energy recovery, Sep. Purif. Technol. 181 (2017) 37-43. doi:10.1016/j.seppur.2017.03.005.

[49] Z. Jin, F. Meng, H. Gong, C. Wang, K. Wang, Improved low-carbon-consuming fouling control in long-term membrane-based sewage pre-concentration: The role of enhanced coagulation process and air backflushing in sustainable sewage treatment, J. Memb. Sci. 529 (2017) 252262. doi:http://dx.doi.org/10.1016/j.memsci.2017.02.009.

[50] E. Elbeshbishy, G. Nakhla, H. Hafez, Biochemical methane potential (BMP) of food waste and primary sludge: Influence of inoculum pre-incubation and inoculum source, Bioresour. Technol. 110 (2012) 18-25. doi:10.1016/j.biortech.2012.01.025.

[51] N. Horstmeyer, C. Thies, T. Lippert, J.E. Drewes, A hydraulically optimized fluidized bed UF membrane reactor (FB-UF-MR) for direct treatment of raw municipal wastewater to enable water reclamation with integrated energy recovery, Sep. Purif. Technol. 235 (2020). doi:10.1016/j.seppur.2019.116165. 



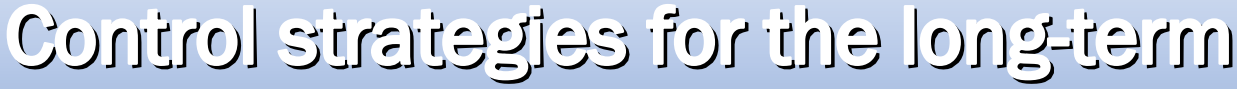

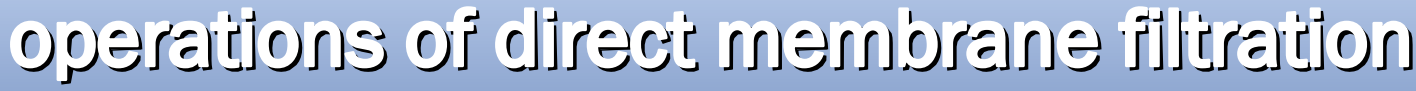 of nunnjojpal wastewajter}

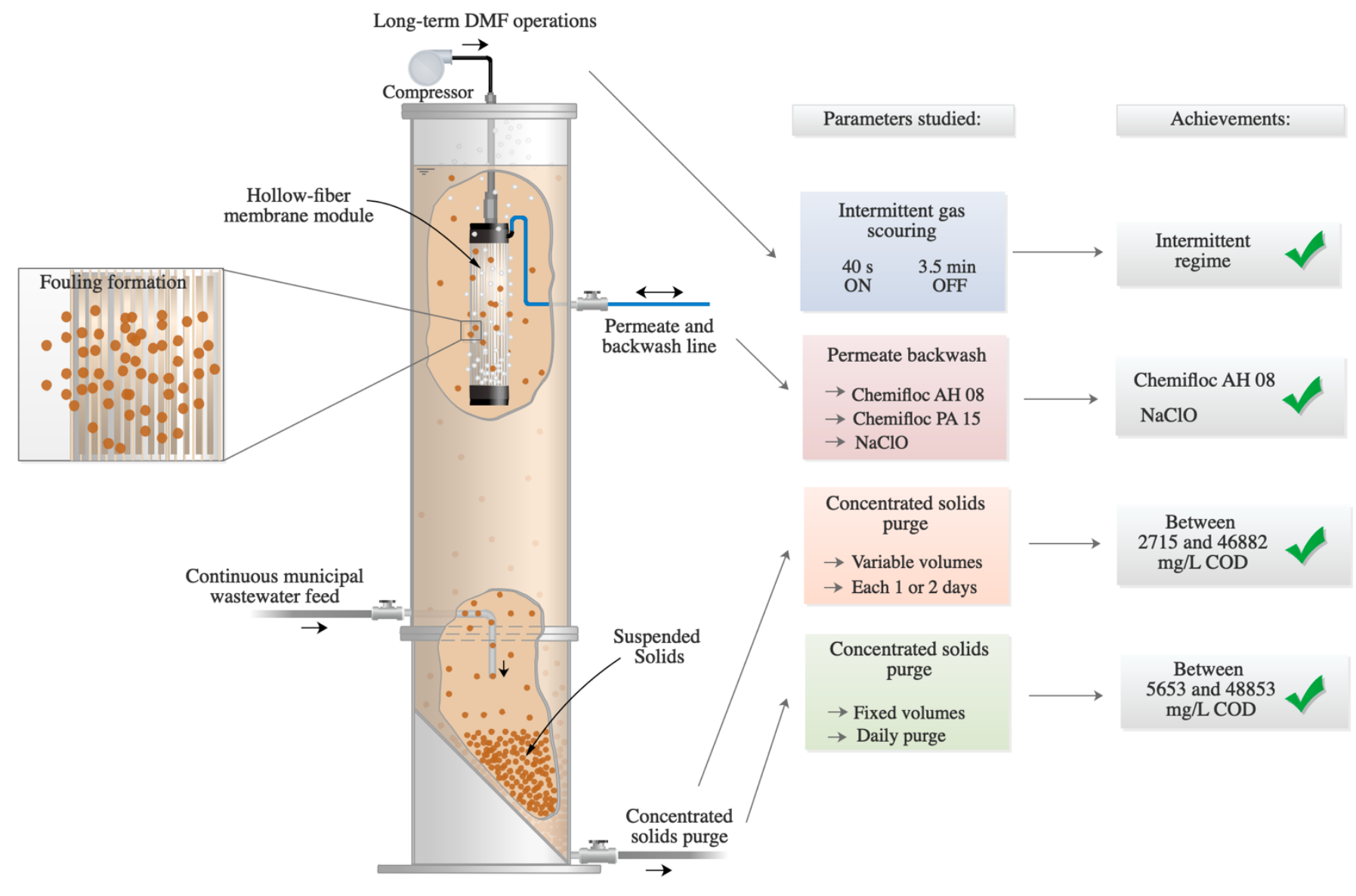





\title{
Control strategies for the long-term operation of direct membrane filtration of municipal wastewater
}

\author{
Thiago A. Nascimentoa*, Mar Peña Mirandaa \\ a Department of Chemical Engineering and Environmental Technology, University of Valladolid \\ a Institute of Sustainable Processes, University of Valladolid, Dr. Mergelina s/n, 47011 Valladolid, \\ Spain \\ *Corresponding author. Tel.: +34 983423166. E-mail address: thiagoantonio.do- \\ nascimento@alumnos.uva.es
}

\section{Abstract}

Original experiments of wastewater ultrafiltration have been carried out following the concept of the so-called direct membrane filtration (DMF). These experiments aimed to assess different strategies for fouling control and the effects to the concentrated solids recovering. Results showed that a $97 \mathrm{~m} / \mathrm{h}$ of gas scouring velocity $\left(\mathrm{V}_{\mathrm{G}}\right)$ at intermittent regime associated with enhanced permeate backwash with low to medium concentration of anionic polyelectrolyte (Chemifloc AH 08) can maintain the transmembrane pressures (TMPs) under 400 mbar and guarantee the recovery of high concentrated solids streams. The concentrated solids purge, which was varying from daily to each 2.5 days, was another fundamental variable studied. With variable recovered volumes, the daily solids purge allows for the recovering of high solids concentration, between 2715 and $46882 \mathrm{mg} / \mathrm{L}$ of chemical oxygen demand (COD) and between 1070 and $42450 \mathrm{mg} / \mathrm{L}$ of total solids (TS), without jeopardizing the membrane filtration. These purges of high solids concentrations were reached along with the operations in association with intermittent $V_{G}$ around $13 \mathrm{~m} / \mathrm{h}$ and combined or not with chemical enhanced backwash. Sodium hypochlorite $(\mathrm{NaClO})$ dissolutions have also been tested for both the fouling removing and impact over the anaerobic digestion of the concentrated solids. Punctual cleaning in place with $\mathrm{NaClO}$ dissolutions with 500 and 1000 ppm resulted effective for keeping the TMPs under 400 mbar. In addition, the biomethane potential assays performed with the recovered solids showed that these dissolutions had no significant effect over the specific methane production which yielded up $311 \mathrm{mLCH}_{4} / \mathrm{gVS}_{\text {subs. }}$ 
Keywords: primary wastewater concentration, organic matter recovery, anaerobic digestion, ultrafiltration membrane.

\section{Introduction}

Water scarcity is already a reality for many countries, and the negative perspective for usable water availability is a rising concern over the globe. Simultaneously, a wide range of practices for the rationing, recycling, and reuse of water is the scope of many stakeholders in the water cycle. In this chain, wastewater treatment plants (WWTPs) are of great relevance to address a high-quality effluent while allowing for high-value products recovery from the wastewater stream, such as nutrients and organic matter in biogas form. Furthermore, the increasing interest in the biorefinery concept has led the WWTP to a new approach from an energy consumer to an energy producer [1] and source of bioproducts [2,3].

In this sense, the direct use of membranes for the wastewater treatment, through the so-called process direct membrane filtration (DMF), is being proved workable for wastewater treatment because of their capacity to guarantee a permeate free of suspended solids and to generate a concentrated stream of raw organic matter [4]. This loaded and small stream of particulate solids can be conveyed to a mesophilic anaerobic digestion for biogas production, hence potentiating carbon recovery, minimizing facilities and saving power supply. The major stream of permeate would only contain soluble matter and could be used for nutrients recovery or conveyed directly for irrigation, depending on the nutrients load, soluble organic content, and other refined parameters established by the legislation [5].

This is the main approach of the DMF, and it has been increasingly discussed for municipal wastewater treatment. In the last years, short and long term and lab 
and pilot-scale experiments have given some clues of the DMF potential as a process for the up-concentration of raw municipal wastewater. Moreover, researchers have reported concentrate streams with up to $23,000 \mathrm{mg} / \mathrm{L}$ of chemical oxygen demand (COD) [6] and the application of different membrane configurations and different physical-chemical methods as an antifouling strategy $[7,8]$. Yet, the major drawback remains in the membrane fouling inherent to the process. Whether in submerged or side stream configuration, the membrane fibers are submitted to incrustation provided by organic, inorganic or biological fouling which drops the permeate production through gel formation, adsorption, deposition, pore blockage, or cake formation [9].

In the last years, some unconventional methods like photocatalysis, ultrasound, electrofiltration, membrane vibration, and rotating membrane have been investigated for preventing fouling formation onto the membrane surface during the processes of direct filtration of wastewater [10-14]. Although prominent, these techniques are in the infancy stage and economical and technical aspects still needed to be addressed for a feasible long-term industrial operation. Regarding the currently applied techniques on an industrial scale, some reviews have been prepared and they reported that the so-called conventional strategies for fouling mitigation over low-pressure membranes are still the most applied and the ones that provide better results in the wastewater treatment besides being associated with relatively low operating cost [15-18].

These conventional techniques are used against the reversible or irreversible fouling which affects the critical, sustainable, and threshold fluxes on a wastewater filtration process which, in turn, are directly related to economic factors [19]. The reversible fouling is caused by colloids and particles without affinity to the membrane surface and therefore are easily removed by physical cleanings, like permeate 
backwash, relaxation, and gas/air scouring $[20,21]$. In contrast, the irreversible fouling has a more severe impact on the permeate production since the particles are deposited within the membrane pores throughout hydrophobic/hydrophilic and electrostatic interactions with membrane structure, therefore, physical cleaning methods are not capable of restoring the membrane permeability [22]. For that reason, chemical cleanings are usually performed with acids, bases, oxidants, a combination of these reagents and other commercial chemicals in order to dissolve, displace or chemically modify the foulants [9].

The literature reported the conventional methods against the fouling formation mainly for membrane bioreactors (MBR) since this technology is way mature and it is already found in many installations. But studies are still needed for the direct membrane filtration in order to assess cleaning frequency, the concentration of chemicals for the chemical cleanings, and the consequences of their application over the membrane structure. Besides, it is important to consider the impact of the antifouling strategies over the anaerobic digestion of the concentrated solids and over the permeate productivity. Moreover, regardless of the chosen techniques, a combined physical-chemical cleaning seems to be the most appropriate approach by providing maintenance and recovery of the membrane permeability [15], even though when it comes to the long-term operation of direct membrane filtration of municipal wastewater, reports are still fairly scarce.

With these considerations in mind, this work aims to assess the performance of the municipal wastewater up-concentration process by the DMF, and the membrane behavior under different approaches for fouling minimization at long-term operations on a pilot scale. A series of experiments set with combined antifouling methods such as permeate backwash and intermittent gas scouring, in line polyelectrolyte dosage combined with intermittent gas scouring, and periodical 
cleaning in place combined with daily purge, were assessed in order to provide useful criteria for the DMF operation, and their implication for the methane yield through the biodegradation of the concentrated solids.

\section{Materials and Methods}

\subsection{General membrane tank setup}

The setup used throughout the performed experiments is represented in Fig. 1. The pilot plant was composed of a vertical polypropylene tank, $1.76 \mathrm{~m}$ in height and $0.34 \mathrm{~m}$ in diameter, with effective volume of $126 \mathrm{~L}$. This tank, defined as membrane tank, is divided into two main sections: a filtration section (in the upper part) considered the section on the membrane surrounds, where the wastewater filtration takes place, and a concentrate section, (in the lower part) between the sampling points sp 1 and sp 5, where the heavier particulate matter is deposited after coming from the feeding wastewater and after being separated through the filtration in the upper section. 


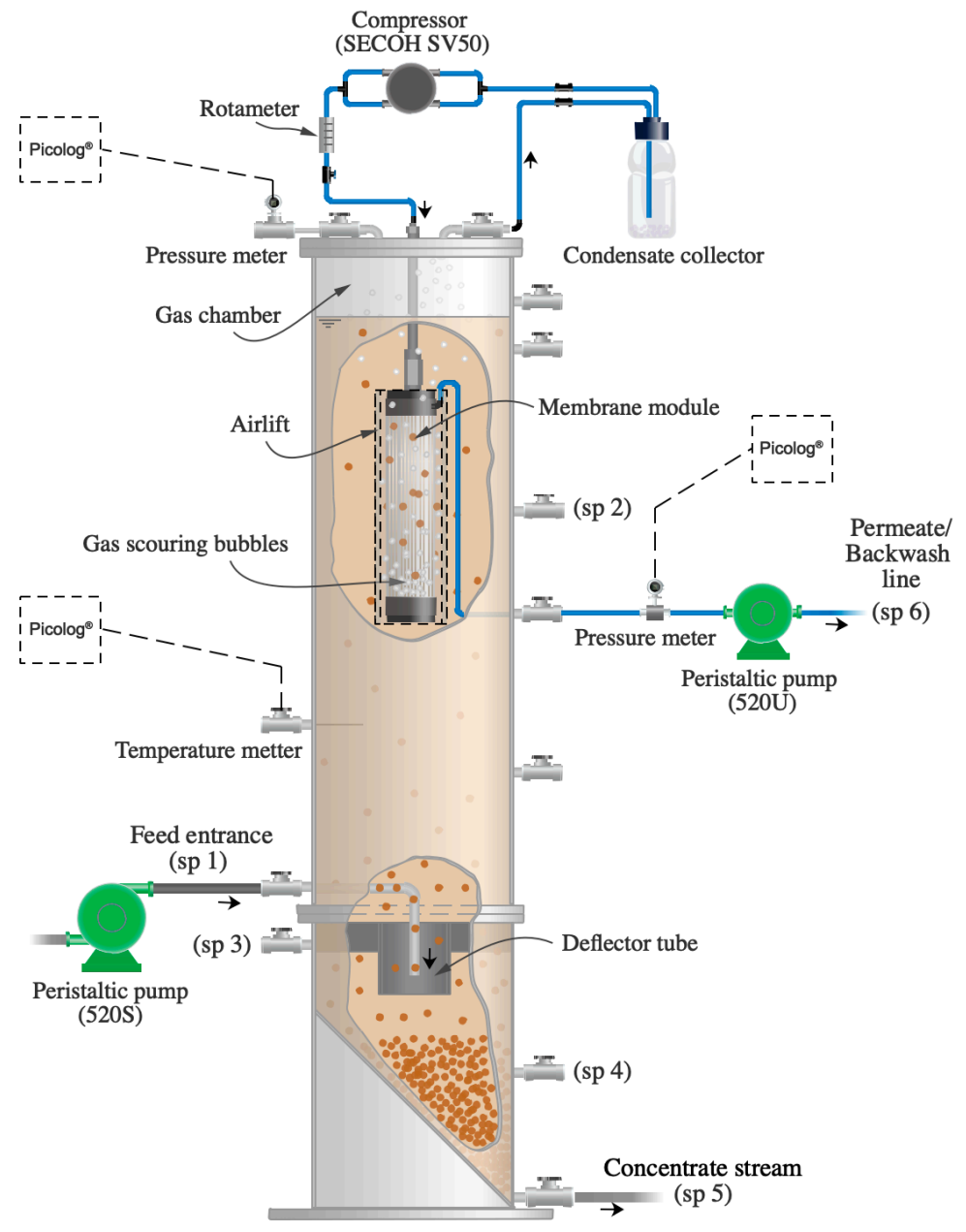

Figure 1 - Schematic representation of the pilot plant setup

The feed wastewater is conducted through a centrical tube into the bottom of the membrane tank. This centrical tube works as a deflector by hindering the larger particles from rising out of the feed wastewater and into the filtration section. A pipe is used, which reaches the center and is directed downwards. The sedimentation zone comprises a total volume of $32.9 \mathrm{~L}$.

For all the operations, the filtration cycle was configured as 0.5 min backwash, $5 \mathrm{~s}$ pause, 7 min filtration and $5 \mathrm{~s}$ pause again, which means that the time for the production of filtrate corresponded to $91.3 \%$ of the total filtration cycle.

The membrane module used in the experiments is made of polyvinylidene fluoride (PVDF), hollow fiber, and outside-in configured (ZeeWeed-10 Zenon), with a mean pore size of $0.04 \mu \mathrm{m}$ and filtration area of $0.93 \mathrm{~m}^{2}$. At the bottom of the module 
there is a diffuser of coarse bubbles that provides the intermittent gas scouring (40 $\mathrm{s}$ of operation followed by a pause of $3.5 \mathrm{~min}$ ) with the same temperature and composition to the membrane fibers in all experiments. The gas scouring flux is provided by a compressor (SECOH, SV50, Barcelona, ES) and the velocity of scouring is controlled by a rotameter. The superficial gas velocities $\left(V_{G}\right)\left(m^{3} / h\right)$ applied intermittently along the experiments were calculated, taking into account either the transversal area of an airlift, which is a cylindrical protector made of PVC placed surrounding the membrane module with $0.015 \mathrm{~m}^{2}$ of sectional area and $0.69 \mathrm{~m}$ in height, or the transversal area of the membrane tank with $0.09 \mathrm{~m}^{2}$. The gas line was close to the atmosphere so as to avoid aerobic carbon oxidation. At the beginning of the experiments the headspace is composed essentially of air, but as time went on the oxygen fraction is consumed and the nitrogen gas becomes predominantly the gas resultant. A condensate collector with silica gel was also used to retain most of the humidity from the recirculated gas.

The membrane tank has several sampling points (sp), which were used for sampling through the experiments: the feed entrance to the membrane tank (sp 1), the filtration section ( $s p 2$ ), the control of the concentrate section ( $s p 3, s p 4$, and $s p$ 5) and, the permeate line (sp 6). Peristaltic pumps were used for the feed (Watson Marlon, 520S, Madrid, ES) and filtration/backwash lines (Watson Marlon, 520U, Madrid, ES). The plant was equipped with pressure transmitters (Endress + Hauser, PMC 131, -1 to 1 bar, Valladolid, ES) in the permeate/backwash line and in the headspace of the membrane tank. The Picolog Technology Ltd. data acquisition system was used to monitor and store the data regarding temperature, headspace pressure, and filtration pressures. As illustrated in Fig. 1, the membrane module is placed within the upper section of the membrane tank. 


\subsection{Design for the continuous operations of DMF}

Four experiments (S1, S2, S3 and S4) were carried out with different objectives focusing on assessing the efficiency of antifouling strategies. As strategies for fouling control, intermittent gas scouring, permeate backwash, and purge of concentrated solids have been adopted in common throughout the experiments. Some specific method and additional practices, however, were set according to the target objectives in each operation. After each operation, the membrane tank has been emptied and cleaned. The membrane module has been physically cleaned with tap water jet and soft sponge, and then twice chemically cleaned with $2 \mathrm{~h}$ soaked in 1000 ppm $\mathrm{NaClO}$ dissolution under continuous agitation, followed by another $2 \mathrm{~h}$ soaked in $1 \%$ citric acid under continuous agitation.

Table 1 summarizes the main operating conditions for each one experiment.

Table 1 - Operating conditions of the different continuous experiments for municipal wastewater upconcentration by DMF

\begin{tabular}{ccccc}
\hline Parameter & S1 & S2 & S3 & S4 \\
\hline Feed flow $(L / h)$ & 10 & 10 & 12 & 12 \\
Permeate flux $\left(L / \mathrm{m}^{2} . h\right)$ & 12.7 & 12.7 & 15.2 & 15.2 \\
Air scouring section $\left(\mathrm{m}^{2}\right)$ & 0.015 & 0.09 & 0.09 & 009 \\
Polyelectrolyte & Chemifloc AH-08 & & & \\
Oxidant & Chemifloc PA-15 & & & \\
Acid & $\mathrm{NaClO}$ & & $\mathrm{NaClO}$ & $\mathrm{NaClO}$ \\
Purge frequency (days) & Citric acid & & & \\
Purge volume $(L)$ & 2.5 & $1-2$ & 1 & 1 \\
Time of operation (days) & 3 & $3-26$ & $4-6$ & 4 \\
\hline
\end{tabular}

* Time of operation with each concentration of $\mathrm{NaClO}$ added.

The fouling control in the experiment S1 was assessed through the addition of commercials polyelectrolytes, sodium hypochlorite $(\mathrm{NaClO})$, and citric acid, together with variable velocities of gas scouring applied at intermittent regime within the airlift. The polyelectrolytes Chemifloc AH-08 (low anionic flocculant, high- 
molecular-weight, supplied by Chemipol ${ }^{\circledR}$ ) and Chemifloc PA-15 (organic coagulantflocculant polyamine-based, very low-molecular-weight, supplied by Chemipol ${ }^{\circledR}$ ) were chosen among five other polyelectrolytes based on the results of a previous jar test for separating the particulate matter from municipal wastewater. These chosen polyelectrolytes have been added through the permeate backwash with two different concentrations each one, $1.5 \mathrm{~g} / \mathrm{L}$ and $15 \mathrm{~g} / \mathrm{L}$ and each dosage was performed in distinct days. The Chemifloc $\mathrm{AH}-08$ has been firstly added in three dosages and then the Chemifloc PA-15 has been dosed twice. The operation was never stopped during this experiment.

The experiments S2, S3, and S4, on another hand, have in common the same $V_{G}$ of $13 \mathrm{~m} / \mathrm{h}$ applied along with the entire operations on intermittent regime, and they were set without the airlift. Also, the filtration fluxes for S1 and S2 were set as 12.7 L/m².h, meanwhile, a $15.2 \mathrm{~L} / \mathrm{m}^{2} . \mathrm{h}$ was adopted for $\mathrm{S} 3$ and $\mathrm{S} 4$.

The experiment $\mathbf{S 2}$ has as aim to assess the effect of the solids purges over the membrane filtration. In the first 15 days of operation, the purge was performed daily and then it was performed every two days on average with the recovering of variables volumes of concentrated solids, according to the reached concentrations.

The experiment S3 also focused on the effect of long-term solids purge, but with fixed volumes of purge and the effect of the enhanced permeate backwash with NaClO over the TMP control.

For the experiment $\mathrm{S} 4$, different concentrations of $\mathrm{NaClO}$ were tested for the fouling control and the effect of the $\mathrm{NaClO}$ addition over the organic matter has also been monitored throughout biomethane potential (BMP) assays performed with the concentrated solids purged. 


\subsection{Characteristics of the feed wastewater}

The experiments were performed in Santovenia de Pisuerga WWTP (SPWWTP). This plant receives both industrial and urban wastewaters from 4500 inhabitants, approximately. The plant primary treatment is composed of coarse and fine screens followed by a rectangular aerated grit chamber and the biological treatment has an oxidation ditch as the main treatment. The raw wastewater was collected from the downstream section of the grit chamber stage of the SPWWTP and was continuously fed to the pilot plant. Table 2 summarizes the average characteristics of the wastewater during each of the experiments performed.

Table 2 - Characteristics of feed wastewater for each carried out continuous experiment.

\begin{tabular}{ccccc}
\hline & S1 & S2 & S3 & S4 \\
\hline$t C O D(m g / L)$ & $202( \pm 114)^{a}$ & $1885( \pm 1656)$ & $329( \pm 221)$ & $322( \pm 166)$ \\
SCOD $(\mathrm{mg} / \mathrm{L})$ & $33( \pm 9)$ & $59( \pm 40)$ & $51( \pm 36)$ & $53( \pm 39)$ \\
TS $(\mathrm{mg} / \mathrm{L})$ & $1544( \pm 240)$ & $1880( \pm 1335)$ & $771( \pm 194)$ & $794( \pm 171)$ \\
VS $(\mathrm{mg} / \mathrm{L})$ & $490( \pm 120)$ & $1121( \pm 928)$ & $326( \pm 134)$ & $314( \pm 85)$ \\
TSS $(\mathrm{mg} / \mathrm{L})$ & $156( \pm 100)$ & $1469( \pm 1383)$ & $207( \pm 150)$ & $188( \pm 133)$ \\
VSS $(\mathrm{mg} / \mathrm{L})$ & $150( \pm 100)$ & $1111( \pm 1003)$ & $184( \pm 118)$ & $134( \pm 80)$ \\
\hline
\end{tabular}

a The data in parenthesis are the standard deviations

The wastewater streams presented a wide range of load variations during the period in which the experiments were carried out. During the experiment S2, the primary treatment of the Santovenia WWTP presented a malfunction in grit chamber which was reflected as higher loads compared to the other average concentrations of wastewater. Nevertheless, the wastewater was taken as an opportunity for evaluating the membrane behavior at higher concentrations of solids.

Samples from the feed (sp 1) and from the other sampling points ( $s p 2, \mathrm{sp} 3$, sp 4, and sp 5) were periodically collected in order to determine total COD, soluble 
COD, total solids (TS), volatile solids (VS), total suspended solids (TSS) and volatile suspended solids (VSS) according to the Standard Methods for the Examination of Water and Wastewater [23].

\subsection{Biochemical methane potential assays}

Biomethane potential (BMP) assays were being performed along the operations S1, S2 and S4 for determining whether the organic content from wastewater is harmed or not by the additions of chemicals. The samples of concentrated solids for the BMPs were collected from the sample point $\mathrm{sp} 5$. An anaerobic inoculum used was obtained from a pilot sludge digester and preincubated for two days $\left(35.1 \pm 0.3^{\circ} \mathrm{C}\right)$ to minimize its residual biodegradable organic matter content. The tests were performed in triplicate and a blank test without substrate was included. Serum bottles with a volume of $160 \mathrm{~mL}$ were used in the BMP tests, with a reaction volume of $80 \mathrm{~mL}$. The inoculum ratio $(\mathrm{S} / \mathrm{X})$ was 0.4 gVS $_{\text {subs }} / g S_{\text {inoc. }}$ The bottles were sealed, using rubber septa and aluminum crimp caps, and then gassed with helium gas, and subjected to continuous agitation in an orbital shaker. The biogas production was daily monitored with a pressure meter (ifm electronics, PI 1696, -124 to 2500 mbar, Valladolid, ES) and samples of biogas were

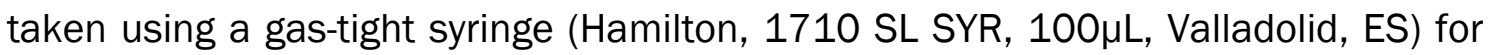
determining the biogas composition. Biogas composition was then analyzed using a gas chromatograph (Varian CP-3800, Palo Alto, CA, USA) coupled with a thermal conductivity detector and equipped with a CP-Molsieve $5 \mathrm{~A}(15 \mathrm{~m} \times 0.53 \mathrm{~mm} \times 15 \mu \mathrm{m})$ and CP-Pora BOND Q (25 m x $0.53 \mathrm{~mm} \times 15 \mu \mathrm{m})$ columns.

The specific methane yield (SMY), $\mathrm{mL} \mathrm{CH}_{4} / \mathrm{gVS}_{\text {subs }}$ was calculated by dividing the net methane production associated with the substrate by the volatile solids from the feed substrate in the serum bottles at the beginning of the test. 


\section{Results and Discussion}

\subsection{Effect of polyelectrolytes addition as a strategy for fouling control (Experiment} S1)

The experiment $\mathrm{S} 1$ has lasted 44 days in continuous mode (with 1 stopping from around day 11 to day 13 for a technical repair in the feeding line) as stated in Fig. 2.

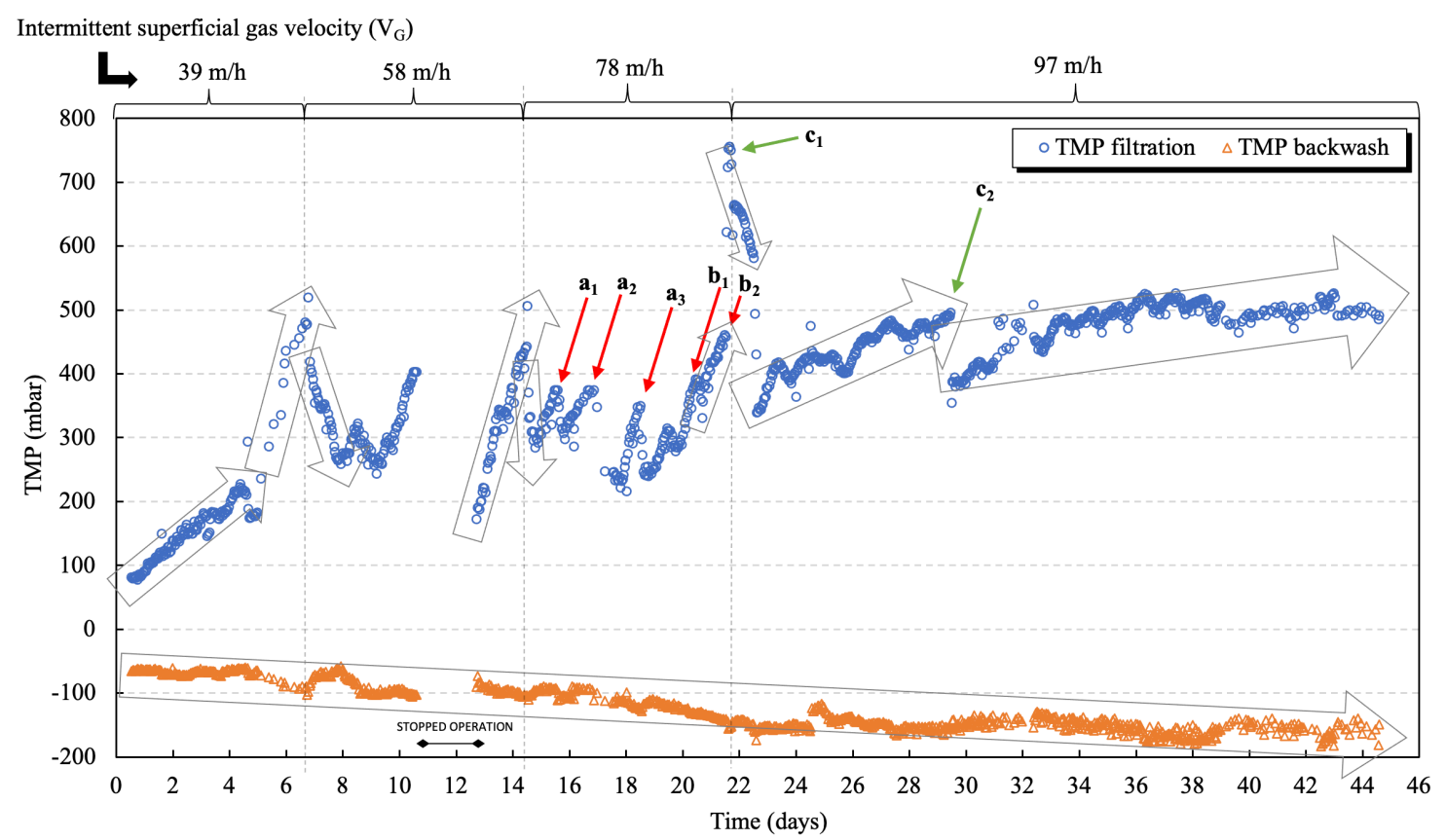

Figure 2 - TMP evolution during the long-term operation with the additions of $2 \mathrm{~L}$ of Chemifloc AH-08 (a1: $1.5 \mathrm{~g} / \mathrm{L} ; \mathrm{a}_{2}: 15 \mathrm{~g} / \mathrm{L}$ and $\left.\mathrm{a}_{3}: 15 \mathrm{~g} / \mathrm{L}\right), 2 \mathrm{~L}$ of Chemifloc PA 15 (b1: $\left.1.5 \mathrm{~g} / \mathrm{L} ; \mathrm{b}_{2}: 15 \mathrm{~g} / \mathrm{L}\right)$ and $5 \mathrm{~L}$ of $\mathrm{NaClO}$ ( $c_{1}: 1000$ ppm and $c_{2}: 1000$ ppm) combined with intermittent gas scouring (40 s of operation followed by a pause of $3.5 \mathrm{~min}$ ) and periodic purge of concentrated solids (each 2.5 days).

The operation started with a permeate flux of $12.7 \mathrm{~L} / \mathrm{m}^{2} \mathrm{~h}$, which is practically constant during the operation, and $39 \mathrm{~m} / \mathrm{h}$ of superficial gas velocity at intermittent regime. The first 7 days are marked by the increasing TMP of filtration because of rapid fouling formation. Apparently, the gas scouring velocity was not high enough to outperform the formation of solids cake layer onto the membrane surface, therefore, the superficial gas velocity was increased to $58 \mathrm{~m} / \mathrm{h}$, at intermittent regime, in order to maintain the TMPs of filtration around 400 mbar of pressure. This pressure was 
defined for guaranteeing the filtration productivity and for preventing physical damages to the membrane module.

As evidenced by the graphic, at the moment a higher gas velocity is applied the TMPs started dropping, however, the rate of fouling layer formation started increasing again as noticed between days 7 and 10 and between days 12 and 14 . Therefore, another approach was taken by adding polyelectrolytes to the wastewater within the membrane tank through the permeate line, as performed by other researchers [24] and with the intention of mainly limiting the solids content close to the membrane fibers. Concomitantly, intermittent gas scouring and purge of concentrated solids were also performed. The gas scouring velocity was firstly increased to $78 \mathrm{~m} / \mathrm{h}$, and in order to keep the values of TMP controlled, the synthetic polyelectrolyte Chemifloc AH 08, was added at day 15 with $1.5 \mathrm{~g} / \mathrm{L}$ of concentration. A $2 \mathrm{~L}$ of the prepared polyelectrolyte dissolution was directed injected to the membrane module $\left(a_{1}\right)$ through the permeate backwash with the same operating filtration flux, $12.7 \mathrm{~L} / \mathrm{m}^{2}$.h. The volume of $2 \mathrm{~L}$ was calculated by considering the diameter and length of the membrane fibers plus a safety factor to ensure that enough volume of dissolution would fill all the fibers and, therefore, promote a uniform distribution. Within the membrane tank, the dissolution was expected to be diluted in the $126 \mathrm{~L}$ of wastewater volume, resulting in a concentration of $\approx 24 \mathrm{ppm}$.

The pressure data show a slight decrease of TMPs, although not sustained along the time, which justified two other doses of polyelectrolyte dissolution $\left(\mathrm{a}_{2}\right.$ and a3). These doses of $2 \mathrm{~L}$ each one of them were prepared with a higher concentration of $15 \mathrm{~g} / \mathrm{L}(\approx 240 \mathrm{ppm}$ in the membrane tank), which resulted in the dropping of TMPs to near 200 mbar of pressures at days 16 and 18 . The effectiveness of the addition of the anionic polyelectrolyte can be explained by the complementary effect of flocculation over the microfloc particles in the feeding wastewater. The feeding 
wastewater is composed of fresh wastewater plus the recirculated supernatant that comes from the sludge dewatering line of the SPWWTP. For the sludge dewatering, the SPWWTP has as practice the addition of a synthetic polyelectrolyte, Chemifloc $\mathrm{CH}$ 35 (strong cationic polymer), with high molecular weight. This cationic polyelectrolyte acts by neutralizing the negative charges of the suspended particles in the wastewater, allowing for the formation of microfloc particles [25]. In turn, the anionic polyelectrolyte addition (Chemifloc $\mathrm{AH} 08$ ) within the membrane tank has prompt the formation of large floc agglomerates by some mechanisms involved when a highmolecular-weight polyelectrolyte is added, like polymer bridging [26-28].

It is important to notice that, despite the primary microfloc formation provided by the Chemifloc $\mathrm{CH} 35$, apparently, the membrane pores were not affected, probably because of the smaller membrane pores size. Otherwise, a strong irreversible fouling would make impossible the continuity of the filtration. On another hand, after dosing Chemifloc $\mathrm{AH}-08$, the heavy flocs formed have sedimented into the lower section of the membrane tank, reducing, as a result, the fouling formation over the membrane fibers, here verified as a decreasing of TMP of filtration at the days 15,17 , and 18 , as depicted in Fig. 2.

In order to analyze the effect of another polymer, the Chemifloc PA 15 was then tested as an option against the fouling formation. Two doses ( $2 \mathrm{~L}$ each) of this coagulant were tested with two concentrations, a $1.5 \mathrm{~g} / \mathrm{L}\left(\mathrm{b}_{1}\right)$ and a $15 \mathrm{~g} / \mathrm{L}\left(\mathrm{b}_{2}\right)$, nevertheless, both doses presented a negative effect over the filtration with a rising of TMPs to over 700 mbar for the higher concentration of coagulant, likely due to the membrane pore blockage resulted from the increasing of fine particles in the wastewater or obstructions in the permeate line prompted by the coagulant dosage. It is important to note that the applied dosages of coagulants may have led the particles to the so-called restabilization, the phenomenon by which the negative 
colloidal particles are turned into positively charged because of the excess of the cationic polymer. The reversal of the particle charge reduces the efficiency of the coagulation causing re-dispersal of the agglomerates into fine particles $[27,29]$.

In order to reverse the fouling resulted from the coagulant addition, a strong cleaning in place was performed with the increasing of the intermittent gas scouring to $97 \mathrm{~m} / \mathrm{h}$ of velocity and with a chemical enhanced backwash with $5 \mathrm{~L}$ of a 1000 ppm dissolution of $\mathrm{NaClO}\left(\mathrm{c}_{1}\right)(\approx 40 \mathrm{ppm}$ in the membrane tank), added through the backwash line at the same operating filtration flux of $12.7 \mathrm{~L} / \mathrm{m}^{2}$.h. A second cleaning in place has been made with $5 \mathrm{~L}$ of a $1000 \mathrm{ppm} \mathrm{NaClO}$ dissolution followed by $1 \mathrm{~L}$ of $1 \%$ dissolution of citric acid ( $\approx 79 \mathrm{ppm}$ in the membrane tank) $\left(\mathrm{c}_{2}\right)$. In both cleanings, the TMPs have decreased to around 300-400 and increased to 500 mbar only after a few days of operation. Indeed, the cleaning in place with $\mathrm{NaClO}$ followed by citric acid with the applied concentrations is very popular and has been reported as an efficient combination for the maintenance of membrane filtration processes [30]. While oxidants such as $\mathrm{NaClO}$ remove organic and biological contaminants, the acid cleaning aims to dissolute inorganic fouling.

The anionic polyelectrolyte addition has induced a favorable effect of solids agglutination which, as a consequence, allowed the operation of the membrane filtration under lower pressures. Therefore, the chemical cleaning in place through the enhanced permeate backwash is of major importance to recover the membrane permeability in the long-term. When properly addressed with enough gas scouring velocity, the punctual chemical cleaning allows the filtration to operate during a reasonable number of days without interventions other than the regular permeate backwash. Besides, the costs of $\mathrm{NaClO}$ and citric acid are way more attractive than the polyelectrolytes, although the membrane process design may define whether to use a settling aid. 
In order to assess the stability of the process in recovering high solids concentrations during a long-term operation, the concentrated solids at the bottom of the membrane tank were being periodically purged, according to the frequency in Table 1. The range of concentrations of solids in the purges and in the filtration section, and the average concentrations in the permeate streams during the experiment $\mathrm{S} 1$ is presented in Table 3.

Table 3 - Results obtained from the municipal wastewater concentration processes S1, S2, S3, and S4

\begin{tabular}{|c|c|c|c|}
\hline & Purge & Filtration section & Permeate \\
\hline \multicolumn{4}{|l|}{ Experiment S1 } \\
\hline $\operatorname{COD}(m g / L)$ & $1940-23641^{a}$ & $51-319$ & $38( \pm 14)^{b}$ \\
\hline $\mathrm{TS}(m g / L)$ & $2780-20360$ & $1130-1807$ & $1463( \pm 193)$ \\
\hline $\mathrm{VS}(m g / L)$ & $1220-15240$ & $290-702$ & $380( \pm 62)$ \\
\hline TSS (mg/L) & & $30-184$ & 0 \\
\hline VSS (mg/L) & & $30-236$ & 0 \\
\hline \multicolumn{4}{|l|}{ Experiment S2 } \\
\hline $\operatorname{COD}(m g / L)$ & $2715-46882$ & $90-642$ & $40( \pm 23)$ \\
\hline $\mathrm{TS}(m g / L)$ & $1070-42450$ & $479-1910$ & $578( \pm 146)$ \\
\hline $\mathrm{VS}(m g / L)$ & $590-30830$ & $194-459$ & $169( \pm 35)$ \\
\hline TSS (mg/L) & & $70-1440$ & 0 \\
\hline VSS (mg/L) & & $70-252$ & 0 \\
\hline \multicolumn{4}{|l|}{ Experiment S3 } \\
\hline $\operatorname{COD}(m g / L)$ & $5653-48853$ & $275-682$ & $50( \pm 20)$ \\
\hline $\mathrm{TS}(m g / L)$ & $4367-21670$ & $704-1000$ & $571( \pm 72)$ \\
\hline $\operatorname{VS}(m g / L)$ & $4160-16260$ & $300-567$ & $210( \pm 134)$ \\
\hline TSS (mg/L) & & $20-412$ & 0 \\
\hline VSS (mg/L) & & $20-380$ & 0 \\
\hline \multicolumn{4}{|l|}{ Experiment S4 } \\
\hline $\operatorname{COD}(m g / L)$ & $2362-25197$ & $70-299$ & $37( \pm 24)$ \\
\hline $\mathrm{TS}(\mathrm{mg} / \mathrm{L})$ & $7010-20850$ & $580-810$ & $578( \pm 46)$ \\
\hline $\mathrm{VS}(m g / L)$ & $4150-11150$ & $190-320$ & $152( \pm 26)$ \\
\hline TSS (mg/L) & & $60-160$ & 0 \\
\hline VSS (mg/L) & & $60-140$ & 0 \\
\hline
\end{tabular}

a Interval of concentrations.

$\mathrm{b}$ The data in parenthesis are the standard deviation. 
According to the obtained data, the sedimented solids have been up concentrated to feasible values for the anaerobic digestion [31]. Indeed, most of the concentrations was situated above $10000 \mathrm{mg} / \mathrm{L}$ in terms of COD and TS. It indicates that the purge frequency appeared as a reasonable period for accomplishing the desired solids concentration.

\subsection{Effect of variable volumes of solids purged as a strategy for fouling control (experiment S2)}

This experiment assessed the importance of the variable volumes of solids purged against the membrane fouling by operating with high strength wastewater. The operating conditions are established in Table 1. The operation lasted 39 days with the TMPs of filtration having been kept between 100 and 400 mbar during most of the time, as indicated by the round blue dots in Fig. 3, therefore preserving the membrane module from physical damages.

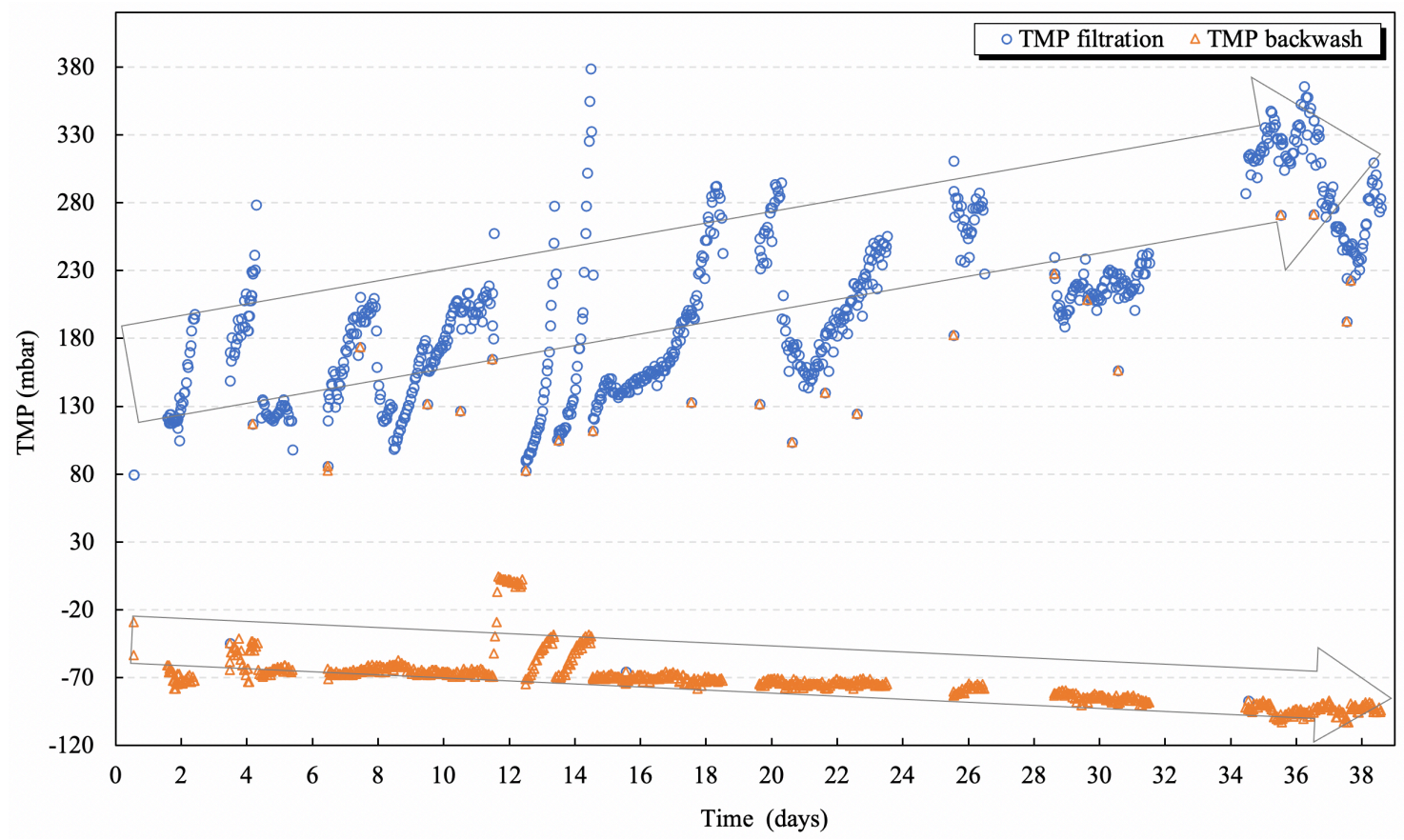

Figure 3 - TMP evolution during the long-term operation for assessing the effect of variable volumes of solids purged (between 3 and $26 \mathrm{~L}$ ) as strategy for fouling control combined with intermittent gas scouring ( $13 \mathrm{~m} / \mathrm{h}$ for $40 \mathrm{~s}$ of operation followed by a pause of $3.5 \mathrm{~min}$ ). 
The set regime of concentrated solids purge allowed the operation to be maintained in a long term without a major increase in the TMPs of filtration, otherwise, due to the high concentration of the feed, the TMPs would have surpassed the 400 mbar. The volume of the purges varied according to the accumulated solids in the concentrating section of the membrane tank, ranging from 3 to $26 \mathrm{~L}$. The obtained data regarding the solids in the purge stream, in the filtration section, and in the permeate stream are presented in Table 3.

The strategy of recovering the concentrated solids in a daily frequency or every two days with variable volumes has been shown as feasible and effective. The daily increase of TMPs has been remarkable due to the higher solids concentration in the feed, nevertheless every time the solids purge was performed the TMPs of filtration have decreased, as a result of solids concentration reduction in the membrane module vicinities. In the long-term, however, the predominance of the membrane fouling started to be noticed as indicated by the ascending arrow on the graphic for the TMPs of filtration. The descending arrow on the TMPs of backwash (orange triangular points) suggested that the irreversible fouling is another causing to the tong-term decreasing of membrane permeability since the difficulty for the permeate to flow in countercurrent is associated with internal fouling on the structure of the fibers [22]. This fouling, however, appears to a lesser extent than the reversible fouling, since the cake layer on the external surface of the membrane plays a major role in the fouling formation [32].

Whether daily or every two days of solids purge, high solids concentrations have been achieved from the collected volumes, as a consequence of the high strength feed during this operation period. The concentration process is not disadvantaged, on the contrary, for high strength wastewaters, a higher periodicity of purge can be applied without promoting the dilution of solids. Since the membrane 
filterability was reasonably recovered on almost a daily basis, the volume of filtered wastewater could be maintained as initially set, which means that the permeate productivity was almost the same as the beginning of the experiment, around 12.7 $\mathrm{L} / \mathrm{m}^{2} . \mathrm{h}$, and the TMPs have been kept low and controlled.

\subsection{Effect of daily purge of concentrated solids at constant volume and cleaning in}

\section{place with $\mathrm{NaClO}$ as strategies for fouling control (Experiment S3)}

Constant periodic purges of $6 \mathrm{~L} / \mathrm{d}$ for 16 days, $4 \mathrm{~L} / \mathrm{d}$ for 12 days, and the effect of $\mathrm{NaClO}$ addition were assessed with this operation. The TMP profile for this experiment is shown in Fig. 4.

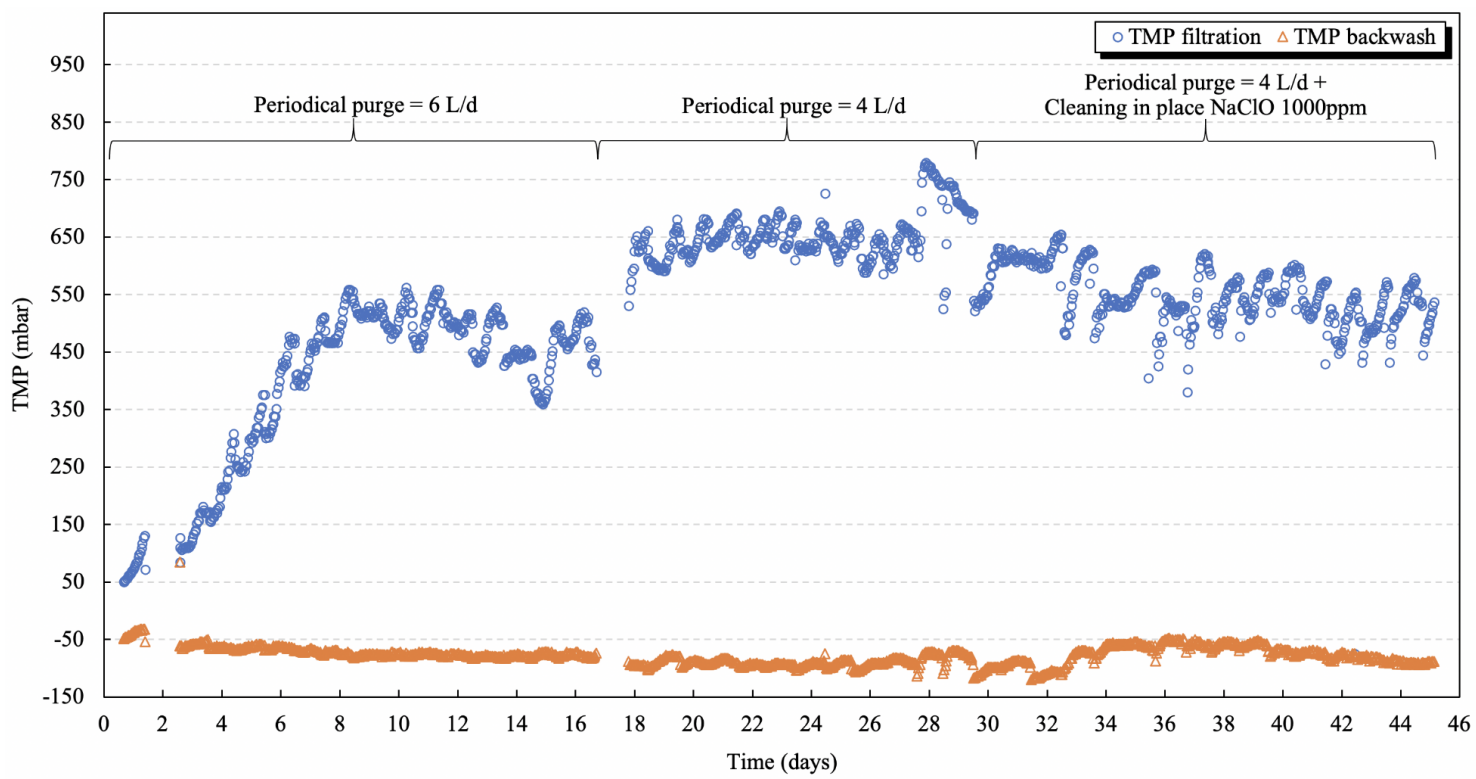

Figure 4 - TMP evolution during the long-term operation with daily purge of concentrated solids at constant volume and cleaning in place with $\mathrm{NaClO}$ as strategies for fouling control combined with intermittent gas scouring ( $13 \mathrm{~m} / \mathrm{h}$ for $40 \mathrm{~s}$ of operation followed by a pause of $3.5 \mathrm{~min}$ ).

At the beginning of the operation, the TMP of filtration (round blue dots) started increasing quickly as a consequence of the primary layer formation over the membrane. Once attached, this fouling is kept in equilibrium with the filtration flux without increasing the TMPs much over 550 mbar. In the meantime, the concentrated solids have been daily purged with a flow of $6 \mathrm{~L} / \mathrm{d}$, resulting in concentrations between 5653 and $32640 \mathrm{mg} / \mathrm{L}$ of COD and between 5600 and $12547 \mathrm{mg} / \mathrm{L}$ in 
terms of TS. Although the concentration of these solids is considered adequate for anaerobic digestion [31], higher concentrations are desired and applied [33-35] in high-solid anaerobic digestion due to the reduction of energy consumption for the reactor heating. In light of this and with the aim of evaluating the TMPs behavior, the volume of the solids purged was lowered to $4 \mathrm{~L} / \mathrm{d}$. By keeping the purge flow and constant tank feed, a lower volume recovered from purge means that the purge concentration would increase. The strategy allowed the recovery of a more concentrated stream between 15147 and 48853 mg/L of COD and between 10010 and $21670 \mathrm{mg} / \mathrm{L}$ of TS. Nevertheless, the consequence for the reduction of the purged solids was the TMPs increasing to around 700 mbar. This means that the reduction of purge volume implied an increase of the membrane fouling at the operating conditions assayed.

In the final part of the operation, together with the $4 \mathrm{~L} / \mathrm{d}$ purges, an enhanced permeate backwash has been tried with daily dosing of 1000 ppm NaClO dissolution (16 ppm in the membrane tank), as an additional strategy to reduce the membrane fouling, thus, to increase the membrane permeability. This strategy allowed the TMPs for decreasing to around 500 mbar of pressure, nevertheless, the recovered concentrated solids during this period presented values between 8235 and 15829 $\mathrm{mg} / \mathrm{L}$ in terms of COD and between 7417 and $14149 \mathrm{mg} / \mathrm{L}$ in terms of TS. Compared to the situation before adding $\mathrm{NaClO}$, the enhanced permeate backwash was efficient for reducing the filtration pressures, but no additional enhancement has been seen for the purge concentration. The lower concentration of the purge might be resulted either from the feeding wastewater characteristics, which during this period presented low content of solids or any oxidation promoted by the $\mathrm{NaClO}$ addition. Table 3 presents the range of concentrations from the purge, filtration section, and permeate stream considering the entire operation. 


\subsection{Effect of the daily addition of different concentrations of $\mathrm{NaClO}$ dissolutions as a strategy for fouling control (Experiment S4)}

This experiment aimed to assess the influence of different concentrations of $\mathrm{NaClO}$ for the fouling removal and the effect in the methane production through BMP assays. The enhanced permeate backwash with $\mathrm{NaClO}$ is notably a feasible, cheaper, and easy practice for reducing the fouling. Since unnecessary stops are undesirable in continuous processes, permeate or enhanced permeate backwash is preferred for being performed in line and with the system in full operation [36].

Three different concentrations of $\mathrm{NaClO}$ have been tested: 250, 500, and 1000 ppm, corresponding respectively to 4, 8, and 16 ppm ideally in the membrane tank. The enhanced permeate backwash was daily performed with $2 \mathrm{~L}$ of the prepared dissolution during 5 days for each dissolution. In Fig. 5 is shown the evolution of the TMPs and the data regarding to solids concentration in the filtration section, purge, and permeate stream are presented in Table 3.

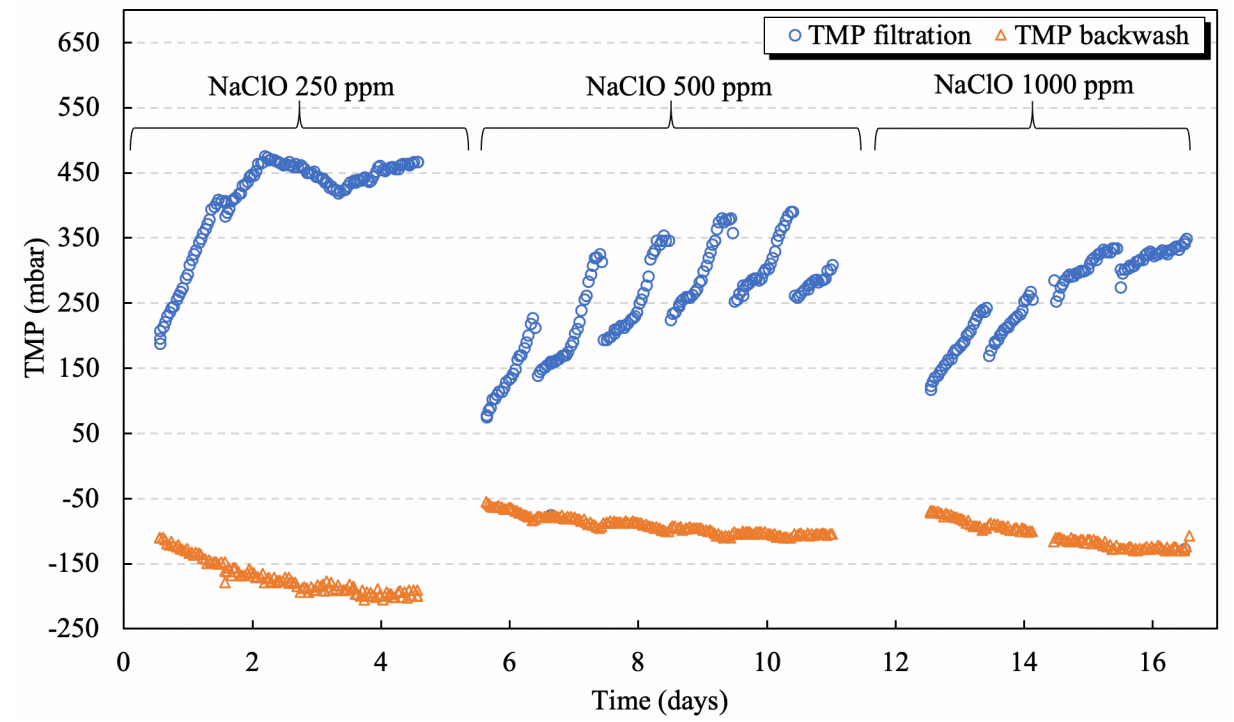

Figure 5 - TMP evolution during the long-term operation for assessing the effect of the daily addition of different concentrations of $\mathrm{NaClO}$ dissolutions (250 pppm, 500 ppm and 1000 ppm) combined with daily purge of concentrated solids and intermittent gas scouring ( $13 \mathrm{~m} / \mathrm{h}$ for $40 \mathrm{~s}$ of operation followed by a pause of $3.5 \mathrm{~min})$. 
When the $\mathrm{NaClO}$ dissolution is applied, the cleaning effect is immediately perceived as a reduction of the TMPs of filtration (round blue dots). The $500 \mathrm{ppm}$ and 1000 ppm dissolution are both adequate for the fouling control, with negligible difference in favor of the 1000 ppm. For these concentrations, the pre-established safe working pressure of 400 mbar was never surpassed, meanwhile, for the 250 ppm dissolution, the TMPs have reached values higher than 450 mbar, even at the beginning of the operation when the membrane module was cleaned. Many authors have reported that low to average concentrations of $\mathrm{NaClO}$ are feasible for fouling mitigation. Indeed, dissolutions of around 100 and 3000 ppm are customarily used in full-scale MBR systems without compromising the filtration performance $[30,37]$. Another noteworthy point is perceived by the TMPs of backwash (triangular orange dots), which presented only a slightly worsening (decrease TMP) during the operation with 500 ppm and 1000 pm, compared to the 250 ppm dissolution. Although the oxidants are mainly applied for the organic fouling removing, which is mainly attached to the membrane surface as a cake layer, the $\mathrm{NaClO}$ dissolution can be a cheaper option for partially dealing with pore blockage [38].

\subsection{Biomethane potential assays performed with samples from the concentrated solids purged along the continuous experiments}

A series of BMP were prepared in order to measure the effectiveness of the polymer additions over the biodegradability of the concentrated solids after the polymer dosings $\left(a_{1}, a_{2}, a_{3}\right.$, and $\left.b_{2}\right)$ and after the enhanced permeate backwash with $\mathrm{NaClO}\left(\mathrm{c}_{1}\right)$ in the experiment $\mathrm{S} 1$. Concentrated solids samples were collected a day after each polymer addition and a day after the enhanced permeate backwash with $\mathrm{NaClO}$ in order to prepare the BMP tests. Results indicated an average to low methane yield production for every sample collected. The SMY, according to the 
samples collected $a_{1}, a_{2}, a_{3}, b_{2}$, and $c_{1}$, were 227, 240, 224, 287, and 272 $\mathrm{mLCH}_{4} / \mathrm{gVS}_{\text {subs, }}$ respectively.

According to the characteristics of wastewater, a low to medium methane production was expected based on the low content of organic matter and the high fraction of fixed solids (Table 2). The polyelectrolyte Chemifloc $\mathrm{AH} 08$ has slightly influenced the methane production to an unfavorable production rate, since the SMY for the recovered solids before chemicals addition resulted in around $295 \pm 4$ $\mathrm{mLCH}_{4} / \mathrm{gVS}_{\text {subs. }}$. The authors consider that this slightly lower production of methane could be associated to the large floc size resulted from the strong interaction between the Chemifloc $\mathrm{AH} 08$ (anionic) and the Chemifloc $\mathrm{CH} 35$ (cationic). Large floc sizes reduce the mass transfer and induce an inhibitory effect for methane production $[35,39]$.

BMPs assays were also prepared with some of the collected samples of concentrated solids from the experiment S2. Performed BMPs resulted in 307 and $261 \mathrm{mLCH}_{4} / \mathrm{gVS}_{\text {subs, }}$, showing a low to medium productivity for that kind of primary solids. The SPWWTP receives a highly variable mixed wastewater from both Santovenia town and from some industries in its proximity. As stated in Table 2, this wastewater (S2) contained a high content of particulate matter, which is notorious for the high concentration of total COD with the very low concentration of soluble COD, and high concentrations of TS and TSS. The hardly biodegradable content was also verified by the behavior of the BMPs assays, which have taken over 40 days for a near stabilization. The longer time for stabilizing could be justified by the limitation in the hydrolysis step of the anaerobic digestion [40].

The three operation phases of the experiment S4 have also BMPs assays for evaluating the collected samples of concentrated solids. Results indicated that the biodegradability of the organic matter was not affected by the oxidant cleaning. The 
resulted from specific methane productions were 274,246 and $311 \mathrm{mLCH}_{4} / \mathrm{gVS}_{\text {subs }}$ for the added concentrations 250,500 , and $1000 \mathrm{ppm}$ of $\mathrm{NaClO}$, respectively. These are similar to other BMPs results and indicate that the $\mathrm{NaClO}$ dissolution might not have caused an important adverse effect over the biodegradation of organics probably due to the dilution that takes place by entering into the membrane tank. Other researchers have reported that the $\mathrm{NaClO}$ have promoted inhibition to the microbial activity only at high concentrations [41].

Table 4 compares the obtained results of SMY along the performed experiments in this work with some reported results from the literature using primary sludge with similar, therefore not the same, experimental conditions of incubation. Differences of inoculum ratio $(\mathrm{S} / \mathrm{X})$, inoculum incubation, microbial community and substrate composition may influence the SMY.

Table 4 - Results of specific methane yield (SMY) from primary sludge anaerobic digestion in this work compared to the reported by the literature.

\begin{tabular}{|c|c|c|}
\hline Experiment & $\mathrm{SMY}\left(\mathrm{mLCH}_{4} / \mathrm{gVS}_{\text {subs }}\right)$ & Reference \\
\hline Experiment S1 & $227\left(\mathrm{a}_{1}\right)^{\mathrm{a}} ; 240\left(\mathrm{a}_{2}\right) ; 224\left(\mathrm{a}_{3}\right) ; 287\left(\mathrm{~b}_{2}\right) ;$ and $272\left(\mathrm{c}_{1}\right)$ & \\
\hline Experiment $\mathrm{S} 2$ & $307 ; 261$ & \\
\hline Experiment S4 & 274 (250 ppm) & \\
\hline Primary sludge & 241c; 221; 235; 273; 283; 231; 230; 235 & [42] \\
\hline Primary sludge & 345 & [43] \\
\hline Primary sludge & 378 & {$[44]$} \\
\hline Primary sludge & $188 ; 230$ & [45] \\
\hline Primary sludge & 204 & {$[46]$} \\
\hline Primary sludge & 136 & [47] \\
\hline
\end{tabular}

$a_{1}, a_{2}, a_{3}, b_{2}$ and $c_{1}$ referred to the addition of specific chemicals during the operation.

${ }^{b}$ Concentrations of $\mathrm{NaClO}$ added during the operation.

c Specific methane yield determined in terms of $\mathrm{mLCH}_{4} / \mathrm{gVSS}_{\text {subs }}$ 


\section{Final remarks}

The long-term direct membrane filtration of municipal wastewater upconcentration is feasible by using simple and cheaper strategies. By comparing the different filtration behaviors observed, some techniques stand out among the assessed ones in the pilot plant assayed.

The gas scouring at the intermittent regime can overcome both: the energy consumption issue when it is set with a reasonable frequency and, the possible carbon oxidation issue when the circuit is closed to the atmosphere. Intermittent gas velocities values as lower as $13 \mathrm{~m} / \mathrm{h}$ when combined with periodic purges of concentrated solids allowed the system to operate under controlled TMPs. Higher gas velocities may be applied depending on the thickness of the reversible fouling.

The adequate control of frequency and volume of purge allows for obtaining high concentrations of COD in the concentration section of the membrane tank besides contributing to avoid high concentration of suspended solids on the filtration section, therefore decreasing the membrane fouling.

Daily enhanced permeate backwash with $\mathrm{NaClO}$ dissolution between 500 and 1000 ppm can remove the reversible fouling on the membrane module without affecting the characteristics of the concentrated solids. The irreversible fouling can be addressed by the use of citric acid.

Polyelectrolytes would be appropriate when the wastewater has a high content of colloidal particles. In this case, the charged nature of the wastewater should be considered for the adequate application of cationic or anionic chemicals. 


\section{Conclusions}

The direct membrane filtration of municipal wastewater in the long-term has been operated under different strategies for fouling control. The membrane filterability, the permeate quality, and the achievement of high solids concentration can be preserved when the system is operated under the combination of the most common and cheaper antifouling practices. The intermittent gas scouring is efficient for controlling the fouling formation at lower gas velocity, like $13 \mathrm{~m} / \mathrm{h}$, when applied combined with daily or short-term periodic purge of concentrated solids, which could present COD concentrations between 2362 and $48853 \mathrm{mg} / \mathrm{L}$. On another hand, the daily enhanced permeate backwash with $\mathrm{NaClO}$ dissolution between 500 and 1000 ppm is another important practice to control the TMPs of filtration at values under 400 mbar without affecting the biodegradability of the recovered solids during the anaerobic digestion. Also, a combination of intermittent gas scouring at $97 \mathrm{~m} / \mathrm{h}$ with enhanced permeate backwash with the anionic polyelectrolyte $\mathrm{AH} 08$ at 1.5-15 g/L was performed as an alternative to overcome the extent of the fouling formation, even though further studies should be made for ensuring the applicability for more types of municipal wastewater at long-term operations.

\section{Acknowledgments}

This work was supported by the Regional Government of Castilla y León and the EUFEDER (CLU 2017-09 and UIC 071). The authors also would like to thank the CNPq National Council for the Scientific and Technological Development - Brazil, for the PhD scholarship of Thiago A. Nascimento [234006/2014-5]. 


\section{References}

[1] J.M. Garrido, M. Fdz-Polanco, F. Fdz-Polanco, Working with energy and mass balances: A conceptual framework to understand the limits of municipal wastewater treatment, Water Sci. Technol. 67 (2013) 2294-2301. doi:10.2166/wst.2013.124.

[2] A.T. Ubando, C.B. Felix, W.H. Chen, Biorefineries in circular bioeconomy: A comprehensive review, Bioresour. Technol. 299 (2020). doi:10.1016/j.biortech.2019.122585.

[3] N. Libardi, C.R. Soccol, J.C. de Carvalho, L.P. de Souza Vandenberghe, Simultaneous cellulase production using domestic wastewater and bioprocess effluent treatment - A biorefinery approach, Bioresour. Technol. 276 (2019) 42-50. doi:10.1016/j.biortech.2018.12.088.

[4] B. Wu, Membrane-based technology in greywater reclamation: A review, Sci. Total Environ. 656 (2019) 184-200. doi:10.1016/j.scitotenv.2018.11.347.

[5] M. Peña, T. do Nascimento, J. Gouveia, J. Escudero, A. Gómez, A. Letona, J. Arrieta, F. FdzPolanco, Anaerobic submerged membrane bioreactor (AnSMBR) treating municipal wastewater at ambient temperature: Operation and potential use for agricultural irrigation, Bioresour. Technol. 282 (2019) 285-293. doi:10.1016/j.biortech.2019.03.019.

[6] H. Gong, Z. Jin, H. Xu, Q. Yuan, J. Zuo, J. Wu, K. Wang, Enhanced membrane-based preconcentration improves wastewater organic matter recovery: Pilot-scale performance and membrane fouling, J. Clean. Prod. 206 (2019) 307-314. doi:10.1016/j.jclepro.2018.09.209.

[7] S. Hube, M. Eskafi, K.F. Hrafnkelsdóttir, B. Bjarnadóttir, M.Á. Bjarnadóttir, S. Axelsdóttir, B. Wu, Direct membrane filtration for wastewater treatment and resource recovery: A review, Sci. Total Environ. 710 (2020) 136375. doi:10.1016/j.scitotenv.2019.136375.

[8] T.A. Nascimento, F. Fdz-polanco, M. Peña, T.A. Nascimento, F. Fdz-polanco, M. Peña, Membrane-Based Technologies for the Up- Concentration of Municipal Wastewater : A Review of Pretreatment Intensification, Sep. Purif. Rev. $00 \quad$ (2018) 1-19. doi:10.1080/15422119.2018.1481089.

[9] X. Shi, G. Tal, N.P. Hankins, V. Gitis, Fouling and cleaning of ultrafiltration membranes: A review, J. Water Process Eng. 1 (2014) 121-138. doi:10.1016/j.jwpe.2014.04.003.

[10] M. Chai, Y. Ye, V. Chen, Separation and concentration of milk proteins with a submerged membrane vibrational system, J. Memb. Sci. $524 \quad$ (2017) 305-314. doi:10.1016/j.memsci.2016.11.043.

[11] W. Xue, M. Jian, T. Lin, B. Ma, R. Wu, X. Li, A novel strategy to alleviate ultrafiltration membrane fouling by rotating membrane module, Chemosphere. $260 \quad$ (2020) 127535. doi:10.1016/j.chemosphere.2020.127535.

[12] S. Aghapour Aktij, A. Taghipour, A. Rahimpour, A. Mollahosseini, A. Tiraferri, A critical review on ultrasonic-assisted fouling control and cleaning of fouled membranes, Ultrasonics. 108 (2020) 106228. doi:10.1016/j.ultras.2020.106228.

[13] N. Wang, X. Li, Y. Yang, Z. Zhou, Y. Shang, X. Zhuang, Photocatalysis-coagulation to control ultrafiltration membrane fouling caused by natural organic matter, J. Clean. Prod. 265 (2020) 121790. doi:10.1016/j.jclepro.2020.121790.

[14] A. Khosravanipour Mostafazadeh, M. Zolfaghari, P. Drogui, Electrofiltration technique for water and wastewater treatment and bio-products management: A review, J. Water Process Eng. 14 
(2016) 28-40. doi:10.1016/j.jwpe.2016.10.003.

[15] E.O. Ezugbe, S. Rathilal, Membrane technologies in wastewater treatment: A review, Membranes (Basel). 10 (2020). doi:10.3390/membranes10050089.

[16] Z. Wang, J. Ma, C.Y. Tang, K. Kimura, Q. Wang, X. Han, Membrane cleaning in membrane bioreactors: A review, J. Memb. Sci. 468 (2014) 276-307. doi:10.1016/j.memsci.2014.05.060.

[17] N. Porcelli, S. Judd, Chemical cleaning of potable water membranes: A review, Sep. Purif. Technol. 71 (2010) 137-143. doi:10.1016/j.seppur.2009.12.007.

[18] J.C. Te Lin, D.J. Lee, C. Huang, Membrane fouling mitigation: Membrane cleaning, Sep. Sci. Technol. 45 (2010) 858-872. doi:10.1080/01496391003666940.

[19] R.W. Field, G.K. Pearce, Critical, sustainable and threshold fluxes for membrane filtration with water industry applications, Adv. Colloid Interface Sci. 164 (2011) 38-44. doi:10.1016/j.cis.2010.12.008.

[20] S. Hube, J. Wang, L.N. Sim, T.H. Chong, B. Wu, Direct membrane filtration of municipal wastewater: Linking periodical physical cleaning with fouling mechanisms, Sep. Purif. Technol. 259 (2021) 118125. doi:10.1016/j.seppur.2020.118125.

[21] G. Mezohegyi, M.R. Bilad, I.F.J. Vankelecom, Direct sewage up-concentration by submerged aerated and vibrated membranes, Bioresour. Technol. 118 (2012) 1-7. doi:10.1016/j.biortech.2012.05.022.

[22] K. Kimura, K. Kume, Irreversible fouling in hollow-fiber PVDF MF/UF membranes filtering surface water: Effects of precoagulation and identification of the foulant, J. Memb. Sci. 602 (2020) 117975. doi:10.1016/j.memsci.2020.117975.

[23] APHA/AWWA/WEF, Standard Methods for the Examination of Water and Wastewater, 2012.

[24] S.K. Lateef, B.Z. Soh, K. Kimura, Direct membrane filtration of municipal wastewater with chemically enhanced backwash for recovery of organic matter, Bioresour. Technol. 150 (2013) 149-155. doi:10.1016/j.biortech.2013.09.111.

[25] A. Cainglet, A. Tesfamariam, E. Heiderscheidt, Organic polyelectrolytes as the sole precipitation agent in municipal wastewater treatment, J. Environ. Manage. 271 (2020) 111002. doi:10.1016/j.jenvman.2020.111002.

[26] C.S. Lee, J. Robinson, M.F. Chong, A review on application of flocculants in wastewater treatment, Process Saf. Environ. Prot. 92 (2014) 489-508. doi:10.1016/j.psep.2014.04.010.

[27] B. Bolto, J. Gregory, Organic polyelectrolytes in water treatment, Water Res. 41 (2007) 23012324. doi:10.1016/j.watres.2007.03.012.

[28] S.A. Yousefi, M.S. Nasser, I.A. Hussein, A. Benamor, Enhancement of flocculation and dewaterability of a highly stable activated sludge using a hybrid system of organic coagulants and polyelectrolytes, J. Water Process Eng. 35 (2020). doi:10.1016/j.jwpe.2020.101237.

[29] M.A.A. Razali, Z. Ahmad, M.S.B. Ahmad, A. Ariffin, Treatment of pulp and paper mill wastewater with various molecular weight of polyDADMAC induced flocculation, Chem. Eng. J. 166 (2011) 529-535. doi:10.1016/j.cej.2010.11.011.

[30] Z. Wang, J. Ma, C.Y. Tang, K. Kimura, Q. Wang, X. Han, Membrane cleaning in membrane bioreactors: A review, J. Memb. Sci. 468 (2014) 276-307. 
doi:10.1016/j.memsci.2014.05.060.

[31] E. Metcalf, H. Eddy, Wastewater engineering: treatment and reuse, 4th ed., McGraw-Hill, New York, 2003.

[32] W. Guo, H.-H. Ngo, J. Li, A mini-review on membrane fouling., Bioresour. Technol. 122 (2012) 27-34. doi:10.1016/j.biortech.2012.04.089.

[33] L. Lianhua, L. Dong, S. Yongming, M. Longlong, Y. Zhenhong, K. Xiaoying, Effect of temperature and solid concentration on anaerobic digestion of rice straw in South China, Int. J. Hydrogen Energy. 35 (2010) 7261-7266. doi:10.1016/j.ijhydene.2010.03.074.

[34] A. Abbassi-Guendouz, D. Brockmann, E. Trably, C. Dumas, J.P. Delgenès, J.P. Steyer, R. Escudié, Total solids content drives high solid anaerobic digestion via mass transfer limitation, Bioresour. Technol. 111 (2012) 55-61. doi:10.1016/j.biortech.2012.01.174.

[35] F. Di Capua, D. Spasiano, A. Giordano, F. Adani, U. Fratino, F. Pirozzi, G. Esposito, High-solid anaerobic digestion of sewage sludge: challenges and opportunities, Appl. Energy. 278 (2020) 115608. doi:10.1016/j.apenergy.2020.115608.

[36] S. Judd, C. Judd, The MBR Book: Principles and Applications of Membrane Bioreactors for Water and Wastewater Treatment, 2nd ed., Butterworth-Heinemann, Oxford, UK, 2011. doi:10.1016/B978-0-08-096682-3.10007-1.

[37] M.K. Shahid, A. Kashif, P.R. Rout, M. Aslam, A. Fuwad, Y. Choi, R. Banu J, J.H. Park, G. Kumar, A brief review of anaerobic membrane bioreactors emphasizing recent advancements, fouling issues and future perspectives, J. Environ. Manage. 270 (2020) 110909. doi:10.1016/j.jenvman.2020.110909.

[38] C.H. Wei, X. Huang, R. Ben Aim, K. Yamamoto, G. Amy, Critical flux and chemical cleaning-inplace during the long-term operation of a pilot-scale submerged membrane bioreactor for municipal wastewater treatment, Water Res. 45 (2011) 863-871. doi:10.1016/j.watres.2010.09.021.

[39] C.P. Chu, D.J. Lee, B.V. Chang, C.H. You, C.S. Liao, J.H. Tay, Anaerobic digestion of polyelectrolyte flocculated waste activated sludge, Chemosphere. 53 (2003) 757-764. doi:10.1016/S0045-6535(03)00553-8.

[40] E. Morgenroth, R. Kommedal, P. Harremoës, Processes and modeling of hydrolysis of particulate organic matter in aerobic wastewater treatment - a review, Water Sci. Technol. 45 (2002) 25-40. doi:10.2166/wst.2002.0091.

[41] X. Han, Z. Wang, X. Wang, X. Zheng, J. Ma, Z. Wu, Microbial responses to membrane cleaning using sodium hypochlorite in membrane bioreactors: Cell integrity, key enzymes and intracellular reactive oxygen species, Water Res. 88 (2016) 293-300. doi:10.1016/j.watres.2015.10.033.

[42] E. Elbeshbishy, G. Nakhla, H. Hafez, Biochemical methane potential (BMP) of food waste and primary sludge: Influence of inoculum pre-incubation and inoculum source, Bioresour. Technol. 110 (2012) 18-25. doi:10.1016/j.biortech.2012.01.025.

[43] W. Wei, Z. Cai, J. Fu, G.J. Xie, A. Li, X. Zhou, B.J. Ni, D. Wang, Q. Wang, Zero valent iron enhances methane production from primary sludge in anaerobic digestion, Chem. Eng. J. 351 (2018) 1159-1165. doi:10.1016/j.cej.2018.06.160. 
[44] M. Solé-Bundó, H. Salvadó, F. Passos, M. Garfí, I. Ferrer, Strategies to optimize microalgae conversion to biogas: Co-digestion, pretreatment and hydraulic retention time, Molecules. 23 (2018) 1-16. doi:10.3390/molecules23092096.

[45] F. Sakaveli, M. Petala, V. Tsiridis, E. Darakas, Enhanced Mesophilic Anaerobic Digestion of Primary Sewage Sludge, Water. 13 (2021) 348. doi:10.3390/w13030348.

[46] T. Yuan, Y. Cheng, Z. Zhang, Z. Lei, K. Shimizu, Comparative study on hydrothermal treatment as pre- and post-treatment of anaerobic digestion of primary sludge: Focus on energy balance, resources transformation and sludge dewaterability, Appl. Energy. 239 (2019) 171-180. doi:10.1016/j.apenergy.2019.01.206.

[47] S. Xie, X. Li, C. Wang, J. Kulandaivelu, G. Jiang, Enhanced anaerobic digestion of primary sludge with additives: Performance and mechanisms, Bioresour. Technol. 316 (2020) 123970. doi:10.1016/j.biortech.2020.123970. 
CHAPTER 7 | Control strategies for the long-term operation of DMF of municipal wastewater 



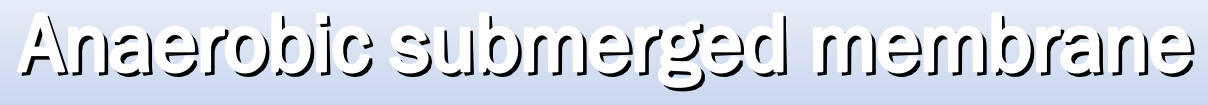

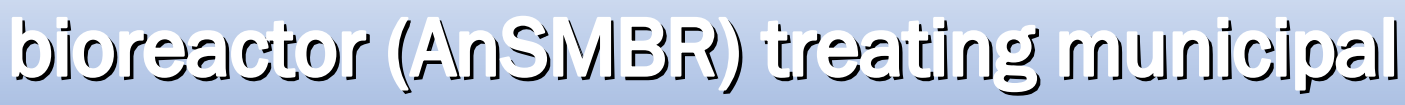

wastewarter at ann.ojent tensperanduses

operation and potential use for

agriculitural irrigation

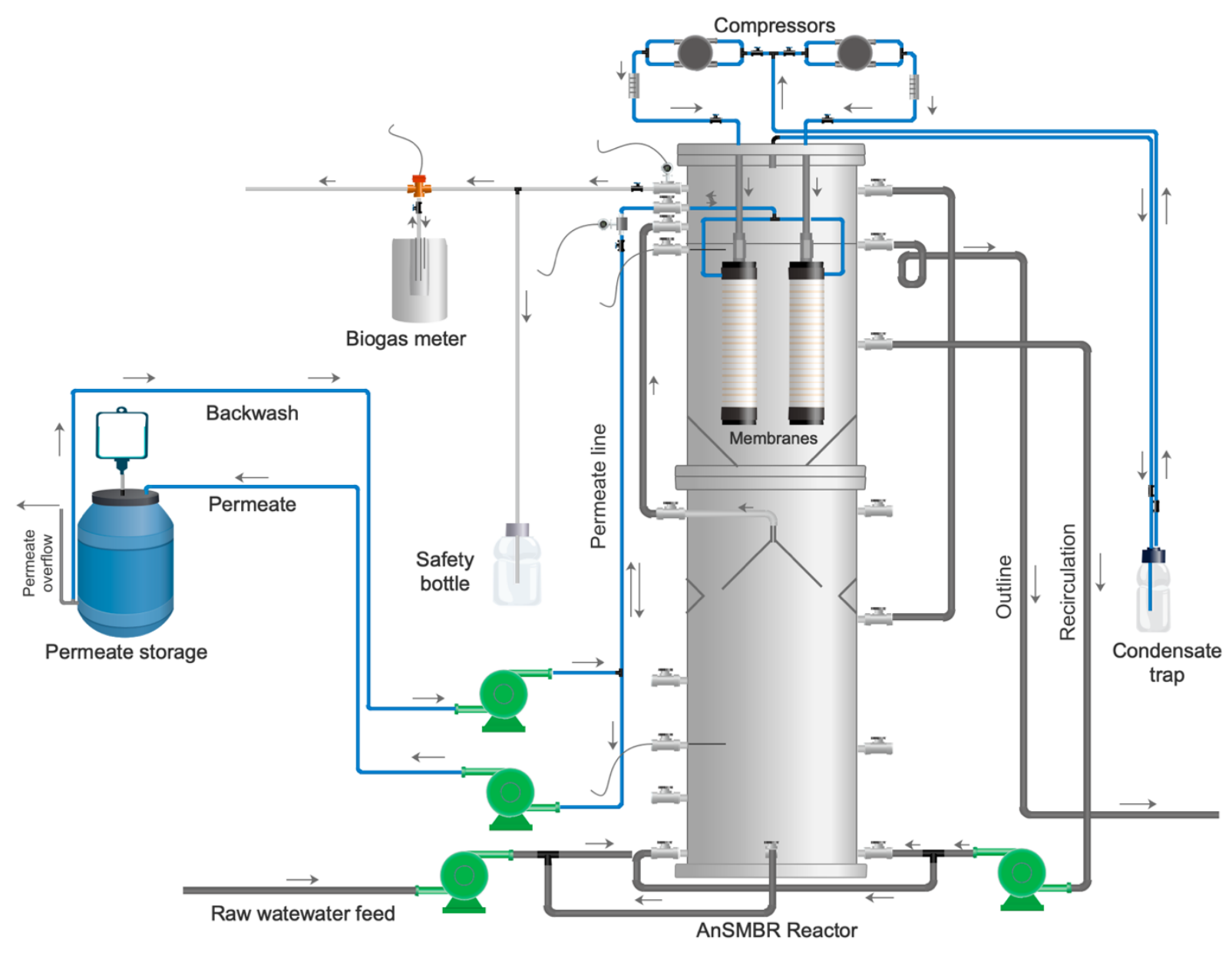





\title{
Anaerobic submerged membrane bioreactor (AnSMBR) treating municipal wastewater at ambient temperature: Operation and potential use for agricultural irrigation.
}

\author{
Mar Peñaa,b* , Thiago do Nascimento ${ }^{a, b}$, Joao Gouveiaa, Julián Escuderoc , Alicia \\ Gómez ${ }^{\mathrm{d}}$, Alberto Letonad , Javier Arrietad , Fernando Fdz-Polanco ${ }^{\mathrm{a}, \mathrm{b}}$ \\ a Department of Chemical Engineering and Environmental Technology, University of Valladolid \\ b Institute of Sustainable Processes, University of Valladolid, Dr. Mergelina s/n, 47011. Valladolid. \\ Spain. \\ c CADAGUA S.A., Crtra RM 714, km 3.5, 30520 Jumilla, Murcia, Spain \\ d I+D+i, CADAGUA S.A., Gran Vía 45, 8 a Planta, 48011, Bilbao, Spain \\ *Corresponding author. Tel.: +34 983423166. E-mail address: pena@iq.uva.es*
}

\begin{abstract}
A 496 L pilot scale anaerobic submerged membrane bioreactor (AnSMBR) for the treatment of municipal wastewater was evaluated during a year of stable operation at ambient $\left(28-10^{\circ} \mathrm{C}\right)$ temperature and inoculated with mesophilic inoculum. The temperature was the main parameter affecting the process performance. The chemical oxygen demand (COD) of the effluent was around 150 $\mathrm{mg} \mathrm{O}_{2} / \mathrm{L}$ in the summer period, operating with a volumetric loading rate (VLR) of $5 \mathrm{~kg}$ $\mathrm{COD} / \mathrm{m}^{3} \mathrm{~d}$ and hydraulic retention time (HRT) of $8-10 \mathrm{~h}$, with a specific methane production between $0.09-0.14 \mathrm{Nm}^{3} / \mathrm{kgCOD}_{\text {removed. }}$ However, during the winter season, an important increase of effluent COD was observed, and therefore the VLR was decreased to values around $1 \mathrm{~kg} \operatorname{COD} / \mathrm{m}^{3} \mathrm{~d}$ in order to recover the quality of the effluent. Biogas production was negligible in this period. The effluent complies with the parameters stipulated by Spanish law regarding the use of treated wastewater for agricultural irrigation.
\end{abstract}

\section{Keywords}

Anaerobic membrane bioreactor, ambient temperature, biogas, agricultural irrigation, pathogens. 


\section{Introduction}

The rising demand for freshwater to meet the growth in the world's population, together with an unsustainable management of resources in many cases, can affect water supply in terms of quality and quantity, and therefore increase the existing pressures on water resources [1]. The concern about water scarcity now demands an appropriate management of available water resources and the development of new wastewater treatment methods. For this reason, in recent years municipal wastewater has been regarded more as a resource rather than a waste, especially for the current global scenario which faces severe risks such as climate change, energy crises and water scarcity [2]. The reutilization of treated wastewater can be an important objective in environmental protection and conservation of resources [3]. If it is properly treated, wastewater can simultaneously address the problems of freshwater scarcity and environmental pollution. Thus, municipal wastewater can become an important source of re-usable water, fertilizer, soil conditioner and energy supply. Even so, it is important to take into account that in order to be safe and reliable, the reused water requires the adequate removal of salts, pathogenic agents, and traces of organic chemicals from the reclaimed effluent.

Municipal wastewater treatment plants have the potential to become net producers of renewable energy, by converting the energy content in the organic pollutants of raw municipal wastewater to useful energy carried in the form of methane-rich biogas produced during anaerobic digestion [4]. In light of this, the selection of an appropriate energy recovery technology able to directly convert the inherent energy in wastewater into an energy source is a fundamental challenge. We should therefore devote more effort to the development or the adoption of novel treatment configurations and emerging technologies [5]. 
The anaerobic treatment process perfectly matches with the concept needed for the municipal wastewater treatment, however, the dependence of operational temperature is still a matter of concern $[2,6]$. Anaerobic treatment at low temperature with non-acclimated sludge still has limitations that need to be studied, even using anaerobic membrane bioreactors. It is also important to consider dissolved methane in the anaerobic treatment of municipal wastewaters as an important downside [7].

The Anaerobic membrane bioreactor (AnMBR) has been attracting attention as a way to treat different low strength wastewater using different membrane configurations $[8,9]$. The use of membranes as a physical barrier allows the retention of the biomass, hindering the washout of the reactor. Moreover, depending on membrane pore size, the quality of the effluent is improved due to the solids rejection. The permeate could be used for agriculture irrigation due to the nutrients content since macronutrients such as ammonia and orthophosphate are not removed by anaerobic processes. Moreover, pathogens can be retained by the membrane unit depending on its pore size [10].

If the microbial quality of the treated wastewater is found to be inadequate, this could limit its agricultural use; however, if municipal wastewater treatment is carried out in an anaerobic membrane bioreactor, the permeate could contain the properties required by the treated wastewater reuse regulations. Numerous studies have been carried out in order either to determine the quality of municipal wastewater after different refining treatments [11,12] or to directly assess the secondary effluent [1] in order to determine its effect on different crops and soil $[13,14]$. The effect of the long-term application of treated wastewater on the properties and characteristics of the soil, both in humid areas [15] and in arid areas where water scarcity is a major problem, has also been analyzed $[16,17]$. However, to the best of our knowledge, few studies have been carried out assessing the 
microbiological characteristics of municipal wastewater treated in an anaerobic membrane bioreactor.

With this background in mind, the aim of this work is to study the effect of temperature over the parameters of operation in an anaerobic membrane bioreactor operating in actual environmental conditions. The effect of temperature on the volumetric loading rate and the production of methane was studied, as well as the membrane performance. The microbial quality and physicochemical characteristics of the permeate are analyzed for its potential use in agriculture irrigation.

\section{Materials and methods}

\subsection{AnSMBR configuration}

Fig. 1 shows the outline of the pilot scale AnSMBR. The reactor is divided into two zones, the upper part, where the ultrafiltration membranes were located, and a lower part or biological section, equivalent to an UASB reactor, where the anaerobic biodegradation of the organic matter takes place. The internal diameter of the AnSMBR is $0.42 \mathrm{~m}$. The total volume of the biological section is $318 \mathrm{~L}$ and, the total volume of the filtration section is $178 \mathrm{~L}$. The AnSMBR was equipped with two hollow fiber membrane modules, (ZW-10 Zenon, GE), with a mean pore size of $0.045 \mu \mathrm{m}$ and a filtration area of $0.93 \mathrm{~m}^{2} /$ module. Biogas sparging, relaxation time, and permeate back-flush were used as methods to control membrane fouling and to maintain the trans-membrane pressure (TMP). The filtration cycle was fixed at: 0.5 minute back-flush, 5 seconds relaxation, 7.5 minutes filtration, and 5 seconds relaxation. Thus, the filtration time represented $91.91 \%$ of the total filtration cycle. The biogas was continuously sparged, (coarse bubbles) onto the bottom of the hollow fibers. The AnSMBR is equipped with biogas, temperature and pressure meters and the data is stored online using the Picolog Technology Ltd. data acquisition system. 


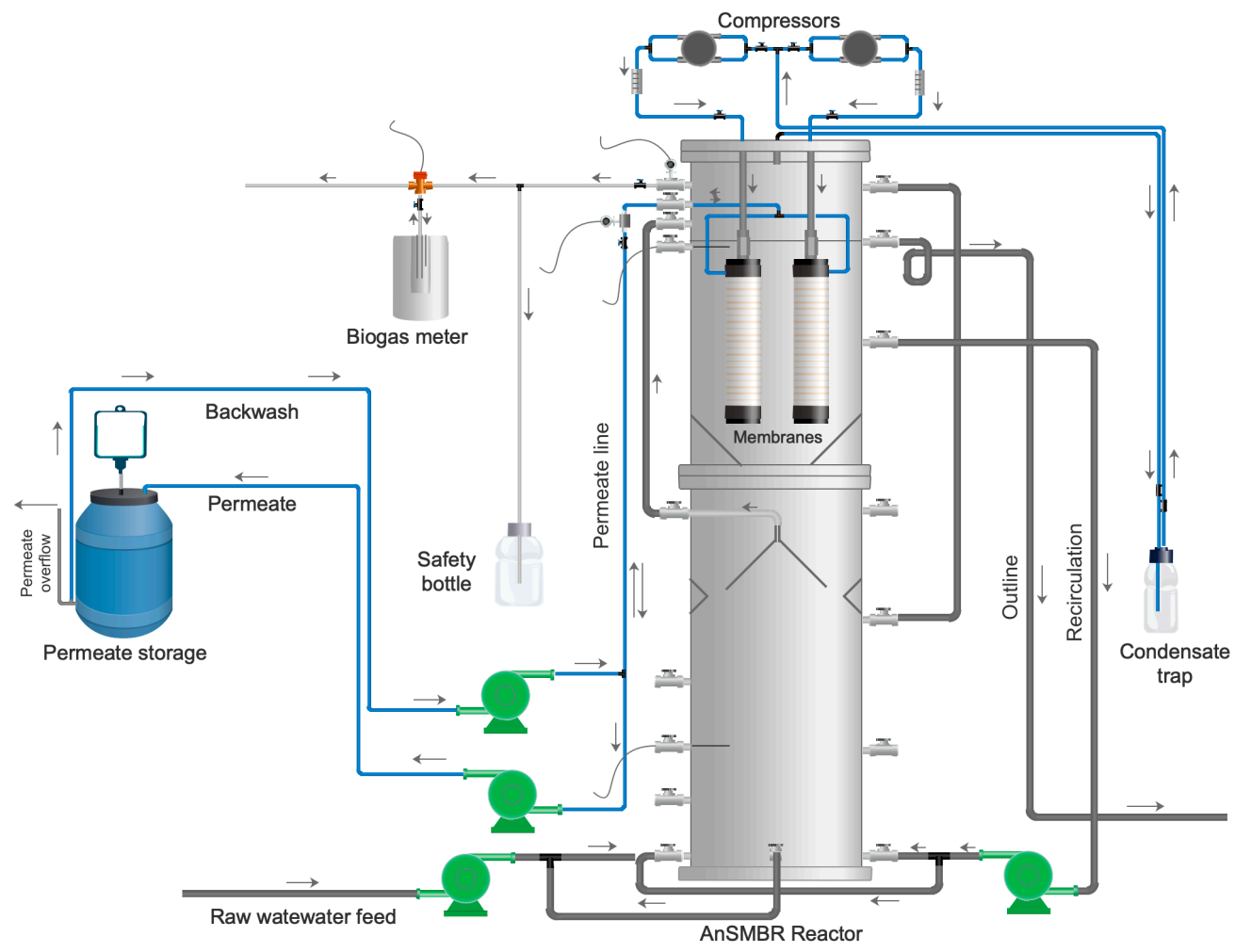

Figure 1 - Schematic diagram of the pilot scale AnMBR set-up.

\subsection{Experimental operation of the pilot plant AnSMBR}

The pilot plant operation started in May 2016 and continued operating until August of the following year. The AnSMBR was located inside an industrial unit and operated at ambient temperature, in both the winter and summer periods. The UASB reactor was continuously fed with municipal wastewater from the grit chamber. The initial VLR was set at $1 \mathrm{~kg} \mathrm{tCOD} / \mathrm{m}^{3} \mathrm{~d}$ and was gradually increased by increasing the flow rate, resulting in a gradual decrease of the HRT.

The superficial velocity in the UASB was maintained at between $0.2-0.4 \mathrm{~m} / \mathrm{h}$, except during the period of higher VLR, when the superficial velocity rose to $0.6 \mathrm{~m} / \mathrm{h}$. As shown in Table 1, the wastewater feed had a high and variable tCOD concentration. The percentage of particulate COD varied at around $65 \%$ in the first months, while during the rest of period it increased up to values of around $85 \%$. This high particulate COD was due to the uncontrolled discharge into the WWTP, and to the accumulation of solids in the tank. 
Table 1 - Characterization of the municipal wastewater at the UASB inlet.

\begin{tabular}{ccc}
\hline Parameter & Unit & $\begin{array}{c}\text { Concentration } \\
\text { (average } \pm \text { standard deviation) }\end{array}$ \\
\hline Total COD & $\mathrm{mg} / \mathrm{L}$ & $1729 \pm 914$ \\
Soluble COD & $\mathrm{mg} / \mathrm{L}$ & $372 \pm 149$ \\
Total suspended solids (TSS) & $\mathrm{mg} / \mathrm{L}$ & $964 \pm 707$ \\
Volatile suspended solids (VSS) & $\mathrm{mg} / \mathrm{L}$ & $675 \pm 651$ \\
$\mathrm{pH}$ & & $8.2 \pm 0.3$ \\
Alcalinity & $\mathrm{mg} \mathrm{CaCO} / \mathrm{L}$ & $726 \pm 141$ \\
Volatile fatty acids (VFA) & $\mathrm{mg} / \mathrm{L}$ & $100 \pm 80$ \\
Total nitrogen (total N) & $\mathrm{mg} / \mathrm{L}$ & $175 \pm 106$ \\
Ammonium nitrogen (NH & $56 \pm 12$ \\
\hline
\end{tabular}

\subsection{Inoculum and feed wastewater}

The AnSMBR reactor was inoculated with $100 \mathrm{~L}(70 \mathrm{~g}$ VS/L) of sludge from a mesophilic anaerobic reactor treating wastewater from a beer factory, without previous acclimatization. The pilot plant was located at the wastewater treatment plant, WWTP, of the city of Jumilla (Spain) and was continuously fed from a tank, which was continuously fed from the grit chamber. The characteristics of the wastewater feed to the UASB reactor is shown in Table 1.

\subsection{Chemical assays and sampling}

Liquid samples were taken twice a week from the influent, filtration section and permeate in order to monitor the process's performance. Alkalinity, total COD (tCOD), soluble COD (SCOD), total solids (TS), volatile solids (VS), total suspended solids (TSS), volatile suspended solids (VSS), total nitrogen (N-T) and ammonia nitrogen $\left(\mathrm{N}^{-\mathrm{NH}_{4}}{ }^{+}\right)$were determined according to the Standard Methods for the Examination of Water and Wastewater [18]. The SCOD was determined, considering a filter size of $0.45 \mu \mathrm{m}$. Nitrate $\left(\mathrm{NO}_{3}^{-}\right)$, nitrite $\left(\mathrm{NO}_{2}^{-}\right)$, chloride $(\mathrm{Cl}-)$, sulfate $\left(\mathrm{SO}_{4}{ }^{2-}\right)$ and

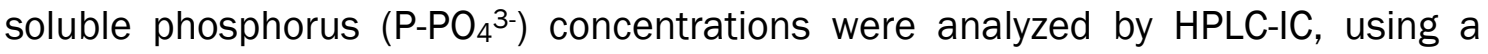
Waters 515 HPLC pump (Waters, Milford, USA) coupled with an ion conductivity 
detector (Waters 432, Milford, USA), and an IC-Pak Anion HC (150 mm×4.6 mm) column (Waters, Milford, USA). Metals were analyzed by inductively coupled plasma atomic emission spectrometry (ICP-AES), using a Graphite Camera and Zeeman Corrector SpectrAA-800 GTA100 by VARIAN. The electrical conductivity was measured by a HACH EC71 conductivity meter. The biogas composition was measured using a gas chromatograph (Varian CP-3800, Palo Alto, CA, USA) coupled with a thermal conductivity detector and equipped with a CP-Molsieve 5A (15 m $\times$ $0.53 \mathrm{~mm} \times 15 \mu \mathrm{m})$ and a CP-Pora BOND Q $(25 \mathrm{~m} \times 0.53 \mathrm{~mm} \times 15 \mu \mathrm{m})$ column. The injector, oven and detector temperatures were $150^{\circ} \mathrm{C}, 40^{\circ} \mathrm{C}$ and $175^{\circ} \mathrm{C}$, respectively. Helium was used as the carrier gas at $13.7 \mathrm{~mL} / \mathrm{min}$.

Microbiological analysis: The enumeration of Escherichia coli in samples from the influent and the permeate was carried out by the membrane filtration method [19] and expressed as colony-forming units per $100 \mathrm{~mL}$ (CFU/100 mL).

The detection and enumeration of viable Helminth eggs was carried out, using water samples from the influent and permeate, by the flotation method using natrium nitrate solution $\left(\mathrm{NaNO}_{3}\right)$, with a specific gravity of 1.35 [20]. The detection and enumeration of Legionella spp, along with the identification of serogroups and Salmonella spp from the influent and permeate samples, was carried out according to the procedures described by ISO 11731:2017 Water quality - enumeration of Legionella [21], and ISO 19250:2013 Water quality- enumeration of Salmonella, respectively [22]. The enumeration of Somatic coliphages and male-specific coliphages from the influent and permeate samples was carried out according to the procedures described by ISO 10705-2:2000 Water quality-detection, and enumeration of bacteriophages-part 2: enumeration of somatic coliphages [23] and ISO 10705-1:1995 Water quality-detection and enumeration of bacteriophages-part 
1: enumeration of F-specific RNA bacteriophages [24] respectively, and was expressed by enumerating plaque-forming units (PFU/mL) .

\subsection{Membrane cleaning and characterization}

The fouled membranes were physically and chemically cleaned and characterized with tap water in order to evaluate the fouling resistance. For the physical cleaning stage, the membranes were subjected to jets of tap water to remove the external solids adhered to the fibers. The chemical cleaning was carried out by soaking the membrane in a $1000 \mathrm{ppm}$ solution of $\mathrm{NaClO}$ at $40^{\circ} \mathrm{C}$ for two hours, and continuous agitation by air injection. Afterwards, the solution was also renewed with $1000 \mathrm{ppm}$ of $\mathrm{NaClO}$ and the membrane was submerged for another two hours. Finally, the filtration and backwash cycle with the $\mathrm{NaClO}$ solution was applied over a further 1.5 hour period. For the characterization stage, each membrane was submerged in tap water at a constant temperature $\left(22-24^{\circ} \mathrm{C}\right)$, and the filtration flow rate was gradually increased in order to correlate the TMP and the permeate flow rate. This characterization was carried out with the fouled membrane after the operation inside the reactor, and after each cleaning procedure in order to determine the permeability and the contribution of each filtration resistance. The total resistance $\left(R_{T}\right)$ was determined by the characterization of the fouled membrane with tap water. This total resistance value includes the inherent resistance $\left(R_{\text {inherent }}\right.$, new membrane), the resistance due to cake layer formation $\left(R_{\text {removable, fouling removed by }}\right.$ the physical cleaning procedure), the resistance due to pore-clogging ( $R_{\text {irreversible, }}$ fouling removed by the chemical cleaning procedure), and the resistance that was not removed during the cleaning procedures $\left(R_{\text {irrecoverable }}\right)$. 


\section{Results and discussion}

\subsection{Volumetric loading rate and COD removal efficiency}

Fig. 2 shows the VLR ( $\mathrm{kg}$ tCOD $/ \mathrm{m}^{3}$ UASB $\mathrm{d}$ ) applied to the UASB reactor, the tCOD of the effluent from the AnSMBR and the temperature during the operation period. As depicted in the figure, during the first period, which lasted until approximately day 160 of operation, dating from the end of May until the beginning of November, the temperature was maintained at between $26-20^{\circ} \mathrm{C}$. At this temperature the volumetric loading rate was gradually increased, reaching values of between $7-8 \mathrm{~kg} \mathrm{tCOD} / \mathrm{m}^{3} \mathrm{UASB}$ $\mathrm{d}$, which implies a HRT inside the UASB reactor of between 6-8 $\mathrm{h}$. Operating under these conditions, the tCOD reached in the effluent was between $130-165 \mathrm{mg} / \mathrm{L}$.

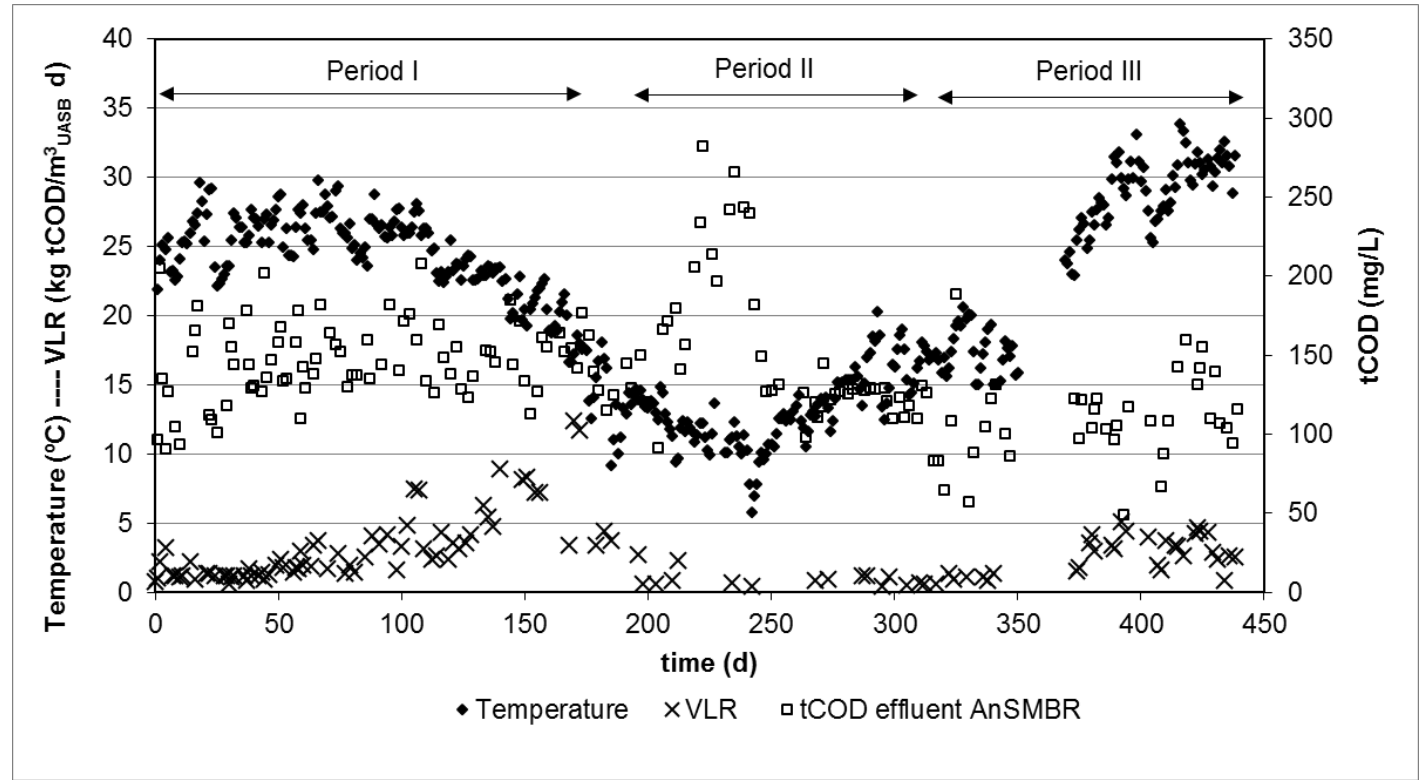

Figure 2 - Evolution of temperature, volumetric loading rate and tCOD of the effluent.

After this period, there was a rapid decrease in the temperature inside the reactor to values of around $10^{\circ} \mathrm{C}$, from mid-November to mid-March, (day 175 to day 300 of operation), approximately. During this period, there was a noticeable decrease in the effluent quality, reaching higher values of tCOD in the effluent, of around 200$250 \mathrm{mg} / \mathrm{L}$. Because of the temperature decrease, the volumetric loading rate was significantly reduced to values around $1-1.5 \mathrm{~kg} t \mathrm{tCOD} / \mathrm{m}^{3} \mathrm{~d}$. Working under these 
conditions, the tCOD of the effluent reached values between 100-130 mg tCOD/L. Other authors showed similar values of the permeate while working at similar conditions. Gao et al. [2], working with an anaerobic fluidized-bed membrane bioreactor treating domestic wastewater with a HRT of $6 \mathrm{~h}$, VLR of $1.44 \mathrm{~kg} \mathrm{COD} / \mathrm{m}^{3} \mathrm{~d}$ at $15^{\circ} \mathrm{C}$, obtained a COD removal yield of $51.1 \%$ with an effluent COD of around 170 mg/L. Watanabe at el. [6] also showed the impact of temperature change. They showed that there was no significant change in the permeate quality when the temperature was lowered from $25^{\circ} \mathrm{C}$ to $20^{\circ} \mathrm{C}$. Nevertheless, if the temperature changes from $20^{\circ} \mathrm{C}$ to $15^{\circ} \mathrm{C}$, the permeate started to get worse significantly and COD concentration increased to $180 \mathrm{mg} / \mathrm{L}$

Finally, during the last period, from approx. day 315 of operation, as a consequence of the temperature increase in the UASB reactor, the VLR $\left(\mathrm{kg}\right.$ COD m${ }^{3}$ UASB d) was again gradually increased to values of around $4 \mathrm{~kg} \operatorname{COD} / \mathrm{m}^{3} \mathrm{~d}$, reaching COD values in the effluent of between $120-140 \mathrm{mg} / \mathrm{L}$ when working with temperatures of around $25^{\circ} \mathrm{C}$.

The temperature has been one of the most important parameters in the operation of the UASB reactor, together with the presence of the membrane. The removal yield of tCOD was practically independent of the VLR applied, reaching a mean value of $85 \pm 6.5 \%$ during the first period of operation, $88 \pm 9.7 \%$ during the period of low temperatures and $94 \pm 3 \%$ during the last period when the temperatures were recovered. The slight difference obtained in the tCOD of the effluent working at a VLR of $4 \mathrm{~kg} \mathrm{tCOD} / \mathrm{m}^{3} \mathrm{~d}$, or increased to $8 \mathrm{~kg} \mathrm{tCOD} / \mathrm{m}^{3} \mathrm{~d}$ at temperatures between $20-24^{\circ} \mathrm{C}$, was due to the presence of the membrane. Ozgun et al. [25] also indicated the important effect on the overall AnMBR treatment performance attributed to the physical membrane barrier. During the period of lower temperatures, the biological activity decreased, and then the tCOD of the effluent 
increased to values of $250 \mathrm{mg} / \mathrm{L}$ when operating with VLR at around $2 \mathrm{~kg} \mathrm{tCOD} / \mathrm{m}^{3}$ d. It was necessary to reduce the VLR to values of around $0.9 \mathrm{~kg} \mathrm{tCOD} / \mathrm{m}^{3} \mathrm{~d}$ in order to make the COD of the effluent decrease to values between $120-100 \mathrm{mg} / \mathrm{L}$ when operating with temperatures between $16-17^{\circ} \mathrm{C}$. The membrane acts as a physical barrier that causes the accumulation of particulate COD inside the UASB reactor and in the filtration section, reaching tCOD values between $15 \mathrm{~g} / \mathrm{L}$ and $20 \mathrm{~g} / \mathrm{L}$, while the soluble COD remained between $150 \mathrm{mg} / \mathrm{L}$ and $500 \mathrm{mg} / \mathrm{L}$ (Fig. 3). On the contrary, the total COD of the permeate was maintained between $150 \mathrm{mg} / \mathrm{L}$ and $100 \mathrm{mg} / \mathrm{L}$ (Fig. 2). This particulate COD accumulation was also shown by Gouveia et al. [26]. As shown in Fig. 3 the higher accumulation rate took place during the period of lower temperatures, although the VLR decreased in this period. This accumulation is most likely due to the decrease in the hydrolysis rate as a consequence of the temperature decrease. The hydrolysis stage of the particulate matter is the limiting factor in the anaerobic treatment at low temperature.

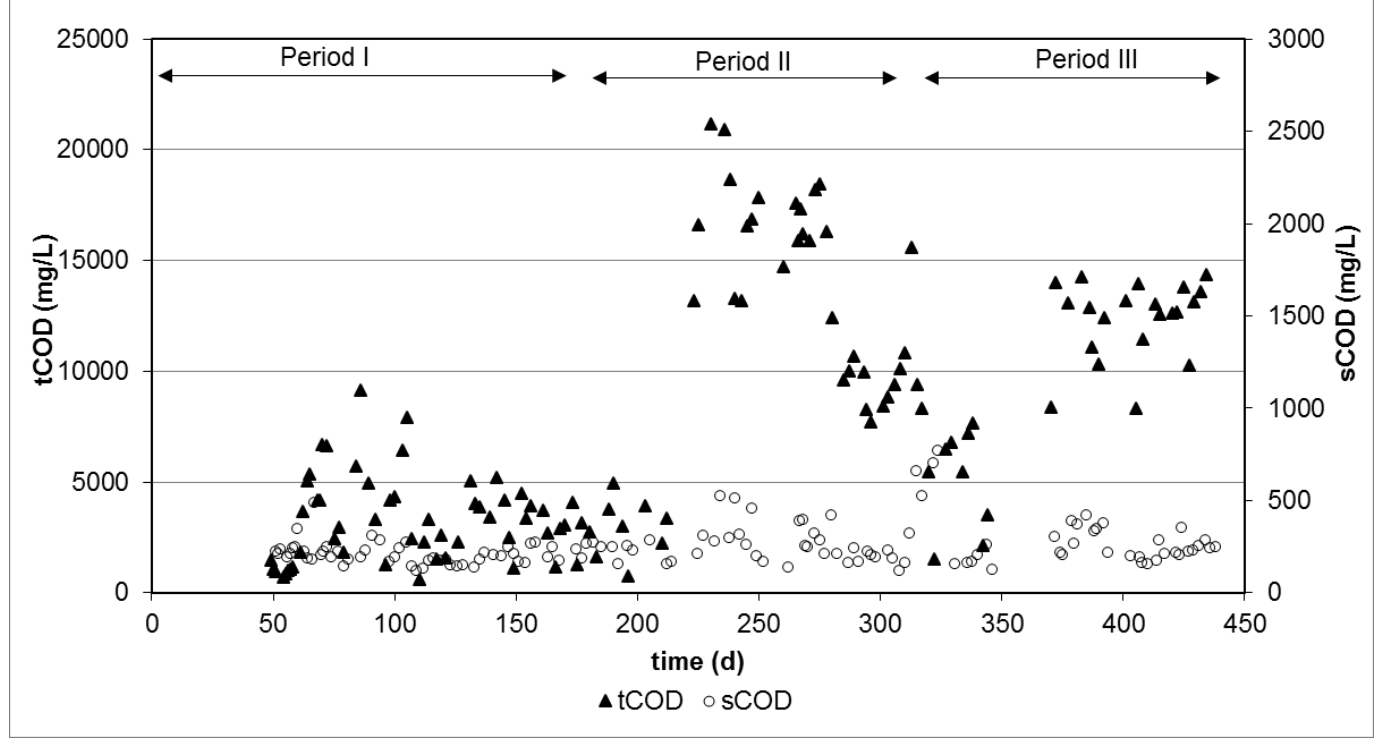

Figure 3 - Evolution of the accumulated COD inside the filtration section of the AnSMBR. 


\subsection{Biogas production and Specific Methane yield in the AnSMBR}

Biogas production and biogas composition were measured periodically. The mean values of the biogas composition were: $65.4 \pm 6.9 \% \mathrm{CH}_{4}, 10.9 \pm 2.9 \% \mathrm{CO}_{2}$, $20.7 \pm 4.1 \% \mathrm{~N}_{2}$ and $0.25 \pm 0.1 \% \mathrm{H}_{2} \mathrm{~S}$. The biogas production was markedly affected by temperature (Fig. 4), with the production decreasing as the temperature decreased (approximately from mid-November to mid-March, from day 175 to day 300 of operation) and increasing again in the last period of operation, when the temperature of the reactor increased. The specific methane yield (SMY), considering the tCOD removed as the difference between the tCOD of the influent and the tCOD of the effluent, was lower than the theoretical value. The average specific methane production was between $0.09-0.14 \mathrm{Nm}^{3} \mathrm{CH}_{4} / \mathrm{kg}$ of the tCOD eliminated during the higher temperature stage. This low specific production was due to the high content of particulate COD in the wastewater, which had been physically removed by the membrane, but not biodegraded. A physical retention of the particulate COD occurred due to the membrane in addition to the biological removal. Moreover, at low temperature the limiting step is the hydrolysis of the particulate matter. However, we should also consider the possible loss of biogas through the membrane, due to the high pressure difference across the membrane that would contribute to the reduction in the registered biogas production. 


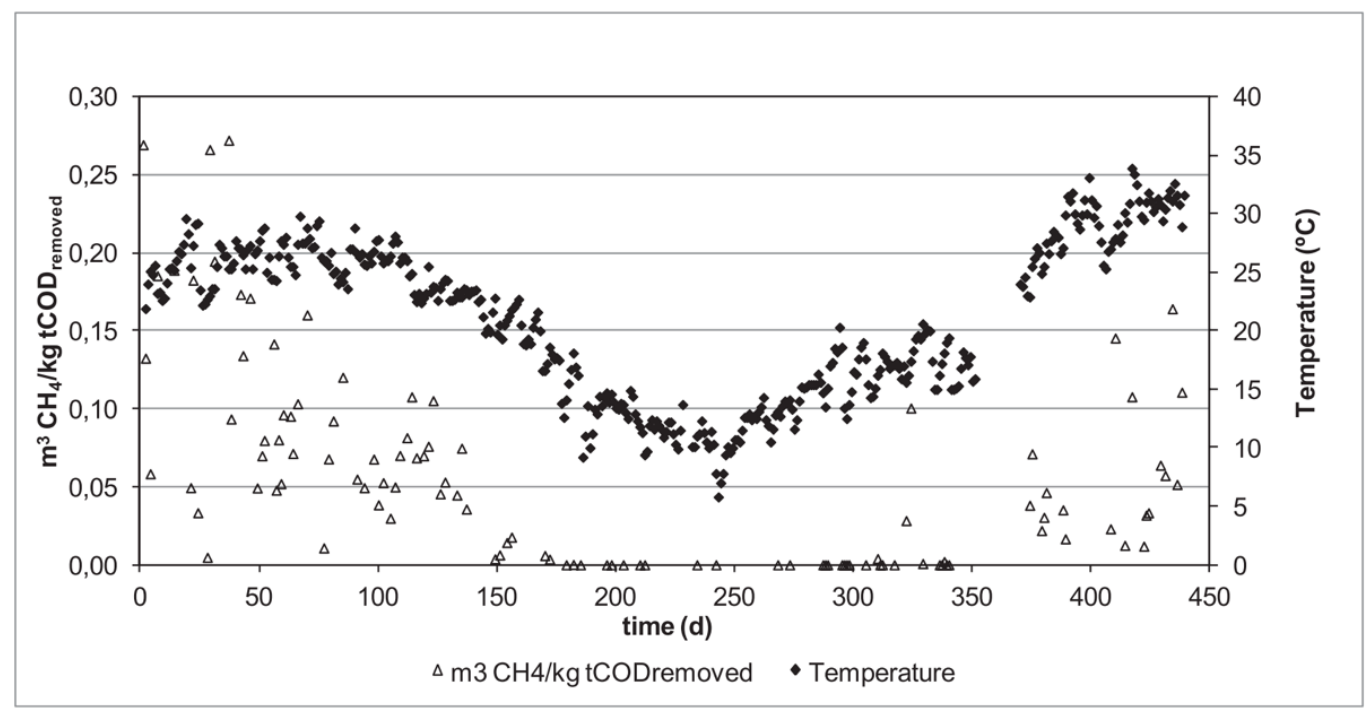

Figure 4 - Evolution of specific methane production and temperature of the UASB reactor.

The SMY obtained was lower than the values found in the bibliography for this type of reactor. Gouveia et al. [27] showed a specific methane yield of 0.226 and $0.216 \mathrm{Nm}^{3} \mathrm{CH}_{4} / \mathrm{kg} \mathrm{tCOD}_{\text {removed }}$ working at $18^{\circ} \mathrm{C} \pm 22^{\circ} \mathrm{C}$ with and without recirculation respectively. The work of Gao et al. [2] shows a methane yield that decreases with temperature, obtaining a value of $0.14 \pm 0.03 \mathrm{Nm}^{3} \mathrm{CH}_{4} / \mathrm{kg} \mathrm{COD}$ at $15{ }^{\circ} \mathrm{C}$. In the present work, during the period in which the mean temperature was $12.6 \pm 1.4^{\circ} \mathrm{C}$, the biogas production was not registered. This could be due to the biological activity decrease as a consequence of the rapid and significant decrease in the temperature, and the lack of acclimation of the sludge to the psychrophilic conditions over such a short timespan. Another fundamental reason for the low specific biogas production during the lower temperature period, as indicated above, was due to the low hydrolysis rate of the particulate matter, which is the limiting step for the removal of particulate COD in the anaerobic process at low temperature. The kinetics of the biological reactions decrease along with the temperature [28], and the microbial communities exhibit different responses to temperature changes. The work of Ozgun et al. [25] showed that the number of species and the phylogenetic diversity decreased when the temperature decreased from $25^{\circ} \mathrm{C}$ to $15^{\circ} \mathrm{C}$. This indicates that 
a temperature decrease may result in a general decrease in microbial diversity within an anaerobic digestion community. Dolejs et al. [29], who studied the effect of the temperature shocks, showed that when psychrophilic conditions were introduced, from $35^{\circ} \mathrm{C}$ to $15^{\circ} \mathrm{C}$, the methane yield dramatically decreased to $0.07 \mathrm{~L} \mathrm{CH}_{4} / \mathrm{g}$ $\mathrm{COD}_{\text {removed, }}$ and after 18 days of operation, the biogas production ceased completely.

Furthermore, as the temperature decreases, the methane solubility increases. This effect therefore contributes to the registered decrease in the biogas production, and to the loss of biogas in the effluent. The contribution of dissolved methane to the total biogas production is different depending on the wastewater COD, temperature and biogas composition. Considering a Henry's constant of $2,97 \mathrm{E}+04 \mathrm{~atm}\left(10^{\circ} \mathrm{C}\right)[30]$ the solubility of the methane is around $0.022 \mathrm{~g} \mathrm{CH}_{4} / \mathrm{L}$ for a methane composition of $75 \%$ in the biogas at atmospheric pressure. According to this, the expected methane loss is $17 \%$ and $88 \%$ for a COD removed of $0.5 \mathrm{~g} / \mathrm{L}$ and $0.1 \mathrm{~g} / \mathrm{L}$ respectively at $10^{\circ} \mathrm{C}$. In contrast at $25^{\circ} \mathrm{C}$ methane loss decreases to $12.6 \%$ and $62.8 \%$ for a COD removed of $0.5 \mathrm{~g} / \mathrm{L}$ and $0.1 \mathrm{~g} / \mathrm{L}$ respectively at the same pressure and biogas composition.

\subsection{Membrane behavior}

Fig. 5 illustrates the performance of the membrane throughout the experimental period of the AnSMBR. Biogas was continuously sparged on the bottom of the hollow fibers, with a superficial biogas velocity of between $5 \mathrm{~m} / \mathrm{h}$ and $12 \mathrm{~m} / \mathrm{h}$, calculated considering a section of $0.1385 \mathrm{~m}^{2}$. During the first period, with temperatures of around $24^{\circ} \mathrm{C}$, the filtration rate was between $10-11 \mathrm{~L} / \mathrm{m}^{2} \mathrm{~h}$ and the TMP was lower than 100 mbar. At this temperature, the filtration rate was increased, reaching a value of $18-19 \mathrm{~L} / \mathrm{m}^{2} \mathrm{~h}$ with a surface velocity of biogas of around $12 \mathrm{~m} / \mathrm{h}$. This high flow rate caused a significant and rapid increase of the filtration TMP, reaching a value of around 750 mbar. 


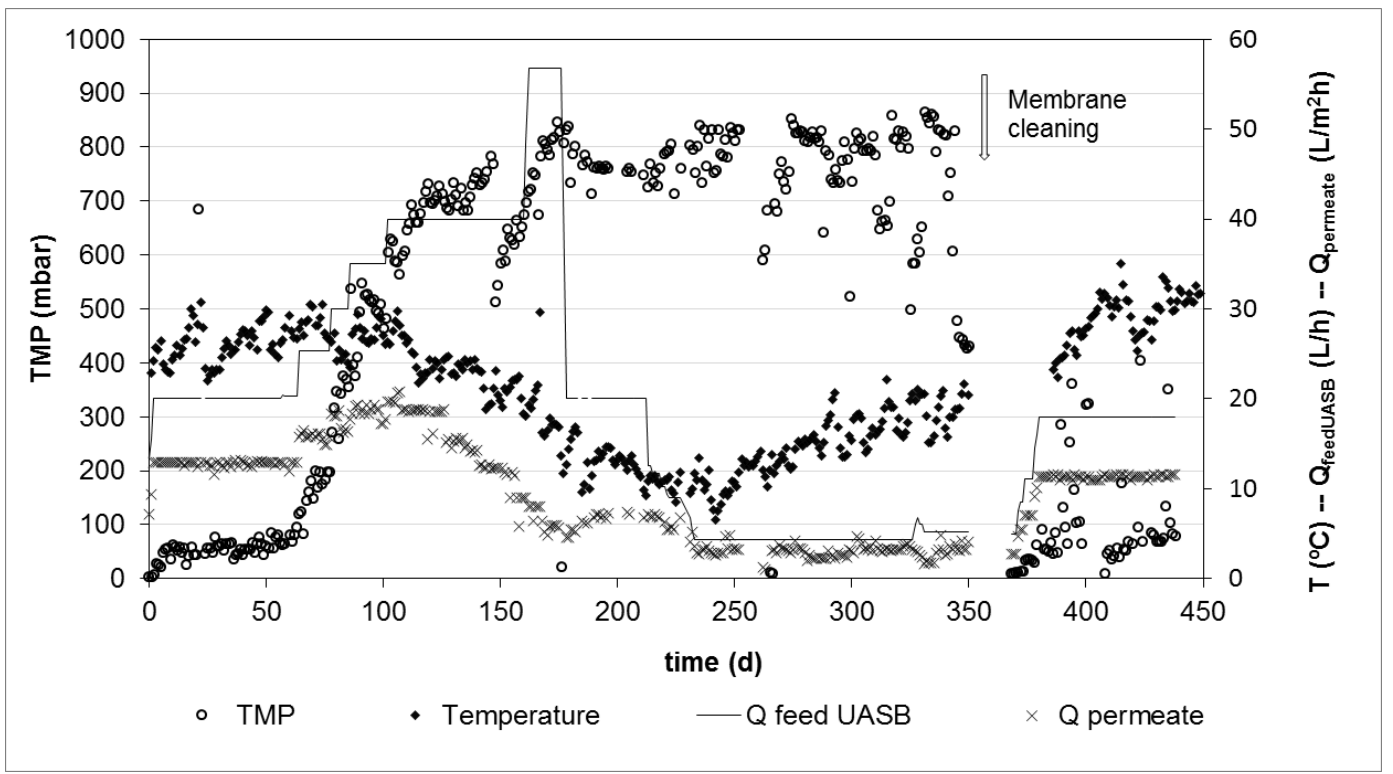

Figure 5 - Evolution of TMP and filtration flow rate.

Coinciding with the pressure increase, a gradual decrease in temperature took place, which caused a decrease in the filtration flow rate, although the feed flow remained constant. This caused an overflow from the filtration zone and, therefore, an uncontrolled purge of the suspension from this section (day 150 to 175 of operation), followed by a slight decrease of the TPM, although the high TMP value was subsequently quickly regained. During the period of lower temperatures, the influent flow rate was reduced to $6-7 \mathrm{~L} / \mathrm{m}^{2} \mathrm{~h}$ and adjusted to the filtrate flow rate, which caused an increase in the accumulated particulate material in the filtration section. However, despite the significant decrease in the filtration flow rate to 2-3.5 $\mathrm{L} / \mathrm{m}^{2} \mathrm{~h}$, and the gradual increase in the operation temperature, the TMP did not decrease, remaining at around 850 mbar. This high value of TMP, which entails a high rate of membrane fouling, was mainly due to the high concentration of particulate COD reached in the filtration zone, and the high flux reached during the first period. Although the flow rate was decreased, the membrane permeability was not recovered. During the last period, after the membrane cleaning, and coinciding with the period of higher temperatures of around $25-28^{\circ} \mathrm{C}$, the permeate flow rate 
was maintained at around $10-12 \mathrm{~L} / \mathrm{m}^{2} \mathrm{~h}$, with the superficial velocity of the biogas being around $9-10 \mathrm{~m} / \mathrm{h}$. Under these conditions, the membrane fouling rate was observed to be negligible, along with a low increase of the filtration pressure. The specific gas demand per permeate throughout the operation was between $55-75 \mathrm{~m}^{3}$ gas $/ \mathrm{m}^{3}$ liquid, which indicates a specific gas demand per membrane area $\left(\mathrm{SGD}_{\mathrm{m}}\right)$ of between $0.66-0.74 \mathrm{~m}^{3}$ biogas $/ \mathrm{m}^{2} \mathrm{~h}$. This is an important parameter related to energy consumption in the AnMBR, which should be minimized. Shin and Bae [8] concluded that the two major factors affecting the energy demand in gas sparging AnMBRs were $\mathrm{SGD}_{\mathrm{m}}$ and operating flux. They show $\mathrm{SGD}_{\mathrm{m}}$ values between $0.15-1.22 \mathrm{Nm}^{3} /\left(\mathrm{m}^{2} \mathrm{~h}\right)$ for pilot-scale anaerobic membrane bioreactors. The work of Wang et al. [31] showed a substantial impact on the fouling rate of the $\mathrm{SGD}_{\mathrm{m}}$ at a continuous filtration flux (13.5 $\left.L /\left(m^{2} h\right)\right)$ and with continuous gas sparging, with $\mathrm{SGD}_{m}$ of between 0.2 and 2 $m^{3} /\left(m^{2} h\right)$. Nevertheless Mei et al. [32] in an optimization protocol for AnMBRs based on energy balance analysis shows that the AnMBR systems at the temperature of $25{ }^{\circ} \mathrm{C}$ for energy-neutral operation, the corresponding fluxes should range from 6.0 to $6.7 \mathrm{~L} /\left(\mathrm{m}^{2} \mathrm{~h}\right)$ with a SGD between $0.22 \mathrm{~m}^{3} /\left(\mathrm{m}^{2} \mathrm{~h}\right)-0.25 \mathrm{~m}^{3} /\left(\mathrm{m}^{2} \mathrm{~h}\right)$.

\subsection{Membrane cleaning}

After a year of operation, due to the high level of fouling, the membranes were physically and chemically cleaned. Table 2 shows the values of the total resistance, and the permeability of each membrane after each cleaning procedure. 
Table 2 - Resistance and permeability of both membranes after the cleaning procedure.

\begin{tabular}{|c|c|c|}
\hline & Resistance $\left(\mathrm{m}^{-1}\right)$ & $\begin{array}{l}\text { Permeability } \\
L /\left(m^{2} h\right) / m b a r\end{array}$ \\
\hline \multicolumn{3}{|l|}{ Membrane I } \\
\hline Before cleaning & $248.45 \times 10^{11}$ & 0.015 \\
\hline After physical cleaning & $25.84 \times 10^{11}$ & 0.139 \\
\hline After chemical cleaning & $9.14 \times 10^{11}$ & 0.394 \\
\hline Startup AnSMBR & $4.77 \times 10^{11}$ & 0.761 \\
\hline Virgin membrane 1 & $3,51 \times 10^{11}$ & 1.021 \\
\hline \multicolumn{3}{|l|}{ Membrane II } \\
\hline Before cleaning & $73.54 \times 10^{11}$ & 0.049 \\
\hline After physical cleaning & $18.47 \times 10^{11}$ & 0.198 \\
\hline After chemical cleaning & $8.47 \times 10^{11}$ & 0.425 \\
\hline Startup AnSMBR & $4.56 \times 10^{11}$ & 0.790 \\
\hline Virgin membrane 2 & $3.21 \times 10^{11}$ & 1.125 \\
\hline
\end{tabular}

As shown in Table 2, the total resistance (RT) reached was very high for both membranes, due to the solids attached to the external surface of the fibers as a consequence of the high concentration of particulate COD reached in the filtration section. The total resistance of membrane I $\left(248.45 \times 10^{11} \mathrm{~m}^{-1}\right)$ was higher than that of membrane II $\left(73.54 \times 10^{11} \mathrm{~m}^{-1}\right)$. This significant difference could be indicative of the non-uniformity of the gas sparging around the membranes and therefore a different fouling rate of each membrane and different permeate flux. Li et al. [33] concluded that the non-uniform distribution of the local fluxes resulted in a change in local permeability, and a different fouling rate of the membrane. The removable resistance ( $R_{\text {removable }}$ ), eliminated by the physical cleaning, contributed highly to the total resistance in the case of both membranes, representing around $89 \%$ and $75 \%$

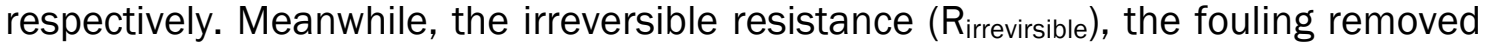
by the chemical cleaning, represented only $7 \%$ and $13 \%$ of the total resistance for membranes I and II respectively. It is difficult to compare these values with literature since the operating conditions and operation time are very different, and therefore 
the contribution to the resistance. Ozgun et al. [25] also indicated that the removable resistance $\mathrm{R}_{\text {removable, }}$ made the highest contribution to the total resistance, however the contribution was lower than that obtained in the present work.

In terms of permeability, both membranes show similar values after the cleaning procedure, with the permeability of membrane I being always slightly lower than that of membrane II. Throughout the operation the membrane suffered a notable loss of filtration capacity, decreasing its permeability from 0.761 $\mathrm{L} /\left(\mathrm{m}^{2} \mathrm{~h}\right) /($ mbar $)$ to $0.394 \mathrm{~L} /\left(\mathrm{m}^{2} \mathrm{~h}\right) /($ mbar $)$ for membrane I, and from 0.790 $\mathrm{L} /\left(\mathrm{m}^{2} \mathrm{~h}\right) /\left(\right.$ mbar) to $0.425 \mathrm{~L} /\left(\mathrm{m}^{2} \mathrm{~h}\right) /($ mbar $)$ for membrane II, after a year's operation in the AnSMBR. The cleaning procedure applied recovered between 57.1 and $57.4 \%$ of the membrane permeability, with respect to the permeability before the operation in the AnSMBR. This recovery depends on the operating conditions, such as solid concentration, permeate flow rate, superficial gas velocity, operation time, and frequency and cleaning procedure. Ozgun et al. [25] showed a permeability recovery of around $96 \%$ when working at $25^{\circ} \mathrm{C}$, whereas at $15^{\circ} \mathrm{C}$ the permeability recovery was around 58\%. In both cases this was achieved by sequential soaking in $200 \mathrm{ppm}$ $\mathrm{NaClO}-0.4 \%$ Divos solution for $30 \mathrm{~min}$ and 1\% (w/v) citric acid solution for one hour. In the present study, the cleaning procedure with $1000 \mathrm{ppm}$ of $\mathrm{NaClO}$ at $40^{\circ} \mathrm{C}$ was not effective enough to recover the permeability. This could be due to the high particulate COD reached at the filtration section, and to having been left for too long without chemical cleaning, which could hinder the transport of the cleaning reagent through the fouling layer. In this sense, Ferrer et al. [34] considered a membrane chemical cleaning frequency that ranged from 2 months (operating at $\mathrm{J} 20=120 \%$ of JC20) to 18 months (operating at J20 $=80 \%$ of JC20). It is necessary to optimize the cleaning procedure in order to decrease the operation costs and to prolong the membrane life. Wang et al. [35] showed that the soaking time of $\mathrm{NaClO}$ had a 
significant effect on the physicochemical properties of PVDF membranes - the negative effect was observed after a soaking time of more than $12 \mathrm{~h}$. Nevertheless, Gao et al. [36] also showed that different exposure doses of Sodium hypochlorite led to variations in PVDF membrane structural/surface characteristics, but the negative effect was observed at an exposure time of $120 \mathrm{~h}$.

\subsection{Agricultural irrigation}

Periodical analysis of the permeate of the AnSMBR pilot plant was carried out in order to determine its suitability for agricultural irrigation according to the Spanish law, R.D. 1620/2007 [37], regarding the reuse of treated wastewater. This normative categorizes treated wastewater for agricultural irrigation into three different Qualities. Quality 1 is the most restrictive, and dictates that the treated wastewater may be used for agricultural irrigation, in direct contact with the edible parts of vegetables for fresh consumption by humans. The most significant parameters analyzed are shown in Table 3, together with the maximum admissible value (MAV) for the most restrictive quality of this law. The results presented are average values from six samples taken approximately every two months of operation from the influent and permeate of the AnSMBR. 
Table 3 - Physicochemical characteristics of the influent and permeate from the AnSMBR.

\begin{tabular}{|c|c|c|c|}
\hline & $\begin{array}{c}\text { Feed wastewater } \\
\text { (Mean values) }\end{array}$ & $\begin{array}{c}\text { Permeate } \\
\text { (Mean values) }\end{array}$ & $\begin{array}{c}\text { Spanish law R.D. } \\
1620 / 2007 \\
\end{array}$ \\
\hline $\mathrm{pH}$ & $7.62 \pm 0.07$ & $7.22 \pm 0.15$ & \\
\hline Electrical Conductivity $25^{\circ} \mathrm{C}(\mathrm{mS} / \mathrm{cm})$ & $2.11 \pm 0.86$ & $2.47 \pm 0.23$ & 3 \\
\hline Total dissolved salts $(g / L)$ & $1.5 \pm 0.78$ & $1.798 \pm 0.14$ & \\
\hline \multicolumn{4}{|l|}{ Anions } \\
\hline Chloride $(m g / L)$ & $337 \pm 45.25$ & $307 \pm 46.7$ & \\
\hline Sulphate $(m g / L)$ & $63.5 \pm 14.57$ & $24.11 \pm 26.5$ & \\
\hline Hydroxyl & $<10$ & $<1$ & \\
\hline Carbonate $(m g / L)$ & $<10$ & $<10$ & \\
\hline Bicarbonate $(m g / L)$ & $651.5 \pm 531.04$ & $995.4 \pm 77.22$ & \\
\hline $\mathrm{N}-\mathrm{NO}_{3-}(\mathrm{mg} / \mathrm{L})$ & & $<1$ & \\
\hline Dissolved $\mathrm{P}(\mathrm{mg} / \mathrm{L})$ & $9.55 \pm 9.4$ & $12.6 \pm 4.11$ & \\
\hline \multicolumn{4}{|l|}{ Cations } \\
\hline Dissolved Calcium $(m g / L)$ & $54.5 \pm 22.2$ & $69.5 \pm 6.17$ & \\
\hline Dissolved Magnesium ( $\mathrm{mg} / \mathrm{L}$ ) & $32.3 \pm 28.1$ & $42.42 \pm 2.57$ & \\
\hline Dissolved Sodium ( $m g / L)$ & $301 \pm 115.9$ & $294.4 \pm 21.73$ & \\
\hline Dissolved Potassium $(m g / L)$ & $38.45 \pm 31.6$ & $50.36 \pm 3.59$ & \\
\hline $\mathrm{N}-\mathrm{NH}_{4}+(m g / L)$ & $55.4 \pm 8.6$ & $69.16 \pm 15.17$ & \\
\hline \multicolumn{4}{|l|}{ Micronutrients } \\
\hline Dissolved boron $(m g / L)$ & $0.14 \pm 0.1$ & $0.17 \pm 0.04$ & 0.5 \\
\hline Dissolved iron $(m g / L)$ & $0.18 \pm 0.08$ & $0.33 \pm 0.24$ & \\
\hline Dissolved Manganese $(\mathrm{mg} / \mathrm{L})$ & $0.03 \pm 0.02$ & $0.04 \pm 0.004$ & 0.2 \\
\hline Dissolved copper $(\mathrm{mg} / \mathrm{L})$ & $<0.05$ & $<0.05$ & 0.2 \\
\hline Dissolved Zinc $(\mathrm{mg} / \mathrm{L})$ & $<0.01$ & $<0.01$ & \\
\hline \multicolumn{4}{|l|}{ Secondary indexes } \\
\hline Sodium absorption ratio S.A.R ( $m$ eq/L) & $8.1 \pm 0.4$ & $6.86 \pm 0.56$ & 6 \\
\hline Suspended solids ( $m g / L$ ) & $1251 \pm 1378.8$ & $2.6 \pm 1.19$ & 20 \\
\hline Turbidity (NTU) & $1131.5 \pm 1383.8$ & $111.75 \pm 25.12$ & 10 \\
\hline
\end{tabular}

Most of the analyzed parameters were below the maximum admissible values. The concentration of all metals required by this law (Be, B, V, Cr, Mn, Co, Ni, Cu, As, $\mathrm{Se}, \mathrm{Mo}, \mathrm{Ca}, \mathrm{Pb}$ ) in all cases was below the limit value, and even below the detection limit. These results indicate that there is no significant contribution of industrial wastewater to the municipal wastewater, and therefore the possible use of this treated wastewater for agricultural irrigation will not cause problems of heavy metal accumulation in soil, plants and groundwater. 
The electrical conductivity of all the samples also presented values lower than the maximum limit value, although there was a slight increase in the permeate conductivity, which could be due to the increase in bicarbonate concentration due to the anaerobic treatment. In general, as salinity increases in the treated wastewater used for irrigation, the probability for certain soil, water, and crop problems increases. The concentration of suspended solids was also well below the limit value, fundamentally due to the membrane rejection. This low value of suspended solids could reduce the problem of clogging in sprinkler and drip irrigation systems. Nevertheless, the sodium adsorption ratio (SAR) in the influent $(8.1 \pm 0.4 \mathrm{meq} / \mathrm{L})$ was already higher than the limit value (6 meq/L), and it decreased in the permeate, obtaining an average value of $6.8 \pm 0.56$. Typically, the SAR of treated wastewater ranges from 4.5 to 7.9 [38]. Andrews et al. [15] showed that both the sodium adsorption ratio and salinity of the soil were significantly higher in the irrigated soil than in the non-irrigated soil.

The turbidity limit value is 10 NTU, however all the analyzed samples from the permeate showed a higher turbidity, with values of between 90 and 150 NTU, although these samples were transparent, with a suspended solid concentration of $2.6 \pm 1.2 \mathrm{mg} / \mathrm{L}$. Only the last sample analyzed had a turbidity value of $<0.5 \mathrm{NTU}$. In the methodology used for turbidity determination, it is necessary to shake the sample vigorously. It was observed that micro-bubbles / micro-foams were formed during the agitation process. These micro-bubbles could be responsible for the high turbidity of the effluent, although the suspended solid concentration of all permeate samples was below the limit.

The results showed that the microbiological analyses from the permeate samples met the limits required to be categorized as Quality 1 treated municipal wastewater, according to the Spanish law [37] (Table 4). 
Table 4 - Microbial quality of the influent and permeate from the AnSMBR

\begin{tabular}{|c|c|c|c|}
\hline & Influent & Permeate & $\begin{array}{c}\text { Limit value Spanish } \\
\text { Law R.D. } \\
\text { 1620/2007 }\end{array}$ \\
\hline E. coli & $\begin{array}{c}4 * 10^{6}-2 * 10^{7} \\
\mathrm{nmp} / 100 \mathrm{~mL}\end{array}$ & $42 \pm 48 \mathrm{cfu} / 100 \mathrm{~mL}$ & $100 \mathrm{cfu} / 100 \mathrm{~mL}$ \\
\hline Helminth eggs & $<1 \mathrm{egg} / 10 \mathrm{~L}$ & $<1 \mathrm{egg} / 10 \mathrm{~L}$ & $1 \mathrm{egg} / 10 \mathrm{~L}$ \\
\hline Legionella spp & presence in $100 \mathrm{~mL}$ & $\begin{array}{c}\text { not detected in } \\
100 \mathrm{~mL}(<100 \mathrm{cfu} / 100 \mathrm{~L}) \\
1 \mathrm{~L}(<100 \mathrm{cfu} / 1 \mathrm{~L})\end{array}$ & $1000 \mathrm{cfu} / 1 \mathrm{~L}$ \\
\hline $\begin{array}{l}\text { Legionella } p \\
\text { serogrup1 }\end{array}$ & not detected & not detected & \\
\hline $\begin{array}{l}\text { Legionella } p \\
\text { serogrup 2-15 }\end{array}$ & not detected & not detected & \\
\hline Salmonella spp & absent & absent in a $1 \mathrm{~L}$ & \\
\hline
\end{tabular}

Helminth eggs (including intestinal nematodes) in all the samples were below $1 \mathrm{egg} / 10 \mathrm{~L}$. The Escherichia coli count, taken in samples from the influent, had values of between $4 \times 10^{6}-2 \times 10^{7} \mathrm{nmp} / 100 \mathrm{~mL}$, while all the samples from the permeate were below the limit (100 cfu/100 mL), except for the last sample taken during the summer, which presented a value of $490 \mathrm{cfu} / 100 \mathrm{~mL}$. This high value could be due to the re-growth in the permeate storage tank, which is open to the atmosphere. This re-growth makes it necessary to carry out a proper design and control of the storage tank of the treated wastewater, in view of its application. Similar results have been reported by other authors with different tertiary treatment in the $E$. coli removal. Lonigro et al. [39] showed E. coli concentrations of $248 \mathrm{cfu} / 100 \mathrm{~mL}$ in the secondary effluent of a municipal WWTP tertiary treated through a sand filtration and then by ultrafiltration membrane (0.2 microns). De Sanctis et al. [40], using a Sequencing Batch Biofilter Granular Reactor followed by filtration sand, showed $E$. coli concentration in the effluent of $60 \mathrm{MPN} / 100 \mathrm{~mL}$. Salmonella is not only an 
indicator of fecal contamination but is also a serious human pathogen. In the present work, Salmonella spp, and Legionella spp were detected in the samples from the influent, while they were not detected in the permeate, being absent in all the analyzed samples. As for Legionella $p$, neither serogroup 1 or serogroups 2-15 were detected in any of the analyzed samples. Although the microbiology is different in each of the types of wastewater, the microbial quality in the tertiary effluent depends on the type of treatment performed.

Bacteriophages have been suggested as viral indicators, because they closely resemble enteric viruses in terms of their similar morphologies and overcome some of the limitations with current fecal indicators [41]. Although they are not included in the Spanish law, analysis of $\mathrm{F}+$ coliphages and somatic coliphages was also accomplished. The count of $\mathrm{F}+$ coliphages decreased from $53 \mathrm{pfu} / \mathrm{mL}$ to $2 \mathrm{pfu} / \mathrm{mL}$, and the somatic coliphages decreased from $6 \mathrm{pfu} / \mathrm{mL}$ a value $<1 \mathrm{pfu} / \mathrm{mL}$ in the permeate. Similar results were found in the literature consulted. De Sanctis et al. [40] showed somatic coliphages removal values ranging from $2.8 \pm 3.3 \times 10^{5} \mathrm{PFU} / 100 \mathrm{~mL}$ at the influent to $2.9 \pm 4.7 \times 10^{2} \mathrm{PFU} / 100 \mathrm{~mL}$ at the effluent, using Sequencing Batch Biofilter Granular Reactors followed by filtration sand. Purnell et al. [42], who used the activated sludge process followed by a ultrafiltration membrane, also showed a removal of $\mathrm{F}+$ coliphages, reaching a concentration in the effluent of $<1 \mathrm{PFU} / 100$ $\mathrm{mL}$.

The results have shown that the anaerobic treatment of municipal wastewater in a membrane bioreactor allows us to obtain an effluent that meets the Spanish law for the highest quality required in agricultural irrigation, without requiring other polishing treatments. The process obtained an effluent in which both the physical and microbiological parameters directly related to human health were below the established limits. 
However, more studies are needed, analyzing samples with the periodicity established in the law, in order to ensure the quality of the regenerated wastewater and the elimination of any risk to human health. Also, another important aspect to be considered, is an accurate study of the energy consumption of this type of AnMBR reactors. In these processes, the economic impact derives from the lower energy consumption in the treatment of wastewater and the agricultural use of treated water.

As an average and for a typical situation in the Mediterranean basin, energy consumption can be reduced from 0.4 to $0.25 \mathrm{kWh} / \mathrm{m}^{3}[7]$ and the treated water can reach a market value up to $0.15 € / \mathrm{m}^{3}$. For a population of 50,000 equivalent inhabitants, the total saving can reach $450,000 € / y$. As a consequence of the improvement in the quality of the membranes and the reduction of their implementation cost, the payback time of the facility could be reduced from the current 5 years to 3 years in the immediate future.

\section{Conclusions}

AnSMBR is a viable technology for the treatment of municipal wastewater at ambient temperature $\left(20^{\circ} \mathrm{C}-26^{\circ} \mathrm{C}\right)$. A COD elimination efficiency greater than $89 \%$ can be achieved due to the membrane, especially in wastewater with a high pCOD content. The activity decreases markedly when the temperature drops below $15^{\circ} \mathrm{C}$, and then the biogas production is almost negligible. The temperature is a fundamental variable, and a rapid temperature decrease does not facilitate the acclimation of the sludge to psychrophilic conditions. The effluent complies with the Spanish law for agricultural irrigation, fitting into the most restrictive category. 


\section{Acknowledgements}

This work was funded by CADAGUA and supported by ESAMUR, Entidad de Saneamiento y Depuración de la Región de Murcia. Thiago Antonio would like to thank the Conselho Nacional de Desenvolvimento Científico e Tecnológico (CNPq, NationalCouncil for the Scientific and Technological Development, Brazil), for his PhD scholarship.

\section{References}

[1] M. Farhadkhani, M. Nikaeen, G. Yadegarfar, M. Hatamzadeh, H. Pourmohammadbagher, Z. Sahbaei, H.R. Rahmani, Effects of irrigation with secondary treated wastewater on physicochemical and microbial properties of soil and produce safety in a semi-arid area, Water Res. 144 (2018) 356-364. doi:10.1016/j.watres.2018.07.047.

[2] D.W. Gao, Q. Hu, C. Yao, N.Q. Ren, Treatment of domestic wastewater by an integrated anaerobic fluidized-bed membrane bioreactor under moderate to low temperature conditions, Bioresour. Technol. 159 (2014) 193-198. doi:10.1016/j.biortech.2014.02.086.

[3] G. Chhipi-Shrestha, M. Rodriguez, R. Sadiq, Selection of sustainable municipal water reuse applications by multi-stakeholders using game theory, Sci. Total Environ. 650 (2019) 25122526. doi:10.1016/j.scitotenv.2018.09.359.

[4] X. Song, W. Luo, F.I. Hai, W.E. Price, W. Guo, H.H. Ngo, L.D. Nghiem, Resource recovery from wastewater by anaerobic membrane bioreactors: Opportunities and challenges, Bioresour. Technol. 270 (2018) 669-677. doi:10.1016/J.BIORTECH.2018.09.001.

[5] J. Wan, J. Gu, Q. Zhao, Y. Liu, COD capture: A feasible option towards energy self-sufficient domestic wastewater treatment, Sci. Rep. 6 (2016) 1-9. doi:10.1038/srep25054.

[6] R. Watanabe, Y. Nie, S. Wakahara, D. Komori, Y.-Y. Li, Investigation on the response of anaerobic membrane bioreactor to temperature decrease from $25^{\circ} \mathrm{C}$ to $10{ }^{\circ} \mathrm{C}$ in sewage $\begin{array}{lllll}\text { treatment, } & \text { Bioresour. } & \text { Technol. } & 243 & \text { (2017) }\end{array}$ doi:10.1016/J.BIORTECH.2017.07.001.

[7] Z. Lei, S. Yang, Y. Li, W. Wen, X.C. Wang, R. Chen, Application of anaerobic membrane bioreactors to municipal wastewater treatment at ambient temperature: $A$ review of achievements, challenges, and perspectives, Bioresour. Technol. 267 (2018) 756-768. doi:10.1016/j.biortech.2018.07.050.

[8] C. Shin, J. Bae, Current status of the pilot-scale anaerobic membrane bioreactor treatments of domestic wastewaters: A critical review, Bioresour. Technol. 247 (2018) 1038-1046. doi:10.1016/J.BIORTECH.2017.09.002.

[9] M.D. Seib, K.J. Berg, D.H. Zitomer, Low energy anaerobic membrane bioreactor for municipal wastewater treatment, J. Memb. Sci. $514 \quad$ (2016) 450-457. doi:10.1016/J.MEMSCI.2016.05.007. 
[10] H. Ozgun, R.K. Dereli, M.E. Ersahin, C. Kinaci, H. Spanjers, J.B. Van Lier, A review of anaerobic membrane bioreactors for municipal wastewater treatment: Integration options, limitations and expectations, Sep. Purif. Technol. $118 \quad$ (2013) 89-104. doi:10.1016/j.seppur.2013.06.036.

[11] E. Marti, H. Monclús, J. Jofre, I. Rodriguez-Roda, J. Comas, J.L. Balcázar, Removal of microbial indicators from municipal wastewater by a membrane bioreactor (MBR), Bioresour. Technol. 102 (2011) 5004-5009. doi:10.1016/j.biortech.2011.01.068.

[12] J.P.S. Sidhu, K. Sena, L. Hodgers, A. Palmer, S. Toze, Comparative enteric viruses and coliphage removal during wastewater treatment processes in a sub-tropical environment, Sci. Total Environ. 616-617 (2018) 669-677. doi:10.1016/j.scitotenv.2017.10.265.

[13] G. Ganjegunte, A. Ulery, G. Niu, Y. Wu, Effects of treated municipal wastewater irrigation on soil properties, switchgrass biomass production and quality under arid climate, Ind. Crops Prod. 99 (2017) 60-69. doi:10.1016/j.indcrop.2017.01.038.

[14] I. Rekik, Z. Chaabane, A. Missaoui, A.C. Bouket, L. Luptakova, A. Elleuch, L. Belbahri, Effects of untreated and treated wastewater at the morphological, physiological and biochemical levels on seed germination and development of sorghum (Sorghum bicolor (L.) Moench), alfalfa (Medicago sativa L.) and fescue (Festuca arundinacea Schreb.), J. Hazard. Mater. 326 (2017) 165-176. doi:10.1016/j.jhazmat.2016.12.033.

[15] D.M. Andrews, T. Robb, H. Elliott, J.E. Watson, Impact of long-term wastewater irrigation on the physicochemical properties of humid region soils: "The Living Filter" site case study, Agric. Water Manag. 178 (2016) 239-247. doi:10.1016/j.agwat.2016.10.001.

[16] M. Adrover, E. Farrús, G. Moyà, J. Vadell, Chemical properties and biological activity in soils of Mallorca following twenty years of treated wastewater irrigation, J. Environ. Manage. 95 (2012) S188-S192. doi:10.1016/j.jenvman.2010.08.017.

[17] S. Bedbabis, D. Trigui, C. Ben Ahmed, M.L. Clodoveo, S. Camposeo, G.A. Vivaldi, B. Ben Rouina, Long-terms effects of irrigation with treated municipal wastewater on soil, yield and olive oil quality, Agric. Water Manag. 160 (2015) 14-21. doi:10.1016/j.agwat.2015.06.023.

[18] APHA, Standard Methods for the Examination of Water and Wastewater, 2005. doi:10.2105/AJPH.51.6.940-a.

[19] Reference document Orden SCO/778/229 March 17, Alternative methods for the microbiological analysis of water, BOE March 31. (2009).

[20] Reference document draft CEN standard: soil, sludge and treated biowastes. Detection and enumeration of viable helminth ova in sludge soils and biowastes. Flotation method., Eur. Comm. Stand. (2008).

[21] UNE-EN ISO 11731, Water quality. Enumeration of Legionella, AENOR. (2017).

[22] UNE-EN ISO 19250, Water quality. Enumeration of Salmonella spp, AENOR. (2013).

[23] UNE-EN ISO 10705-2, Water quality. Detection, and enumeration of bacteriophages-part 2: enumeration of somatic coliphages AENOR, AENOR. (2002).

[24] UNE-EN ISO 10705-1, Water quality. Detection and enumeration of bacteriophages. Part 1: Enumeration of F-specific RNA bacteriophages., AENOR. (2002).

[25] H. Ozgun, Y. Tao, M.E. Ersahin, Z. Zhou, J.B. Gimenez, H. Spanjers, J.B. van Lier, Impact of 
Temperature on Feed-flow Characteristics and Filtration Performance of an Upflow Anaerobic Sludge Blanket Coupled Ultrafiltration Membrane Treating Municipal Wastewater, Water Res. 83 (2015) 71-83. doi:10.1016/j.watres.2015.06.035.

[26] J. Gouveia, F. Plaza, G. Garralon, F. Fdz-Polanco, M. Peña, A novel configuration for an anaerobic submerged membrane bioreactor (AnSMBR). Long-term treatment of municipal wastewater under psychrophilic conditions, Bioresour. Technol. 198 (2015) 510-519. doi:10.1016/j.biortech.2015.09.039.

[27] J. Gouveia, F. Plaza, G. Garralon, F. Fdz-Polanco, M. Peña, Long-term operation of a pilot scale anaerobic membrane bioreactor (AnMBR) for the treatment of municipal wastewater under psychrophilic conditions, Bioresour. Technol. $185 \quad$ (2015) 225-233. doi:10.1016/j.biortech.2015.03.002.

[28] G. Lettinga, S. Rebac, G. Zeeman, Challenge of psychrophilic anaerobic wastewater treatment, Trends Biotechnol. 19 (2001) 363-370. doi:10.1016/S0167-7799(01)01701-2.

[29] P. Dolejs, O. Ozcan, R. Bair, J. Ariunbaatar, J. Bartacek, P.N.L. Lens, D.H. Yeh, Effect of psychrophilic temperature shocks on a gas-lift anaerobic membrane bioreactor (GI-AnMBR) treating synthetic domestic wastewater, J. Water Process Eng. 16 (2017) 108-114. doi:10.1016/j.jwpe.2016.12.005.

[30] S. Perry, R.H. Perry, D.W. Green, J.O. Maloney, Perry's chemical engineers' handbook, seventh, McGraw-Hill, New York, 1997.

[31] K.M. Wang, D. Cingolani, A.L. Eusebi, A. Soares, B. Jefferson, E.J. McAdam, Identification of gas sparging regimes for granular anaerobic membrane bioreactor to enable energy neutral municipal wastewater treatment, J. Memb. Sci. 555 (2018) 125-133. doi:10.1016/j.memsci.2018.03.032.

[32] X. Mei, Z. Wang, Y. Miao, Z. Wu, Recover energy from domestic wastewater using anaerobic membrane bioreactor: Operating parameters optimization and energy balance analysis, Energy. 98 (2016) 146-154. doi:10.1016/j.energy.2016.01.011.

[33] X. Li, J. Li, J. Wang, H. Wang, B. He, H. Zhang, W. Guo, H.H. Ngo, Experimental investigation of local flux distribution and fouling behavior in double-end and dead-end submerged hollow fiber membrane modules, J. Memb. Sci. 453 (2014) 18-26. doi:10.1016/j.memsci.2013.10.052.

[34] J. Ferrer, R. Pretel, F. Durán, J.B. Giménez, A. Robles, M. V. Ruano, J. Serralta, J. Ribes, A. Seco, Design methodology for submerged anaerobic membrane bioreactors (AnMBR): A case study, Sep. Purif. Technol. 141 (2015) 378-386. doi:10.1016/j.seppur.2014.12.018.

[35] Q. Wang, H. Zeng, Z. Wu, J. Cao, Impact of sodium hypochlorite cleaning on the surface properties and performance of PVDF membranes, Appl. Surf. Sci. 428 (2018) 289-295. doi:10.1016/j.apsusc.2017.09.056.

[36] F. Gao, J. Wang, H. Zhang, Y. Zhang, M.A. Hang, Effects of sodium hypochlorite on structural/surface characteristics, filtration performance and fouling behaviors of PVDF membranes, J. Memb. Sci. 519 (2016) 22-31. doi:10.1016/j.memsci.2016.07.024.

[37] BOE MARM, Real Decreto 1620/2007, de 7 de diciembre, por el que se establece el régimen jurídico de la reutilización de las aguas depuradas, 2007.

[38] Z. Muyen, G.A. Moore, R.J. Wrigley, Soil salinity and sodicity effects of wastewater irrigation in 
South East Australia, Agric. Water Manag. $99 \quad$ (2011) 33-41. doi:10.1016/j.agwat.2011.07.021.

[39] A. Lonigro, P. Rubino, V. Lacasella, N. Montemurro, Faecal pollution on vegetables and soil drip irrigated with treated municipal wastewaters, Agric. Water Manag. 174 (2016) 66-73. doi:10.1016/j.agwat.2016.02.001.

[40] M. De Sanctis, G. Del Moro, S. Chimienti, P. Ritelli, C. Levantesi, C. Di laconi, Removal of pollutants and pathogens by a simplified treatment scheme for municipal wastewater reuse in agriculture, Sci. Total Environ. 580 (2017) 17-25. doi:10.1016/j.scitotenv.2016.12.002.

[41] G.G.R.V. Vergara, S.G. Goh, S. Rezaeinejad, S.Y. Chang, M.D. Sobsey, K.Y.H. Gin, Evaluation of FRNA coliphages as indicators of human enteric viruses in a tropical urban freshwater catchment, Water Res. 79 (2015) 39-47. doi:10.1016/j.watres.2015.04.022.

[42] S. Purnell, J. Ebdon, A. Buck, M. Tupper, H. Taylor, Removal of phages and viral pathogens in a full-scale MBR: Implications for wastewater reuse and potable water, Water Res. 100 (2016) 20-27. doi:10.1016/j.watres.2016.05.013. 
CHAPTER 8 | Anaerobic submerged membrane bioreactor AnSMBR operating at ambient temperature 



\section{Conctusjons}

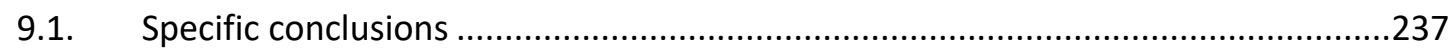

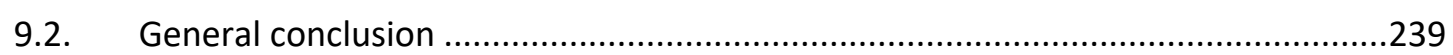





\subsection{Specific conclusions}

Following are stated some specific results obtained from this research.

\section{Permeate:}

- The ultrafiltration membranes can recover the totality of the particulate matter from the primary wastewater and generate a high-quality permeate containing only soluble COD and nutrients.

- Operating parameters such as permeate flux and gas scouring has no influence over the permeate quality, which remarks the flexibility of the system. On another hand, the concentrations of soluble compounds in the inlet wastewater, and inside the membrane tank, are affecting factors.

- Depending on the organic and nutrients load in the inlet wastewater, the permeate can fulfil the required composition for being directly released into the water bodies, for being used as fertilizer or treated at a low temperature anaerobic process with high specific methane yield due to the readily biodegradable compounds.

- A high-quality permeate is produced by the AnSMBR with chemical and microbiological parameters below the limits required for agricultural use. The permeate quality is sensitive to the rate of organic biodegradation inside the AnSMBR, therefore the effluent COD increases with low temperature. However, the COD concentrations were kept between 150 and 100mg/L.

\section{Solids recovery:}

- The design of the membrane tank used throughout the experiments, with the filtration section separated from the sedimentation section, allows for the recovering of particulate matter with a concentration up to $45 \mathrm{~g} / \mathrm{L}$ in terms of TS, whereas the membrane module operates with lower solids concentrations. 
- The specific methane yield of recovered solids is according to the expected to a primary sludge, situated between 280 and $350 \mathrm{mLCH}_{4} / \mathrm{gSV}_{\text {fed, }}$ even when different antifouling strategies are applied, therefore, showing no noticeable effect over the biodegradability. Therefore, gas scouring, coagulant addition (between 1.5 and 15 mg/L dissolution), $\mathrm{NaClO}$ addition (between 250 and 1000 ppm dissolution) and citric acid addition (1\% dissolution) have no negative influence over the solid's biodegradability.

- Long-term operations with low transmembrane pressures are feasible with continuous or periodical purges of concentrated solids containing high concentrations of COD, between 11,000 and $30,000 \mathrm{mg} / \mathrm{L}$.

- The gas scouring recirculation avoids the organic matter to be oxidized by fresh air, thus potentiating the available carbon content for anaerobic digestion.

- The carbon recovery allied to the intermittent gas scouring (40 s on each 3.5 min off, with $97 \mathrm{~m} / \mathrm{h}$ of superficial gas velocity) as fouling control allows the DMF process to operate at long-term with a positive energy balance. A simplified energy study reveals that about $0.19 \mathrm{kWh} / \mathrm{m}^{3}$ can be produced against 0.15 $\mathrm{kWh} / \mathrm{m}^{3}$ of consumption by the DMF process.

\section{Membrane behavior:}

- The ultrafiltration membrane modules are robust equipment with high resilience in supporting several operating conditions at long-term processes.

- In contrast, the long-term operations are conditioned to the antifouling strategies applied on the membrane module. Nevertheless, intermittent gas scouring combined with periodical purge are strong operating procedures to maintain low transmembrane pressures without damaging the membrane module. 
- By operating with transmembrane pressures below 400 mbar, the filtration process can be performed with high efficiency in terms of solid recovery and quality of produced water.

- The irreversible fouling was the most important contributor in diminishing the membrane permeability at long-term operation. However, the in situ or ex-situ chemical cleaning with $\mathrm{NaClO}$ showed high efficiency, evidencing that most of the internal and external fouling was caused by organic compounds. A combined cleaning with $\mathrm{NaClO}$ and citric acid can also recover the membrane permeability by eliminating organic matter and inorganic salts from the membrane fibers.

\subsection{General conclusion}

The results in this present thesis evidence that the direct membrane filtration applied for the up concentration of municipal wastewater is a feasible operation with remarkable results regarding both carbon recovery potential, process control and high-quality produced water. The literature about the advantages of using the DMF as a potential carbon capturer technology is still scarce and a very few researchers have addressed this technology at long-term and pilot-scale. This work contributes to encourage the wastewater treatment stakeholders to consider a readjustment of the conventional WWTP in order to overcome the global demanding for sustainable water and wastewater treatment. 

Futule perspecidves

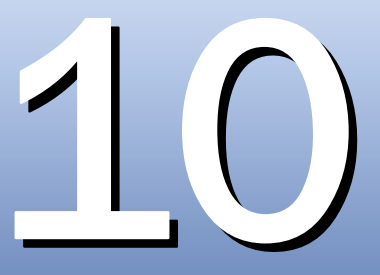



The direct membrane filtration for the municipal wastewater treatment is a feasible operation with real potential for being a replacing process for the conventional wastewater treatments that demand a high energy consumption. Despite the overall results of this present thesis, the DMF process still needs further improvements before being accepted and used in full-scale. Some of these improvements are following listed:

- Further experiments in pilot-scale with different types of urban wastewaters with domestic and industrial compounds would attest the process reliability before using in large-scale.

- A statistical study is still necessary for stating a numerical significance between the fundamental variables for the fouling control and, therefore, establishing a better combination of antifouling strategies.

- The design of the membrane tank can be improved in order to avoid the suspension of particulate matter and, at the same, ensures the up concentration of settled solids.

- Other chemicals and different concentrations should be studied for the ex-situ and in situ membrane cleaning in order to eliminate reversible and irreversible fouling without damaging the membrane fibers.

- The filtration cycles can be optimized in order to reduce the fouling formation over the membrane. Studies should verify if a higher frequency of backwash would enhance the filtration performance without losing of water productivity.

- The use of coagulant should be considered for some cases in which the inlet wastewater presents high suspended solids or colloidal particles. However, the effect over the membrane material needs to be previously studied. 
- Since the membrane purchasing is still a matter of concern, membrane lifespan analysis should be performed, and, for the DMF, the operating conditions should also reflect this real constraint.

- Large-scale experiments in long-term should be considered for assessing constraints of the DMF other than the already studied in this thesis. The longterm experiments in this research have been carried out up to 54 days, which may be considered short-term when compared with full-scale operations.

- The membrane fouling is a real concern for a very long-term operation. Application of other antifouling strategies are welcome. The literature presents different and creative solutions for dealing with the fouling issue, however, the operational cost must be put into consideration.

- The process systems of control can he improved in order to automatically maintain the filtration pressures under the safety limit, therefore, increasing the gas scouring velocity or reducing the filtration flux, or changing any other parameter of control according to the plant setup.

- Membrane materials should be studied since its characteristics totally influences both the reversible and the irreversible fouling.

- A combined DMF + activated sludge process, is also a feasible option for treating the permeate stream with high content of soluble COD. The energy production by the DMF stage can offset the overall energy consumption. Further studies may consider this combined process as an option.

- In the next years, the membrane-based processes would be prompted due to the stringent legislations. The anaerobic submerged membrane bioreactors are a feasible option for the high-quality water production, however more efforts should be made towards the carbon recovery at low temperature. 
CHAPTER 10 | Future perspectives 

Cusrjeujuss V/itae

11 



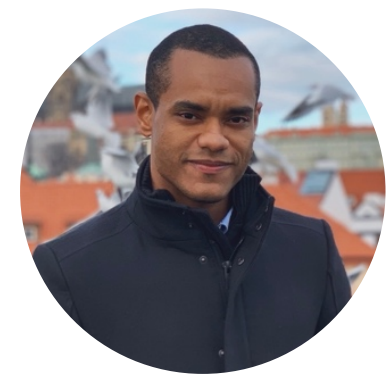

thiagoantonio.br@gmail.com

+34 684019588

Valladolid, España

\section{Chemical Engineer with doble degree}

\author{
Thiago Antonio do Nascimento
}

University of Valladolid (Spain) | Federal University of Pernambuco (Brazil)

\section{PUBLICATIONS IN INTERNATIONAL JOURNALS}

- T.A. Nascimento, M.P. Miranda, Continuous municipal wastewater upconcentration by direct membrane filtration, considering the effect of intermittent gas scouring and threshold flux determination, J. Water Process Eng. 39 (2021). doi:10.1016/j.jwpe.2020.101733.

- T.A. Nascimento, F. Fdz-Polanco, M. Peña, Membrane-Based Technologies for the Up-Concentration of Municipal Wastewater: A Review of Pretreatment Intensification, Sep. Purif. Rev. 49 (2020) 1-19.

- $\quad$ M. Peña, T. do Nascimento, J. Gouveia, J. Escudero, A. Gómez, A. Letona, J. Arrieta, F. Fdz-Polanco, Anaerobic submerged membrane bioreactor (AnSMBR) treating municipal wastewater at ambient temperature: Operation and potential use for agricultural irrigation, Bioresour. Technol. 282 (2019) 285-293. doi:10.1016/j.biortech.2019.03.019.

- T.A. Nascimento, F.R. Mejía, F. Fdz-Polanco, M. Peña, Improvement of municipal wastewater pretreatment by direct membrane filtration, Environ. Technol. 38 (2017) 2562-2572. doi:10.1080/09593330.2016.1271017.

- T.A. Nascimento, M.P. Miranda, Control strategies for the long-term operation of direct membrane filtration of municipal wastewater, J. Environ. Chem. Eng. (2021). doi:10.1016/j.jece.2021.105335.

\section{PARTICIPATION IN CONGRESS}

- T.A. Nascimento, M.P. Miranda, Filtración direct con membranas: una alternativa para la concentración de la materia orgánica del agua residual urbana, VII Jornada sobre Bioreatores de Membrana. 16 oct 2019, Barcelona, Spain (Oral presentation).

- T.A. Nascimento, M.P. Miranda, Filtración direct con membranas: alternativa para una depuradora autosiuficiente, $X$ Reunión de Jóvenes Investigadores Iberoamericanos. 31 mar 2017, Tordesillas, Spain (Poster).

- T.A. Nascimento, M.P. Miranda, Direct membrane filtration of municipal wastewater, XII Latin American Workshop and Symposium on Anerobic Digestion. 23-27 oct 2016, Cuzco, Peru (Oral presentation).

- T.A. Nascimento, M.P. Miranda, Jornadas de Doctorandos en Ing. Química y Ambiental, años IV, V, VI y VII. 2016 - 2019. Valladolid, Spain (Posters and Oral presentations). 
- Comunicación y soft Skills. 20 nov 2020. Valladolid, Spain (8h).

- Eficiencia y viabilidad de nuevas tecnologias en procesos de tratamiento de aguas residuales. 13 mar 2020. Valladolid, Spain (10h).

- Curso básico de análisis por cromatografía de gases. 14 and 21 feb 2019. Valladolid, Spain (6h).

- Curso básico de prevención de riesgos laborales. 12-19 feb 2018. Valladolid, Spain (30h).

- Curso de oratoria, inteligencia emocional y programación neuroliguistica (PNL). 24 and 31 oct | 07 nov 2017. Valladolid, Spain (6h).

- Project manegement. Finalization: 04 mar 2018. Online (45h).

- Principles of sustainability and innovative technologies. Finalization: 06 aug 2017. Online (45h).

- Biotecnología de microalgas. 08-12 may 2017. Valladolid, Spain (10h) 


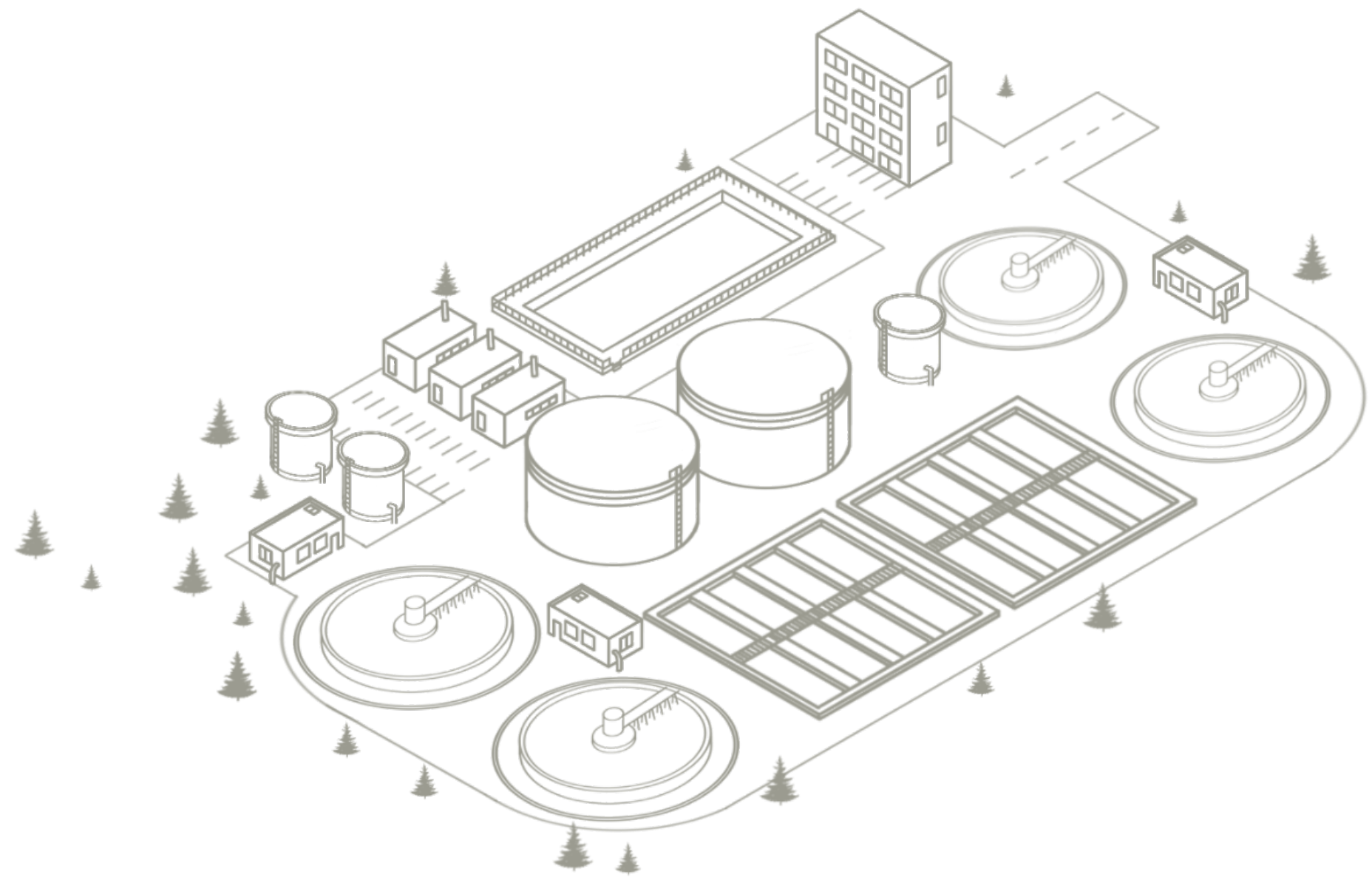

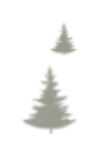

